



\section{CONTRIBUTIONS FROM THE ARNOLD ARBORETUM OF HARVARD UNIVERSITY}

A publication issued at irregular intervals by the Arnold Arboretum of Harvard University.

The issues of this publication can be obtained from the Arnold Arboretum, Jamaica Plain, Mass., U. S. A. All correspondence relating to exchange for publications of institutions and societies should be addressed to the Librarian, Arnold Arboretum, Jamaica Plain, Mass., U. S. A.

No. I. The Hypodermataceae of Conifers. By G. D. Darker. Pp. 1-131, plates 1-27. June 15, $1932 \ldots \ldots$. . \$3.00

No. II. Taxonomy and Geographical Distribution of the Genus Milesia. By J. H. Faull. Pp. 1-138, 2 text fig. ures, plates $1-9$. October $1,1932 \ldots \ldots \ldots \ldots \ldots \ldots \ldots$........ $\$ 3$

No. III. Studies in the Boraginaceae. 1. The Allocarya Section of Plagiobothrys in the Western United States. 2. Notes on Various Borages of the Western United States. By Ivan M. Johnston. Pp. 1-102. Decem-

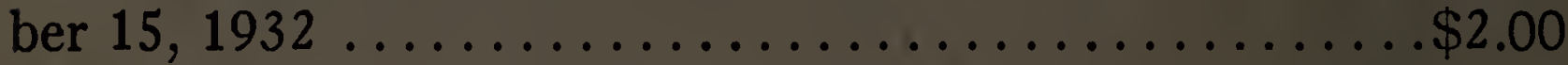

No. IV. Ligneous Plants Collected for the ARnold Arboretum IN North QueEnsland By S. F. Kajewsin IN 1929. By Cyril T. White. Pp. 1-113, 4 text figures, plates 1-9. April 1, $1933 \ldots \ldots \ldots \ldots \ldots \ldots \ldots \ldots \ldots \ldots \ldots$

No. V. The Flora of Barro Colorado Island, Panama. By Paul C. Standley. Pp. 1-178, plates 1-21, map. October

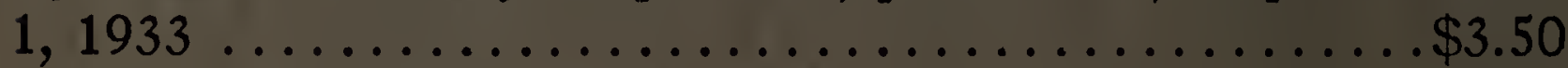

No. VI. Phytogeographic Studies in the Peace and Upper Liard River Regions, Canada. With a Catalogue of the Vascular Plants. By Hugh M. Raup. Pp. 1-230, plates $1-9$, map. February $15,1934 \ldots \ldots \ldots \ldots \ldots 2.50$

No. VII. The Beech Bark Disease; A Nectria Disease of Fagus following Cryptococcus Fagi (Baer.). By John Ehrlich. Pp. 1-104, plates 1-9. September 29, 1934 . \$2.00

No. VIII. An Enumeration of Plants Collected in Sumatra by W. N. and C. M. Bangham. By E. D. Merrill. Pp. 1-178, plates 1-14. August 25, $1934 \ldots \ldots \ldots \ldots$. . \$2.50

No. IX. The Species of Tradescantia Indigenous to the United States. By Edgar Anderson and Robert $E$. Woodson. Pp. 1-132, plates 1-12. August 30, 1935 ..\$2.25 
THE SPECIES OF TRADESCANTIA INDIGENOUS

TO THE UNITED STATES 

CONTRIBUTIONS FROM THE ARNOLD ARBORETUM OF HARVARD UNIVERSITY

IX

\section{THE SPECIES OF TRADESCANTIA INDIGENOUS TO THE UNITED STATES}

BY

EDGAR ANDERSON and ROBERT E. WOODSON

WITH TWELVE PLATES

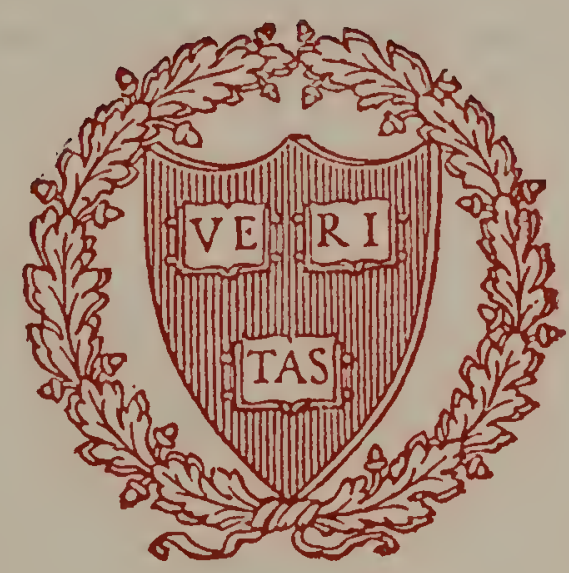

PUBLISHED BY

THE ARNOLD ARBORETUM OF HARVARD UNIVERSITY

JAMAICA PLAIN, MASS., U.S.A.

1935 
Contributions from the Arnold Arboretum OF HARVARD UNIVERSITY

No. IX, pp. 1-132, plates 1-12

Issued August 30th, 1935

Printed on Worthy Permanent Book Paper by Eliot Press, Inc.

Boston, Massachusetts, U.S.A. 
To

C. D. Darlington

AND

KARL SAX

WHOSE INTEREST IN THE CHROMOSOMES OF

TRADESCANTIA LED US TO CONSIDER

THE SPECIES OF THAT GENUS 

TABLE OF CONTENTS

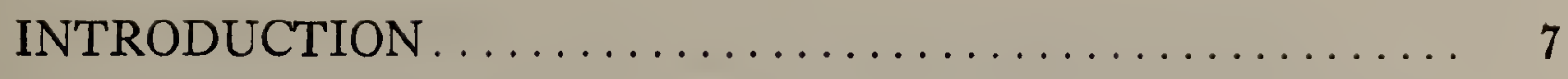

TAXONOMIC HISTORY ........................ 8

GROSS MORPHOLOGY ......................... 13

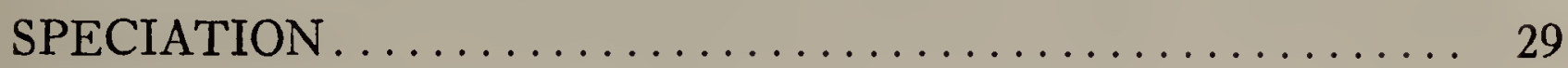

HYBRIDIZATION . . . . . . . . . . . . . . . . . . . . . 31

STUDY MATERIAL $\ldots \ldots \ldots \ldots \ldots \ldots \ldots \ldots \ldots \ldots \ldots, 43$

TAXONOMY $\ldots \ldots \ldots \ldots \ldots \ldots \ldots \ldots \ldots \ldots \ldots \ldots, 44$

Key to the Species............................ 45

Descriptions, Citations of Synonyms and Specimens..... 48

Excluded Species........................... 117

List of Exsiccatae . . . . . . . . . . . . . . . . . . . . 119

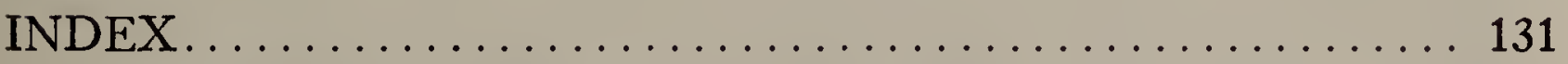

PLATES

I. Root Systems of Representative Species.

II. Leaf Surfaces of Representative Species.

III. Flower Buds of Representative Species.

IV. Calyces of Tradescantia.

V. Calyces of Tradescantia and Callisia.

VI. Calycine Pubescence of Representative Species.

VII. Seeds of Representative Species.

VIII. Tradescantia Ernestiana E. Anders. \& Woods.

IX. Tradescantia Tharpil E. Anders. \& Woods.

X. Tradescantia longipes E. Anders. \& Woods.

XI. Tradescantia paludosa E. Anders. \& Woods.

XII. Tradescantia ozarkana E. Anders. \& Woods. 



\section{THE SPECIES OF TRADESCANTIA INDIGENOUS TO THE UNITED STATES}

\section{INTRODUCTION}

Few genera of flowering plants without direct economic importance have been the subjects of more varied and sustained biological investigation than has the genus Tradescantia. From the aspects of taxonomy, physiology, cytology, and genetics the genus has attracted the attention of many botanists. One biologist has gone so far as to declare in a memoir ${ }^{1}$ commemorating the centennial of the discovery of the living nucleus that a history of research on Tradescantia is tantamount to a history of cytology!

Recent years have seen much interest aroused in the combination of cytology and genetics for the investigation of certain phases of evolutionary processes. It is not surprising that here also Tradescantia has come to the fore as an object of experimentation and observation, since the genus has much to recommend it for cyto-genetic studies. It grows easily from seeds or transplants and can withstand all sorts of mistreatment. It has a long blooming period and artificial pollinations are not difficult to make. The chromosomes are large (they can sometimes be counted under low power of the compound microscope) and are readily studied in smear preparations. Both tetraploid and diploid species and varieties occur in nature, and are available for genetical analysis. Yet fundamental conclusions as to the evolutionary importance of the cyto-genetic phenomena will not be possible until they can be viewed against a background of intensive morphological and taxonomical research, which has been singularly neglected in this genus.

With the multiple needs of taxonomy, cytology, and genetics in mind, the results of an attempt to revise the native species of Tradescantia occurring north of Mexico are presented in this paper. Reasons for restricting the scope of the revision to the species indigenous to the United States are several and cogent. It is upon this group of species, fairly frequent in cultivation and accessible in the field, that the recent cytological and genetical investigations are being directed in the main. From a strictly

${ }^{1}$ Küster, E. Hundert Jahre Tradescantia. Jena, 1933. 
taxonomic point of view, also, this restriction of attention is justified not only because the group under consideration is the typical element, since $T$. virginiana $L$. must be accepted as the type species, but because morphologically the species indigenous to the United States, with the exception of $T$. pinetorum Greene and $T$. micrantha Torr. which have close Mexican relatives, fall into very distinct groups of affinity which are fortunately limited in distribution to the geographical region chosen. Finally, the species of Tradescantia native to Mexico, the Antilles, and Central and South America are yet so insufficiently represented in our herbaria and inaccessible in the field that a satisfactory monographic treatment of them appears to be precluded for the present. It is inevitable that the study of additional herbarium specimens, increased knowledge of the plants in the field, and particularly the wide-spread investigation of the genus from the cyto-genetic standpoint should materially alter our present interpretations.

\section{TAXONOMIC HISTORY}

Although from the nomenclatural standpoint the genus Tradescantia dates from the publication of $T$. virginiana $\mathrm{L}$. in 1753 , plants of several species from the Atlantic seaboard of what is now the United States were growing in European gardens from a much earlier date. The first published account of the genus appears to have been in the appendix of Caspar Bauhin's 'Pinax' in 1623 under Allium sive Moly Virginianum, a Latin description which possibly indicates $T$. virginiana $L$. Bauhin ${ }^{1}$ related that he had seen the plant growing in a garden at Basle in 1622. In 1629 Parkinson's 'Paradisi in sole' included an account of similar plants called Phalangium Ephemerum Virginianum Iohannis Tradescant: "the soon-fading Spider-wort of Virginia, or Tradescant his Spider-wort." Parkinson" wrote: "This Spider-wort is of late knowledge, and for it the Christian world is indebted into that painfull industrious searcher, and louer of all natures varieties, Iohn Tradescant (sometimes belonging to the right Honourable Lord Robert Earle of Salisbury, Lord Treasurer of England in his time, and then vnto the right Honourable the Lord Wotton at Canterbury in Kent, and lastly vnto the late

${ }^{1}$ Pinax, 520 (1623).

${ }^{2}$ Parad. 152 (1629). 
Duke of Buckingham) who first receiued it of a friend, that brought it out of Virginia. ."

The popular name "Spiderwort" was explained by Sir William Hooker ${ }^{1}$ as follows: "Under the name Spiderwort, the old Botanists arranged plants of very different genera: the name is said to have arisen from the supposed efficacy of some of these plants, in curing the bite of a kind of spider, called Phalangium; not the Phalangium of Linnaeus, which is known to be perfectly harmless, under this name Parkinson minutely describes it; he mentions also, how he first obtained it."

Concerning John Tradescant, Lindley ${ }^{2}$ quoted Sir James Smith to the effect that he was a Hollander, having settled in England sometime prior to 1620 . Tradescant is reported to have been one of the very first in England to cultivate exotic plants. $\mathrm{He}$ travelled extensively, as far as Russia and Algeria, returning with plants and other natural curiosities from his excursions. About the year 1629 he became head gardener to Charles I. Meanwhile, however, he maintained his own establishment at Lambeth. "Tradescant's Museum," or "Ark," became very famous as a collection of natural rarities, and from a catalogue published in 1656, entitled "Museum Tradescantianum" appears to have contained not only plants, for which an index in English and Latin was included, but birds, quadrupeds, fish, shells, insects, minerals, warlike instruments, native utensils, coins, medals, etc. His son is said to have visited Virginia, returning with several new plants, among them the original Tradescantia. Upon the owner's death, the "Museum Tradescantianum" was bequeathed to Mr. Elias Ashmore, the founder of the Ashmolean Museum at Oxford. It is said that John Tradescant's tomb, an elaborate structure, still exists in Lambeth churchyard.

The first recognisable illustration of a Tradescantia would appear to be that published by Morison ${ }^{3}$ in 1699 as Ephemerum phalangioides tripetalon Virginianum gramineum. It seems to be more similar to $T$. canaliculata Raf. than to any other species. In 1700 , Tournefort ${ }^{4}$ also illustrated a tradescantia flower, listing

${ }^{1}$ Bot. Mag. 3: 105 (1789).

${ }^{2}$ Bot. Reg. n.s. 13: 42 (1840).

${ }^{3}$ Pl. Hist. 3: 605-606, fig. 4 (1699).

4Inst. 3: fig. 193 (1700). 
eight different polynomials of previous writers. Ruppius ${ }^{1}$ was the first to coin the name Tradescantia in 1726, citing Tradescantia sive Ephemerum Virginiana, based upon Ephemerum Virginianum, flore coeruleo, minore ascribed to Tournefort. Ruppius also called attention to the variety of color displayed by the flowers, remarking "Floris colore variat. Hinc Ephemerum Virginianum flore candido mox coerulescente Tournefortii."

The genus Tradescantia was established by Linnaeus ${ }^{2}$ in 1537 with a single species, $T$. virginiana. Two specimens of this species are to be found in the Linnaean Herbarium of the Linnaean Society of London, one a plant of true T. virginiana L.; the other of T. subaspera Ker-Gawl. var. montana (Shuttlew.) Anders. \& Woods. as interpreted in this treatment. The specimen of the latter bears a small piece of paper at the lower left corner with the notation "no. 15 An Tradescantiae species?" and in the lower right corner, written upon the sheet itself "species nova." That interpreted to be true $T$. virginiana bears the simple notation at the bottom of the sheet " 1 virginiana," which was the method employed by Linnaeus in indicating the original speciessheet of monotypic genera, according to Jackson ${ }^{3}$. The latter specimen has accordingly been interpreted as the type of the genus.

Since the formal publication of the type species in 1753 , numerous species, varieties, and forms have been added to the genus from time to time, many of obviously distant and incongruous affinities which await a revision of the genus as a whole. The tropical and subtropical species are in especial need of critical study. Without discussing individually the nomenclatural history of the species, varieties, and forms indigenous to the United States and accepted as congeneric with $T$. virginiana in this treatment, attention should be directed at this time to several publications issued since 1753 which have greatly influenced the taxonomic interpretations of the genus.

The first significant studies of Tradescantia in the United States appear to have been made by Rafinesque, who was attracted by the showiness of the plants which he encountered in the vicinity of Lexington, Kentucky. Encouraged by the manifest variability

1Fl. Jen. 48 (1726).

${ }^{2}$ Sp. Pl. 288 (1753).

${ }^{3}$ Proc. Linn. Soc. Suppl. 124: 7 (1912). 
of the genus, Rafinesque ${ }^{1}$ published fragmentary descriptions and notes upon six new species in 1832. In $1836^{2}$ this number was amplified by nine new species and twelve new varieties. Although his interpretation of taxonomic units must be deprecated in this genus as in many others, credit is due Rafinesque for his refusal to emulate his contemporaries in blindly relegating the complicated plexus of tradescantias in the United States, in toto, to $T$. virginiana (or $T$. virginica, as miscopied by Linnaeus ${ }^{3}$ in the 'Systema' and numerous subsequent authors.)

In 1881 the Commelinaceae were reviewed for De Candolle's 'Monographiae' by C. B. Clarke, whose revision of the genus Tradescantia reflects little credit upon its author, when compared with the critical, if eccentric observations of Rafinesque nearly a half century previously. Not only was Clarke satisfied to ignore the complexity of the genus by unwarrantedly reducing to strict synonymy or ambiguous varieties most of the species proposed by his predecessors, but the literature was complicated by the publication in synonymy of unpublished names of other botanists, and the misinterpretation of numerous others. The revision of the genus in the 'Monographiae' is clearly a piece of chorework reflecting rather a none too laborious attempt at compilation than a lively interest and acuity.

The first revision of the species of Tradescantia in the United States was a synopsis, somewhat less than a page in length, introduced as a foot-note in Sereno Watson' ${ }^{5}$ enumeration of plants from southwestern Texas and northern Mexico collected chiefly by Edward Palmer. In this synopsis Watson recognised six species and two varieties. Although this revision was more satisfactory from our standpoint than any previously attempted, the author appeared to have profited remarkably little from the earlier observations of Rafinesque, possibly because of an inherited prejudice; and his neglect of other important literature which was doubtless available to him was unfortunate as well.

Dr. John K. Small has probably influenced the speciation of Tradescantia more than any botanist of the contemporary generation. Although evidenced by a previous contribution to the

${ }^{1}$ Atl. Jour. 1: 148-150 (1832).

${ }^{2}$ Rafinesque, New Fl. 2: 84-87 (1836).

'Syst. ed. 10. 975 (1759).

'DC. Monogr. 3:287-309 (1881).

5Proc. Amer. Acad. n.s. 18: 168 (1883). 
genus $^{1}$, the results of his observations afield were first given significant form in an article entitled "The genus Tradescantia in the southern States" "which appeared in 1897. Four new species were proposed; in addition two species of Rafinesque were revived, and a key provided to the eleven species recognised in the southeastern states. This treatment was also noteworthy because of its ample descriptions and citation of specimens. Small's subsequent treatment of the genus in his well-known "Flora of the southeastern United States" clarify our understanding of Tradescantia.

In 1899 Dr. J. N. Rose ${ }^{4}$ proposed three new species of Tradescantia from the southwestern United States as the result of a long and intimate study of the genus. In presenting his article, Rose announced that a general revision of the genus was in process, upon which he had been engaged for some time. Under his direction a set of illustrations in water colors was prepared, and living plants were sent from many parts of the country for culture in Washington. Effort was made also to secure several species of dubious status, and Rose personally collected living and dried specimens in numerous instances. For some reason which has not been explained, however, the projected monograph did not materialise before the untimely death of the author in 1928.

The most recent contribution to the systematics of Tradescantia is a treatment of the species of Texas by B. F. Bush. ${ }^{5}$ Recognising a total of eighteen species for the relatively limited region chosen, nine of which were new to science, Bush's revision is the most ambitious of recent treatments of the genus, consisting of an analytical key, descriptions of species, and citations of specimens from two of the larger American herbaria. Two additional species from Texas were published by $\mathrm{Bush}^{6}$ a year later. Bush's revision of the Texas tradescantias represents an admirable approach of the genus in its most difficult range, although the author was handicapped by his failure to appreciate the widespread hybridization which occurs in the field.

${ }^{1}$ Small \& Vail, Mem. Torrey Bot. Club, 4: 160 (1893).

${ }^{2}$ Small, Bull. Torrey Bot. Club, 24: 228-236 (1897).

${ }^{3} \mathrm{Fl}$. Southeast. U.S. ed. 1. 238-241 (1903); ed. 2 (1913).

${ }^{4}$ Contrib. U. S. Nat. Herb. 5: 204-206 (1899).

${ }^{5}$ Trans. Acad. Sci. St. Louis, 14: 181-193 (1904).

${ }^{6}$ Rep. Mo. Bot. Gard. 16: 100-101 (1905). 


\section{GROSS MORPHOLOGY}

Habit. The species of Tradescantia are all subsucculent, perennial herbs. As represented by the indigenous species of the United States, the stems are erect or ascending in all save one species of extreme southern Texas and the lower Rio Grande valley, $T$. micrantha Torr., which is largely distinguished by a trailing or creeping stem which roots more or less freely at the lower nodes. In two other species of Texas, $T$. humilis and $T$. subacaulis, the plants produce numerous stems from the crown which are typically more or less diffuse in posture. A similar habit is found also in T. paludosa of the Mississippi delta region.

In contrast to the tropical representation of the genus, vegetative propagation is not highly developed in most of the species of the United States. Tradescantia virginiana, $T$. subaspera, and their close relatives seldom produce clones more than a foot or two in diameter. Because of its bearing on cyto-genetic theories this question has been extensively discussed in a paper by the senior author. ${ }^{1}$ In $T$. micrantha, and to a less extent in $T$. paludosa, there is more or less active vegetative propagation by roots from the nodes of decumbent stems. Vegetative propagation by relatively elongate rhizomes is evidently limited to $T$. bracteata.

In all species the region of the nodes is more or less swollen or geniculate. In $T$. subaspera this tendency is further accentuated by a conspicuous flexuose development of the stem in var. typica, whilst in var. montana the stems are straight or nearly so. Branching occurs to a greater or lesser extent throughout the species, intergrading from leafy branches, usually arising from the basal or lower nodes, to leafless, lateral inflorescences above. The only known species with truly simple stems is $T$. Wrightii, an endemic of the Guadaloupe Mountains of extreme western Texas. The subsucculent stems of all species contain a mucilaginous juice which is very irritating to the mucuous membranes due to the presence of quantities of raphides apparently of calcium oxylate or some similar compound.

Roots. The roots of the species of Tradescantia as a whole are fibrous and more or less fleshy. In the species of the United States the fleshy quality is least pronounced in $T$. micrantha, a small, trailing species of moist habitats, with fascicles of rather

${ }^{1}$ Anderson, E. \& D. G. DieHL in Jour. Arnold Arb. 13:213-231 (1932). 
short, slender roots at the lower nodes. The roots of $T$. rosea and its varieties are also somewhat less fleshy than in the group of $T$. virginiana and the more typical element of the genus. In $T$. occidentalis an interesting departure in the morphology of the root is found in the predominant occurrence of both fleshy and somewhat slender primary roots upon the same plant. In this manner one is frequently able to distinguish the roots of $T$. occidentalis from those of $T$. canaliculata ( $=T$. reflexa Raf.) which are more uniform in constitution.

The slight indication of heteromorphy in the roots of $T$. occidentalis is more pronounced in T. humilis and $T$. subacaulis, in which conspicuous, fleshy roots which are more or less enlarged distally occur with more slender primary roots. Although such subtuberoid roots are frequently longer than the more slender ones, their fleshy structure makes them crisp and easily broken. Hence ordinary collection of herbarium specimens is apt to accentuate their subtuberoid appearance, making them appear somewhat shorter in proportion to their girth than is actually the case. In $T$. pinetorum heteromorphy of the roots attains the maximum within the species of the United States, and here few to several fleshy, fusiform or fusiform-napiform tubers $1-3 \mathrm{~cm}$. long and $0.5-1.0 \mathrm{~cm}$. in thickness are borne among interspersed, short and fibrous roots rather similar in appearance to those of $T$. micrantha. The tubers of $T$. pinetorum are evidently the most pronounced of the genus, but in Mexico T. venustula, T. linearis, and $T$. rhodanthera are found to possess roots somewhat intermediate between those of $T$. pinetorum and $T$. subacaulis, except that they appear to be uniformly subtuberoid, without the more slender, interspersed roots as in the related species of the United States.

The persistence of the supposedly evanescent root hairs is a phenomenon which appears to be much more frequent than is generally supposed. In recent years there have been scattering reports of permanent pilosity upon the roots of certain plants, and the phenomenon has been carefully studied by Miss E. A. Whitaker ${ }^{1}$ with respect to certain species of Compositae, Leguminosae, and the genus Lysimachia of Primulaceae. Casual observations indicate that the persistence of root hairs is common in many monocotyledons, possibly a tendency attaining final expression in the velamen of the Orchidaceae.

'Bot. Gaz. 76: 30-59 (1923). 
It is strange that the persistence of the root hairs of Tradescantia has not been studied in connection with this problem, for in certain species the indument is extremely conspicuous, as in $T$. Reverchoni Bush, consisting of densely matted, ferruginous hairs $1-4 \mathrm{~mm}$. in length. The persistent root hairs appear to be excellent specific indicators in several instances. $T$. hirsutiflora, the closest relative of $T$. Reverchoni, is instantly distinguished from that species by the roots alone, which are glabrate or with merely a sparse, grayish pubescence. Although ecological conditions may well be held responsible in some degree for the persistence of the radical indument, it scarcely appears likely that this factor is alone accountable for the difference, for both species inhabit similar environments, namely, the deep sandy soil of eastern Texas and adjacent Louisiana.

A parallel situation is found in peninsular Florida for the varieties of $T$. rosea Vent.; var. graminea having nearly or quite glabrate roots, and var. ornata roots which are densely whitelanate while in var. typica, intermediate in several respects between the preceding varieties, the roots are rather sparsely and irregularly grayish-puberulent. Although the persistence of root hairs to a lesser degree occurs rather irregularly in other species of the genus, as in T. canaliculata, the most pronounced occurrence is found in $T$. Reverchoni and $T$. rosea var. ornata. Since both entities frequent deep, sandy soil, it would doubtless be unwise to discount absolutely ecological factors as a causative agent in the production and retention of the indument. Since both prefer somewhat more water than their immediate relatives it is possible that moisture relations should also be examined in this connection.

Leaves. The taxonomic criteria found in the leaves are among the most important in the delimitation of the species of Tradescantia. Of such leaf characters, the general outline and proportions are outstanding. The leaves of all known Commelinaceae consist of a prominent blade which is produced basally into a perfoliate sheath. In the tradescantias of the United States the relative proportions of the leaf blade and the sheath, hence the gross outline of the entire leaf, are of prime importance. The outline of the leaf as thus analysed, supported by additional characters of the leaf and other organs, assists materially in placing the various specific entities in a few manifestly natural groups. 
In analyzing the outline of the leaf for the purpose of speciation, the relative width of the blade and sheath have been found to be of the utmost value. In computing the width of the sheath it is perhaps evident that the surface width of this part of the organ as observed when removed from the node and split open

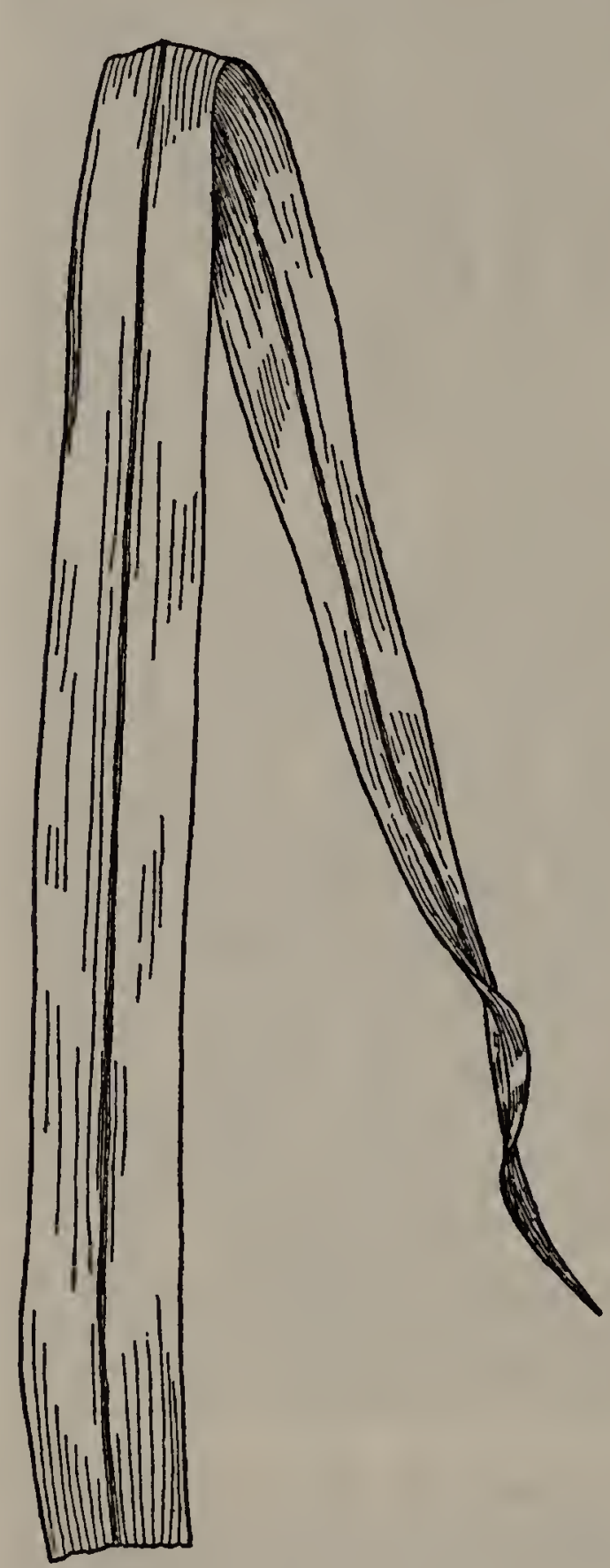

a

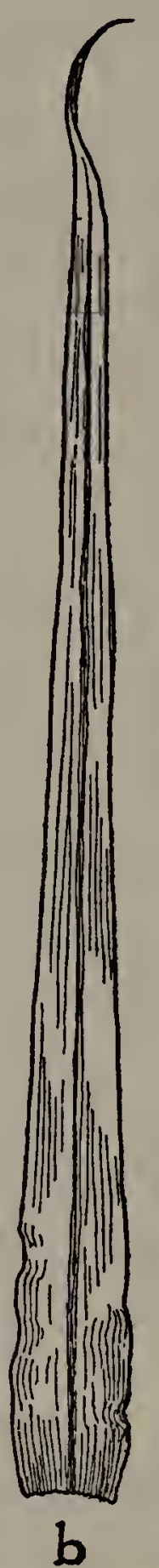

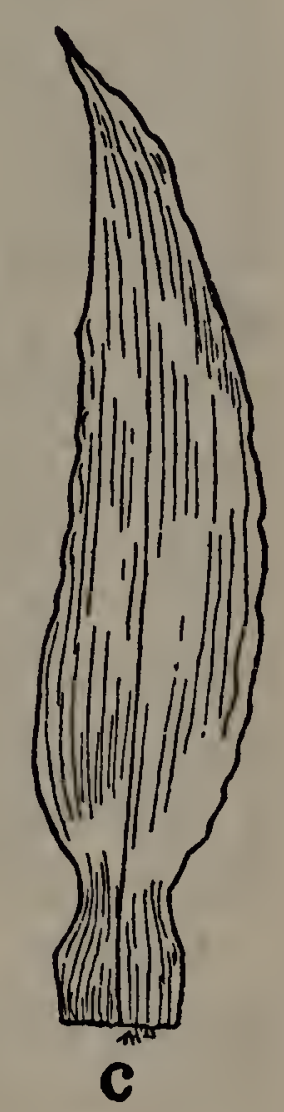

Figure 1. Relative widths of sheath and blade in leaves of representative species of Tradescantia. (a) sheath and blade of equal width (b) sheath wider than blade (c) blade wider than sheath.

is meant rather than the diameter of the sheath intact as found in place upon the stem. Diagrams of such detached leaves of representative species are given in text fig. 1 . The leaves of the species as thus represented fall into three main groups, viz., those in which the blade is manifestly broader than the sheath, 
those in which the blade and sheath are of about equal width, and those in which the sheath is broader than the blade.

Omitting to discuss the gross position of the leaf which is occasionally associated in some characteristic manner with more important criteria of taxonomic units within the genus, we turn to the color, or rather the "cast," of the foliage. In this instance close correlation is found with the outline, since the foliage of the group of species having the leaf blade broader than the sheath, centering about T. subaspera, is of a dull or "mat" green above, and markedly paler beneath. The leaves the blades of which are narrower than the sheath, as in $T$. canaliculata and its immediate relatives, are almost uniformly glaucous above and beneath, with a pallid cast and usually with somewhat of a bloom. The intermediate group of species, represented by $T$. virginiana and its close neighbors, have leaves the surfaces of which are scarcely as uniform in cast as in the immediately preceding group, but without the sharp contrast of the first.

The cast of the foliage has been found to be due largely to the distribution and number of stomata present upon either surface. The air spaces of the mesophyll are rather large and betray the presence of the stomate-bearing areas to the naked eye by small white dots. In the group of species typified by $T$. subaspera the stomata are virtually restricted to the lower surface of the leaf. Therefore the leaf is markedly paler in color below than above. The guard cells of the stomata can be made out sufficiently with the magnification of a hand lens. With such magnification one can observe as well that the sharp difference in the cast of the leaf surfaces of this species may be due in part to the orientation of the epidermal cells themselves, which occur with the longer axis roughly parallel to the axis of the leaf blade below, and with the longer axis of the cell nearly horizontal to the axis above. The cell shape of both the upper and lower epidermis is almost perfectly rectangular. The occasional stomata found upon the upper surface also have the orientation of the other epidermal cells.

In the group of species typified by $T$. canaliculata the stomata are distributed in about equal numbers upon the upper and the lower surfaces, although somewhat more densely upon the latter. This fact, in addition to the slight waxy bloom usually present, renders the foliage nearly concolorous and characteristically pallid. The mode of distribution of the stomata may be of passing 
interest in this connection. The stomata upon the lower surface of the leaves freely fill the interstices of the parallel veins. Upon the upper surface, however, they occur in the main in rows parallel to the veins. In other words, the upper surface is roughly striped with alternating veins, rows of stomata, areas of basic epidermis, and additional rows of stomata.

The intermediate color of the leaves of $T$. virginiana and its immediate relatives is accounted for by the fact that although the greater number of stomata occur beneath, the upper surface is also occupied by stomata in considerable numbers. Here the mode of distribution of stomata upon either surface is essentially as observed for $T$. canaliculata but not to such a pronounced degree.

Lest it be charged that such characters as the distribution of stomata upon leaves must be a minor and rather inconsequential consideration from the aspect of taxonomy, it should be pointed out that in specimens of suspected hybridity, as, say $T$. canaliculata and $T$. subaspera, the distribution of the stomata, very sharply defined in either parent, has proved to be markedly intermediate in the offspring. Experimentally produced hybrids of $T$. canaliculata and $T$. subaspera, as well as obviously intermediate individuals found in mixed colonies, have shown themselves to be exactly as one would expect them to be with reference to the stomata of the leaves. It can scarcely be gainsaid that evidence tested in the experimental garden and in the field should be of service in the herbarium as well. Incidental reference might be appropriate at this juncture to the use of the foliar epidermis by Piper ${ }^{1}$ in the speciation of certain barberries. Photographs of the leaf surfaces of representative species of Tradescantia are provided in Plate 2.

Basal leaves as well as the clusters of leaves frequently produced in early autumn upon old stems and viviparous shoots of the inflorescence frequently differ remarkably from the normal cauline foliage. In T. Ernestiana the basal leaves are narrowly oblong to linear, in marked contrast to the broadly ellipticlanceolate leaves of the stem. The somewhat inverted appearance of the foliage of this species is further accentuated by the leafy bracts of the inflorescence which are usually broader than the stem leaves. In $T$. paludosa the basal leaves are also somewhat

${ }^{1}$ Contrib. U. S. Nat. Herb. 20:437-451, pl. 24-26 (1922). 
narrower than the normal stem leaves and the blade is without the characteristic, slight constriction. It has also been found that the relative number of stomata upon the basal and autumnal leaves is somewhat higher than upon the normal foliage. With respect to both outline and leaf surface, therefore, the early spring and autumn foliage of $T$. paludosa suggests that of the closely related $\dot{T}$. canaliculata.

Inflorescence. Although certain tropical species at present included within the genus Tradescantia produce relatively elongate, scorpioid or helicoid cymes as well as other modifications of the determinate construction, all species indigenous to the United States produce their flowers in tight umbels which are found to be dichotomously helicoid upon dissection. Since the umbels are helicoid structurally, they are bilaterally symmetrical.

Subtending either equal half of the flattened, umbellate cymes is a spathe-like bract. In the majority of the genus as represented in the United States the bracts are foliaceous and nearly or quite as large as the cauline leaves which they closely simulate in all respects. Occasionally the uppermost node of the stem is suppressed causing the umbel to appear subtended by three in place of the customary two bracts. Chance occurrences of this nature appear to explain the origin of the pair of "bracts" typically present, which are lacking in the majority of tropical species with more elongate inflorescences.

In three varieties of $T$. rosea, indigenous to the southern Atlantic Coastal Plain of the United States which have been segregated as the genus Cuthbertia by Dr. J. K. Small, the bracts are extremely reduced and are scarcely distinguishable from the inconspicuous, hyaline bracteoles which subtend the individual flowers. In $T$. rosea vars. typica and ornata the bracts are scarcely manifest and have lost the foliaceous texture characteristic of the typical element of the genus. In var. graminea, however, the bracts are clearly manifest and are definitely foliaceous in texture, thus providing a tangible connecting-link between $\mathrm{Cuth}$ bertia and the typical element of Tradescantia. In nearly all the earlier treatments of the genus the condition of the inflorescence of $T$. rosea has been described as "long-peduncled"" and that of more typical species as "sessile or nearly so.". A thorough examination of either type of inflorescence will reveal that they are

${ }^{1}$ cf. Gray, Man. ed. 7. 264 (1908); Britton, Man. ed. 2.241 (1905). 
quite homologous, and cannot be separated as quoted with any sense of propriety. The sole difference lies in the amount of reduction of the homologous "bracts."

Calyx and Pedicels. Quite aside from the character of the indument, which will be considered as a whole for all the organs in subsequent paragraphs, the calyx and pedicels of the species of Tradescantia indigenous to the United States offer several taxonomic criteria of importance. Foremost of these are the texture and coloring of the former and the relative length and coloring of the latter.

The texture and coloring of the sepals furnish one of the most easily perceived clues to identities and relationship in the genus, although they have not been used as such in the previous literature. The sepals are predominantly more or less foliaceous among the species. Nevertheless, the relative texture and cast are frequently distinctive in several closely related species. Two of the most poorly defined species considered in this paper are $T$. virginiana and $T$. hirsutiflora, the former native to the northeastern states from southern Connecticut and northern Georgia to Iowa and Missouri, and the latter to the southeast-central states from northern Florida to southern Arkansas and central Texas. Without regard to the indument which is distinctive as a rule, the texture and color of the sepals is sufficient to distinguish the two species. The sepals of $T$. virginiana are relatively delicate in texture and are a bright, slightly yellowish green in color. Moreover, they always have a somewhat inflated or turgid appearance which is quite characteristic. On the other hand, the sepals of $T$. hirsutiflora are typically more heavy in texture, and their color is a duller, darker green, not rarely edged or somewhat suffused with pink or purple, an occurrence never observed in $T$. virginiana. The calyx of the former species, furthermore, is without the inflated appearance found in that of the latter.

Tradescantia hirsuticaulis, $T$. Tharpii, and T. longipes are particularly noteworthy because of their more or less petalaceous and florid calyces. In the last named species, particularly, the sepals as well as the pedicels are bright rose-purple in color, rivaling the intensity of the petals. Because of the showy coloring of the sepals and pedicels, as well as for the diminutive size of the plants and the large number of flowers produced at one time, $T$. longipes is one of the most promising species of the genus from a horticultural standpoint. 
The petalaceous texture and coloring of $T$. longipes is also found in $T$. Tharpii and T. hirsuticaulis, but to a somewhat less extent. In $T$. Tharpii the sepals and pedicels grade from bright rose-purple to pale yellowish green in single colonies. In $T$. hirsuticaulis the petalaceous development of the calyx appears to be somewhat more pronounced in its western distribution than eastward. In the eastern portion of its range it is common for the petalaceous coloring to be more pronounced in the sepals of flowers which have failed of pollination. Fruiting calyces frequently undergo a slight foliaceous development during the early stages of seed production.

In several species, notably $T$. canaliculata, $T$. rosea, $T$. occidentalis, and their immediate relatives, the sepals are nearly hyaline, or only slightly foliaceous. The sepals of $T$. canaliculata and $T$. occidentalis and their relatives are not infrequently found slightly suffused with rose or purple. This tendency toward petalaceous development is somewhat more decided in the latter species.

The sepals are rather uniformly ovate-elliptic in shape; the apex grades from acute to acuminate. Although the relative width of the sepals, naturally, tends to definite norms within the species, sepal shape has not been found sufficiently distinctive to warrant its use as a taxonomic criterion. The length of the sepals, likewise, has been found to be of little advantage in the delimitation of species although varying characteristically within relatively definite limits. In general, sepal length may be found to vary from $0.4-1.2 \mathrm{~cm}$. in the species under discussion. $\mathrm{Ab}-$ normally foliaceous sepals, at times attaining $2-4 \mathrm{~cm}$. in length have occasionally been found upon plants infected with a fungus which Dr. G. D. Darker, who has cultured it, has identified as a species of Acremonium.

The petalaceous coloring of the sepals of several species finds a parallel development in the pedicels. In $T$. hirsuticaulis, $T$. Tharpii, and $T$. longipes, previously discussed in connection with their showy sepals, the pedicels are similarly suffused with rose or rose-purple. Slight tinting of the pedicels may also occur with a similar coloration of the calyx in such species as $T$. occidentalis and $T$. canaliculata. In $T$. subaspera an anomaly is found, where the sepals are subhyaline or only slightly foliaceous and the pedicels predominantly a decided blue-purple. A similar tendency toward the coloration of the pedicels without a correspond- 
ing tendency in the sepals has also been found in individuals of the closely related $T$. edwardsiana.

Although the length of the pedicels is not noteworthy in the majority of species of Tradescantia in the United States, varying in general from 1.0-3.5 cm, in $T$. Tharpii and $T$. longipes the pedicels attain a length of $4-6 \mathrm{~cm}$. After maturity the pedicels of all species are reflexed and more or less accrescent if fertilisation has ensued.

Corolla. The corolla of the genus Tradescantia is apopetalous, and is ephemeral as in other members of the Commelinaceae. The manner in which the petals hydrolyse has been the subject of several physiological studies, from which it appears that this characteristic phenomenon of Commelinaceae is actuated by the agency of certain enzymes. The dissolving of the corolla into an aqueous mass has earned for the genus the popular name "Widow's tears," which has also been applied to Commelina. The hydrolysis of the petals is closely correlated with temperature, and upon fairly cool days the flowers may retain their form until late afternoon. In the heat of summer, however, hydrolysis frequently begins before the buds have completely expanded.

The delicate texture of the petals of Tradescantia and their tendency to hydrolyse render them extremely difficult to preserve adequately as herbarium specimens. Fortunately, however, few taxonomic criteria are possessed in the corolla, and none are necessary in the identification of species as they are recognised in this paper. The color of the petals, in particular, appears to have been greatly over-emphasised by some students of the genus, since a wide range of shades, from blue to magenta, and less frequently white, may occur in a single colony of certain species. In other species blue, magenta, or rose are found apparently without intergradations. In two species, $T$. rosea, and T. micrantha, the color of the petals is apparently invariably pink or rose. The tendency to color variation from blue to magenta, purple, violet, pink, white, etc. has been found cytologically to be closely connected with the chromosome complement in several species, ${ }^{1}$ the more variable being tetraploid in all instances investigated, and those with well-marked shades of blue and rose only, being diploids. This correlation of color variation and chromosome number has also been found to obtain in the

${ }^{1}$ cf. Anderson, E. and D. G. DienL, Jour. Arnold Arb. 13: 213-231 (1932). 
case of tetraploid and diploid colonies of single species, notably $T$. canaliculata ( $T$. reflexa).

The gross size of the petals of various species has been found to be quite characteristic in some instances, particularly in the small-flowered species. The broadly ovate outline of the petals of the species represented in the United States finds an exception only in the petals of $T$. gigantea Rose, which are broadly obovate. Indistinct crenulation or fringing of the petal margins occurs rather irregularly in certain species, notably in $T$. rosea var. ornata.

Ovary. Aside from their characteristic induments which are of the very greatest aid in speciation, the ovaries of Tradescantia are of little interest in the delimitation of species. Although the shapes and sizes vary slightly among the species, as is to be expected, these characters have not been found to be particularly significant in any instance. The shape of the ovary varies from broadly ovoid or obovoid to ovoid-pandurate. One or two orthotropous ovules are contained within each of the three loculi. A consideration of the indument of the ovary is reserved for subsequent paragraphs.

Stamens. The six, equal stamens of the genus Tradescantia are uniform and fertile. The anthers are borne upon a slender filament and consist of two unilocular sporangia united by an extensive, sterile connective. In the species indigenous to the United States the connective is always broadly and roughly trapezoid to subtriangular. The loculi are always broadly reniform. The anthers have been searched in vain for tangible systematic criteria, notable in certain tropical species. A peculiar development was found in the coloration of individuals of the Texan T. humilis, however, in which the loculi are warm-brown and the connective butter-yellow.

Several species with glabrous filaments have been relegated to Tradescantia in the past. In the United States the only such species has been $T$. floridana $\mathrm{S}$. Wats. ( $T$. cordifolia $\mathrm{Sw}$.) which is transferred to the genus Callisia in a subsequent section of this paper. The remaining species of the United States, therefore, have filaments upon which the well known moniliform, multicellular hairs are conspicuous. The stamen hairs are ephemeral like the petals, and are almost invariably of a similar color. In whiteflowered plants of such species as T. canaliculata, however, the stamen hairs are ordinarily blue, although true albino forms with 
white stamen hairs are occasionally encountered. Although most species of Tradescantia have abundant hairs distributed rather uniformly along the filament, T. humilis and T. subacaulis have perceptibly fewer hairs which are more nearly localised toward the lower half of the filament. This situation is also found in T. micrantha. All three species are confined to southern Texas.

Indument. The remarkable persistent pilosity of the roots of certain species of Tradescantia has been discussed in previous paragraphs. A taxonomic criterion of major importance which has long been appreciated by systematists treating with the genus is the indument of the aërial organs of the plants. Although the stem, leaves, and bracts frequently bear a more or less conspicuous hairy covering among the species of the United States to which we have devoted our attention, the indument of the calyx and pedicels has merited particular consideration. The hairs present not only upon the calyx and pedicels but upon the other aërial organs as well are found to be either glandular or eglandular. When glandular the individual hairs, which are always composed of several cells, are tipped by a single conspicuously swollen, oblongoid secretory cell. When eglandular, the hairs, which are unicellular as well as pluricellular, gradually taper to an acuminate tip. The epidermal hairs are frequently somewhat bullate, although it has not appeared possible to correlate this character with specificity. The glandular hairs are frequently found to imitate the eglandular by the loss of the terminal, secretory cell. This loss is particularly noticeable toward the end of the fruiting season. Mutilated glandular hairs are ordinarily easy to detect in any event by means of their truncate tips.

The nature and distribution of the pubesence has been found to be closely connected with specificity in American species of Tradescantia. The sepals are apparently the most trustworthy organs in this regard. A few examples will illustrate the manner in which the indument of the calyx has been employed systematically in this treatment. In T. canaliculata the sepals appear to be in about equal numbers either absolutely glabrous or laxly eglandular-barbate at the extreme tips. The glabrous or barbate sepals are uniform for the entire plant, but examination of individual colonies and an analysis of the geographic distribution of both types, as well as a search for accompanying morphological characters, have failed to reveal evidence to deny con- 
specificity. Whether the glabrous and barbate sepals represent subspecific categories has likewise appeared impossible to establish definitely. The weak hairs found at the barbate sepal tips of $T$. canaliculata are invariably eglandular. The pedicels are always glabrous.

The conspicuously foliaceous sepals of $T$. virginiana are uniformly covered with villous, eglandular hairs. The indument of the calyx of typical T. occidentalis, on the other hand, is uniformly composed of short, gland-tipped hairs. The pedicels of both species are clothed predominantly as in the calyx, varying to glabrate in $T$. occidentalis. In the latter species, moreover, glabrate calyces are found frequently, in which case the base of the sepals is the region last to retain the pubescence. $T$. occidentalis var. scopulorum is absolutely glabrous throughout.

Natural hybrids between the species discussed in the preceding paragraphs are clearly distinguished by means of the indument of the calyx. Hybrids of $T$. canaliculata and $T$. virginiana are evidenced by the uniformly pubescent sepals with a conspicuous, apical tuft, among other things, if the supposed parent of $T$. canaliculata has been of the type with barbate sepals. Experimental hybrids of this cross have also been made with identical results. Natural hybrids of $T$. canaliculata and $T$. occidentalis have been encountered in the field in conjunction with colonies of either of the supposed parents and are discussed fully in the systematic account of $T$. occidentalis. In this cross the sepals of the hybrids have been found to be more or less uniformly glandular-pubescent with the addition of a tuft of weak, eglandular hairs as in typical barbate individuals of $T$. canaliculata.

The participation of barbate plants of $T$. canaliculata in hybridization is obviously more conspicuous than that of glabrous individuals, which is nevertheless evidenced in other characters, such as relative width of leaf blade and sheath, color of foliage, texture of sepals, etc. Both T. canaliculata and T. occidentalis occur commonly in the state of Texas, the former being restricted roughly to the eastern half of the state, and the latter approximately to the western two-thirds. In the territory common to both species hybridization is evidently extremely common since it is difficult, among such a large number of herbarium specimens as has been critically examined in the course of this study, to detect individuals of $T$. occidentalis, empirically separated from other species by the presence of an apparently uni- 
form glandular indument, without some trace of a tuft of weak, eglandular hairs in the manner of $T$. canaliculata (see text fig. 3 ). Time has not permitted the synthesis of the cross of $T$. virginiana and $T$. occidentalis, and as the two species occupy separate ranges, natural hybrids have not been found as yet.

A third type of indument found upon the calyx of such species as $T$. bracteata, $T$. hirsuticaulis, T. humilis, and T. Reverchoni occurs in which glandular and eglandular hairs are uniformly and freely dispersed. In this instance the glandular hairs are somewhat longer and weaker than in T. occidentalis. The analysis of the "mixed" indument is ordinarily rather difficult, and the use of a fair magnification is usually essential. ${ }^{1}$ At times the glandular and eglandular hairs are about equally distributed, or the former may be preponderant. At times the glandular hairs are greatly in the minority. It is thought possible that a similar "mixed" indument might be synthesized in the hybrid of $T$. virginiana and T. occidentalis should such a cross prove feasible.

Three species of Tradescantia indigenous to the United States bear calyces the indument of which might be said to prove the constancy of the same character in other species by means of its variability. In $T$. subaspera plants have been found with sepals uniformly non-glandular, uniformly glandular, and mixed glandular-eglandular with regard to their indument. Upon geological as well as morphological grounds it is thought possible that this species may represent a relatively ancient element in the genus as represented in the extant flora. The reasons for such an assumption are briefly offered for acceptance or rejection in the systematic treatment of the species in a subsequent section of this paper. Temporarily entertaining such an assumption, it might follow that the more specialised induments of less ancient species have been derived perhaps from such a plastic and variable pubescence as that of $T$. subaspera. Be that as it may, the pubescence of the closely related T.edwardsiana of the highlands of the southern Ozarks and the Edwards Plateau, only rivaled in age the southern Appalachian range of T. subaspera, is found to be definitely glandular, although occasional, dispersed, eglandular hairs are infrequently to be observed. The perplexing

${ }^{1}$ For the critical study of indument in Tradescantia species the writers have employed a binocular dissecting microscope with $12.5 \mathrm{X}$ oculars, and $3.4 \mathrm{X}$ or $10 \mathrm{X}$ objectives. Transmitted illumination has been found to be most effective. Herbarium specimens are softened in boiling water and mounted with water between two glass slides. 
and rather heterogeneous $T$. hirsutiflora offers an analogy to $T$. subaspera in the indument of the sepals, which may be eglandular or mixed-glandular. From a wide selection of herbarium specimens it appears probable that $T$. hirsutiflora interbreeds freely with other species found in its range.

From a prolonged examination of ovaries, both in the herbarium and in the field, a striking correlation has been found between the pubescence of the calyx and pedicels and the pubescence of the ovary. Of the species discussed in the immediately preceding paragraphs it has been found that the ovary of glabrous specimens of $T$. canaliculata is also glabrous predominantly, although occasional specimens are also to be found with a tuft of weak, eglandular hairs at the base of the style; flowers with barbate sepals produce ovaries which are eglandular-barbate at the tip. The ovary of $T$. virginiana is covered with uniformly eglandular hairs; that of $T$. occidentalis is covered with short, glandular trichomes. Hybrids of $T$. canaliculata and $T$. virginiana as well as $T$. canaliculata and $T$. occidentalis possess an ovarian indument coinciding in quality with that of the calyx. The pubescence of the ovary of such species as $T$. bracteata, $T$. humilis, T. hirsuticaulis, and T. Reverchoni is very closely correlated with that of the sepals, which is also found to be the situation in the species with more plastic indument as $T$. subaspera and T. hirsutiflora.

In a general way the indument of the stem and leaves, when present, bears some relation in quality to that of the sepals and ovary, but has appeared too plastic in this regard to permit of use as a taxonomic criterion, and is too inconstant to be discussed at this time. Perhaps the most remarkable vegetative indument of the genus is found in $T$. subacaulis and $T$. Reverchoni which consists of long, weak, more or less matted hairs, described as arachnoid-villous, borne upon the stems and leaves. Dispersed among the arachnoid, eglandular hairs is a variable number of shorter, gland-tipped hairs. Photomicrographs of the indument of characteristic species of Tradescantia are found in plate 6.

Seeds. Although self-sterility is common, if not the rule among the group of tradescantias considered in this paper, fruit is produced abundantly in all but one species, T. micrantha, which apparently relies wholly or in large degree upon vegetative propagation. The capsules are dry and papery, dehiscing loculi- 
cidally into three valves. The capsules differ more or less in shape, from oblongoid- to obovoid-trigonal, but this character has not seemed particularly promising in the delimitation of species. Quite naturally the size and general shape has been found to differ in species otherwise quite sharply distinguished. In only one instance, however, have the capsules aided in differentiating closely related species, notably in $T$. subaspera and $T$. edwardsiana, with capsules $0.4-0.6 \mathrm{~cm}$. and $0.8-1.0 \mathrm{~cm}$. long respectively.

The seeds are roughly compressed-oblongoid to compressedsubspherical or subtrigonal, and vary from $0.15-0.4 \mathrm{~cm}$. in length. They are somewhat inconstant in number, three to six being produced within each capsule. The number of ovules fertilized within a single cavity of the ovary has a profound effect upon the shape of the seed, as well as upon the size. Seeds borne singly have uniformly tapering ends and more nearly oblongoid or subspherical shape. When two seeds are borne within the same locule, however, they are slightly smaller in size, and the abutting walls are conspicuously flattened or truncate. The dark brown or yellowish testa is more or less rugose and radiately ridged, but the surface is extremely variable for the species, and although possibly of use taxonomically within the genus as a whole, it has not been found so in the delimitation of the species occurring in the United States. Upon the dorsal surface of the seed the micropyle becomes transformed at maturity into a conspicuous, sunken projection surrounded by a roughly circular pit. The character of the pit varies to some degree within the species, but is so inconstant among seeds within the same capsule that is has not been satisfactory as a taxonomic character.

The general size and shape of the seeds have been of value, nevertheless, when taken into combination with the character of the funicular scar. When analyzed by means of the nature of the seed in this way, groups of species are given a most natural accentuation. It has been found that $T$. subaspera, $T$. virginiana, $T$. canaliculata, $T$. occidentalis, and their immediate relatives have seeds which are roughly compressed-oblongoid in shape, $0.2-0.4 \mathrm{~cm}$. long, with a linear funicular scar extending nearly the entire length of the seed. In $T$. pinetorum and $T$. Wrightii the seeds are broadly compressed-oblongoid to subtrigonal, and the linear funicular scar is only about half as long 
as the seed. On the other hand, in $T$. rosea, the seeds are very broadly oblongoid to supspherical, and the funicular scar is punctiform. This character is seemingly one which can elucidate the taxonomy and phylogeny of the entire genus, as T. geniculata Jacq., T. amplexicaulis Klotsch, T. angustifolia Robinson, and T. Disgrega Kunth have seeds more closely approaching the nature of those of $T$. Wrightii and T. pinetorum, species which have obvious affinities in the genus as represented upon the Mexican Plateau rather than with the remaining representation in the United States.

Although the seeds of $T$. micrantha are not at present known, the affinities of this species are quite strongly with $T$. brachyphylla of northeastern Mexico, the seeds of which are compressedsubspherical with a prominent pit and a funicular scar of approximately equal length. T. cordifolia Sw. (T. Floridana S. Wats.) has been transferred to the genus Callisia partly on the character of the seeds, which are compressed-subspherical, $0.1 \mathrm{~cm}$. or somewhat less in diameter, with an inconspicuous pit and a punctiform funicular scar subtended by an inconspicuous, decurrent ridge. Seeds of representative species of the United States are illustrated by photomicrographs in plate 3 .

\section{SPECIATION}

This study was undertaken to provide a taxonomic background for cytogenetic investigations. The exchange, however, has not all been in one direction. The experimental work has provided us with a large body of evidence bearing in one way or another upon questions of classification. That evidence has been of peculiar importance in shaping our concepts of species and varieties in the genus Tradescantia. It is the object of this section to summarize the outstanding points in that evidence, in so far as they have influenced our conceptions of speciation in Tradescantia.

1. Tradescantia virginiana and its close relatives are selfsterile, that is, a plant belonging to these species will not set seed with its own pollen, though the pollen be capable of fertilizing other plants. When two such species are growing in close proximity and flower at the same time, inter-crossing is encouraged.

2. Many species are inter-fertile. All the American species allied to Tradescantia virginiana (nos. 1 to 18 incl. of the present 
treatment) can be intercrossed readily. The resulting hybrids are partially fertile, though less so than the original species. It is a notable fact that the senior author has never seen a Tradescantia virginiana in a European garden which could unhesitatingly be referred to that species. Most of the plants in cultivation under that name show unmistakable evidence of mixture with $T$. canaliculata and $T$. subaspera.

3. Cytologically the species which have been examined can be divided into three distinct groups. The first 18 species of this treatment, comprising Tradescantia virginiana and its close relatives, are characterized by 6 or 12 large chromosomes with median attachment constrictions. Tradescantia micrantha and Tradescantia rosea have very different chromosome garnitures, so different as to indicate a very ancient separation between these three divisions of the genus. Tradescantia pinetorum and Tradescantia Wrightii have not yet been procured in living condition for cytological investigation.

4. Many of the species are polyploids or include such strains. Unlike nearly all other polyploids known in nature they are auto-polyploids. Certain of the effects of auto-polyploidy upon speciation have been discussed in a previous paper. ${ }^{1}$ In so far as monographic work is concerned the most important consequence is the effect upon variability. A cytogeneticist would predict that any auto-polyploid species such as $T$. canaliculata or $T$. virginiana would be exceedingly variable. To him the morphological diversity of these species would be no cause for surprise. He might instead be astonished that with such a complicated arrangement of the germplasm they vary no more than they do. One outstanding cytologist familiar only with the cytological phenomena of $T$. virginiana and its relatives was led to the deduction that these plants were not customarily reproduced from seed. It is therefore felt that there is good biological justification for allowing here a somewhat wider latitude of intraspecific variation than is customary in many other genera.

5. Several of these species are, or shortly will be, hemerophytes, that is plants which are spread by man either intentionally as cultivated plants or unintentionally as weeds. By reason of the enhanced power of travel such plants might logically be expected to have a somewhat different division into species and varieties

1ANDerson, E. and D. G. Dienl, Contributions to the Tradescantia problem. Jour. Arnold Arb. 13: 213-231, tables 1-5, figs, 1-3, pl. 1 (1932). 
than do non-hemerophytes. Geographical variation would be much less intensive, closely related species would have greater opportunities to merge, and advantageously equipped variants would spread much more quickly from the centers in which they originated. As an actual fact, for practical taxonomic purposes, weeds and cultivated plants are often considered as belonging to a somewhat different category than do the strictly indigenous species of a flora.

Several of the species recognized in this treatment are hemerophytes, most of them have that ability to succeed under a variety of environmental conditions which characterizes such plants. Many of them have showy flowers and are easily cultivated. At one time or another, the majority of these species have been grown as garden plants, at least locally. Tradescantia canaliculata, at the present time, is actively extending its boundaries both in the middle west and along the Atlantic seaboard (see below). Tradescantia virginiana has been extensively naturalized in many places. Much of the so-called T. virginiana in cultivation is the result of previous hybridization (probably in cultivation) with $T$. subaspera and $T$. canaliculata. These halfbreeds are already naturalized at more than one point. $T$. subaspera typica was introduced around Philadelphia at an early date by the Bartrams and has become established there. Judging by the comments on herbarium labels, some of the botanists who have collected it recently in that locality assume it to be indigenous there.

We might compare a genus composed largely of hemerophytes to an oil painting originally rich in detail, which had been rubbed while the paint was wet. The American tradescantias, continuing the same analogy, present a picture fairly sharp as a whole, but blurred here and there, and subject to increasing blurring so long as their association with man continues.

\section{HYBRIDIZATION}

In a genus characterized by inter-fertility between closely related species, by self-sterility, and by a strictly perennial habit, one may expect to find a good deal of hybridization taking place. Such hybridization produces relationships between species which are difficult of interpretation. In such a situation field work and cytological analysis are almost indispensible adjuncts to orthodox taxonomic procedure. The authors' conception of 
hybridization in Tradescantia results from the following avenues of approach:

1. An ecological and morphological study, in the field, of colonies in which inter-specific hybridization had been taking place.

2. A cytological study of suspected hybrids collected in the field.

3. A morphological study of herbarium specimens.

4. The actual production of artificial hybrids and their cytological and morphological analysis.

\section{Hybrid Colonies.}

Several such colonies have been studied in detail by one or both authors and references to them will be found elsewhere in this treatment. The colony designated in our records as "Oakhill" may be taken as an example. It is located a few miles from Austin, Texas, near the Oakhill Road and was visited in January 1932 in company with Dr. B. C. Tharp of the University of Texas. In the edge of a small field stood a small copse of scrubby trees and bushes (mostly hollies and scrub oaks). The field was dry and stony with many plants of Opuntia. Among them and along the adjoining railroad right of way were many plants of typical Tradescantia humilis, not yet in flower but recognizable by their winter rosettes. Well within the wood were typical plants of $T$. canaliculata, also in the rosette stage. Along the margin between the field and the wood were a number of puzzling intermediates. Numerous examples of all three types were collected and forwarded to the greenhouses of the Bussey Institution where they were grown and studied through several successive blooming seasons. When they came into flower they confirmed the diagnosis which had been made from the winter rosettes. Those from the field were $T$. humilis, those from the wood were $T$. canaliculata and those from the border presented varying combinations of the characteristics of the two species, some of them resembling closely the artificially obtained first generation hybrids mentioned below. Cytologically the plants diagnosed as $T$. humilis and $T$. canaliculata had regular reduction divisions with a high percentage of fertile pollen. The intermediates exhibited various cytological abnormalities and had only from 40 to 80 percent of fertile pollen. Over 30 plants in all were subjected to a detailed morphological and cytological analysis. The results of these two diverse methods of approach 
were in complete agreement. All the plants suspected, on morphological grounds, of being hybrids, exhibited irregular reduction divisions and had a low percentage of fertile pollen. All those thought to be either $T$. humilis or $T$. canaliculata were found to have regular reduction divisions and a high percentage of fertile pollen. Data on pubescence, flower color, and pollen sterility for a portion of the plants are presented in Table 1 with similar data for comparison from plants of $T$. canaliculata ("Reflexa") and T. humilis ("N.D. \& D") also collected from the neighborhood of Austin.

The demonstration of sterility in hybrids between $T$. canaliculata and $T$. humilis has important theoretical consequences. Were the natural and artificial hybrids between these two entities as fertile as the parents, it might be possible to interpret them as extreme variants of the same species. The high percentages of sterility discovered in both cases confirmed our previous conclusions, that they were well differentiated species, with a physiological as well as a morphological hiatus between them.

Several other hybrid colonies were studied in much the same fashion, as for instance one at Hillsboro, Missouri where $T$. canaliculata was found to hybridize with $T$. virginiana; one at Beebe, Arkansas where $T$. occidentalis hybridized with $T$. canaliculata. In addition numerous plants sent in by correspondents, particularly by Mr. C. C. Deam and by Dr. Hiram Showalter, were subjected to detailed cytological and morphological inspection. In every case there was complete agreement between the conclusions derived at from the two methods of approach. Those plants suspected on morphological grounds to be of hybrid origin exhibited cytological evidences of hybridity and those plants which were morphologically typical were cytologically regular.

Artificial hybridization. The following artificial interspecific hybrids were made and studied:

Tradescantia canaliculata $\times T$. subaspera

$T$. canaliculata $\times T$. humilis

$T$. canaliculata $\times T$. paludosa

$T$. canaliculata $\times T$. gigantea

$T$. paludosa $\times T$. humilis

$T$. gigantea $\times T$. occidentalis

$T$. hirsutiflora $\times T$. canaliculata 


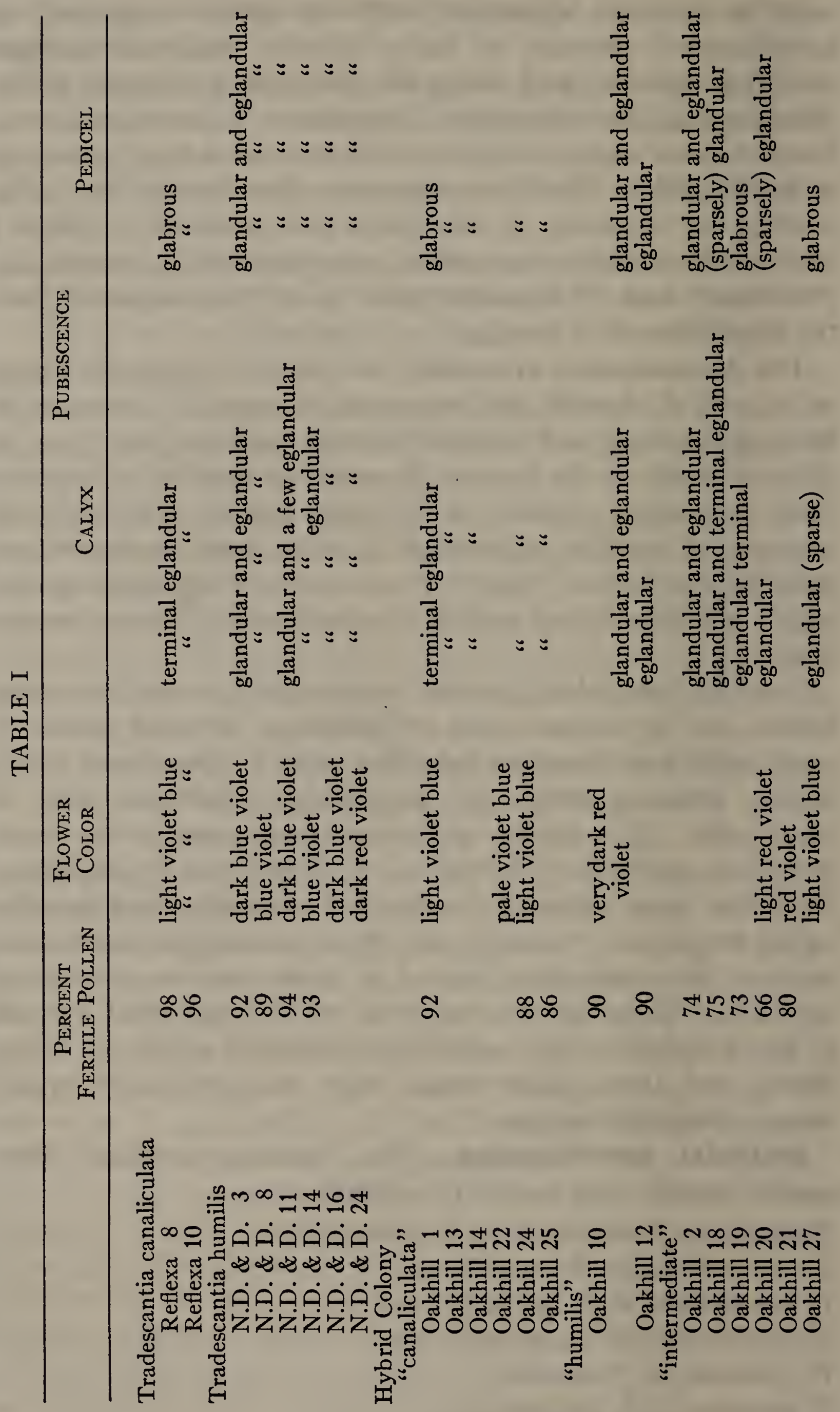


Morphologically all were intermediate between their parental species and resembled the suspected hybrids among the herbarium specimens. It is planned to describe certain cytological and genetical features of these hybrids in a series of technical papers. Four features of taxonomic importance may be discussed here. (1). In hybrids between glabrous species and those with glandular pubescence, the first generation may have scattered eglandular pubescence. From purely morphological considerations eglandular pubescence might not seem to be intermediate between glandular pubescence and none at all, but such has actually proved genetically to be the case. (2). The morphological consequences of inter-specific hybridization in Tradescantia are very much affected by the purely numerical relations between the parents. It will be remembered that for many of the American species, both diploid and tetraploid strains are known in the field, these strains being practically indistinguishable aside from the fact that one has twice as many chromosomes as the other. A series of crosses was made between $T$. canaliculata and $T$. subaspera using both diploid and tetraploid strains of the former. $T$. canaliculata, tetraploid $\times T$. subaspera, tetraploid, gave intermediate hybrids, as might have been expected, and these hybrids were partially fertile. T. canaliculata (diploid) $X$ $T$. subaspera (tetraploid) gave hybrids which superficially looked much more like a peculiar $T$. subaspera than they did like an actual intermediate. This was a not unexpected result since the hybrids had two doses of $T$. subaspera and only one of $T$. canaliculata. They were, furthermore, triploids and were quite sterile. Taxonomically the case is of some consequence since it demonstrates that hybridization between the same pair of species may lead to very different conclusions in different cases. Figure 2 diagrams the possible inter-specific and intra-specific hybrids with $T$. canaliculata and $T$. occidentalis, each of which is known to exist in both the diploid and tetraploid condition (Anderson and Diehl).

In the diagram a letter ("o" for "occidentalis" and "c" for "canaliculata") is used to designate one set of chromosomes. Thus a diploid plant of $T$. canaliculata possesses two such sets and is diagrammed as cc, a tetraploid has four and can be represented as cccc, etc.

With these two strains of $T$. canaliculata and two of $T$. occidentalis it is possible to make two intra-specific hybridizations 
and four inter-specific hybridizations. All six are numbered in the accompanying diagram. It will be noted that nos. 2 and 3 , though intra-specific and morphologically indistinguishable from normal members of these species, are triploids and will therefore be sterile for purely numerical reasons. Of the inter-specific hybrids, types 1 and 6 will be intermediate and semi-fertile. Type

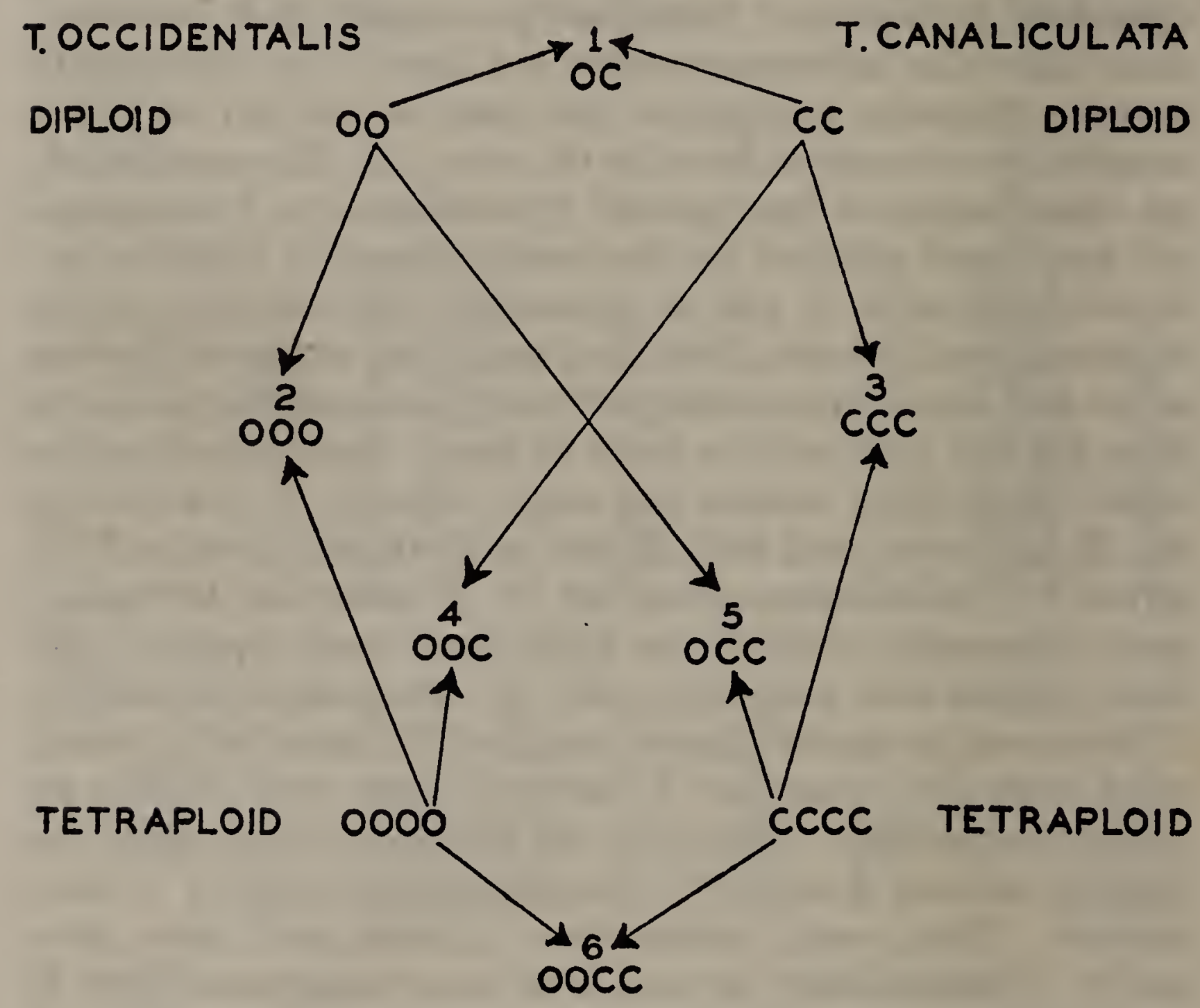

FiguRE 2. Diagram illustrating the six possible types of intra-specific and inter-specific hybrids in Tradescantia occidentalis and Tradescantia canaliculata. Nos. 1 and 6 are semi-fertile; nos. 2, 4, 5, and 3 are sterile; nos. 2 and 3 , though sterile, are intra-specific hybrids. Further explanation in the text.

five will resemble $T$. canaliculata much more than $T$. occidentalis and will be sterile. Type four will resemble $T$.occidentalis much more than $T$. canaliculata and will be sterile. If it does nothing else figure 2 must certainly demonstrate the importance of a knowledge of chromosome numbers in interpreting those specific relationships which might otherwise seem chaotic and inconsistent. 
4. The triploid hybrids were sterile or nearly so. The diploid and tetraploid hybrids were semi-fertile, but with a much lower percentage of fertile pollen than characterized the parental species.

The experimentally produced hybrids have also demonstrated that back-crosses between the hybrids and either of the parental species might be very difficult to recognize in the field. Tradescantia canaliculata and $T$. subaspera crossed back to $T$. subaspera has the appearance of a rather peculiar $T$. subaspera but might not suggest the influence of $T$. canaliculata if one did not know the history of the plant. This point is important since most of the hybridization taking place in nature is under conditions which favor the production of just such back-crosses. Ordinarily when species " $\mathrm{A}$ " and species " $\mathrm{B}$ " meet in nature one of them is very greatly in the majority and the hybrids which occasionally are produced will for the most part be crossed back to the abundant species. Under such conditions the germplasm of one species might become quite extensively "infected" with a small amount of that of the other without any very great morphological effect. An apparent case of this sort is to be found in Tradescantia occidentalis (figure 3 ). Outside the range of $T$. canaliculata this species has only glandular pubescence, though it may vary greatly in amount, from the glabrous or practically glabrous $T$. occidentalis var. scopulorum to the densely pubescent plants from Nebraska and the Dakotas. T. canaliculata is glabrous with a tuft of eglandular hairs at the tips of the sepals. Within the area where the two species overlap, hybrid colonies are occasionally found, as for instance that at Beebe, Arkansas, described below under $T$. occidentalis. Even more noteworthy is the fact that all the plants of $T$. occidentalis which have been carefully examined from within this territory will show at least an occasionally terminal eglandular hair (or in some cases a strongly developed tuft of them) at the tip of the sepal. This would seem to demonstrate that in the area where the two species overlap, $T$. occidentalis has become very extensively "infected" with a small proportion of germplasm from $T$. canaliculata. Civilization is favoring the intermixture in various ways and it is not impossible that in this area within a century these two species may lose their identity.

The codes of botanical nomenclature are nowhere more ineffectual than in their treatment of hybrids. The international 
code as recently modified ${ }^{1}$ has established the following provisions for intrageneric hybrids:

Sect. 6, Art. 31. "Hybrids or putative hybrids between species of the same genus are designated by a formula and, whenever it seems useful or necessary, by a name.

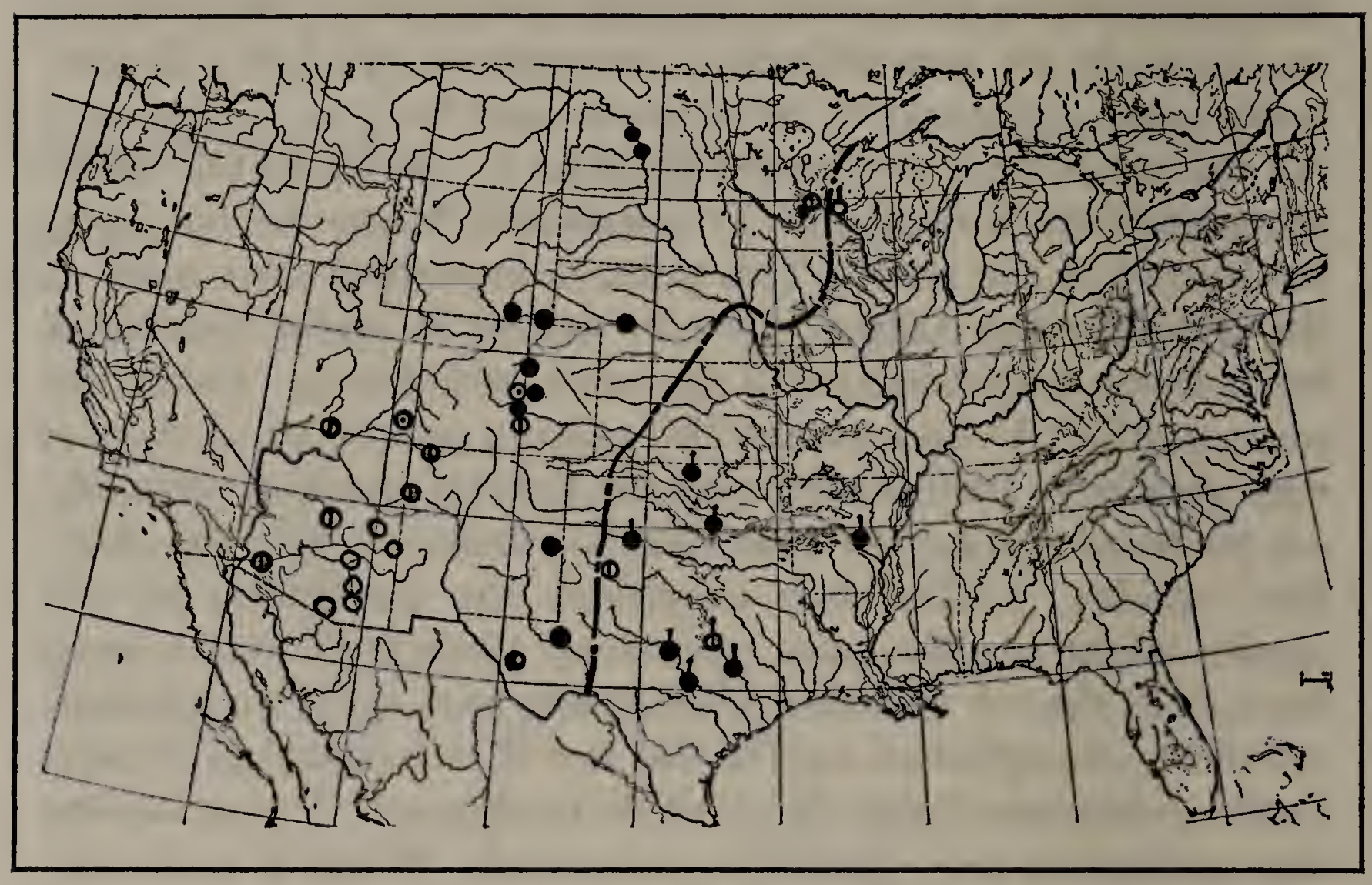

FIGURE 3. Map2 showing variation in pubescence in Tradescantia occicentalis in relation to the range of $T$. canaliculata. Broken line indicates approximate western limit of $T$. canaliculata. The color of the circle indicates degree of pubescence (solid black, heavy; vertical bar, medium; central dot, scatcered hairs; open circle, glabrous). An upright line above the circle indicates terminal eglandular pubescence of the sepal, a character apparently derived from extensive admixture with $T$. canaliculata.

"(1) Sexual hybrids.- The formula consists of the names or specific epithets of the two parents in alphabetical order and connected by the sign $X$. When the hybrid is of known experimental origin, the formula may be made more precise by the addition of the signs $\& o^{x}$ the name of the female (seed bearing) plant being placed first.

"The name, which is subject to the same rules as names of species, is distinguished from the latter by the sign $X$ before the name: e.g. X Salix capreola (Salix aurita Caprea)."

${ }^{1}$ International Rules of Botanical Nomenclature, ed. 3. 9 (1935).

2The authors are indebted to J. Paul Goode and the University of Chicago Press for the base map used throughout this paper. 
These regulations appear simple upon the surface, and are doubtless practicable under controlled conditions, particularly in experimental horticulture, as the phraseology suggests. In taxonomy generally, however, a growing recognition of natural hybridization has become disconcertingly complicated by the limitations of the herbarium, and even field study. Recognition of hybrids in the herbarium often can be scarcely better than a suspicion.

In the field one expects to find both parents in proximity to the hybrid offspring, although such need not always be the case. Even should both parents be found accompanied by intermediate plants which might logically be interpreted as hybrids, furthermore, it must be borne in mind that the combined population will be rarely divisible, for example, into " $\mathrm{X}$ " individuals, " $\mathrm{Y}$ " individuals, and exactly intermediate "XY" individuals. Many individuals roughly classifiable as "XY" will be somewhat more like " $\mathrm{X}$ " or " $\mathrm{Y}$ " than the equalized formula would suggest, and in fact an indistinguishably intergrading series of individuals may obtain between extreme " $\mathrm{X}$ " and extreme " $\mathrm{Y}$ ". Coupled with such phenomena, the natural result of a multiple factor cross, we are confronted with the disquieting thought that not all of the "X" and "Y" plants may be pure genetically, although they may appear so superficially, due to dominance of factors and segregation in the $F_{2}$ or succeeding generations. It is not surprizing that the taxonomist is frequently at a loss to detect and properly designate plant hybrids. The process, under present practices and criteria, amounts virtually to guessing in most instances, and can be little better.

Since the taxonomic treatment of natural hybrids is beset with such difficulty, no attempt has been made to deal with them adequately in this paper. In the annotation of herbarium specimens, a qualified opinion of putative hybridity has frequently been expressed by the writers. In the succeeding taxonomic section of this paper, it will be found that no provision has been made for possible hybrids in either the key to species, in the descriptions, or in the citation of specimens. Citation of apparent hybrids has been avoided in general. However, it is doubtless necessary to provide in some way for the numerous "intermediates" bound to be encountered in both the herbarium and the field; and for that purpose a list of putative and experimental species hybrids follows which includes a very short de- 
scription in terms of characteristics of the parental stocks. No statement is made concerning distribution except in localized instances, and no specimens are cited for obvious reasons. The hybrids will naturally be expected within the ranges of the parent species; citation of such specimens is open to a degree of difficulty and inexactitude which argues against its inclusion. An asterisk preceeds putative hybrids observed in the field accompanied by both supposed parents.

\section{PUTATIVE HYBRIDS}

*Tradescantia subaspera $\times$ virginiana

Rare. Plants adopt the general aspect of $T$. Ernestiana. Leaves broader than in $T$. virginiana and with fewer stomata upon the upper surface. Occasionally found in cultivation.

*T. Ernestiana $\times$ ozarkana

Occasional in Barry County, Missouri. Leaves somewhat narrower than in T. ozarkana, and plants about the size of T. Ernestiana. Sepals somewhat foliaceous as in the latter; pubescence both glandular and eglandular.

* $T$. canaliculata $\times$ subaspera

Frequent. Plants tend toward a somewhat flexuose stem system with leaves somewhat broader and shorter than in T. canaliculata. With something of the pallor of the latter. Sepals glabrous, or with hairs scattered generally, or barbate at the tips. Both varieties of $T$. subaspera are capable of this cross. Hybrids with $T$. subaspera var. typica resemble var. montana to some extent.

${ }^{*} T$. canaliculata $\times$ virginiana

Frequent. Habit of plants generally as in $T$. canaliculata, but with broader foliage and with calyx generally and rather sparsely eglandular pubescent. Simulates to some extent the technical characters of non-glandular individuals of $T$. hirsutiflora in the Gulf States.

T. canaliculata $\times$ hirsutiflora

Occasional. Eglandular pubescent calyx and glabrous or nearly glabrous stems.

T. canaliculata $\times$ gigantea

Rare in Texas. Bracts pouched but glabrous, more laminate than in true $T$. gigantea; sepals and calyx glabrous or essentially so. 
* T. canaliculata $\times$ longipes

Rare in southeast-central Missouri. Habit somewhat as in $T$. longipes, but with a manifest stem and longer, subglaucous foliage; sepals hyaline, and only slightly suffused with rose.

* T. canaliculata $\times$ humilis. Discussed above (pp. 32-34).

* $T$. occidentalis $\times$ canaliculata

Frequent. Notes upon this cross are given on pp. 35-38 and $107-108$.

T. canaliculata $\times$ rosea (?)

This cross would scarcely appear possible in view of the profound distinction of the rosea and canaliculata plexi. The supposition is based upon $R$. M. Harper 1370, with duplicates in the principal American herbaria. The specimen may represent a new species. Attempts to reproduce the cross artificially were unsuccessful.

$T$. hirsuticaulis $\times$ virginiana

Infrequent in northern Alabama. Plants with broad foliage and foliaceous sepals pale yellowish green or very slightly suffused with rose as in $T$. hirsuticaulis. Stem shorter than in $T$. virginiana and calyx not inflated as in that species. Plants collected by Dr. H. M. Showalter in the Sand Mountain region near Muscle Shoals may have resulted from this cross or from $T$. hisuticaulis $X$ canaliculata since they were taller and had sepals very strongly suffused with rose. Upon cytological examination they showed the irregular reduction divisions and poor pollen which characterize hybrids. $T$. hirsuticaulis throughout most of its range is a diploid species while those other species with which it comes into contact are tetraploids, thus forming a natural barrier. It also has an early blooming season, its flowers being nearly gone by before those of $T$. canaliculata and $T$. subaspera appear.

$T$. bracteata $\times$ canaliculata

Plants somewhat shorter than typical $T$. canaliculata, with less of the pallor of that species, and something of the bright greenish yellow shade of $T$. bracteata. The sepals, generally, but sparsely, pilose. Evidently wholly eglandular in our specimens. Occasional in central Iowa. 
T. hirsutiflora $\times$ paludosa

Plants suggesting this relationship were sent to the writers by Miss Anna L. Haas from the vicinity of New Orleans, La., where $T$. paludosa is very frequent and $T$. hirsutiflora is occasional. The plants are somewhat larger than the former, but with the same general habit. The leaves are somewhat larger and narrower with stomata occasional upon the upper surface. The sepals and pedicels are sparsely eglandularpilose.

T. bracteata $\times$ Tharpii

Widespread in central Kansas. Habit generally as in $T$. Tharpii, but frequently with narrower foliage and more manifest stem. Characterized by the occurrence of more or less numerous glandular hairs interspersed amongst the long, non-glandular trichomes. Tradescantia bracteata and $T$. Tharpii reach their southern and northern limits respectively in central Kansas, the former extending to Cowley County, upon the Oklahoma border and the latter to Washington County, upon the border of Nebraska. From present records, largely obtained through the collections of the Kansas State Agricultural College, T. Tharpii is known in its typical form from Clay, Cloud, Cowley, Douglas, Ottawa and Washington counties, and typical T. bracteata from Bourbon, Brown, Butler, Clay, Cloud, Cowley, Edwards, Franklin, Geary, Kearney, Labette, Lyon, Montgomery, Osage, Osborne, Riley, Rooks, Saline, Sedgwick, Shawnee, Wabaunsee, Washington, and Wyandotte counties. The putative hybrid has been collected in Cloud, Ellsworth, Saline, and Washington counties.

$T$. humilis $\times$ occidentalis

Frequent in southeastern Texas. Plants somewhat larger than in $T$. humilis, with indefinitely pubescent stems and eglandular hairs occasional among the densely glandular indument of the calyx and sepals. The status of these plants appears rather difficult of solution. Within the range of the two supposed parents the putative hybrids are relatively frequent and appear to constitute a recognizable element of the flora, according to Prof. B. C. Tharp. Anderson is inclined to agree with Tharp on the basis of breeding and cytological experience. To Woodson, the plants appear mani- 
festly intermediate between the supposed parents, and to recall forcibly the hybrids of $T$. canaliculata $\times$ occidentalis encountered by him in several localities in central Arkansas (cf. pp. 107-108), and evidently frequent in the eastern half of Texas.

\section{STUDY MATERIAL}

The writers have been extremely fortunate in having herbarium material placed at their disposal from several of the most important collections in America. These specimens have been rather fully cited in the subsequent systematic section by means of the following parenthetical abbreviations:
(Ark) University of Arkansas, Fayetteville
(ANSP) Academy of Natural Sciences, Philadelphia, Pa.
(C)
(CM)
Cornell University, Ithaca, N. Y.
(D) Herbarium of Mr. C. C. Deam, Bluffton, Ill.
Carnegie Museum, Pittsburgh, $\mathrm{Pa}$.
(G) Gray Herbarium of Harvard University, Field Museum of Natural History, Chicago, Ill.
(I) University of Iowa, Iowa City
(K) University of Kansas, Lawrence
(KSAC) Kansas State Agricultural College, Manhattan
(LSU) Louisiana State University, Baton Rouge
(MBG) Missouri Botanical Garden, Saint Louis
(Mich) University of Michigan, Ann Arbor
(Mo) University of Missouri, Columbia
(MSC) Michigan State College, East Lansing
(NC) University of North Carolina, Chapel Hill
(NE) New England Botanical Club, Cambridge, Mass.
(NY) New York Botanical Garden, New York City
(NYSM) New York State Museum, Albany
(O) Oberlin College, Oberlin, Ohio
(OSU) Ohio State University, Columbus
(P) Herbarium of Mr. E. J. Palmer, Jamaica Plain, Mass.
(PBC) Philadelphia Botanical Club, Philadelphia, $\mathrm{Pa}$.
(PC) Pomona College, Claremont, Cal.
(RM) Rocky Mountain Herbarium, Laramie, Wyoming
(T) University of Texas, Austin
(TU) Tulane University, New Orleans, La.
(UA) University of Arizona, Tucson
(UC) University of California, Berkeley
(UK) University of Kentucky, Lexington
(UM) University of Minnesota, Minneapolis
(UN) University of Nebraska, Lincoln 


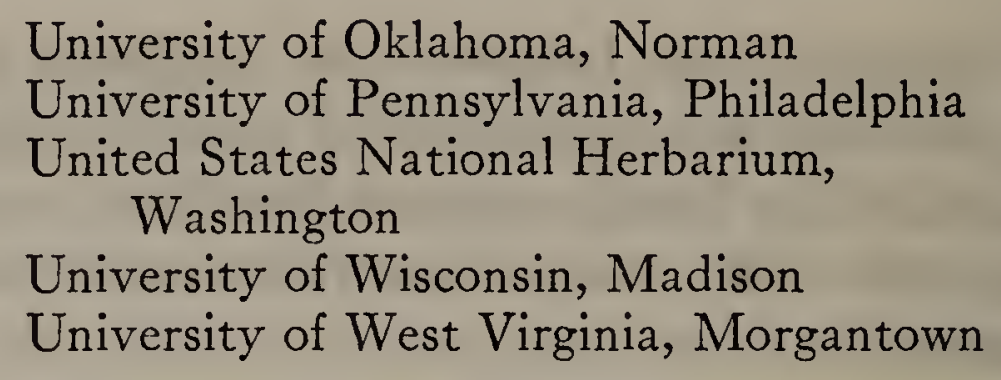

The writers wish to express to the curators of the herbaria enumerated above, as well as to many other friends, appreciation for innumerable instances of aid and good will. In addition to the study of herbarium material, living plants have been extensively grown and intimately studied in experimental grounds at the Bussey Institution of Harvard University and the Missouri Botanical Garden. Field observations have also been made in numerous localities of special interest. Although the frequent reference in the systematic section to the condition of living plants may be criticised, the biological foundation of such observations can scarcely be questioned, and their indispensibility to an adequate understanding of the species of Tradescantia will be affirmed by all students of the genus.

\section{TA XONOMY \\ TRADESCANTIA [Rupp.] L.}

Sepals 3, separate, equal, more or less concave or navicular, foliaceous, petalaceous, or hyaline. Petals 3, separate, equal, ephemeral. Stamens 6 , fertile, equal, hypogynous; anther sacs in our species reniform, dehiscing longitudinally, united by a broadly trapezoid connective; filaments in our species abundantly pilose. Ovary 3-locular; ovules 3-6, uniseriate, orthotropous; style filiform; stigma capitate. Capsule dry, loculicidally 3-valved; seeds naked, roughly oblongoid, subtrigonal, or subspherical, more or less rugose and radiately ridged, the micropyle persistently pitted, the funicular scar linear to punctiform.-Subsucculent, perennial herbs. Stem erect to trailing, herbaceous, frequently producing subterranean stolons. Leaves alternate, linear to oblong-elliptic in our species, sessile, the blade basally produced into a perfoliate sheath. Inflorescence an umbellate, dichotomous, helicoid cyme, terminal or lateral, subtended by 2 , or infrequently 3 , subequal or unequal, foliaceous, or rarely scarious bracts; pedicels subtended by solitary or paired, hyaline or slightly foliaceous bracteoles. 
Tradescantia [Rupp.] Linnaeus, Sp. Pl. 288 (1753); Gen. Pl. ed. 5, 139 (1754). - Bentham \& Hooker, Gen. Pl. 3: 853 (1876). - C. B. Clarke in DC. Monogr. 3: 287 (1881) in part, as to $\S$ Eutradescantia. - Bush in Trans. Acad. Sci. St. Louis, 14: 181 (1904). - Brückner in Engler \& Prantl, Nat. Pflanzenfam. ed. 2. 15a : 166 (1930).

Ephemerum [Tournefort] Moench, Meth. 237 (1794).

Cuthbertia Small, Fl. Southeast. U. S. ed. 1, 237 (1903); ed. 2, 237 (1913).

Type Species: Tradescantia virginiana Linnaeus, Sp. Pl. 288 (1753).

\section{KEY TO THE SPECIES*}

A. Stems erect or ascending, more or less diffuse in certain species, not rooting at the nodes; sepals more or less concave, but not definitely keeled.

B. Bracts very conspicuous, more or less similar to the leaves; seeds roughly oblongoid, the funicular scar linear.

C. Leaf blade broader than the sheath, at least the upper.

D. Sepals $0.4-1.0 \mathrm{~cm}$. long, not inflated, not conspicuously foliaceous.

E. Leaf blade constricted into a subpetiolar base conspicuously narrower than the sheath; stems usually conspicuously flexuose; capsules $0.4-0.6 \mathrm{~cm}$. long.......1. T. subaspera

EE. Leaf blade directly constricted into the sheath; stems not conspicuously flexuose.

F. Leaf blade gradually constricted into the sheath, relatively firm in texture, the anastomosing secondary veins not evident in desiccation, not subglaucous; capsules $0.8-1.0 \mathrm{~cm}$. long.

2. T. edwardsiana

FF. Leaf blade abruptly constricted into the sheath, at least the upper, relatively delicate in texture, the anastomosing secondary veins very evident in desiccation, subglaucous; capsules $0.6-0.8$ $\mathrm{cm}$. long ............. T. ozarkana

DD. Sepals $1.0-1.4 \mathrm{~cm}$. long, more or less turgid and inflated, conspicuously foliaceous......4. T. Ernestiana

CC. Leaf blade narrower than the sheath, or about as broad.

D. Sepals eglandular-pubescent throughout, or glabrous, or merely eglandular-barbate at the tips.

E. Sepals more or less pubescent generally.

*Attention is directed to the list of experimental and supposed hybrids (pp. 40), and to the general discussion of hybridization (pp. 31), which will be found helpful in the interpretation of critical specimens in many instances. 
F. Bracts not conspicuously saccate, the blades well-developed, glabrous to more or less pilose.

G. Stems $0.5-3.5 \mathrm{dm}$. tall, glabrous, or rarely somewhat puberulent above; leaves relatively delicate in texture, never edged with purple; sepals rather delicately foliaceous, bright green, never florid, more or less turgid and inflated..5. T. virginiana

GG. Stems $1.2-4.9 \mathrm{dm}$. tall, more or less pilose or hirsute, infrequently glabrate; leaves relatively firm in texture, usually edged with purple; sepals relatively firm, dull green to more or less florid, particularly after anthesis, scarcely inflated.

6. T. hirsutiflora

GGG. Stems $0.2-0.7 \mathrm{dm}$. tall in bloom, as tall as $3 \mathrm{dm}$. in fruit, pilose to villous; leaves relatively firm in texture, usually edged with pink or purple; sepals somewhat petalaceous, usually strikingly florid, occasionally pale green, not inflated.

7. T. Tharpii

FF. Bracts conspicuously saccate, the blades greatly reduced, densely and minutely velutinous..........8. T. gigantea

EE. Sepals glabrous (see also 18-19), or only the tips eglandular-barbate.

F. Plants strikingly glaucous; leaf blade much narrower than the sheath, not constricted into a subpetiolar base.

9. T. canaliculata

FF. Plants green to subglaucous; leaf blade about as broad as the sheath, or scarcely narrower, at least the upper, constricted into a narrower, subpetiolar base.

10. T. paludosa

DD. Sepals glandular-pubescent, at least in part, rarely glabrate.

E. Sepals with both glandular and eglandular hairs interspersed.

F. Plants erect or ascending; stems simple, or branching infrequently; roots relatively long and slender (except in 14). 
G. Plants bright (usually yellowish-) green; stems and foliage glabrous, or rarely minutely puberulent above..........11. T. bracteata

GG. Plants dull green; stems and foliage more or less pubescent generally, infrequently glabrate.

$H$. Foliage rather flaccid and lax, relatively narrow; sepals relatively delicate in texture, predominantly strikingly florid.

I. Stems 1.5-4.0 dm. tall; bracts spreading; pedicels 2-3 cm. long.

12. T. hirsuticaulis

II. Stems $0.2-1.0 \mathrm{dm}$. tall; bracts ascending; pedicels 4-6 $\mathrm{cm}$. long

13. T. longipes

$\mathrm{HH}$. Foliage rather stiff and turgid, relatively broad; sepals relatively firm in texture, predominantly dull green, occasionally more or less florid, particularly after anthesis in 6.

I. Stems spreading-pubescent, infrequently glabrate; roots relatively slender, glabrate, or only slightly grayish-puberulent.

6. T. hirsutiflora

II. Stems densely arachnoidvillous; roots rather stout and fleshy, densely ferruginous-tomentose.

14. T. Reverchoni

FF. Plants more or less diffuse and spreading, stems much branched; roots fleshy and somewhat tuberoid, at least in part.

G. Stems minutely puberulent; leaves stiff and usually somewhat crisped.

15. T. humilis

GG. Stems arachnoid-pilose; leaves relatively flaccid and lax.

16. T. subacaulis 
EE. Sepals glandular-pubescent throughout, or with a few eglandular hairs at the tips, rarely glabrate.

F. Plants bright (usually yellowish-) green, never glaucous or subglaucous; sepals with rather long, lax glandular hairs, always interspersed with some eglandular, at least at the tips......11. T. bracteata

FF. Plants pale green, glaucous or subglaucous; sepals with rather short, stout, glandular hairs, rarely with a few eglandular at the tips.

G. Roots not tuberiferous.

H. Stem and foliage pubescent, infrequently glabrate; plants subglaucous; funicular scar about as long as the seed.

17. T. roseolens

HH. Stem and foliage absolutely glabrous.

I. Plants glaucous; stems branching; funicular scar about as long as the seed.

18. T. occidentalis

II. Plants subglaucous; stems simple; funicular scar much shorter than the seed . . . 19. T. Wrightii

GG. Roots tuberiferous; stems minutely scabridulous; funicular scar much shorter than the seed......20. T. pinetorum

BB. Bracts extremely inconspicuous, scarious or only slightly foliaceous; seeds compressed-subspherical, the funicular scar punctiform..................... 21. T. rosea

AA. Stems creeping or trailing, rooting at the nodes, at least in part; sepals with a definite, puberulent keel.......22. T. micrantha

\section{Tradescantia subaspera Ker-Gawler}

Roots relatively slender, only slightly fleshy, not persistently pilose, or very inconspicuously and irregularly so; stems erect or ascending, relatively stout, straight, or more or less flexuose, 3-8 dm. tall, shaggy-pilose to glabrate; nodes 4-10; internodes successively shorter from the base, $2-24 \mathrm{~cm}$. long; leaves firmly membranaceous, dark green, not glaucous, the blade ellipticlanceolate, acuminate, constricted into a subpetiolar base, 6-25 $\mathrm{cm}$. long, $1.0-5.0 \mathrm{~cm}$. broad, glabrous, or more or less scatter- 
ingly puberulous, margin ciliolate, stomata predominantly restricted to the lower surface, the sheath $0.5-5.0 \mathrm{~cm}$. long, $0.8-$ $4.0 \mathrm{~cm}$. broad; cymes umbellate, few- to several-flowered, terminal, usually also lateral at the upper nodes; bracts foliaceous, 4-17 cm. long, $0.6-3.0 \mathrm{~cm}$. broad, widely spreading; pedicels $1.0-1.7 \mathrm{~cm}$. long, reflexed and somewhat accrescent in fruit, green, or more or less suffused with purple, pilosulose to glabrate, sepals elliptic, acute to acuminate, $0.4-1.0 \mathrm{~cm}$. long, green, or flushed with purple, not inflated, uniformly glandular- or eglandular-pubescent, or with glandular and eglandular hairs interspersed, infrequently glabrate; petals broadly ovate, 1.0-1.5 $\mathrm{cm}$. long, light to deep blue, rarely white; filaments abundantly pilose, connective broadly trapezoid; ovary ovoid, glandular- or eglandular-pubescent, or with glandular and eglanduiar hairs interspersed, occasionally glabrous; capsules obovoid-trigonal, $0.4-0.6 \mathrm{~cm}$. long; seeds roughly compressed-oblongoid, $0.2-$ $0.3 \mathrm{~cm}$. long, the funicular scar linear, about as long as the seed.

Stems usually more or less conspicuously flexuose above; uppermost lateral cymes sessile, or nearly so; western extensions of the Appalachian Plateau from western West Virginia and central Kentucky and Tennessee to central Illinois and Missouri....................var. typica

Stens straight, or only slightly flexuose above; uppermost lateral cymes usually peduncula te throughout; southern Appalachian Mountains from southwestern Virginia to northern Georgia and Alabama; also locally southward to northern Florida.......................var. montana

la. Tradescantia subaspera Ker-Gawl. var. typica. (Plates II, fig. 1; IV, fig. 1)

Stems usually more or less conspicuously flexuose above, occasionally almost straight, particularly when juvenile or bearing a solitary terminal cyme, 4-8 dm. tall; nodes 6-10; internodes 2-22 cm. long, the uppermost usually greatly reduced; cymes rarely terminal only, predominantly also lateral, the uppermost sessile, or subsessile, and the successively lower with increasingly evident peduncles.

Tradescantia subaspera Ker-Gawler in Bot. Mag. 39: 1597 (1813).

Tradescantia cristata Walter, Fl. Carol. 119 (1788), nec L., nec alior.

Tradescantia pilosa J. G. C. Lehmann, Ind. Sem. Hort. Hamb. 16 (1827);

Nov. Act. Nat. Cur. $14^{2}: 822$ (1829). - Small in Bull. Torrey Bot. Club, 24: 236 (1897). - Britton, Man. Fl. 242 (1901). - Robinson \& Fernald, in Gray, Man. ed. 7. 264 (1908). - Britton \& Brown, Ill. 
Fl. ed. 2, 1: 462 (1913). - Small, Fl. Southeast. U. S. 240 (1903). -

Brückner in Engler \& Prantl, Nat. Pflanzenfam. ed. 2, 15 ${ }^{a}: 166$ (1930). - Rydberg, Fl. Prairies \& Plains, 200 (1932).

Tradescantia flexuosa Rafinesque, Atl. Jour. 1: 150 (1832).

Tradescantia axillaris Rafinesque, New Fl. 2: 87 (1836).

Tradescantia axillaris Rafinesque var. flexuosa Rafinesque, loc. cit. (1836).

Tradescantia Virginica L. $\beta$ pilosa (Lehm.) C. B. Clarke in DC. Monogr. 3: 291 (1881).

Tradescantia villossima Fraser ex C. B. Clarke, loc. cit. (1881), in synon. Tradescantia Virginica L. var. flexuosa (Raf.) S. Watson in Proc. Amer. Acad.n.s. 18: 168 (1883). - Watson \& Coulter in Gray, Man. ed. 6.539 (1890).

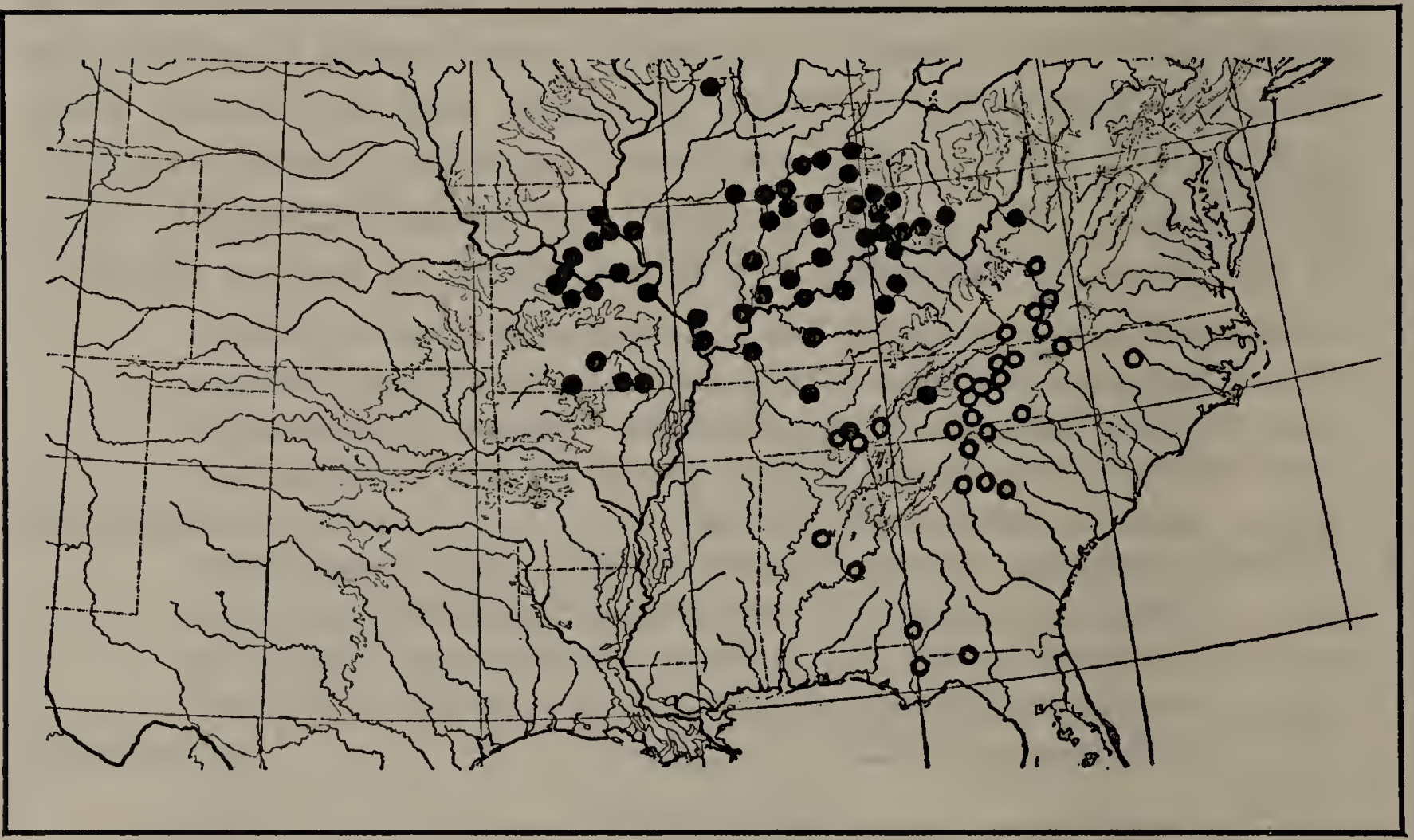

Map 1. Range of Tradescantia subaspera var. typica (O) and var. MONTANA (O)

Woods and thickets, occasionally spreading into fields and roadsides, western extensions of the Appalachian Plateau from western West Virginia, and central Kentucky and Tennessee, to central Illinois and Missouri.

MaP 1.

West Virginia: on boulder, Burning Springs, Wirt Co., July 3, 1890, Millspaugh s.n. (NY).

Oнго: common in woodlands of Twin Twp., Preble Co., Sept. 3, 1929, Hicks s.n. (OSU); Paint Creek Gorge, Ross Co., June 9, 1929, Bartley E Pontius s.n. (OSU); a persistent weed in yards and waste places, Hillsboro, Highland Co., June 19, 1922, Roads s.n. (OSU); Montgomery Co., June 14, 1902, Horlacher s.n. (OSU); Loveland, Clermont Co., 1874, James s.n. (OSU); "Fernbank" ad ripas fluminis Ohio prope "North 
Bend," 1843, Short s.n. (G,MBG,NY); near Cincinnati, July 25, 1881, Lloyd s.n. (ANSP,FM,MBG); moist woods, Oxford, June 23, 1910, Overholts s.n. (MBG).

Kentucky: damp wooded bluffs of Dicks [Dix] River, Burgin, Mercer Co., June 5, 1916, King 66 (FM); Lexington, 1842, Short s.n. (G,MBG,NY); Kuttawa, Lyon Co., June 2-18, 1909, Eggleston 4562 (NY); near Barren River, Warren Co., Aug., 1892, Price s.n. (MBG); hills along Green River, Aug. 21, 1895, Rose s.n. (US); Louisville, 1865, Mohr s.n. (US); slope of ravine between Cote Brilliant and Hickory Ridge, north of Owl Creek, s.e. of Newport, June 21, 1907, Cleborne s.n. (UN).

Tennessee: Nashville, May 12-18, 1894, Bicknell s.n. (NY); Knox Co., June 29, 1891, Kearney s.n. (OSU); woods in Cumberland Mts., near Sewanee, Marion Co., June 23, 1929, Leeds 1257 (MBG).

InDIANA: on north side of Wabash River, $1 / 4$ mile e. of Bluffton, Wells Co., July 7, 1905, Deam 19 (D,MBG); Connersville, July 25, 1918, Drushel 3684 (MBG); wooded hillside $1 / 8 \mathrm{mi}$. south of Hartford, Blackford Co., Aug. 3, 1906, Deam 1377 (D,NY); Putnam Co., July 29, 1889, MacDougal s.n. (NY); along Big Four Railroad, $1 / 8$ mile south of Veedersburg, June 4, 1905, Deam s.n. (D); in a woods along Bean Blossom Creek across from Helmsburg, Brown Co., June 16, 1912, Deam 11193 (D); in a woods bordering the artificial lake about 1 mile north of Jasper, Dubois Co., July 2, 1912, Deam 11570 (D); wooded bank of Prairie Creek, about $3 \mathrm{mi}$. northeast of Thorntown, Boone Co., June 26, 1927, Deam 44823 (D); in a woods 10 mi. east of Logansport, Cass Co., July 23, 1915, Deam 17880 (D); base of rocky hill near Stop 41, about 1 mi. east of Harmony, Clay Co., July 30, 1913, Deam 13885 (D); in woods about $1 / 4$ mile east of Wilson Creek, and 1 mile north of traction line, Dearborn Co., June 26, 1910, Deam 6873 (D); wooded bluff of White River between Lawrenceport and River Vale, Lawrence Co., July 13, 1915, Deam 17308 (D); in a moist woods along White River about $8 \mathrm{mi}$. north of Indianapolis, locally known as "Crow's Nest," Marion Co., July 2, 1913, Deam 13534 (D); in a woods $3 \mathrm{mi}$. west of Peru, July 23, 1915, Deam 17893 (D); wooded ravine 3 mi. south of New Harmony, Posey Co., July 4, 1915, Deam 16827 (D); wooded bluff of Ohio River about 5 mi. east of Cannelton, Perry Co., June 29, 1915, Deam 16630 (D); in an oak and maple woods about $2 \mathrm{mi}$. northeast of Riley, Vigo Co., July 31, 1925, Deam 41902 (D); wooded hillside along Wabash Valley traction line near Stop 58, Wabash Co., July 7, 1907, Deam 2234 (D); Frankfort, July 18, 1886, Young s.n. (G).

IllinoIs: low rich woods, Shawneetown, Gallatin Co., June 16, 1919, Palmer 15508 (MBG); Pike Co., date lacking, Holton 10707 (MBG); rich bottom-land woods, Makanda, July 22, 1902, Gleason s.n. (G); rich woods, Champaign, June 30,1899, Gleason s.n. (G); "Bird Haven," Richland Co., July 4, 1910, Ridgway s.n. (US); low woods, Crystal Lake, Oct. 25, 1910, Pease 13062 (G); Union Co., July 24, 1873, French s.n. (G).

Missouri: shady hillsides near Hematite, Jefferson Co., July 7, 1891, Eggert s.n. (FM,G,MBG); low rich woods along branch of Tuque Creek, 5 mi. northeast of Marthasville, Warren Co., July 4, 1932, Steyermark s.n. (MBG); along rocky bluffs of river, near Pontiac, Ozark Co., June 28, 
1928, Palmer 34802 (MBG); Riverview Park, damp bluffs, Hannibal, Marion Co., July 3, 1915, Davis 3604 (MBG); Gascondy, Osage Co., July 21, 1914, Emig 215 (MBG,US); rocky slopes below limestone bluffs, along south fork of Salt River, south of Victor, Monroe Co., June 27, 1933, Palmer E Steyermark 40763 (MBG); along rocky wooded bluffs of Eleven Point River, "Irish Wilderness," west of Turner Mill Spring, Oregon Co., July 14, 1933, Palmer Eु Steyermark 41757 (MBG); along limestone bluffs of Salt River, near New London, Ralls Co., June 27, 1933, Palmer Eं Steyermark 40685 (MBG); Hinkson bluffs, Columbia, Sept. 23, 1901, Favor s.n. (Mo); along Osage River bluffs south of Mary's Home, Miller Co., July 5, 1934, Steyermark 13076 (MBG); wooded slopes along Proctor Creek, Morgan Co., July 7, 1934, Steyermark 13196 (MBG); low woods along Current River, below mouth of Buffalo Creek, east of Bennett, Ripley Co., Aug. 6, 1934, Steyermark 14276 (MBG); shaded woods of Roubidoux sandstone ravine, tributary of Big Piney River, $3 \mathrm{mi}$. west of Houston, Texas Co., Sept. 27, 1934, Steyermark 15527 (MBG); rich woods at base of limestone bluffs along Current River, between Powder Mill Ford and Blue Spring, Shannon Co., Oct. 28, 1934, Steyermark 16335 (MBG); Moniteau Co., low wooded slopes below limestone outcrops, along small creek, east of Tipton, April 26, 1935, Steyermark 18820 (MBG).

\section{lb. Tradescantia subaspera Ker-Gawl. var. montana}

(Shuttlew.), comb. nov.

Stems straight, or only slightly flexuose above, 3-7 dm. tall; nodes 4-8; internodes $2-24 \mathrm{~cm}$. long, successively shorter from the base, but usually not as greatly reduced and crowded above as in the typical variety; cymes occasionally terminal only, predominantly also lateral, the uppermost ordinarily with a conspicuous peduncle, and not infrequently equalling the terminal inflorescence.

Tradescantia montana Shuttleworth ex Small \& Vail in Mem. Torrey Bot. Club, 4: 160 (1893). - Britton, Man. Fl. 242 (1901). - Robinson \& Fernald in Gray, Man. ed. 7. 265 (1908). - Britton \& Brown, Ill. Fl. ed. 2. 1: 462 (1913). - Small, Fl. Southeast. U.S., 240 (1903).

Tradescantia comata Small in Bull. Torrey Bot. Club, 24: 234 (1897); Fl. Southeast. U.S., 241 (1903).

Woods, southern Appalachian Mountains from southwestern Virginia to southeastern Tennessee, and northern Georgia and Alabama; also locally southward to northern Florida (Lake Miccousukee, Jefferson Co.).

MAP 1.

VIrginia: White Rock Mt., Smyth Co., June 22, 1892, Britton Britton छ Vail s.n. (NY); East River Mt., Bland Co., date lacking, Core s.n. (NY); Farmer Mt., on New River, alt. 2200 ft., Carroll Co., July 12, 1892, Small s.n. (NY); Narrows, Aug. 3, 1927, W.V.U. 972 (WV).

West Virginia: Fayette Co., 1890-1898, Nuttall s.n. (WV). 
North Carolina: vicinity of Blowing Rock, Watauga Co., July 21, 1890, Heller 179 (ANSP,MBG,NY); north fork of Swannanoa River, at Tyson's Settlement, June 26, 1902, Harshberger 9 (ANSP); Roan Mt. and vicinity, July, 1880, Meehan Porter Leidy E Wilcox s.n. (ANSP); Balsam, Aug., 1896, Williamson s.n. (ANSP); Cedar Cliff Mt., Buncombe Co., June 12, 1897, Biltmore $1037 b$ (G,MBG,NY); near Sunburst, Haywood Co., alt. $4000 \mathrm{ft}$., June, 1911, House 4612 (MBG); in preeruptis reg. med. mont. ad Broad River Mts., June, 1841, Rugel s.n. (NY,TYPE); mountains north of Mt. Airy, June 20, 1909, Rusby s.n. (NY); Pilot Mt., 1851, Gibbes s.n. (NY); between Marshall and Asheville, July 1, 1872, Faxon s.n. (G); meadow, Lynn, Polk Co., May 20, 1899, Churchill s.n. (G); woods, Pigeon Gap, Pisgah Forest, alt. $4500 \mathrm{ft}$., July, 1908, House 3659 (G); summit of Stone Mt., Caldwell Co., July 31, 1891, Small E Heller s.n. (FM); on top of White Side Mt., Highlands, Aug. 31, 1932, Coker s.n. (NC); Lynch's farm, Green Hill, June 17, 1887, Lynch s.n. (NC); Frank, Mitchell Co., June 8, year lacking, Ashe s.n. (NC); moist soil, Arboretum, Chapel Hill, July 26, 1931, Webb s.n. (NC); Linville Gorge, Burke Co., Aug. 17, 1923, Alexander s.n. (NC).

South Carolina: on dry cliffs, Rocky Spur Mt., Greenville Co., Sept. 6, 1921, Peattie 1465 (G); Andersonville, 1886, Gibbes s.n. (NY); summit of Paris Mountain, July, 1896, Small s.n. (NY); Seneca, 1888, McCarthy s.n. (O).

Georgia: Rome, date lacking, Chapman s.n. (MBG); Wilkes Co., "Mts. of Georgia," date lacking, Chapman s.n. (NY); rich woods on Germain's Island in Savannah River, Columbia Co., alt. 175 ft., June 7, 1902, Harper 1296 (MBG,NY); rich wooded bluff near Chattahoochee River, below Hilton, Early Co., July 31, 1903, Harper 1907 (FM,G,MBG,NY, US); rich woods, Athens, May, 1897, Harper s.n. (NY).

Alabama: River Hills, Elmore Co., Aug. 9, 1899, Earle छ Earle 7 (MBG,NY,US); rocky shaded hill, Birmingham, May 24, 1901, Earle s.n. $(\mathrm{NY})$.

Tennessee: shady woods, Franklin Co., June 7, 1897, Eggert s.n. (MBG); within three miles of Wolf Creek Sta., Aug. 23, 1897, Kearney 922 (MBG,NY,US); Roan Mt., Station, Aug. 28, 1908, Rydberg 8234 (NY); between Sherwood and Anderson, June 7, 1897, Eggert s.n. (MBG); Lookout Mr., Hamilton Co., Aug. 2-6, 1900, Pollard छ Maxon 424 (NY).

FLORIDA: rich woods on northeast side of Lake Miccosukee, Jefferson Co., June 20, 1925, Harper 42 (G,MBG,NY,US); rich soil on slope of ravine by Apalachicola River, Rock Bluff Landing, Liberty Co., Aug. 6, 1927, Wiegand छ Manning 714 (C).

Tradescantia subaspera, in disuse for over one hundred years, is regretfully adopted in place of the familiar $T$. pilosa Lehm. The detailed description and excellent plate submitted by KerGawler leave no room for doubt concerning the identity of his plant, which was collected by Lyon and cultivated in London as early as 1812. This species is the largest of the American species 
of Tradescantia, and is quickly identified by its stout, zigzag stems, and broad, dark green foliage. It frequents rich woods, predominantly, and apparently tolerates soil derived from either limestone or sandstone.

Although puzzling in its morphological intergradations to var. typica, var. montana constitutes a marked geographical variety. In spite of frequent intermediates, it differs varietally from the var. typica in its smaller size in general, straight, or almost straight stem, narrower leaf-blades in relation to the sheaths, and cymes which are solitary and terminal, or lateral with evident peduncles. Juvenile plants of var. typica frequently imitate the aspect of var. montana.

The group of species represented by $T$. subaspera, $T$. ozarkana, and $T$. edwardsiana may well be thought to represent the most "primitive" element of the genus as represented in the United States. Their range in the southern Appalachian highlands, the Ozarks, and the Edwards plateau is the most ancient geologically of the genus, where they are found in company with notable so called "relict" species. Since the Commelinaceae are a predominantly tropical family, morphological characters of the plexus of $T$. subaspera which are similar to, or reminiscent of those widely found in tropical species may also be interpreted as indicators of a primeval nature. Such characters are found in the leaves, the shape and epidermal characters of which are very conspicuously like those of tropical relatives. The restriction of the stomata to the lower surface of the foliage and the orientation of the epidermal cells of the upper leaf surface appear significant in this regard.

\section{Tradescantia edwardsiana Tharp}

(Plate IV, fig. 2)

Roots long and slender, relatively fleshy, very inconspicuously and irregularly pilose; stems erect or ascending, relatively stout, straight, not flexuose, $2.5-7.0 \mathrm{dm}$. tall, densely and minutely puberulent to glabrate; nodes 3-6; internodes $1-11 \mathrm{~cm}$. long; leaves relatively firm, somewhat subsucculent and crisp, light green, not glaucous or subglaucous, the anastomosing secondary veins not evident in desiccation, the blade elliptic-lanceolate, acuminate, gradually constricted into the sheath, $7-30 \mathrm{~cm}$. long, $1.5-4.5 \mathrm{~cm}$. broad, minutely puberulent to essentially glabrate, stomata predominantly restricted to the lower surface, the 
sheath $0.5-3.0 \mathrm{~cm}$. long, $0.7-2.0 \mathrm{~cm}$. broad; cymes umbellate, few- to several-flowered, terminal, usually also lateral at the upper nodes, the lateral inflorescences with a definite peduncle; bracts foliaceous, $4-18 \mathrm{~cm}$. long, $0.6-3.5 \mathrm{~cm}$. broad, widely spreading; pedicels $1.5-3.0 \mathrm{~cm}$. long, reflexed and somewhat accrescent in fruit, green, minutely and densely puberulent; sepals elliptic, acuminate, $0.6-0.9 \mathrm{~cm}$. long, green, not inflated, glandular-puberulent; petals broadly ovate, $1.0-1.2 \mathrm{~cm}$. long, white to pale mauve, rarely bright pink; filaments abundantly pilose, connective broadly trapezoid; ovary ovoid, glandularpuberulent; capsules obovoid-trigonal, $0.8-1.0 \mathrm{~cm}$. long; seeds $0.3-0.4 \mathrm{~cm}$. long, roughly compressed-oblongoid, the funicular scar linear, about as long as the seed.

Tradescantia edwardsiana Tharp in Rhodora, 34: 57, fig. 1 (1932).

Rich woods and along moist alluvial terraces and ravines, south-central Texas.

MAP 2.

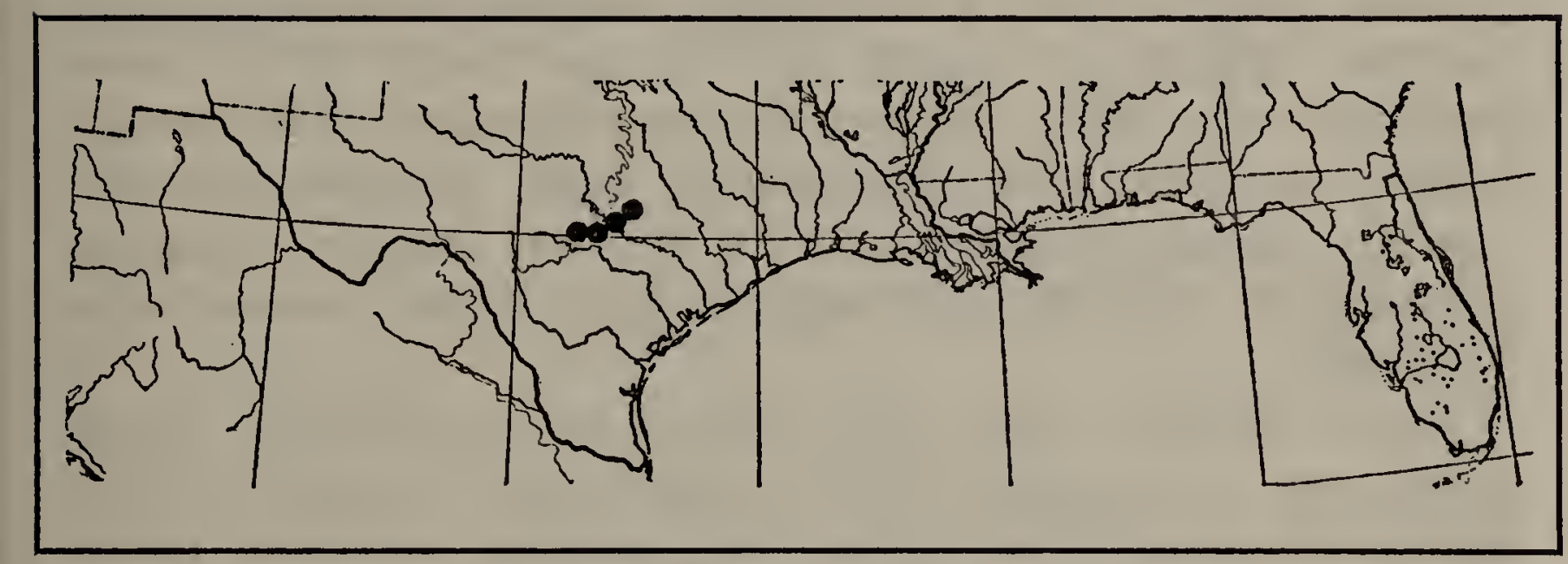

Map 2. Range of Tradescantia edwardsiana.

Texas: on the Blanco River, 7 miles northwest of Kyle, Hays Co., April 4, 1921, Tharp s.n. (T, TYPE); near Bull Creek School, Travis Co., Jan., 1932, Tharp Eं Anderson s.n. (MBG); Temple, date lacking, Pace s.n. (MBG); rich woods, shaded bluffs, Boerne, Kendall Co., April 6, 1917, Palmer 11475 (G,NY); mountains above Austin, May, year lacking, Wright s.n. (G).

An interesting southwestern counterpart of the southern Appalachian $T$. subaspera, which it closely simulates in both habitat and general habit, but differing from it sharply in superficial aspect in that the nodes are not as markedly reduced upwards as in the latter species. Further remarks upon this species in comparison to T. ozarkana follow. 
3. Tradescantia ozarkana, sp.nov.

(Plate XII)

Planta habitu $T$. edwardsianam Tharp simulans; radicibus crassiusculis vix pilosis; caulibus erectis strictis vel aliquid geniculatis $1.5-5.0 \mathrm{dm}$. altis glabris vel molliter pilosis; nodis plerisque 4-7; internodiis 2-8 cm. longis; foliis tenuiter subsucculentis dilute viridibus subglaucescentibus venis secundariis reticulatis post exsiccationem in parenchymate clare manifestis, lamina aut ovato- aut lineari-lanceolata acuminata in vaginam basi subito constricta $10-28 \mathrm{~cm}$. longa $1.5-5.0 \mathrm{~cm}$. lata glabra vel margine sparse minuteque ciliolata, vagina $0.5-3.0 \mathrm{~cm}$. longa ca. $0.6-3.0 \mathrm{~cm}$. lata; cymis umbellatis plurifloris terminalibus; bracteis foliaceis $6-15 \mathrm{~cm}$. longis $1.5-4.0 \mathrm{~cm}$. latis patulis vel paulo ascendentibus; pedicellis $2.0-3.2 \mathrm{~cm}$. longis post maturitatem paulo accrescentibus plus minusve dense glanduloso-pilosulis; sepalis ellipticis acuminatis $0.9-1.0 \mathrm{~cm}$. longis paululo foliaceis haud inflatis plus minusve glanduloso-pubescentibus; petalis late ovatis $1.2-1.6 \mathrm{~cm}$. longis dilute roseopurpureis vel albidis; filamentis pilosis, connectivo late trapezoideo; ovario ovoideo plus minusve dense glandulo-puberulo; capsulis pandurato-obovoideis $0.6-0.8 \mathrm{~cm}$. longis; seminibus oblongoideis $0.3-0.4 \mathrm{~cm}$. longis funiculo lineari semen paene aequante.

Roots relatively short and fleshy, not persistently pilose; stems erect or ascending, usually rather stout, straight or very slightly flexuose, $1.5-5.0 \mathrm{dm}$. tall, glabrous to softly pilose; nodes $4-7$; internodes $2-8 \mathrm{~cm}$. long; leaves delicately subsucculent, light green, subglaucous, the anastomosing secondary veins clearly manifest in desiccation, the blade ovate- to linearlanceolate, acuminate, abruptly constricted into the sheath, $10-28 \mathrm{~cm}$. long, $1.5-5.0 \mathrm{~cm}$. broad, glabrous, or the margin sparsely and minutely ciliolate, stomata predominantly restricted to the lower surface, the sheath $0.5-3.0 \mathrm{~cm}$. long, about $0.6-3.0 \mathrm{~cm}$. broad; cymes umbellate, several-flowered; bracts foliaceous, 6-15 cm. long, $1.5-4.0 \mathrm{~cm}$. broad, spreading to slightly ascending; pedicels $2.0-3.2 \mathrm{~cm}$. long, somewhat accrescent after maturity, pale green, more or less densely glandularpilosulose; sepals elliptic, acuminate, $0.9-1.0 \mathrm{~cm}$. long, very slightly foliaceous, not inflated, more or less densely glandularpilosulose; petals broadly ovate, $1.2-1.6 \mathrm{~cm}$. long, pale roselavender to white; filaments abundantly pilose, connective 
broadly trapezoid; ovary ovoid, glandular-puberulent; capsules pandurate-obovoid, $0.6-0.8 \mathrm{~cm}$. long; seeds $0.3-0.4 \mathrm{~cm}$. long, roughly compressed-oblongoid, the funicular scar about as long as the seed.

Rocky, wooded hillsides and ravines, southwestern Missouri, northwestern Arkansas, and extreme eastern Oklahoma (Leflore Co.).

MAP 3.

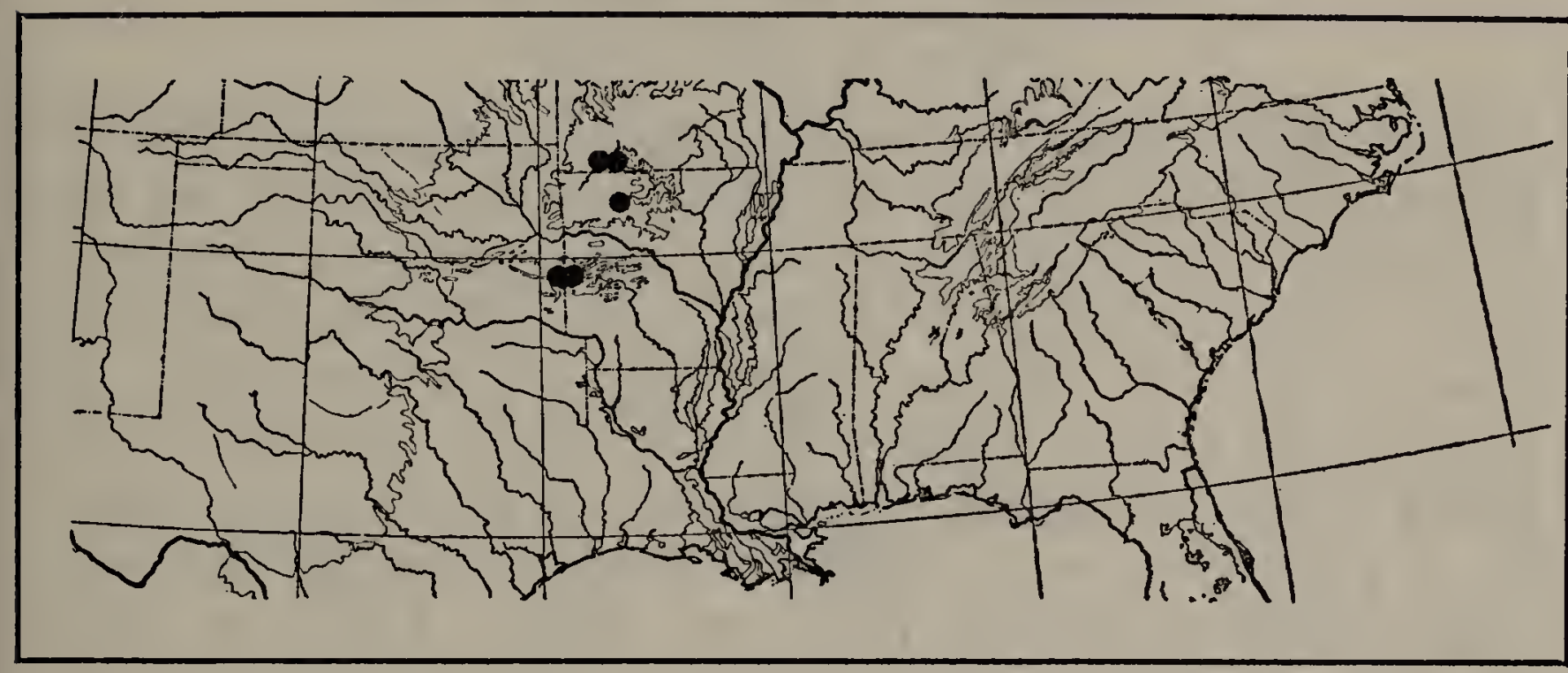

MaP 3. Range of Tradescantia ozarkana.

Missouri: dry, rocky, wooded ravine, "Bruner Hollow," near Roaring River Spring, Barry Co., May 11, 1934, Woodson Hubricht E Steyermark s.n. (FM,G,MBG, tYPE, NY,US); common along river, Eagle Rock, Barry Co., June 18, 1897, Bush 194 (MBG,NY).

Arkansas: rocky wooded hillsides, rich soil, near Jasper, Newton Co., May 7, 1925, Palmer 27066 (MBG,P); slopes of Rich Mountain, northwest of Mena, Polk Co., April 27, 1934, Heinze s.n. (MBG).

OKLAномa: in deep rich coves, moist sandy soil with abundant humus, north slopes of Rich Mountain, near Page, Leflore Co., April 27, 1922, Palmer 20962 (MBG,P); on grassy railroad right-of-way, near Page, Leflore Co., May 10, 1915, Blakley 3440 (MBG).

This species is obviously most closely related to $T$. edwardsiana of south-central Texas. Although specificity was suspected upon examination of herbarium specimens of the Missouri, Arkansas, and Oklahoma plants, the decision was not made to recognise them as distinct from $T$. edwardsiana until living plants were seen. After these had been examined from both Barry County, Missouri and Leflore County, Oklahoma, inclusion of the plants from the Ozarks with those from the Edwards Plateau seemed impossible. The two species evidently differ almost entirely in their foliage as outlined in the key to species. 
The capsules are intermediate in size between those of $T$. subaspera and T. edwardsiana. Although the criticism may be made that such foliar characters alone do not conform with the best traditional taxonomic usage, it can scarcely be denied that the importance of vegetative structures as systematic criteria are coming into their own after a long period of undeserved neglect.

\section{Tradescantia Ernestiana, sp. nov.}

(Plates IV, fig. 5; VIII)

Planta habitu inter $T$. edwardsianam et $T$. virginianam medium tenens; radicibus tenuibus vix pilosis; caulibus erectis vel ascendentibus strictis $2-4 \mathrm{dm}$. altis sparse pilosulis glabrisve; nodis 2-5; internodiis $3-12 \mathrm{~cm}$. longis; foliis membranaceis obscure viridibus, lamina elliptico-lanceolata acuminata in vaginam basi subito constricta 9-25 cm. longa $1.6-4.0 \mathrm{~cm}$. lata glabra vel sparse minuteque puberula, vagina $0.2-3.0 \mathrm{~cm}$. longa $0.6-2.4 \mathrm{~cm}$. lata; cymis umbellatis pauci- vel multifloris terminalibus; bracteis foliaceis $6-17 \mathrm{~cm}$. longis $1.2-3.5 \mathrm{~cm}$. latis patulis; pedicellis $2.0-3.2 \mathrm{~cm}$. longis post maturitatem reflexis sat accrescentibus pilosulis; sepalis ellipticis acuminatis $1.0-1.4 \mathrm{~cm}$. longis foliaceis haud inflatis uniformiter eglanduloso-pubescentibus; petalis late ovatis $1.4-1.5 \mathrm{~cm}$. longis atrocaeruleis rariusve roseis; filamentis pilosis, connectivo late trapezoideo; ovario ovoideo eglanduloso-pubescente; capsulis obovoideo-trigonalibus $0.5-0.7 \mathrm{~cm}$. longis; seminibus oblongoideis $0.2-0.3 \mathrm{~cm}$. longis funiculo lineari semen paene aequante.

Roots relatively long and slender, more or less fleshy, not persistently pilose; stems erect or ascending, straight, $2-4 \mathrm{dm}$. tall, glabrous to sparsely pilosulose; nodes 2-5; internodes 3-12 $\mathrm{cm}$. long; leaves membranaceous, dull green, the blade ellipticlanceolate, acuminate, directly constricted into the sheath, 9-25 cm. long, 1.6-4.0 cm. broad, glabrous to sparsely and minutely puberulent, stomata predominantly restricted to the lower surface, the sheath $0.2-3.0 \mathrm{~cm}$. long, $0.6-2.4 \mathrm{~cm}$. broad; cymes umbellate, few- to several-flowered, terminal, solitary; bracts foliaceous, 6-17 cm. long, $1.2-3.5 \mathrm{~cm}$. broad, widely spreading; pedicels $2.0-3.2 \mathrm{~cm}$. long, reflexed and somewhat accrescent in fruit, pilosulose; sepals elliptic, acuminate, 1.0-1.4 $\mathrm{cm}$. long, foliaceous, somewhat inflated, uniformly eglandularpubescent; petals broadly ovate, $1.4-1.5 \mathrm{~cm}$. long, deep blue, 
rarely rose; filaments abundantly pilose, connective broadly trapezoid; ovary ovoid, eglandular-pubescent; capsules obovoidtrigonal, $0.5-0.7 \mathrm{~cm}$. long; seeds roughly compressed-oblongoid, $0.2-0.3 \mathrm{~cm}$. long, the funicular scar linear, about as long as the seed.

Rocky, wooded hillsides and ledges, extreme southwestern Missouri and adjacent Arkansas and Oklahoma. MaP 4.

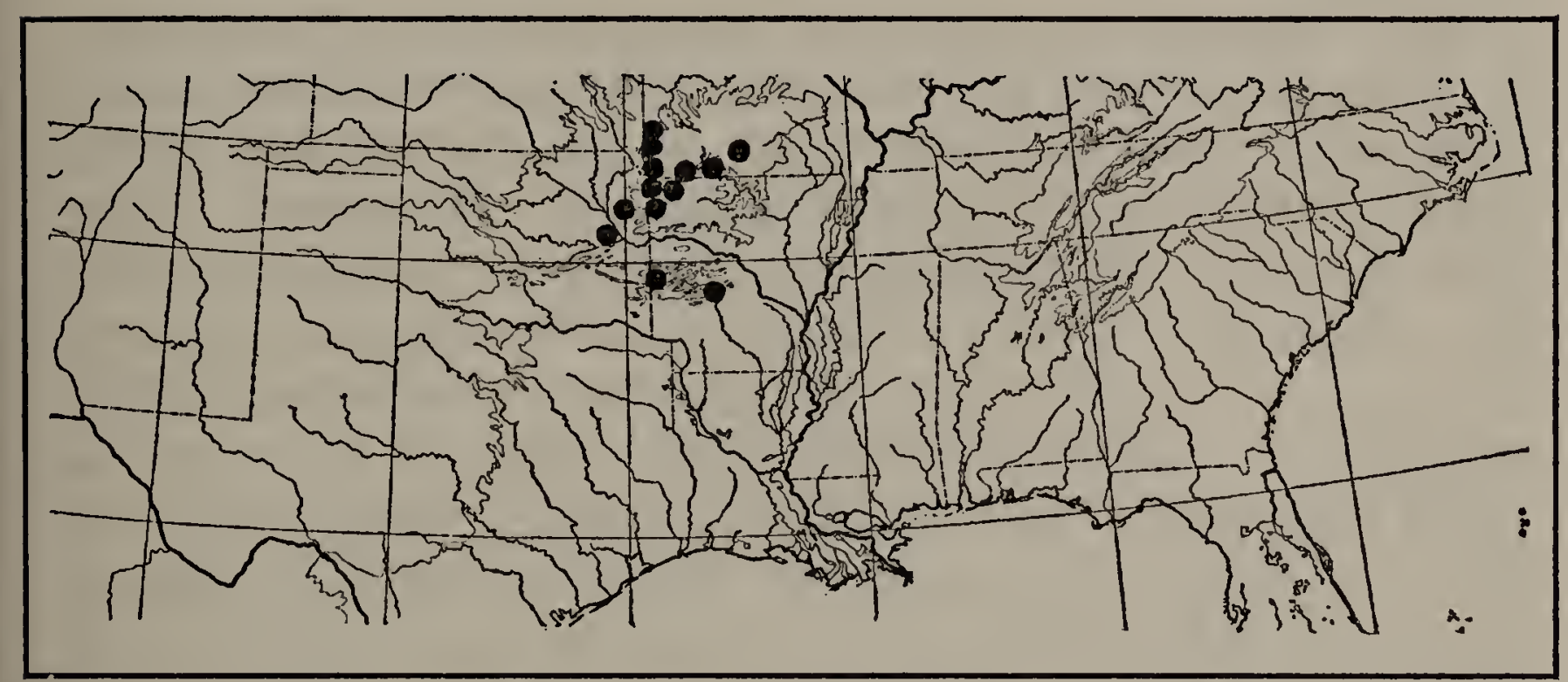

Map 4. Range of Tradescantia Ernestiana.

Missouri: low, sparsely wooded bluffs of Center Creek, about 2 miles below Wilson's Spring Creek, Jasper Co., April 30, 1933, Woodson छ Hubricht s.n. (G,MBG, TYPE, NY,US); rich wooded dolomite slopes along Roaring River, about 4 miles west of Eagle Rock, Barry Co., May 11, 1934, Woodson Hubricht Eे Steyermark s.n. (FM,G,MBG,NY,US); woods, Swan, Taney Co., May 21, 1905, Bush 2939 (MBG); steep limestone ledges, Butler's Bluff, near Noel, McDonald Co., April 30, 1933, Woodson छ Hubricht s.n. (MBG); rich wooded slopes below limestone bluffs, along north fork of White River, between Roosevelt and Richville, Douglas Co., April 7, 1935, Steyermark 18542 (MBG).

Arkansas: rocky ledges, wooded slopes of Miller Mountain, near Farmington, Washington Co., May 9, 1924, Palmer 24763 (MBG,P); high rocky places, exact locality and date lacking, Pitcher s.n. (NY); moist shady woods, Cedar Glades Road, near Hot Springs, April 29, 1934, Scully 90 (MBG); common in woods, Eureka Springs, May 8, 1902, Bush 1526 (MBG); limestone ledges and talus, about $10 \mathrm{mi}$. south of Fayetteville, Washington Co., May 1, 1933, Woodson छ Hubricht s.n. (MBG); common along road to tower, summit of Rich Mt., Polk Co., April 28, 1935, Heinze s.n. (MBG); below cliffs, Eden's Bluff, Benton Co., May 1, 1931, Ruddick 264 (Ark).

Oklahoma: dense, moist woodland hillside, Muskogee Co., April 17, 1927, Little 590 (UO); Tahlequah, 1884, Bates s.n. (Ark). 
It is with great satisfaction that this species is dedicated to Mr. Ernest J. Palmer, long an assiduous student of the flora of southwestern Missouri and adjacent Arkansas. Mr. Palmer moreover has been of the greatest aid to the writers in their study of Tradescantia, lending his private herbarium for study, discussing difficult features of identity and relationships, and giving accurate directions for the revisitation of interesting localities in the field.

In $T$. Ernestiana many of the characteristics of $T$. subaspera, $T$. ozarkana, and T. virginiana find expression. The shape and dimensions of the petals and sepals, as also the indument of the latter, are very like those of $T$. virginiana. The foliage, on the other hand, has the proportions of that of $T$. ozarkana, but not the subsucculent texture of that species. The upper surface of the leaves is almost devoid of stomata as in T. ozarkana and $T$. subaspera. A distinctive feature of the foliage of $T$. Ernestiana is the very narrow basal and juvenile leaves, which are almost linear in shape. The bracts, on the other hand, are usually broader than the cauline leaves, giving the aspect of the foliage from base to bracts an inverse aspect seen in no other species in our range. Although it may be argued that the species may represent merely a well-marked variety of $T$. virginiana, which it imitates in its floral characters, it is distinct cytologically, being a diploid species, whereas all known plants of $T$. virginiana are tetraploid. An interpretation of hybridity appears quite unlikely.

Tradescantia Ernestiana and T. ozarkana evidently hybridize in the vicinity of Roaring River State Park, Barry Co., Missouri.

\section{Tradescantia virginiana Linnaeus}

(Plates II, fig. 2; III, fig. 2; IV, fig. 8; VI, fig. 5; VII, fig. 7)

Roots relatively slender, only slightly fleshy, not persistently pilose, or very inconspicuously and irregularly so; stems erect or ascending, straight, not flexuose, $0.5-3.5 \mathrm{dm}$. tall, glabrous, or rarely somewhat puberulent above; nodes $2-5$; internodes 3-20 cm. long; leaves membranaceous, dull green, not glaucous, the blade linear-lanceolate, long-acuminate, $13-35 \mathrm{~cm}$. long, $0.4-2.5 \mathrm{~cm}$. broad, glabrous, infrequently sparsely pilosulous at the sheath, stomata scattering upon the upper surface, less numerous than upon the lower, the sheath $0.4-3.0 \mathrm{~cm}$. long, 
$0.5-3.0 \mathrm{~cm}$. broad; cymes umbellate, few- to many-flowered, terminal, solitary, or very infrequently lateral also with long peduncles at the uppermost node toward the end of the season; bracts foliaceous, $10-32 \mathrm{~cm}$. long, $0.6-2.5 \mathrm{~cm}$. broad, widely spreading, and the tips commonly somewhat reflexed; pedicels $1.5-3.5 \mathrm{~cm}$. long, spreading and somewhat accrescent in fruit, eglandular-pilose; sepals ovate-elliptic, acute to acuminate, $0.9-1.6 \mathrm{~cm}$. long, rather delicately foliaceous, bright green, more or less turgid and inflated, uniformly eglandular-pubescent; petals broadly ovate, $1.2-1.8 \mathrm{~cm}$. long, various shades of blue to purple, infrequently rose or white; filaments abundantly pilose, connective broadly trapezoid; ovary ovoid, eglandular-pubescent, rarely glabrous; capsules obovoid-trigonal, $0.4-0.7 \mathrm{~cm}$. long; seeds roughly compressed-oblongoid, $0.2-0.3 \mathrm{~cm}$. long, the funicular scar linear, about as long as the seed.

Tradescantia virginiana Linnaeus, Sp. Pl. 288 (1753). - Britton, Man., 241 (1901). - Robinson \& Fernald in Gray, Man. ed. 7. 264 (1908). Britton \& Brown, Ill. Fl. ed. 2, 1: 461 (1913). - Brückner in Engler \& Prantl, Nat. Pflanzenfam. ed. 2, 15a: 166 (1930), in part.

Tradescantia virginica Linnaeus, Syst. ed. 10. 975 (1759). - Watson \& Coulter in Gray, Man. ed. 6, 539 (1889). - C. B. Clarke in DC. Monogr. 3: 290 (1881), in part.

Ephemerum congestum Moench, Meth. 238 (1794).

Tradescantia Speciosa Salisbury, Prodr. 216 (1796).

Tradescantia congesta [Moench] D. Don ms. ex [Penny in] Young, Hort. Epsom. 48 (1828), nomen. - Penny in Loudon, Hort. Brit. ed. 2, 601 (1832), nomen.; n. ed. 677 (1839); n. ed. 650 (1850).D. Don ms. ex Maund, Bot. Gard. 4: no. 363, t. (1831-32).

Tradescantia rupestris Rafinesque, Atl. Jour. 1: 150 (1832).

Tradescantia brevicaulis Rafinesque, loc. cit. (1832). - Britton, Man. 241 (1901). - Robinson \& Fernald in Gray, Man. ed. 7, 264 (1908). - Britton \& Brown, Ill. Fl. ed. 2, 1: 460 (1913). - Small, Fl. Southeast. U.S., 238 (1903).

Tradescantia Virginica L. var. alba Hooker ex Rafinesque, New Fl. 2: 84 (1836).

Tradescantia Virginica L. var. purpurea Rafinesque, loc. cit. (1836).

Tradescantia Virginica L. var. barbata Rafinesque, loc. cit. (1836).

Tradescantia Virginica L. var. ramosa Rafinesque, loc. cit. 85 (1836).

Tradescantia Virginica L. var. angustifolia Rafinesque, loc. cit. (1836).

Tradescantia ciliata Rafinesque, loc. cit. (1836).

Tradescantia pumila Rafinesque, loc. cit. 86 (1836).

Tradescantia discolor Rafinesque, loc. cit. 87 (1836), non l'Herit.

Tradescantia discolor Rafinesque, var. ramosa Rafinesque, loc. cit. (1836).

Tradescantia glabra C. B. Clarke in DC. Monog. 3:290 (1881), in synon.

Tradescantia albida Kunth ex C. B. Clarke loc. cit. (1881), in synon. 
Tradescantia Virginica L. var. villosa S. Watson in Proc. Amer. Acad. n.s. 18: 168 (1883). - Watson \& Coulter, in Gray, Man. ed. 6, 539 (1889).

Tradescantia Virginica L. forma albiflora Britton in Bull. Torrey Bot. Club, 17: 125 (1890).

Woods and thickets, spreading to meadows, fields, roadsides, and railroad right-of-ways, Connecticut to northern Georgia, westward to eastern and central Missouri. Frequently cultivated, and escaping to naturalize elsewhere.

MAP 5.

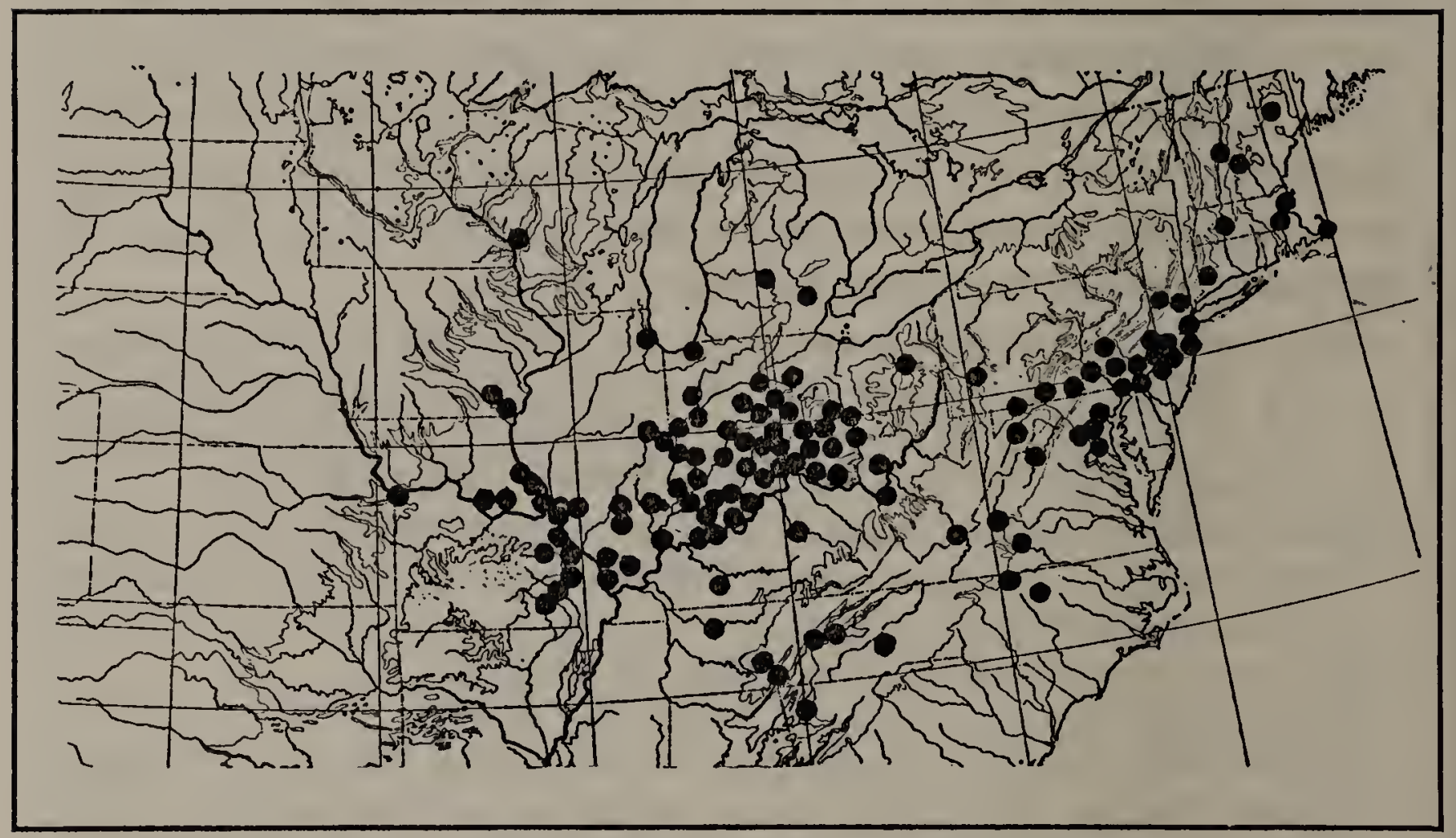

Map 5. Range of Tradescantia virginiana.

Maine: Norway village, Oxford Co., July 5, 1907, Chamberlain s.n. (NE).

New Hampshire: Danbury, Merrimack Co., July 11, 1933, Bullard s.n. (NE); Hanover, June 25, 1883, Hitchcock s.n. (UW).

Massachusetrs: grassy slope, wild and well established, Walpole, Norfolk Co., June 7, 1896, Williams s.n. (NE); waste lands, Back Bay Fens, Boston, Suffolk Co., Sept. 17, 1916, Collins 3674 (NE); spreading about abandoned house sites, Harwich, Barnstable Co., June 26, 1918, Fernald 16514 (NE); Sumner Avenue, roadside, Springfield, Hampden Co., June 17, 1914, Andrews s.n. (NE).

Connecticut: alluvial soil, probably introduced, but appearing as if perhaps native, Derby, New Haven Co., May 29, 1899, Harger s.n. (NE); abundant, and apparently native in meadows along Pomperaug River, Sou thbury, June 23, 1923, Weatherby 5177 (US); meadow along Pomperaug River, So. Britain, May 30, 1909, Blewitt s.n. (MBG); plentiful along bank of Housatonic River, probably introduced, Stratford, June 3, 1895, Eames s.n. (G,US); Fairfield, June 24, 1902, Eames s.n. (G). 
New York: near old cellar hole, Staten Island, June 9, 1928, Drushel 6565 (US).

New Jersey: moist, rocky wooded slope, Bald Pate Mt., facing Delaware River, Titusville, Mercer Co., May 31, 1924, Long 30393 (PBC); moist woods by roadside, River Ave., foot of Lake Carasaljo, Lakewood, Ocean Co., June 22, 1917, Long 16362 (PBC); left side of the Great Falls, Paterson, June 3, year uncertain, Hexamer \& Maier s.n. (NY); sandy field, $\mathrm{r} / 2 \mathrm{mi}$. n.e site of dwelling, Cookstown, Burlington Co., June 7, 1924, Long 30632 (PBC); dry woodlands, west of Hainesville, Sussex Co., June, 1922, Mackenzie s.n. (NY); roadside escape, Albion, Camden Co., June 7, 1924, Meredith s.n. (PBC); Swedesboro, June 8, 1892, Lippencott s.n. (PBC).

Pennsylvania: along R.R., York Furnace Station, Lancaster Co., May 14, 1899, MacElwee 208 (MBG,NY,PBC); Hellertown, June 7, 1849, Detwiller s.n. (PBC); cedar barrens, Chester Co., May 30, 1909, Pennell 1387 (PBC); alluvial banks of Crum Creek, Swarthmore, Delaware Co., June 11, 1908, Long s.n. (PBC); Wissahickon, e. side, high rocks above Thorpe Lane, Philadelphia Co., June 3, 1904, Van Pelt s.n. (PBC); wooded slope Swamp Creek, Zieglersville, Montgomery Co., June 10, 1923, Dreisbach 1461 (PBC); grassy roadside, Center Bridge, Bucks Co., May 29, 1926, Benner s.n. (PBC); a roadside escape about $7 / 8$ mile w. of Powder Valley P.O., Lehigh Co., June 11, 1916, Pretz 8147 (PBC); York, June, 1889, Miller s.n. (NY); Gettysburg, July 5, 1895, Mearns s.n. (US); Mercersburg, 1887, Green s.n. (G); Elwyn, June 4, 1891, Brinton s.n. (FM); south of Myerstown, Lebanon Co., May 23, 1890, Kaufman 170 (Mich).

Delaware: Centerville, June 2, 1873, Commons s.n. (NY); rich soil, Mt. Cuba, July 5, 1897, Commons s.n. (ANSP).

Maryland: Cumberland, May, 1894, Shriver s.n. (NY); open slopes along Susquehanna River, Bald Friar, Cecil Co., April 18, 1913, St. John छ Long 8053 (PBC); on rocks of old quarry, Glen Echo, May 8, 1904, Painter 582 (MBG); Baltimore, date lacking, Taylor s.n. (US); High Island. June 6, 1881, Sheldon s.n. (US); Marlboro, May 23, 1915, Hitchcock 12652 (US).

District of Columbia: Woodley Park, May 29, 1880, Ward s.n. (US); Chatauqua, May 22, 1896, Steele s.n. (US); Pinehurst, July 5, 1915, Steele s.n. (US).

Virginia: Natural Bridge, May 10, 1887, Kennedy s.n. (ANSP); among rocks at Great Falls of the Potomac, May 20, 1914, Holm s.n. (MBG); Mountain Lake, June 1, 1890, Brown Hogg Vail Timmerman Britton \& Britton s.n. (NY); Massanutten Mts., Page Co., May 13, 1900, Miller s.n. (US); Campbell Co., June 1, 1869, Curtiss s.n. (G); near Luray, May 3, 1903, Willis s.n. (US).

West Virginia: open woods, Huntington, May 18, 1928, Gilbert 101 (G); Moorefield, moist woods, May, year lacking, Gamble s.n. (WV).

North Carolina: damp banks, Black Mountain, June 21, 1920, Davis 1665 (MBG); Spray, date lacking, de Chalmot s.n. (US); alluvial soil, near Morgan's Creek, south of Carrboro, May 4, 1922, Smith s.n. (NC). 
Georgia: Calhoun, May 6, 1901, Boynton s.n. (MBG).

OHro: damp place, Hillsboro, Highland Co., June 1, 1916, Roads s.n. (OSU); Dayton, Montgomery Co.. 1895, Jaske s.n. (OSU); Greenville, Darke Co., May 14, 1895, collector unknown (OSU); London, Madison Co., 1892, Sharpe s.n. (OSU); Chillicothe, Ross Co., Bower s.n. (OSU); Wapokoneta, Auglaise Co., 1928, Kayser s.n. (OSU); Rio Grande, Gallia Co., 1892, Deckard s.n. (OSU); Green Co., May 10, 1902, Horlacher s.n. (OSU); Stark Co., 190-, Smith s.n. (OSU); Ft. Ancient, Warren Co., June 11, 1904, Horlacher s.n. (OSU); Loveland, Clermont Co., July 6, 1877, James s.n. (OSU); Blue Creek, Adams Co., May 10, 1930, Hicks s.n. (OSU); near Cincinnati, May 26, 1890, Lloyd s.n. (MBG); Columbus, 1835, Lapham s.n. (UW).

Kentucky: near Smith's Grove, Warren Co., June 17, 1889, Price s.n. (MBG); top of cliff, Shaker Ferry, date lacking, Peter s.n. (UK); common along railroad banks, High Bridge, April 30, 1907, Gilbert 980 (UK).

Tennessee: vicinity of Nashville, May 1886, Gattinger s.n. (US); hills near Tullahoma, May 9, 1898, Eggert s.n. (MBG,NY); dry hills near Normandy, May 9, 1898, Eggert s.n. (MBG); Walden's Ridge, Roane Co., April, 1893, Kearney s.n. (OSU); woods, Burlington, Knox Co., May 2, 1919, Ainslie s.n. (KSAC).

Michigan: along right of way, Lansing, June 11, 1917, Yuncker 197 (US); Ypsilanti, May 21, 1918, Walpole s.n. (Mich).

INDIANA: dry hill in open woods on east side of lakes in Jackson Tp., Wells Co., May 21, 1905, Deam s.n. (D,MBG); Terre Haute, May 10, 1890, Rutter s.n. (US); wooded bottoms, White River, Marion Co., May, 1904, Bartlett s.n. (G); infrequent in a moist white-oak-beech woods $3 \mathrm{mi}$. south of Yorktown, May 29, 1925, Deam 41292 (D); wooded white oak slope, 21/2 miles southeast of Farmer's Retreat, Dearborn Co., May 23, 1924, Deam 40334 (D); in the post oak flats on the south side of Half Moon Pond, about $10 \mathrm{mi}$. southwest of Mt. Vernon, Posey Co., May 25, 1926, Deam 42938 (D); clay bank of wooded bank of ravine near "knobs", Clark Co., May 11, 1910, Deam 5869 (D); in a black and white oak woods just south of Fountain, Fountain Co., May 9, 1919, Deam 27328 (D); common in large colonies in a white oak woods 8 mi. northeast of Portland, May 14, 1921, Deam 33860 (D); rare in a level sandy black oak woods on Margaret Trasker's farm about $21 / 2 \mathrm{mi}$. southeast of Union Mills, Laporte Co., May 29, 1927, Deam 44364 (D); in a black and white oak woods about $1 \mathrm{mi}$. north of Uniontown, Perry Co., May 7, 1929, Deam 46553 $(\mathrm{D}, \mathrm{MBG})$; in a hard white clay soil in a post oak-shingle oak flat in a woods along Little Pigeon Creek about $31 / 2 \mathrm{mi}$. northwest of Chrisney, Spencer Co., May 5, 1929, Deam 46540 (D,MBG); wooded slope of the bank of Tippecanoe River $5 \mathrm{mi}$. east of Brookston, June 8, 1924, Deam 40645 (D); also represented in the herbarium of Mr. Deam from Brown, Crawford, Daviess, Decatur, Dubois, Floyd, Franklin, Fayette, Grant, Greene, Harrison, Henry, Jay, Jackson, Jennings, Knox, Lawrence, Owen, Ripley, Scott, Shelby, Tippecanoe, Union, Washington, and Wells Counties. 
Wisconsin: near Fountain City, Buffalo Co., date lacking, Finkelnburg s.n. (CM).

Illinois: Iuka, May 28, 1904, Jensen s.n. (MBG); dry hills near Drivers, Jefferson Co., May 13, 1898, Eggert s.n. (MBG); rich hillside woods, Vienna, Johnson Co., April 28, 1919, Palmer 14972 (MBG); rich woods, Washington Heights, Chicago, June 11, 1880, Hill s.n. (NY); hills near French Village, St. Clair Co., May 14, 1878, Eggert s.n. (MBG); Carbondale, May 31, 1885, Wislizenus 422 (MBG); "Bird Haven," Richland Co., May 8, 1910, Ridgway s.n. (US); moist sandstone bluffs, Cobden, Union Co., May 23, 1902, Earle 742 (NY); bluffs south of Muncie, Vermillion Co., May 11, 1917, Gates 1465 (US); clay bank along Salt Fork, e. of Urbana, Champaign Co., May 18, 1907, Gates 1507.1 (FM).

IowA: damp woods, Sugar Creek, Lee Co., May 19, 1914, Davis s.n. (MBG); roadside, Stockport, May, 1925, Graves 2139 (MBG).

Missourr: along moist shaded ledges, sandstone bluffs of Little St. Francis River, Mine La Motte, Madison Co., May 22, 1926, Palmer 30291 (MBG); rocky hills near De Soto, Jefferson Co., May 11, 1896, Eggert s.n. (MBG,NY); woods, Grandin, May 6, 1905, Bush 2707 (FM,MBG,NY); sunny granitic hillside woods, east side of Jonca Creek, Ste. Genevieve Co., May 30, 1933, Woodson E Steyermark s.n. (MBG); Potosi, Washington Co., June 3, 1892, Dewart 88 (MBG); Pleasant Grove, common in rich woods, May 21, 1900, Bush 355 (MBG); barrens, Dodson, May 10, 1896, Mackenzie s.n. (NY); damp bluffs, Foristell, St. Charles Co., May 25, 1917, Davis 7360 (MBG); Whiteside, Lincoln Co., damp roadsides, May 19, 1919, Davis 4403 (MBG); near Eolia, Pike Co., May 29, 1916, Davis 1240 (MBG); wooded hillsides, Algonquin Sta., Webster Groves, St. Louis Co., May 10, 1933, Woodson 3300 (MBG); McBaine, Boone Co., May 4, 1902, Favor s.n. (Mo); dry upper slopes of St. Peter sandstone bluffs, along Mill Branch, northeast of Big Spring, Montgomery Co., Oct. 3, 1934, Steyermark 15778 (MBG); 1/2 mi. east of Greenville, Wayne Co., Apr. 26, 1935, Hubricht s.n. (MBG).

Perhaps the most characteristic feature of $T$. virginiana $\mathrm{L}$. is the turgid or inflated, delicately foliaceous, eglandular-pubescent calyx, a character only approached in $T$. Ernestiana among the other American species of the genus. As the synonymy indicates, the species is a variable one.

One of the most perplexing situations encountered in this study surrounds the identity of $T$. brevicaulis Rafinesque, a name which has been accorded wide recognition since its publication in 1832 . Rafinesque's description of the species is characteristically inadequate: "Stem simple very short, flexuose, leaves much longer, narrow, nearly flat, carinate striate, base vaginate tubular membranaceous ciliate: umbel pauciflore, bracts equal to leaves, peduncles and calix very pilose. . . Vernal fl. blue small, a small sp. stem only 3 to 6 inches. Illinois and Kentucky [Atl. Jour. 1: 
150. 1832]." In the absence of historical specimens, the identity of this species may be decided by ascribing it to one of the three species native to the region cited: $T$. subaspera, $T$. canaliculata, and $T$. virginiana. Of these three, the former can hardly include plants similar to the meagre description of $T$. brevicaulis, since it is the most massive of the American representation of the genus; the leaves are also notably broad and the stem much branched. Moreover, T. canaliculata differs from Rafinesque's $T$. brevicaulis, as in the former the whole inflorescence is glabrous, or merely the tips of the sepals inconspicuously barbate, whereas in the latter the "peduncles and calix" are described as "very pilose."

There is nothing in the description of $T$. brevicaulis which is not conformable with $T$. virginiana. One has only to examine a fair number of representative specimens, in either the field or the herbarium, to find that the size of individual plants of the latter species is extremely variable, ranging from $0.5-3.5 \mathrm{dm}$. in height in single colonies of considerable size. We are forced to believe, therefore, that $T$.brevicaulis Rafinesque can be applied only to unusually small specimens of $T$. virginiana. Moreover, the manifest variability of the specimens, particularly in dry or otherwise unfavorable situations, appears to admit not even of varietal or formal recognition. It is possible to produce such slender, shortstemmed plants experimentally by decapitating pot grown specimens and forcing them to send up a second shoot. The situation has been further complicated by the extension of the use of $T$. brevicaulis Rafinesque to short-stemmed plants west of the Mississippi River, concealing in that way the true nature of two distinct species which are described as new in subsequent paragraphs of this study. Petal color in the American tradescantias is so variable and complex that it has been considered more practical to ignore forms and varieties based upon that factor for the present.

Due to the long cultivation of this species, its exact natural range can only be surmised in some instances. This is particularly true of the citations of specimens from the New England states, with the possible exception in part of those from Connecticut. The specimens from New England have not always been found where they might obviously have escaped from cultivation, but they very frequently show biological evidence of previous cultivation, such as more or less marked traces of hybrid 
ancestry. Hybridization among cultivated species of Tradescantia is usually easy of observation: in fact most cultivated plants, unless of relatively recent transplanting from their spontaneous habitat, show the poor definition of taxonomic characters commonly associated with hybridization. Hence, it was not immediately decided to record the occurrence of specimens which might well have escaped from cultivation or have spread as ruderals. Upon consideration, however, the value of such records to a dynamic study of our flora must be admitted. The flora of today surely differs from that of five hundred or more years ago, due largely to the influence of an increasingly complicated civilization; may it not be of interest to record in detail the ruderals and escapes of to-day as a prophesy of the flora of the not distant future?

Considerable interest is attached to the single collection of this species from the "driftless" area of western Wisconsin. According to Dr. N. C. Fassett, this record is probably that of an escape. It is very desirable that this extension of the known distribution of $T$. virginiana be verified.

\section{Tradescantia hirsutiflora Bush}

(Plates IV, fig. 3; VI, fig. 7)

Roots relatively long, somewhat fleshy, inconspicuously and irregularly pilose to glabrate; stems erect or ascending, straight, or very slightly flexuose, $1.2-4.9 \mathrm{~cm}$. long, more or less spreadingpilose, or hirsute, infrequently glabrate; nodes $2-5$; internodes 1-21 cm. long; leaves firmly membranaceous, deep green to somewhat subglaucous, the blade linear-lanceolate, long-acuminate, $14-32 \mathrm{~cm}$. long, $0.6-2.0 \mathrm{~cm}$. broad, scatteringly pilose, particularly at the sheaf, infrequently glabrate or glabrous, stomata somewhat more numerous upon the lower surface than upon the upper, the sheath rather turgid and inflated, $0.6-2.0 \mathrm{~cm}$. long, $0.7-2.0 \mathrm{~cm}$. broad; cymes umbellate, few- to many-flowered, terminal, solitary, or accompanied by lateral, pedunculate inflorescences at the upper nodes; bracts foliaceous, widely spreading or divaricate, $4-16 \mathrm{~cm}$. long, $0.5-1.4 \mathrm{~cm}$. broad, scatteringly pilose to glabrate or glabrous; pedicels $1.5-3.0 \mathrm{~cm}$. long, pilose, or very rarely glabrate, more or less reflexed and accrescent after maturity; sepals broadly elliptic, acute to acuminate, 0.7-1.3 $\mathrm{cm}$. long, dull green, not infrequently somewhat suffused or edged with rose, not inflated, pubescent with eglandular, or 
glandular and eglandular hairs interspersed; petals broadly ovate, $1.2-1.8 \mathrm{~cm}$. long, bright blue, rarely pink; filaments abundantly pilose, connective broadly trapezoid; ovary ovoid, pubescent with eglandular, or glandular and eglandular hairs interspersed, rarely glabrate; capsules obovoid-oblongoid, 0.5$0.7 \mathrm{~cm}$. long; seeds roughly compressed-oblongoid, $0.2-0.3 \mathrm{~cm}$. long, the funicular scar linear, about as long as the seed.

Tradescantia hirsutiflora Bush in Trans. Acad. Sci. St. Louis, 14: 184 (1904). - Rydberg, Fl. Prairies \& Plains, 199 (1932).

Tradescantia australis Bush, loc. cit. 185 (1904).

Tradescantia eglandulosa Bush, loc. cit. 191 (1904).

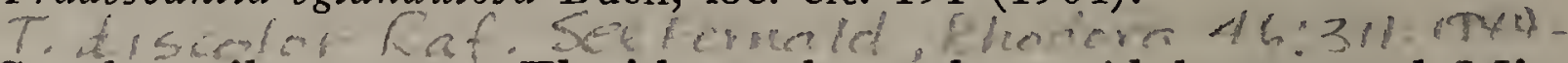

Sandy soil, western Florida and southern Alabama and Mississippi to Louisiana and Texas and adjacent Arkansas; also collected in eastern Oklahoma.

MAP 6.

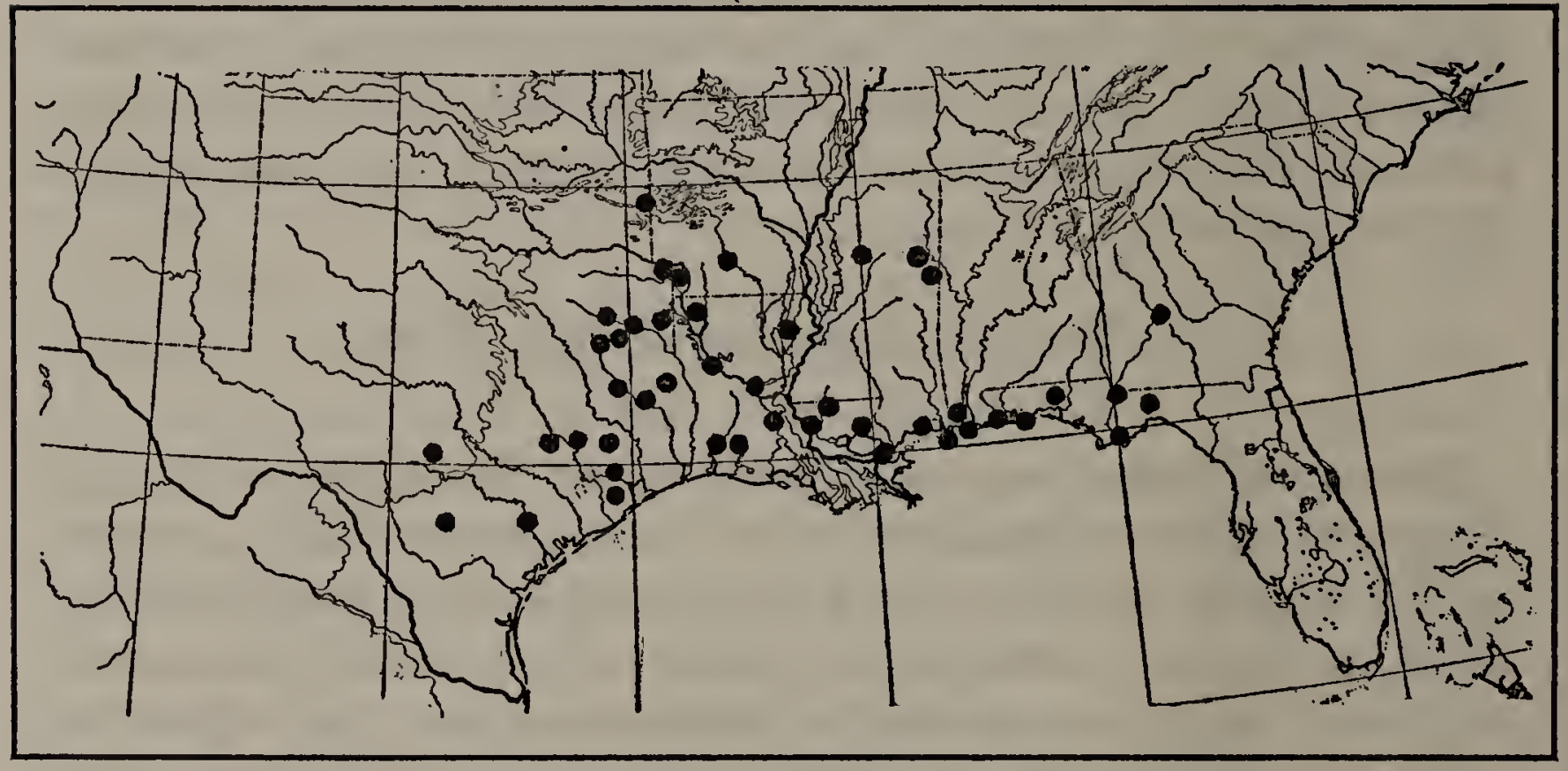

Map 6. Range of Tradescantia hirsutiflora.

Georgia: 8 miles south of Sylvester, April 21, 1933, Coker Totten छ Harbison s.n. (NC).

FlORIDA: one mile south of River Junction, limestone swamp, April 20, 1933, Coker Totten छ Harbison s.n. (NC); Pensacola, April 14, 1926, Howell 1149 (US); Santa Rosa Island, April 18, 1926, Howell 1153 (US); dry open barrens, drifting sands, near Apalachicola, March 12, 1898, Mohr s.n. (US); near Tallahasee, date lacking, Berg s.n. (NY); in dry sandy woods, East Point, Franklin Co., May 5, 1930, Moldenke 1135a (MBG,NY); sandy woods near De Funiak Springs, April 6, 1925, Small E Wherry 11700 (NY); "East Florida," 1874, Palmer 574 (MBG,US).

Alabama: Fort Morgan, April 26, 1901, Tracy 7488 (NY,US); Montgomery, April, 1868, Mohr s.n. (US); roadsides, Spring Hill, 1919, Graves 1940 (MBG). 
Mississippi: Biloxi, April 1, 1898, Tracy 5123 (US); Petit Bois Island, May 8, 1898, Tracy 5125 (NY,US); Ocean Springs, May 13, 1895, Skehan s.n. (MBG,US); Coopolis, April 24, 1898, Tracy 5126 (MBG,NY,US); Macon, June 1, 1897, Tracy 3219 (NY); in moist soil, North Carrollton, April 21, 1899, Clute 8 (NY); Flatwoods sec. about 7 miles west of Starkville, May 26, 1921, Tims s.n. (UW).

Louisiana: vicinity of Covington, May 14, 1920, Arséne 12173 (US); Opelousas, June, 1840, Carpenter s.n. (US); in low places around Lake Charles City, April 24, 1884, Langlois 362 (US); low pine woods, rare, vicinity of Alexandria, May 31, 1899, Ball 525 (MBG); open hillsides, Natchitoches, April 16, 1915, Palmer 7249 (MBG); prairies, Welsh, Jeff Davis Parish, May 17, 1915, Palmer 7657 a (MBG); ditches, New Orleans, Oct., 1899, Cocks s.n. (TU); R.R. clearings, Shreveport, Apr. 15, 1910, Cocks s.n. (TU); Harrisonburg, Apr. 26, 1913, Meeker s.n. (LSU); railroad, new campus, Baton Rouge, East Baton Rouge Parish, Apr. 25, 1933, Brown 3972 (LSU); cut-over pine woods, near Pine Grove, St. Helena Parish, Apr. 24, 1934, Brown 5203 (LSU); Acadia Parish, date lacking, Dormon 5 (MBG).

Texas: San Augustine, date lacking, Crocket s.n. (US); Cuero, March 22, 1907, Howell 330 (US); common in sand, Mineola, April 24, 1901, Reverchon 2479 (MBG,NY); low rich woods, Pine Island, May 7, 1903, Reverchon 4051 (MBG); Grand Saline, Van Zandt Co., April, 1901, Rererchon 2480 (MBG, TYPE); Gillespie Co., date lacking, Jermy s.n. (MBG); sandy banks, Marshall, Harrison Co., April 19, 1914, Palmer 5317 (MBG); near Longview, Gregg Co., April 19, 1899, Eggert s.n. (MBG); dry prairies near Polk, Bowie Co., June 13, 1898, Eggert s.n. (MBG); sandy soil, Navasota, April, 1903, Harbison s.n. (MBG); Big Sandy, Upshur Co., common in sands, May 28, 1901, Reverchon 2481 (MBG); sandy open woods, Grapeland, Houston Co., May 28, 1917, Palmer 12065 (G,MBG,NY,US); prairie, Alvin, March 22, 1918, Young 33 (T); Caldwell, Spr.-Sum., 1931, McBryde s.n. (T); along railroad, Athens, April 9, 1916, Young s.n. (T); sandy oak woods, Gonzalez, May 6, 1931, Tharp s.n. (T); sandy loam, Willis, April 24, year lacking, Warner s.n. (MBG); Swan, June 3, 1903, Reverchon s.n. (MBG); low rich woods, Maderez, 1903, Reverchon 4052 (MBG); Houston, April 16, 1872, Hall s.n. (FM,MBG); hills, 10 mi. n. of San Antonio, March 28, 1926, Bogusch s.n. (O).

Arkansas: sandy open woods along small creek, near Texarkana, Miller Co., April 16, 1926, Palmer 29671 (MBG); rich woods, Miller Co., April 22, 1905, Bush 2391 (MBG); Camden, May 11-17, 1850, Fendler s.n. (G,MBG).

Oklahoma: rocky hillsides, Page, Leflore Co., May 2, 1933, Woodson छ? Hubricht s.n. (MBG); Grassy Creek valley, near Page, Leflore Co., April 20, 1913, Stevens 1381 (G,MBG,US).

This species is probably the most difficult and unsatisfactorily understood of the American representation of the genus. In habit it closely simulates the more northern and eastern $T$. vir- 
giniana, but differs from it quite evidently in the predominantly pubescent stem, and in the coarser, duller calyx, which is not turgid and inflated as in that species. $T$. hirsutiflora offers an interesting, if perplexing parallel to the southern Appalachian $T$. subaspera in the variability of the indument of the sepals and pedicels, which may be either wholly eglandular-pubescent, or with eglandular and glandular hairs interspersed.

A possible alternative to the splitting of the species as recognized here into three or more exceedingly indistinct species, is the subdivision into varieties, based in part on the variable character of the indument, and partly on other evasive characters as the general aspect of the plant, amount of branching, etc. Such a solution of the problem upon trial by the authors of this study has seemed scarcely more satisfactory than the recognition of an indivisible, polymorphic species, although additional study, particularly in the field, may eventually prove otherwise. As considered in the present instance, the species is found to have a fairly natural distribution. Finer "splitting" has been found to have a less satisfactory result from the same consideration.

\section{Tradescantia Tharpii, sp. nov.}

(Plates IV, fig. 9; IX)

Planta subacaulis cum $T$. brevicauli Rafinesque olim confusa; radicibus partim conspicue carnosis partim tenuissimis fibrosis inconspicuis glabratis; caulibus erectis strictis longe pilosis villosissimisve primum in flore $0.2-0.7 \mathrm{dm}$. longis, vel planta frequenter ut videtur subacaulis, deinde in fructu saepe ad 2 $\mathrm{dm}$. attingentibus; nodis $1-2$; internodiis $1-9 \mathrm{~cm}$. longis; foliis firme membranaceis viridibus haud glaucescentibus, lamina lineari-lanceolata longe acuminata $14-30 \mathrm{~cm}$. longa $0.9-2.5 \mathrm{~cm}$. patula lata laxe irregulariterque pilosa villosissimave, vagina $0.5-1.5 \mathrm{~cm}$. longa $0.3-3.1 \mathrm{~cm}$. lata ad basim caulis plerumque imbricata; cymis umbellatis multifloris terminalibus solitariis; bracteis foliaceis $4-26 \mathrm{~cm}$. longis $0.9-2.5 \mathrm{~cm}$. latis patulis; pedicellis gracilissimis $4-6 \mathrm{~cm}$. longis laxe pilosis plus minusve purpureo-roseis raro dilute viridibus post maturitatem reflexis paulo accrescentibus; sepalis late ellipticis acute acuminatis $1.2-1.6 \mathrm{~cm}$. longis uniformiter eglandulo-pilosis aliquanto petalaceis purpureo-roseis raro dilute viridibus haud inflatis; petalis late ovatis $1.8-2.2 \mathrm{~cm}$. longis saturate roseis vel purpureis non raro caeruleis; filamentis pilosis, connectivo late trapezoideo; 
ovario ovoideo uniformiter eglandulo-pubescente raro glabro; capsulis obovoideo-trigonalibus $0.5-0.7 \mathrm{~cm}$. longis; seminibus plane oblongoideis $0.2-0.3 \mathrm{~cm}$. longis funiculo lineari semen paene aequante.

Roots in part relatively short and fleshy, in part inconspicuous, slender, and fibrous, glabrate; stems erect, straight, rarely branching, in flower $0.2-0.7 \mathrm{dm}$. and frequently plant long apparently acaulescent, later, in fruit, frequently attaining a height as much as $2 \mathrm{dm}$., shaggy-pilose to villous; nodes $1-2$; internodes $1-9 \mathrm{~cm}$. long; leaves firmly membranaceous, green, not glaucous, the margins frequently hyaline or edged with rose, the blade linearlanceolate, long-acuminate, $14-30 \mathrm{~cm}$. long, $0.9-2.5 \mathrm{~cm}$. broad, laxly and irregularly pilose or villous, widely spreading, the sheath $0.5-1.5 \mathrm{~cm}$. long, $0.3-3.1 \mathrm{~cm}$. broad, usually imbricated at the base of the stem; cymes umbellate, multiflorous, terminal, solitary; bracts foliaceous, $4-26 \mathrm{~cm}$. long, $0.9-2.5 \mathrm{~cm}$. broad, widely spreading; pedicels very slender, $4-6 \mathrm{~cm}$. long, laxly pilose, more or less purple- or rose-colored, rarely pale green, after flowering reflexed and somewhat accrescent; sepals broadly elliptic, acute to acuminate, $1.2-1.6 \mathrm{~cm}$. long, uniformly eglandular-pilose, somewhat petalaceous, purple- or rose-colored, rarely pale green, not inflated; petals broadly ovate, $1.8-2.2 \mathrm{~cm}$. long, deep rose or purple, not infrequently blue; filaments abundantly pilose, connective broadly trapezoid; ovary ovoid, uniformly eglandular-pubescent, rarely glabrous; capsules obovoid-trigonal, $0.5-0.7 \mathrm{~cm}$. long; seeds roughly compressed-oblongoid, 0.2 $0.3 \mathrm{~cm}$. long, the funicular scar linear, about as long as the seed.

Tradescantia brevicaulis Rafinesque according to Bush, Trans. Acad. Sci. St. Louis, 14: 184 (1904), as to specimens cited, in part, not Rafinesque.

Rocky prairies, extreme southwestern Missouri and adjacent Kansas; northeastern Texas, eastern Oklahoma. MAP 7.

Missouri: common in prairies, Webb City, May 12, 1902, Bush 1608 (MBG); rocky prairies along Mo. Pac. R.R. between Webb City and Joplin, Jasper Co., April 30, 1933, Woodson E Hubricht s.n. (MBG, TYPE, G,FM,NY,US,ANSP); Willard, Green Co., April 25, 1897, Blankinship s.n. (G); Springfield, Greene Co., May 15, 1905, Standley s.n. (US); Lawrence Co., May 20, 1897, Flint s.n. (NY).

Kansas: Cowley Co., April, 1898, White s.n. (MBG); hills, Lindborg, May, 1887, Bodin s.n. (UM); Douglas Co., May, year lacking, Snow 2997 (K); Cloud Co., 1930, Fraser 58 (KSAC); Clay Co., 1895, Lechner 
s.n. (KSAC); wet springy place, Ellsworth Co., May 9, 1924, Ikenberry s.n. (KSAC); common on dry stony hills, southwest of Brookville, April 25, 1930, Hancin 189 (KSAC); NW of Linn, Washington Co., May 26, 1933, Dodd 32 (KSAC); Ottawa Co., May, 1887, Painter s.n. (KSAC).

Oklahoma: rocky slopes of Rich Mt., Leflore Co., April, 1934, Heinze s.n. (MBG); Arbuckle Mts., Murray Co., April 13, 1929, Gould s.n. (UO); bluff opposite springs, Platt National Park, Sulfur, April 27, 1935, G. M. Merrill 210 (G).

Texas: Fort Worth, April 1, 1902, Reverchon 2771 (MBG); Dallas, common in woods, April 24, 1900, Bush 578 (MBG,NY,US); sands, Dallas, April, 1880, Reverchon 4049 (G,MBG,US); rocky hillsides, Polytechnic, April 9, 1913, Ruth 265 (FM,MBG,T US); Jamestown, Tarrant Co., April 9, 1915, Ruth 265bis (G,US); Erath Co., March 10, 1921, Gough s.n. (T).

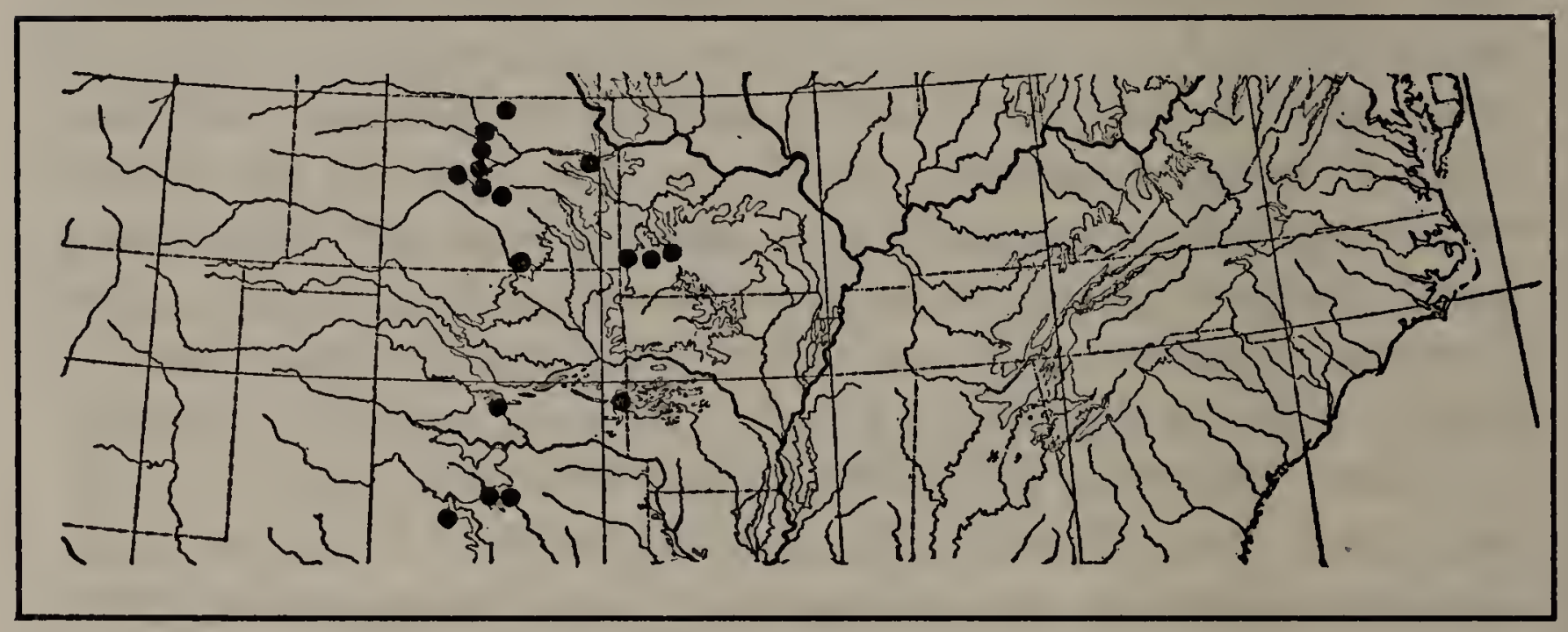

Map 7. Range of Tradescantia Tharpir.

It is easy to see how the preceeding plants were mistaken for $T$. brevicaulis Rafinesque in consideration of the ambiguity which surrounds the original description of that species. Our plants are among the most striking of the American tradescantias, not only because of the large number of vividly colored flowers produced at one time, but because of the florid pedicels and sepals, which add color to the plants even after the petals have dissolved into water after midday. The nearest relative of $T$. Tharpii appears to be another new species limited to a small district in southeastern Missouri, which will be described and discussed in a subsequent paragraph.

Tradescantia Tharpii is named in honor of Prof. B. C. Tharp, of the University of Texas, a keen student of the flora of his native state, who has been of the greatest aid in the pursuance of this study. 


\section{Tradescantia gigantea Rose}

(Plates IV, fig. 4; VI, fig. 6)

Roots relatively thick and fleshy, inconspicuously and irregularly pilose to glabrate; stems erect or ascending, straight, not flexuose, branching rather infrequently, 3-6 dm. tall, densely and minutely eglandular-puberulent above, glabrate below; nodes 3-5; internodes 4-16 cm. long; leaves firmly membranaceous, glaucous, the blade linear-lanceolate, long-acuminate, 10-35 $\mathrm{cm}$. long, $0.5-2.5 \mathrm{~cm}$. broad, glabrous, or the uppermost not infrequently densely and minutely velutinous and pouched as in the bracts, stomata about equally distributed on the upper and lower surfaces, the sheath rather turgid and inflated, $0.5-2.5 \mathrm{~cm}$. long, $1.2-3.0 \mathrm{~cm}$. broad; cymes umbellate, few- to many-flowered, terminal, solitary, or axillary at the upper nodes; bracts conspicuously saccate, their blades greatly reduced, more or less foliaceous, 3-10 cm. long, $0.9-1.9 \mathrm{~cm}$. broad, minutely and densely velutinous, sharply reflexed or divaricate; pedicels $1.2-2.5 \mathrm{~cm}$. long, densely and minutely eglandular-velutinous, more or less reflexed and accrescent in fruit; sepals broadly elliptic, acute, $0.6-1.1 \mathrm{~cm}$. long, densely and minutely eglandular-velutinous as in the bracts and pedicels; petals broadly obovate, rounded to broadly obtuse, $1.5-1.8 \mathrm{~cm}$. long, bright magenta-pink to blue; filaments abundantly pilose, connective broadly trapezoid, ovary ovoid, uniformly and minutely eglandular-velutinous as in the sepals; capsules $0.6-0.7 \mathrm{~cm}$. long; seeds roughly compressed-oblongoid, $0.2-0.3 \mathrm{~cm}$. long, the funicular scar linear, about as long as the seed.

Tradescantia gigantea Rose in Contrib. U.S. Nat. Herb. 5: 205 (1899). Bush in Trans. Acad. Sci. St. Louis, 14: 190 (1904). - Small, Fl. Southeast. U.S. 239 (1903).

Limited to east-central Texas.

MAP 8.

Texas: New Braunfels, April 14, 1897, Locke s.n. (NY,US, TYPE); Lake Austin, April 3, 1926, Bogusch 547 (US); Onion Creek, May, 1923, Tharp 2187 (T,US); Shovel Mt., Burnet Co., May 22, 1897, Schaupp s.n. (US); Gillespie Co., date lacking, Jermy s.n. (MBG); shaded limestone bluffs, San Saba, San Saba Co., May 4, 1917, Palmer 11792 (MBG,NY); University Campus, Austin, date lacking, Birge 3031 (T); Enchanted Rock, April 25, 1931, Tharp s.n. (T); dry pastures, Round Mt., Blanco Co., Mar.-Apr., 1896, Schaupp 19 (FM); rocky ground, New Braunfels, date lacking, Mackensen 149 (FM).

Tradescantia gigantea is such a well-marked and stable species that one might be inclined to believe its purity were maintained 
by genetic or cytological incompatibility with other neighboring species. That such is not the case, however, has been found by successful hybridization with $T$. canaliculata Rafinesque. This species differs from all other known tradescantias of the United States in its broad, obovate petals, as well as in the peculiarly saccate, velutinous bracts. The first leaves to develop in the spring are relatively broad, forming a cluster near the ground which might be mistaken for a plant of $T$. Tharpii. As the time for blooming approaches, the stems elongate, bearing narrower, relatively distant foliage.

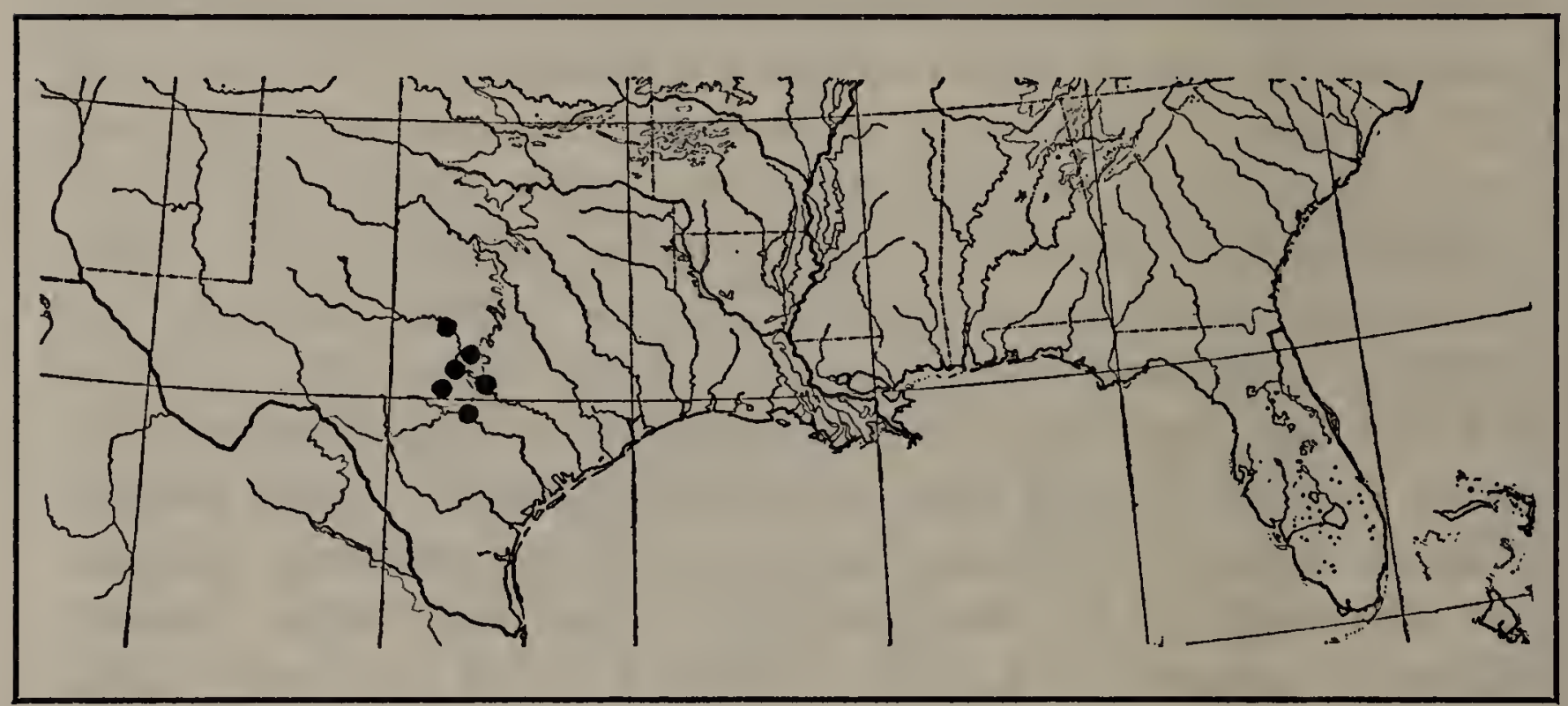

Map 8. Range of Tradescantia gigantea.

9. Tradescantia canaliculata Rafinesque

(Plates II, fig. 3; III, figs. 4, 5; IV, fig. 7; VI, fig. 4; VII, fig. 6)

Roots relatively slender, somewhat fleshy, very inconspicuously and irregularly pilose to glabrate; stems erect or ascending, straight, or slightly flexuose, $1.7-6.5 \mathrm{~cm}$. tall, glabrous, glaucous and subsucculent; nodes 3-8; internodes $1.5-18.0 \mathrm{~cm}$. long; leaves firmly membranaceous, glaucous, the blade linear-lanceolate, long-acuminate, $8-45 \mathrm{~cm}$. long, $0.5-4.5 \mathrm{~cm}$. broad, glabrous, or infrequently more or less pilose at the sheath, particularly the lower, stomata about equally distributed on the lower and upper surfaces, the sheath rather turgid and inflated, $0.5-4.0 \mathrm{~cm}$. long, $0.5-4.5 \mathrm{~cm}$. broad; cymes umbellate, few- to many-flowered, terminal, solitary, frequently accompanied at the upper nodes by lateral pedunculate inflorescences; bracts foliaceous, glaucous, glabrous, or very inconspicuously and minutely barbate at the tips, 4-25 cm. long, 0.4-2.2 cm. broad, sharply reflexed or

T. ohkisbis Rafo is comect mame- See Fornald,

Rhodora $46: 310-3111944$. 
divaricate; pedicels $0.7-2.5 \mathrm{~cm}$. long, glabrous, more or less reflexed and somewhat accrescent in fruit; sepals elliptic, acute to acuminate, $0.5-1.5 \mathrm{~cm}$. long, glaucous, infrequently somewhat suffused with rose or purple, glabrous, or more or less eglandularbarbate at the tips; petals broadly ovate, $0.8-2.0 \mathrm{~cm}$. long, blue to rose, magenta, or rarely white; filaments abundantly pilose, connective broadly trapezoid; ovary ovoid, glabrous, or with a tuft of weak, eglandular hairs at the base of the style; capsules obovoid-trigonal, $0.4-0.6 \mathrm{~cm}$. long; seeds roughly compressedoblongoid, $0.2-0.3 \mathrm{~cm}$. long, the funicular scar linear, about as long as the seed.

Tradescantia canaliculata Rafinesque, Atl. Jour. 1: 150 (1832).

Tradescantia divaricata Rafinesque, loc. cit. 148 (1832), non Vahl.

Tradescantia Ohioensis Rafinesque, New Fl. 2: 84 (1836).

Tradescantia barbata Rafinesque, loc. cit. 85 (1836).

Tradescantia laevigata Rafinesque, loc. cit. (1836).

Tradescantia laevigata Rafinesque, var. incarnata Rafinesque, loc. cit. (1836).

Tradescantia barbata Rafinesque var. pumila Rafinesque loc. cit. (1836).

Tradescantia barbata Rafinesque var. trachiloma Rafinesque, loc. cit. 86 (1836).

Tradescantia reflexa Rafinesque, loc cit. 87 (1836). - Small in Bull.

Torrey Bot. Club, 24: 232 (1897). - Bush in Trans. Acad. Sci. St.

Louis, 14: 186 (1904). - Britton, Man. 242 (1901). - Britton \& Brown, Ill. Fl. ed. 2. 1: 461 (1913). - Small, Fl. Southeast. U.S. 239 (1903). - Robinson \& Fernald in Gray, Man. ed. 7, 264 (1908).

Tradescantia reflexa Rafinesque var. drepisia Rafinesque, loc. cit. 88 (1836).

Tradescantia riparia Rafinesque, loc. cit. (1836).

Tradescantia caricifolia Hooker in Bot. Mag. n.s. 11: 3546 (1837).

Tradescantia Lyonii Schlechtendal in Linnaea, 25: 186 (1852).

Tradescantia trachyloma Rafinesque, ex C. B. Clarke in DC. Monogr. 3: 290 (1881) erron. in synon.

Tradescantia foliosa Small in Bull. Torrey Bot. Club, 24: 234 (1897); Fl. Southeast. U.S. 240 (1903).

Tradescantia incarnata Small in Bull. Torrey Bot. Club, 24: 239 (1897); Fl. Southeast. U.S. 239 (1903).

Tradescantia reflexa Rafinesque forma albiflora Slavin \& Nieuwland in Am. Midl. Nat. 11: 600 (1929).

Tradescantia reflexa Rafinesque forma Lesteri Standley in Rhodora, 32: 32 (1930).

Tradescantia reflexa Rafinesque forma Mariae Standley, loc. cit. (1930).

Meadows and thickets, less frequently in woods, commonly spreading to roadsides and railroad right-of-ways, southern New 
England to Florida, and westward to Minnesota and Texas; frequently cultivated in the United States, and escaping to naturalize. Our most common and wide-spread species. MAP 9.

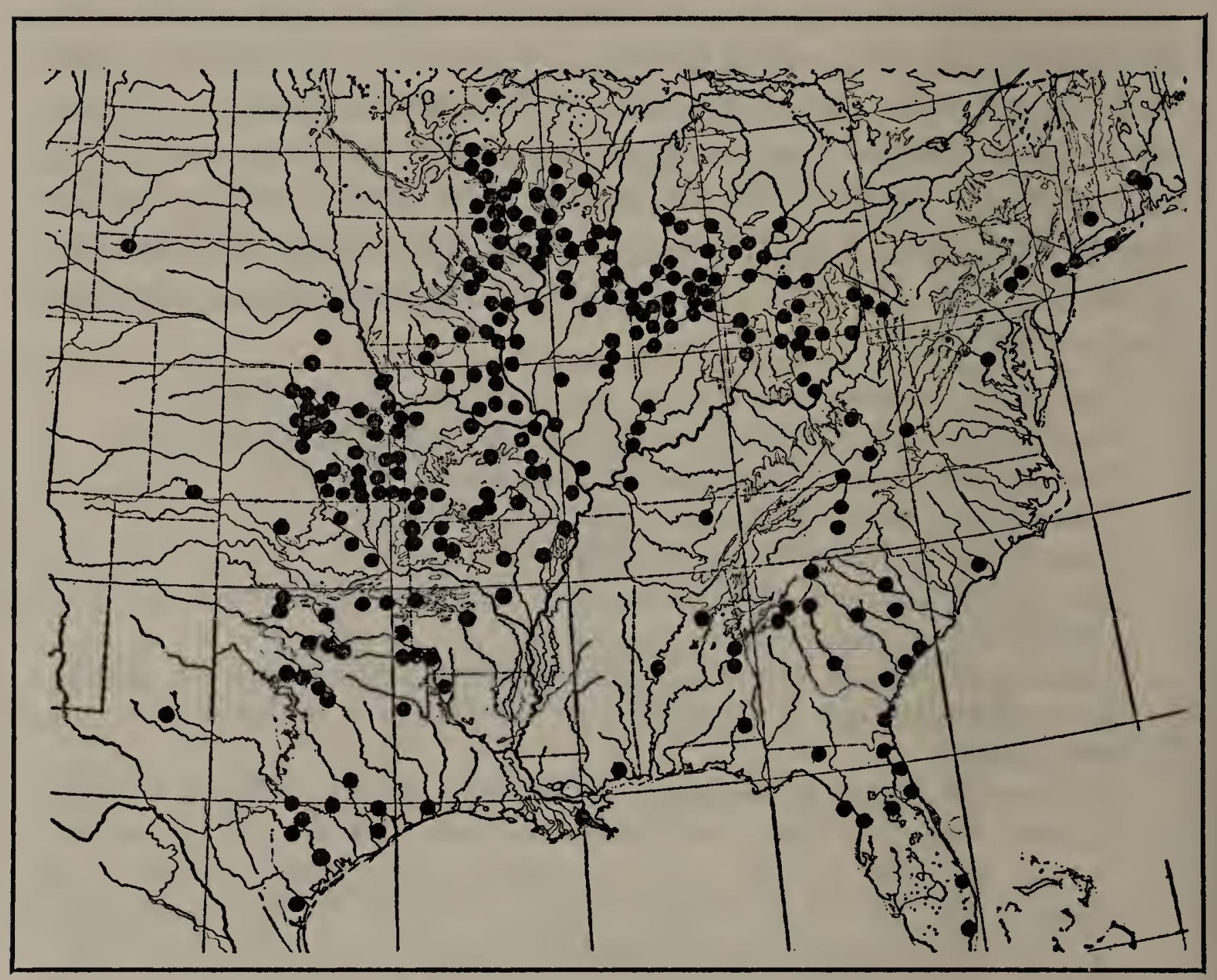

Map 9. Range of Tradescantia canaliculata.

MassachusetTs: growing by the side of the B. \& A. RR., $1 / 2$ mile from any house, Ashland, Middlesex Co., May 30, 1887, Collins s.n. (NE); gravelly R.R. bank near station, Walpole, Norfolk Co., June 7, 1896, Rich s.n. (NE).

Connecticut: waste ground, Naugatuck, New Haven Co., July 25, 1912, Blewitt 1350 (NE).

New York: Shinnecock Indian Reservation, Suffolk Co., June 5, 1931, Lassiter s.n. (NYSM); E. of Aqueduct, Long Island, Sept. 21, 1903, Bicknell 246 (NYSM).

New Jersey: Colonia, Aug. 16, 1917, Lighthipe s.n. (T).

Pennsylvania: along west embankment of L.V.RR. track just south of Lehigh Gap Sta., July 12, 1914, Pretz 6910 (PBC); wet meadows, Beaver Co., 1899, Mansfield s.n. (CM); Sinking Spring, June 21, 1878, Oberly 2996 (CM); Sample Sta., Allegheny Co., June 12, 1917, Patterson s.n. (CM).

District of Columbia: north side of Kalorama, toward Rock Creek, May 16, 1919, Steele 43 (US). 
Virginia: bluff on an open bank, Natural Bridge, May 30, 1910, Bartram s.n. (ANSP); south slope of White Rock Mountain, Smyth Co., June 21, 1892, Small s.n. (MBG,NY); East River Mt., Bland Co., Sept. 1, 1931, Core s.n. (NY); near Carter's Ferry, Wythe Co., July, 1874, Shriver s.n. (G).

West Virginia: New River, Cotton Hill, Fayette Co., July 6, 1929, W.V.U. 1401 (WV).

North Carolina: valley of French Broad River, near Biltmore, Buncombe Co., June 21, 1898, Biltmore 5745a (MBG,US); along railway embankment, border of woods, near Bolton, Columbus Co., April 12, 1932, Palmer 39831 (NY); Little Yellow, Roan Mt., alt. 1675 m., Sept. 1, 1892, Merriam s.n. (US).

South Carolina: woods, Orangeburg, May 8, 1907, House 3331 (NY); Tomassee, Oconee Co., May 5, 1906, House 2006 (US); Sullivan's Island, May 23, 1887, Gibbes s.n. (NY); woods, near Vaucluse, Aug. 6, 1898, Eggert s.n. (MBG); moist places in the dunes, Phillip's Island, off Beaufort, April 28, 1917, Churchill s.n. (MBG); Charleston, date lacking, Gibbes s.n. (NY); W. of Columbia, June, 1894, MacFarlane $छ$ Davis s.n. (UP).

Georgia: banks of the Coosa, Rome, date lacking, Chapman s.n. (MBG); Stone Mountain, De Kalb Co., May 20, 1897, Eggert s.n. (MBG); Thompson's Mills and vicinity, Gwinnett Co., April 29, 1909, Allard 25 (US); between Alcovy River and No Business Creek, in Oconee and Gwinnett Cos., alt. 700-1000 ft., July 14, 1893, Small s.n. (NY,US); rich woods, Athens, May, 1897, Harper s.n. (NY); Ogeechee River, April 28, 1921, Harris C2188 (US); Jekyl Island, June, 1923, McAtee 3252 (US); McIntosh, April 7, 1926, Miller 510 (US); sand hills of Oconee River, Dublin, June 24, 1902, Harper 1370 (G).

Florida: hammock land, clay soil, vicinity of Eustis, Lake Co., May 1-15, 1894, Nash 610 (MBG,NY,US); East Pass, Sept. 1, 1899, Tracy 6387 (NY,US); Atseniota Island, Cedar Keys, March 24, 1926, Miller 385 (US); Madison Co., June-July, 1898, Hitchcock s.n. (MBG); in dry sandy field, St. Augustine, St. Johns Co., Nov. 19, 1929, Moldenke 166 (MBG, NY); in dry sandy pinewoods, Brooksville, Hernando Co., April 26, 1930, Moldenke 1078 (MBG); deep damp woodland, Hawkinsville, May 7, 1910, Hood s.n. (MBG); Duval Co., April 7, 1902, Fredholm 5040 (G); Port Orange, March 21, 1895, Straub $64(\mathrm{G})$; dense woodland on coast, near Smyrna, April 19, 1910, Hood s.n. (MBG); Miami, July, 1898, Hitchcock s.n. (FM); West Jupiter, April 10, 1904, Burgess 779 (FM).

Oнiо: Ashtabula, Ashtabula Co., June 24, 1899, Kellerman s.n. (OSU); St. Mary's, Auglaize Co., June 14-July 8, 1901, Wetzstein s.n. (OSU); Black Hand Gorge, Licking Co., July 7, 1930, Hicks s.n. (OSU); Ash Cave, Hocking Co., June 21, 1931, Bartley छे Pontius s.n. (OSU); Fairfield Co., 1892, Kellerman s.n. (OSU); escaped from cultivation ? Barnesville, Belmont Co., June 21, 1910, Laughlin s.n. (OSU); 7 mi. w. of Gallipolis, Gallia Co., Aug. 21, 1930, Hicks s.n. (OSU); Salem, Columbiana Co., June, 1900, Williamson s.n. (OSU); White Gulch, Jackson Co., May 24, 1925, Taylor s.n. (OSU); Agosta, Marion Co., June 26, 1930, Waller s.n. 
(OSU); on bank along road, Franklin Twp., Coshocton Co., May 29, 1931, Selby s.n. (OSU); Alexis, June 28, 1886, Young s.n. (G); Columbus, Sept. 1840, Sullivant $8 I$ (G); Dayton, date lacking, van Cleve s.n. (NY); on sand dunes on Cedar Pt., Erie Co., opposite Sandusky, July 12, 1903, Deam s.n. (D); r.r. track, Kipton, Loraine Co., July 23, 1895, Dick s.n. (O,OSU,UW); moist meadows, Mansfield, Richland Co., June 7, 1885, Wilkinson 10601 (O,OSU); York, Aug. 27, 1889, Leonard s.n. (O); meadows woods, and borders of thickets, Urbana, June 4, 1838, Samples s.n. (Mich.)

Michigan: Ann Arbor, June 28, 1862, Winchell s.n. (NY); Houghton, July 7, 1838, Thurber s.n. (NY); near Michigan Agricultural College, East Lansing, June 4, 1896, Beal s.n. (US); Harsens Island, St. Clair Co., July 11, 1904, Dodge s.n. (US); open ground, sand dunes along Lake Michigan, near Stevensville, Berrien Co., June 20, 1933, Palmer 40509 (MBG); s. of Marshall, Aug. 2, 1898, Beal s.n. (MSC); near Grass Lake, June 3, 1898, Lough s.n. (MSC); vicinity of North Muskegon, June 25, 1900, McLouth s.n. (MSC); sandy bank, Keeler, Van Buren Co., Aug., 1905, Pepoon 542 (MSC); Barron Lake, June 2, 1890, Wheeler s.n. (MSC); White Pigeon, July 6, 1903, Beal s.n. (MSC); Lamberton Lake, Grand Rapids, July 28, 1895, Shaddick E Skeels s.n. (MSC); dry fields, Gibralta, June 16, year lacking, collector unknown (Mich.).

Indiana: near Lake Maxinkuckee, July 8, 1899, Evermann 696 (US); Miller, Sept. 4, 1897, Moffatt 467 (US); Clarke, May 16, 1896, Umbach s.n. (US); 2 mi. south of Fort Wayne, June 24, 1906, Deam 1138 (D,US); Roby, July 21, 1907, Greenman 1954 (MBG); gravelly hillside on east side of Hogback Lake, Stueben Co., July 24, 1906, Deam 1266 (MBG,D, NY); Wawasee, Aug. 23, 1915, Pennell 6460 (NY); in sandy soil along the roadside $3 \mathrm{mi}$. west of Mt. Vernon, Posey Co., Deam 16812 (D); near Lafayette, along fence-rows, Tippecanoe Co., June 11, 1900, Dorner s.n. (D); sandy roadsides $1 \mathrm{mi}$. west of Laketon, Wabash Co., July 16, 1920, Deam 31920 (D); along the roadside about 3 miles northeast of Fowler, Benton Co., July 31, 1912, Deam 11845 (D); along the roadside about 21/2 miles southwest of Bicknell, June 7, 1912, Deam 11049 (D); also represented in the herbarium of Mr. Deam from Cass, Fulton, Gibson, Greene, Jasper, Kosciusko, Lagrange, Marshall, Newton, Noble, Porter, Pulaski, Starke, White, and Whittley counties.

Wisconsin: Waupaca, 1907, Garesche s.n. (MBG); dry sand at foot of Lake Pepin, Pepin Co., Aug. 2, 1926, Fassett 3300 (NY); wooded hills and on limestone rocks, near Richland Center, Richland Co., June 6, 1912, Lansing 3405 (US); vicinity of Delavan, July 13, 1919, Hollister 36 (US); vicinity of Kilbourn, Sauk Co., on the Wisconsin River, alt. 270 m., Aug. 25, 1909, Steele 27 (US); St. Anthony, June 18, 1888, Schuette s.n. (NY,US); Camp Douglas, July 15-Sept. 13, 1890, Mearns s.n. (NY,US); Trempeleau Valley, July, 1891, Schuette s.n. (FM); Plover, July 26, 1888, Schuette s.n. (FM); Green Lake, Aug. 13, 1899, Schuette s.n. (FM); Viroqua, Vernon Co., July 12, 1922, Smith 7228 (UW); Black River Falls, Jackson Co., June 28, 1922, Smith 6872 (UW); Pine Bluff, Dane Co., July 16,1929, Oelmiller s.n. (UW); sandy soil, Evansville, Rock Co., June 7, 1930, Hansen s.n. (UW); bluffs opposite Dubuque, Ia., Grant Co., May 30, 1930, Fas- 
sett 15107 (UW); wooded dune, French Id., Oualaska, La Crosse Co., Aug. 22, 1927, Fassett 5107 (UW); Lake Denoon, Muskego, Waukesha Co., July 2, 1928, Ehrler s.n. (UW); roadside, Arena, Iowa Co., June 15, 1929, Breakey s.n. (UW); rich ground, Wauwatosa, July 23, 1893, Dietz s.n. (UW); along lake shore, Menomonie, Dunn Co., July 13, 1928, Bachmann छ Patrick s.n. (UW); near Drummond, June 24, 1896, Cheney 4203 (UW); valley of the Wisconsin River near Linwood Ferry, Portage Co., July 5, 1894, Cheney 3569 (UW); Argyle, LaFayette Co., Aug., Anderson s.n. (UW); waste field, Fall Creek, Eau Claire Co., July 3, 1928, King 50 (UW).

Illinois: Along R.R., Wheaton, June 26, 1892, Moffatt 155 1/2 (US); Adams Co., June 24, 1842, Holton s.n. (NY); sandy soil, Rock Island Arsenal, May 21, 1891, Lyon s.n. (US); Joliet, June 28, 1904, Skeels 364 (US); French Village, St. Clair Co., May 14, 1878, Eggert s.n. (MBG,NY, US); Oregon, Ogle Co., June 2, 1885, Waite s.n. (US); "Bird Haven", 21/2 miles north of Olney, Richland Co., June 1, 1910, Ridgway s.n. (FM, US); dry open meadow, vicinity of Kankakee, June 8, 1913, Crampton 139 (US); prairie west of Turner, June 26, 1897, Moffatt s.n. (US); thickets, Carlinville, Macoupin Co., July 29, 1897, Moffatt 302 (US); Stony Island, Cook Co., June 30, 1914, Smith 5956 (G,MBG); Urbana, May 20, 1909, Pease 11940 (G); Union Co., May 6, 1902, Gleason s.n. (G); Portage, Jo Davies Co., grassy railroad embankment, in rich soil, June 18, 1917, Lansing 4094 (ANSP,FM,MBG); Ottawa, La Salle Co., June 8, 1918, King 437 (FM); Carthage, Hancock Co., May 28, 1916, Gates 8847 (FM); sandy barrens near Oquawka, exact date lacking, Patterson s.n. (FM); Waukegan, June 16, 1909, Gates 3022 (FM); dry bank, Wady Petra, June 3, 1900, Chase 645 (FM); Steward, June 26, 1907, Beck 26980 (UW).

Kentucky: Kuttawa, Lyon Co., June 2-8, 1909, Eggleston 4578 (NY).

Tennessee: limestone bluffs along the Cumberland River, Nashville, May 19, 1900, Biltmore 5745d (ANSP).

Alabama: Auburn, Lee Co., June 5, 1897, Earle छ Baker 565 (FM, MBG,NY,O); Tallapoosa, Aug. 22, 1897, Earle s.n. (NY); dry roadsides, Glass Mill, Macon Co., Sept. 23, 1899, Earle 2201 (NY); Tuskaloosa, Apr.-June, 1872, Mohr s.n. (US); dry oak clearing, 8 mi. north of Headland, Henry Co., Aug. 11, 1927, Wiegand छ Manning 717 (C).

Mississippi: Macon, June 1, 1897, Tracy 3229 (NY); Biloxi, March 31, 1898, Tracy 5127 (NY,US); Starkville, April 22, 1896, Tracy 3086 (NY); Mayhew, May 9, 1927, Cook s.n. (UP).

Minnesota: Winona, July, 1912, Freiburg s.n. (MBG); Jefferson, Houston Co., July 25, 1899, Wheeler 410 (UM); roadsides, sandy soil, about 5 miles west of Rushford, June 21, 1915, Rosendahl छ Butters 2978 (UM).

Iowa: below bluffs along river, Park Ridge, July 9, 1905, Walker s.n. (US); damp sandy soil, Johnson Co., June 28, 1894, Fitzpatrick s.n. (NY); fields, Bentonsport, July, 1920, Graves 1941 (MBG); sandy soil, roadside, Black Hawk Co., June 6, 1929, Burk 278 (MBG); Sugar Creek, Lee Co., May 19, 1914, Davis 2358 (MBG); Iowa City, date lacking, Hitchcock s.n. (MBG); rich soil, Decatur Co., July 4, 1903, Anderson s.n. (MBG); 
prairies, near Columbus, Louisa Co., June 24, 1933, Palmer 40564 (MBG); Vinton, date lacking, Davis s.n. (UW); gravelly terrace along R.R. and road, s.w. of New Albin, Allamakee Co., Aug. 1, 1919, Shimek s.n. (I); sandy alluvial plain, east of Fruitland, Muscatine Co., June 10, 1928, Shimek s.n. (I); prairie along R.R., Calmar, Winneshiek Co., July 17, 1903, Shimek s.n. (I); prairie border along road in woods, north of Homestead, Iowa Co., June 5, 1920, Shimek s.n. (I); prairie along Ill. Cent. Ry., 1 mi. west of Delaware, Delaware Co., May 31, 1935, Shimek s.n. (I); prairie opening on St. Peter sandstone slope below Pike's Hill, near McGregor, Clayton Co., June 3, 1921, Shimek s.n. (I); prairie remnants near Centerville, Appanoose Co., May 15, 1902, Shimek s.n. (I).

Missouri: St. Francis River, near Silvermine, Madison Co., May 20, 1927, Greenman s.n. (ANSP,MBG); railway right-of-way, Webster Groves, St. Louis Co., May, 1925, Woodson 195 (MBG); Potosi, Washington Co., June 31, 1892, Dewart s.n. (MBG); shore of Lake Killarney, near Arcadia, Iron Co., May 8, 1925, Woodson 326 (MBG); rocky open ground, along small stream, near Ava, Douglas Co., June 26, 1928, Palmer 34712 (MBG); Jefferson City, Cole Co., June, 1866, Krause s.n. (MBG); rich woods, Swan, May 18, 1907, Bush 4547 (MBG); Montier, May 15, 1894, Bush 551 (MBG); Gray Summit, Franklin Co., May 24, 1928, Kellogg 1650 (MBG); Independence, Jackson Co., June 25, 1892, Bush 2568 (MBG,NY); common on prairies, Carthage, May 10, 1902, Palmer 657 (MBG); Jerome, May 26, 1914, Kellogg 542 (MBG); McCune Sta., Pike Co., damp banks, May 20, 1919, Davis 4402 (MBG); railway tracks, Moscow, Lincoln Co., May 27, 1916, Davis 1270 (MBG); common in rocky soil, Saginaw, Newton Co., July 1, 1906, Palmer s.n. (MBG); near Mark Twain's Cave, Marion Co., damp soil, July 3, 1915, Davis 5713 (MBG); prairie northeast of town, Springfield, Aug. 21, 1912, Standley 9138 (US); Mansfield, alt. 1480 ft., June 5-12, 1911, Lansing 3121 (FM,G); prairies, near Mexico, Audrain Co., June 28, 1933, Palmer and Steyermark 40790 (MBG); upland prairies, near Eagleville, Harrison Co., July 6, 1933, Palmer E Steyermark 41337 (MBG); upland prairies, between Laclede and Linneus, Linn Co., July 4, 1933, Palmer E Steyermark 41227 (MBG); sand, Commerce, Aug. 23, 1927, Kincaid s.n. (Mo.); hillsides, Columbia, July 1, 1902, Daniels s.n. (Mo); wet places, Kennett, July 21, 1900, Dimmitt 339 (Mo); Macon, June 9, 1891, Grover s.n. (O).

Arkansas: common in woods, Eureka Spring, May 8, 1902, Bush 1527 (MBG); woods near Texarkana, Miller Co., June 9, 1898, Eggert s.n. (MBG); Pettigrew, Madison Co., May 31, 1910, Howell 669 (US); roadsides near Searcy, White Co., Woodson E' Hubricht s.n. (MBG); Benton Co., Aug., 1889, Heacox s.n. (O); common along R.R. I/2 mi. N. of Waldenburg, Poinsett Co., April 30, 1935, Hubricht s.n. (MBG); summit of Rich Mt., Polk Co., April 28, 1935, Heinze s.n. (MBG); Lonoke Co., April 20, 1921, Buchholz s.n. (Ark); open woods and exposed places, Ponca, Newton Co., May 14, 1932, Moore 32328 (Ark); moist sandy soil, border of woods, near Malvern, Hot Springs Co., April 18, 1926, Palmer 29697 (Ark); Fayetteville, June 9, 1931, Pyle 625 (Ark).

Louisiana: open ground, Myrtle Grove, March 13, 1930, Benke 5522 (FM); sandy soil, Shreveport, June, 1908, Cocks s.n. (TU). 
Nebraska: Fremont, June 5, 1901, MacDougal 1 (NY); hills on White River, May 22, 1854, Hayden s.n. (MBG); Lincoln, July 23, 1906, Univ, Nebr. Herb. 457 (T); low land near water, Fairbury, collector unknown 23 (UN).

Kansas: along road, between Pleasanton and Prescott, June 20, 1929, Rydberg Eं Imler 111 (NY); Oswego, bluffs $1 \mathrm{mi}$. north of town, June 27, 1929, Rydberg E Imler 339 (MBG,NY); Republican Fork of the Kansas River above Fort Riley, June 29, 1856, Engelmann s.n. (MBG); Manhattan, Aug. 25, 1892, Norton s.n. (MBG); Winfield, date lacking, Carter s.n. (MBG); sandy soil, Lindsborg, July, 1888, Bodin s.n. (UM); Sedgwick Co., July 3, 1933, Wichita Univ. $570(\mathrm{~K})$; along railroads, Anderson Co., July 22, 1929, Harr s.n. (K); hill slope, Dickinson Co., June 15, 1929, Imler s.n. (K); sloping grassland, loam, Pottawatomie Co., June 13, 1929, Imler s.n. (K); Douglas Co., May, year lacking, Snow s.n. (K); Burlington, Coffee Co., July, 1896, Wimpey s.n. (KSAC); Liberal, Seward Co., May 10,1930 , Vickers s.n. (KSAC); in prairie southeast of Yates Center, Woodson Co., July 2, 1928, Rogers 31 (KSAC); Morris Co., July, 1895, Hitchcock s.n. (KSAC); Doniphan Co., July 31, 1897, Clothier $\xi^{\circ}$ Whitford s.n. (KSAC); in meadow south of Monmouth, Cherokee Co., June 22, 1929, Jacobs 56 (KSAC); rocky soil along roadside near Hillsdale, Miami Co., May, 1925, Roofe s.n. (KSAC); Montgomery Co., Aug., 1896, Hitchcock s.n. (KSAC); Franklin Co., July, 1896, Hitchcock s.n. (KSAC); Johnson Co., Aug. 7, 1897, Clothier छे Whitford s.n. (KSAC); Chautauqua Co., Aug. 3, 1896, Hitchcock s.n. (KSAC); Neosho Co., July, 1896, Hitchcock s.n. (KSAC); Roper, Wilson Co., May 14, 1896, Haller s.n. (KSAC); Leavenworth Co., May, 1896, Hitchcock s.n. (KSAC); roadside northwest of Auburn, Shawnee Co., Maus s.n. (KSAC); Saline Co., June, 1896, Hitchcock s.n. (KSAC); sandy soil, Riley Co., May 25, 1895, Norton 526 (KSAC); White Water, Butler Co., July, 1892, Hitchcock s.n. (KSAC); near Altamont, Labette Co., May 9, 1924, Nelson s.n. (KSAC); Ft. Scott, Bourbon Co., May 28, 1893, Bennett s.n. (KSAC); Cloud Co., Fraser 60 (UW).

Oкцанома: Arbuckle Mts., Crusher, May 12, 1916, Emig 573 (MBG); vicinity of Ft. Sill, May 8, 1916, Clemens 11521 (MBG); in woods, near Page, Le Flore Co., May 20, 1914, Blakley 1490 (MBG); Sapulpa, April 29, 1895, Bush 472 (MBG); Keechie Hills, June 30, 1903, V an Vleet s.n. (UO,US); Garnett, May 15, 1926, Greene s.n. (US); open woods, east of Gowen, June 12, 1930, Clark 2697 (UO); prairies, w. of Idabel, May 15, 1930, Sears 1436 (UO); rocky soil, wooded hillside, Muskogee Co., April 17, 1927, Little 593 (UO); both clay and sandy soil, common in timber, fifteen miles east of Norman, May 4, 1921, Jeffs s.n. (UO).

Texas: Tarrant Co., along R.R. east of Polytechnic, May 2, 1919, Ruth 766 (FM,G,MBG,NY); prairies, near Victoria, Victoria Co., April 6, 1900, Eggert s.n. (MBG); prairies near Buchanan, Bowie Co., June 13, 1898, Eggert s.n. (MBG); common in sand, Mineola, April 24, 1901, Reverchon 2483 (MBG,NY); Columbia, April 12, 1899, Bush 135 (MBG); swamps, Swan, June 3, 1903, Reverchon 4050 (MBG); sandy open ground, Bryan, Brazos Co., May 29, 1915, Palmer 7803 (MBG); prairie, Houston, April, 1862, Lindheimer 174 (MBG); prairies near Colorado, Mitchell Co., 
June 9, 1900, Eggert s.n. (MBG); Denison, April 21, 1906, Reverchon s.n. (MBG); Corsicana, April 25, 1902, Reverchon 2768 (MBG,NY); South Dallas, April, 1900, Reverchon 2188 (MBG,NY); Van Zandt Co., Spring, 1930, Peckham s.n. (T); Austin, May 3, 1930, Tharp s.n. (T); Montague Co., June 19, 1929, Tharp s.n. (T); Marsh, Gonzales Co., May 3, 1930, Tharp s.n. (T); Goodman Pasture, Bastrop, April, 1928, Duval s.n. (T); near Corpus Christi, March, 1894, Heller s.n. (NY); Leonard, Collins Co., May 1, 1886, Merrill s.n. (NY); Industry, 1895, Wurzlow s.n. (US); Port Arthur, May 10, 1927, Kolthoff s.n. (US).

The most variable character of $T$. canaliculata is the color of the petals, which range through innumerable shades from purple and blue to various shades of rose. Pure white flowers are relatively rare, and when found, are nearly always accompanied by pale blue filaments. Very rarely one is able also to find flowers with white filaments. An unusual feature of the petals of this species is also the occasional variegated colors, such as petals with a white ground, and blue-tinted margins. The color of the flowers has appeared too complicated and variable to form even the basis of forms and varieties in this study.

Another interesting feature of $T$. canaliculata is the occasional presence of eglandular hairs upon the sepal-tips and sheaths of lower leaves. The barbate sepals are evidently undeserving of taxonomic distinction, or of no more than subspecific designation, occurring in a wide range of intergradations with plants bearing absolutely glabrous sepals: occasionally upon the same plants. It has been found that the sheaths of early spring and autumn leaves are more frequently apt to be hairy than those of the summer foliage, and this character can obviously not be used as the basis of taxonomic units. Moreover, it has been found that in the garden inflorescences of this species not infrequently produce viviparous or adventitious shoots in late summer or autumn, the young leaves of which are distinctly pilose.

In resurrecting T.reflexa Rafinesque in 1897,Dr. Small was fully aware of the pre-existence of $T$. canaliculata, which he doubtfully assigned to synonymy under the former species, chosen in preference to the earlier name with the explanation " $I$ have adopted the specific name reflexa of Rafinesque because the original description agrees fairly well with the specimens I have collected in the Southern States and the original locality lies within the bounds of the range shown by my specimens" (Small in Bull. Torrey Bot. Club, 24:232-233. 1897). As the description of $T$. canaliculata Rafinesque is quite as good, or rather no 
less inadequate, for our plants as that of $T$. reflexa, the use of the earlier name is indubitably prescribed by the existing rules governing nomenclature.

10. Tradescantia paludosa, sp. nov.

(Plates II, fig. 4; IV, fig. 6; XI)

Planta habitu $T$. canaliculatam Rafinesque simulans, radicibus sat tenuibus crassiusculis glabratis; caulibus erectis vel ascendentibus non raro plus minusve decumbentibus plerisque ramosis $3-4 \mathrm{dm}$. altis glaberrimis haud glaucescentibus; nodis $5-7$; internodiis 4-11 cm. longis; foliis membranaceis dilute viridibus sed haud glaucescentibus, lamina anguste oblongo-elliptica vel lineari-lanceolata acuminata basi in vaginam plerumque plus minusve constricta $4-11 \mathrm{~cm}$. longa $0.4-1.2 \mathrm{~cm}$. lata glaberrima patula vel paullulo ascendenti, vagina $0.5-2.0 \mathrm{~cm}$. longa $0.4-2.0$ $\mathrm{cm}$. lata; cymis umbellatis pauci vel plurifloris terminalibus solitariis vel saepius etiam lateralibus pedunculatis; bracteis foliaceis $2-10 \mathrm{~cm}$. longis $0.3-0.8 \mathrm{~cm}$. latis glabris patulis; pedicellis $1.0-1.5 \mathrm{~cm}$. longis glabris post maturitatem reflexis paulo accrescentibus; sepalis ellipticis acutis acuminatisve $0.6-0.7 \mathrm{~cm}$. longis dilutissime viridibus vix glaucescentibus glaberrimis; petalis ovatis $1.3-1.5 \mathrm{~cm}$. longis dilute caeruleis; filamentis pilosis connectivo late trapezoideo; ovario ovoideo glabro vel apice eglandulo-barbato; capsulis obovoideo-oblongoideis 0.2 $0.5 \mathrm{~cm}$. longis; seminibus plane oblongoideis $0.2-0.3 \mathrm{~cm}$. longis funiculo lineari semen paene aequante.

Roots relatively slender, somewhat fleshy, glabrate; stems erect or ascending, not infrequently more or less decumbent, usually more or less branching, $3-4 \mathrm{dm}$. tall, glabrous, not glaucous; nodes 5-7; internodes $4-11 \mathrm{~cm}$. long; leaves membranaceous pale green but not glaucous, the blade narrowly oblong-elliptic to linear-lanceolate, acuminate, base usually more or less constricted into a subpetiolar base, 4-11 cm. long, $0.4-1.2 \mathrm{~cm}$. broad; glabrous, spreading, or very slightly ascending, stomata predominantly restricted to the lower surface, the sheath $0.5-2.0$ $\mathrm{cm}$. long, $0.4-2.0 \mathrm{~cm}$. broad; cymes umbellate, few- to severalflowered, terminal, solitary, or more frequently also lateral and pedunculate at the upper nodes; bracts foliaceous, $2-10 \mathrm{~cm}$. long, $0.3-0.8 \mathrm{~cm}$. broad, glabrous, spreading; pedicels $1.0-1.5 \mathrm{~cm}$. long, glabrous, reflexed and somewhat accrescent after maturity; sepals elliptic, acute to acuminate, $0.6-0.7 \mathrm{~cm}$. long, very pale 
green, not glaucescent, glabrous; petals ovate, $1.3-1.5 \mathrm{~cm}$. long, pale blue; filaments abundantly pilose, connective broadly trapezoid; ovary ovoid, glabrous, or eglandular-barbate at the base of the style; capsules obovoid-oblongoid, $0.2-0.5 \mathrm{~cm}$. long; seeds compressed-oblongoid, $0.2-0.3 \mathrm{~cm}$. long, the funicular scar linear, about as long as the seed.

Alluvial bottoms and forests, southern Alabama and Louisiana, apparently ascending the bottoms of the lower Mississippi to southern Arkansas (Desha Co.). The commonest species in the vicinity of New Orleans, where it spreads to roadsides and railroad right-of-ways.

Map 10.

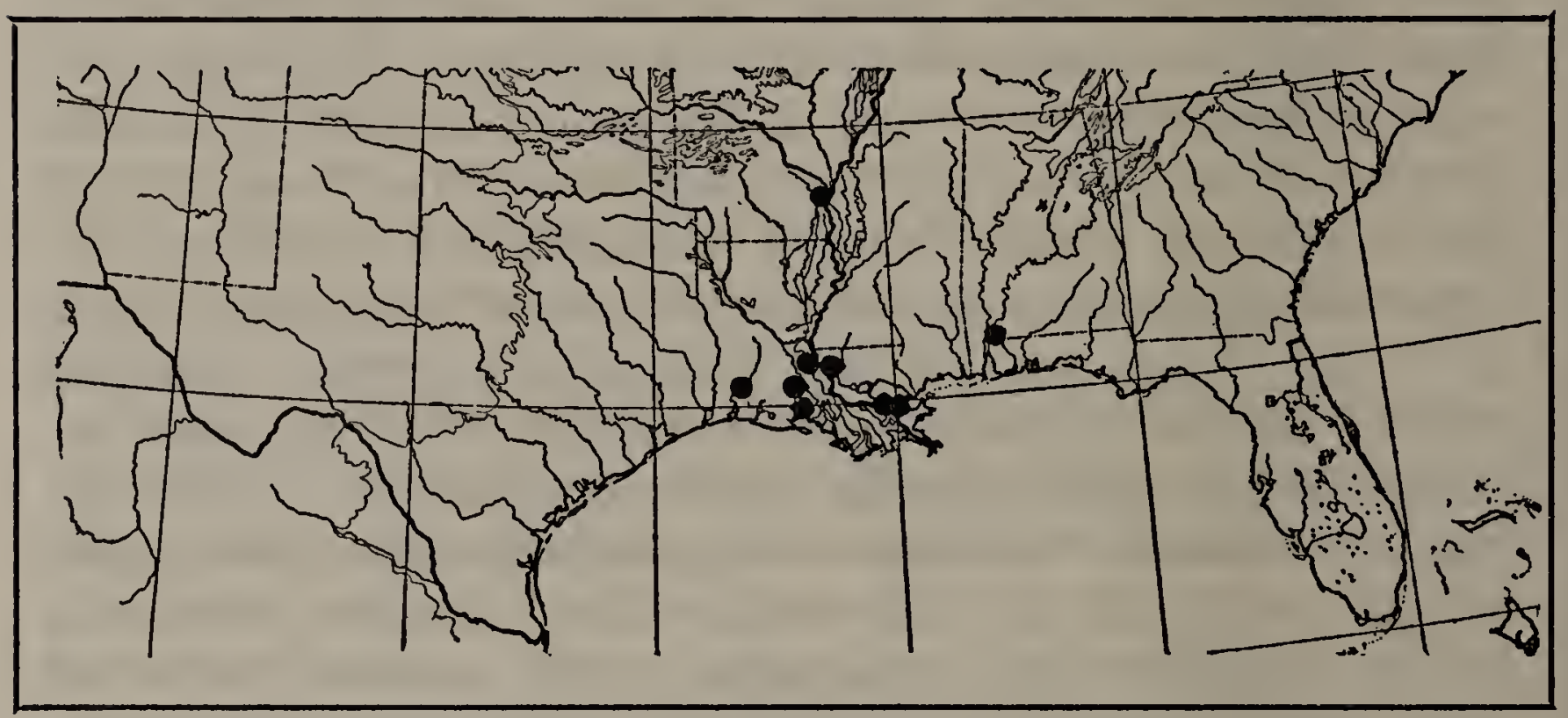

Map 10. Range of Tradescantia paludosa.

Alabama: abundant in alluvial bottoms of Mobile River in Baldwin Co. opposite Mount Vernon, May 16, 1927, Harper 21 (MBG,NY,US).

Arkansas: common in alluvial forest, Desha Co., May 10, 1894, Mohr s.n. (US).

Louisiana: full sun, deep cinders along R.R. bordering swamps, near Gentilly, Orleans Parish, Jan. 1, 1932, Small Anderson छे Woodson s.n. (ANSP,MBG, TYPE, FM,G,NY,US); vicinity of Lake Charles, 1904, Allison 316 (NY,US); along Chef Menteur Highway, about 2 miles from Gentilly, exceedingly common, March 26, 1933, Haas s.n. (MBG); partly cleared woods, Crowley, Apr. 10, 1910, Cocks s.n. (TU); roadside, New Roads, Pointe Coupee Parish, April 2, 1933, Chaney 387 (LSU); ditch bank, Franklin, St. Mary Parish, March 14, 1933, Bynum Ingram छ Jaynes s.n. (LSU); Baton Rouge, East Baton Rouge Parish, March 1, 1927, Brown 915 (LSU).

At first glance the only characteristic which distinguishes this species from $T$. canaliculata may appear to be its somewhat lower and more diffuse habit. The leaves, however, are smaller, 
on the whole, than in the latter species, and are of a different shape, the blade being more or less constricted into a base somewhat narrower than the sheath, and the blade itself is predominantly about as broad as the sheath, at least the uppermost. Another character in sharp contrast to $T$. canaliculata is the fact that the plants are not glaucous, one of the most striking characteristics of that species. This difference in color is due, at least in the case of the foliage, to the fact that the upper leafsurface is practically devoid of stomata, as in the tropical Commelinaceae in general, whereas in $T$. canaliculata the stomata are about equally numerous upon both upper and lower leafsurfaces. The other vegetative and floral organs are somewhat smaller in $T$. paludosa than in $T$. canaliculata.

The apparently interrupted distribution of this species in the lowlands of southeastern Arkansas, may possibly be not so in fact, as the lower Mississippi Valley is one of the regions of the United States most in need of botanical knowledge at the present.

\section{Tradescantia bracteata Small}

(Plates III, fig. 1; VI, fig. 1; VII, fig. 5)

Roots relatively slender, somewhat fleshy, glabrate, or inconspicuously and irregularly pilose, usually pale orange-colored; stems erect or ascending, straight, not flexuose, branching rather infrequently, $0.5-4.4 \mathrm{dm}$. tall, glabrous, or rarely minutely puberulent above; nodes 2-4; internodes $1-17 \mathrm{~cm}$. long; leaves firmly membranaceous, bright (usually yellowish-) green, not glaucous, the blade linear-lanceolate, long-acuminate, $15-29 \mathrm{~cm}$. long, $0.9-2.0 \mathrm{~cm}$. broad, glabrous, stiff, and more or less reflexed or falcate, stomata somewhat more numerous upon the lower than the upper surface, the sheath rather turgid and inflated, 0.9-3.7 cm. long, 0.9-3.5 cm. broad; cymes umbellate, few- to many-flowered, terminal, solitary, or infrequently lateral and pedunculate at the upper nodes; bracts foliaceous, $9-27 \mathrm{~cm}$. long, $1.4-2.2 \mathrm{~cm}$. broad, glabrous, or rarely somewhat minutely puberulent upon the sheath, rather stiff and more or less recurved or falcate; pedicels $1.8-3.3 \mathrm{~cm}$. long, conspicuously pubescent with glandular and eglandular hairs interspersed, reflexed and somewhat accrescent in fruit; sepals rather broadly elliptic, acute, $1.0-1.3 \mathrm{~cm}$. long, densely and rather sordidly pubescent with viscid glandular and eglandular hairs interspersed; petals ovate, $1.8-1.9 \mathrm{~cm}$. long, usually bright rose, somewhat less fre- 
quently blue; filaments abundantly pilose, connective broadly trapezoid; ovary ovoid, uniformly glandular- and eglandularpubescent as in the sepals; capsules obovoid-oblongoid, 0.5$0.6 \mathrm{~cm}$. long; seeds roughly compressed-oblongoid, $0.2-0.3 \mathrm{~cm}$. long, the funicular scar linear, about as long as the seed.

Tradescantia bracteata Small in Britton \& Brown, Ill. Fl. ed. 1, 3: 510 (1898). - Britton, Man., 241 (1901). - Robinson \& Fernald in Gray, Man. ed. 7, 265 (1908). - Small, Fl. Southeast. U.S., 238 (1903). - Rydberg, Fl. Rocky Mts. ed. 2, 145 (1922); Fl. Prairies \& Plains, 199 (1932).

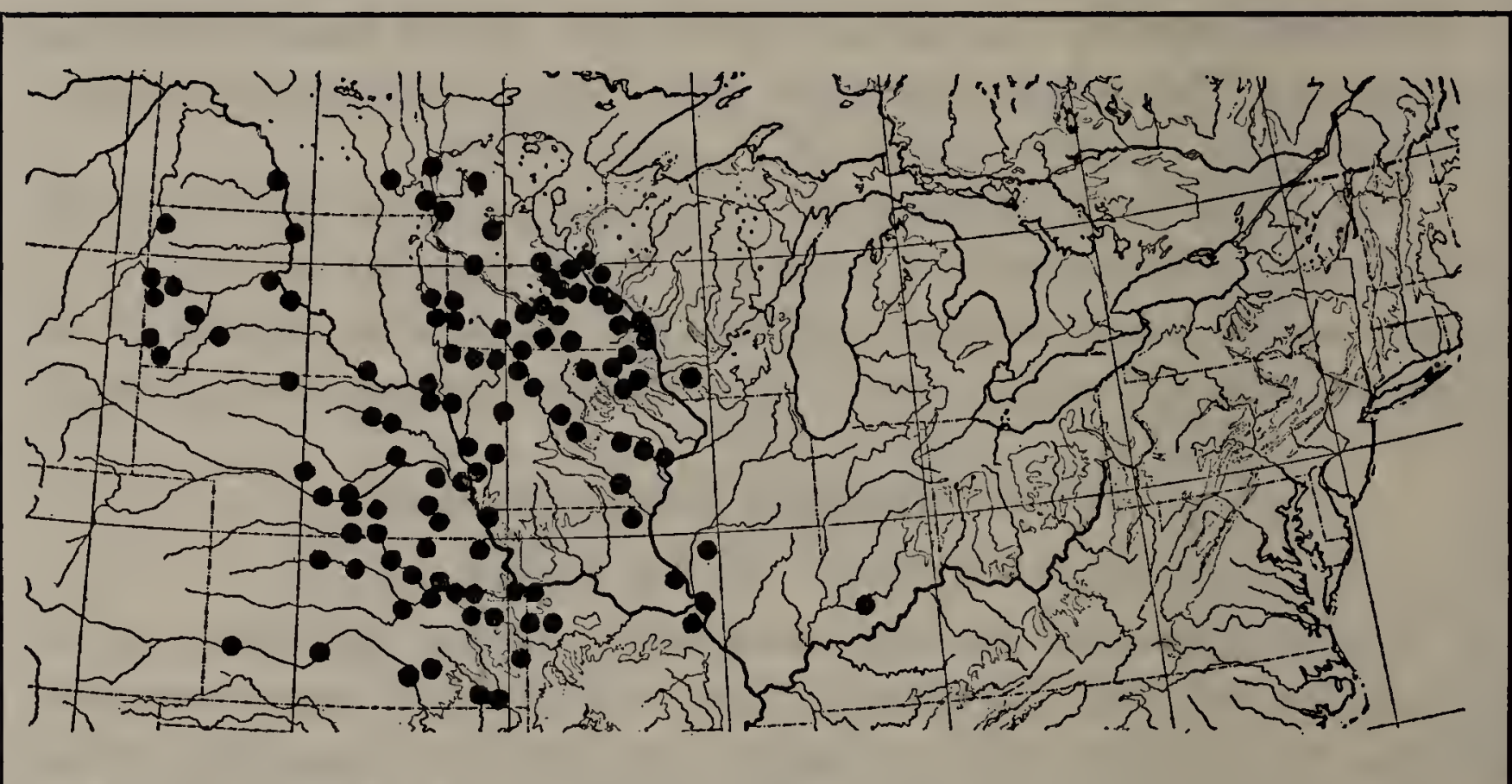

Map 11. Range of Tradescantia bracteata.

Prairies, spreading to thickets, roadsides, and railroad rightof-ways, Minnesota to northern and central Missouri, and westward to Montana and central Kansas; also locally in prairies of Illinois, Wisconsin, and Indiana.

MAP 11.

Indiana: French Lick Springs, April, 1877, Mason s.n. (FM).

Illinors: Morgan Co., June, 1869, Milligan s.n. (US).

Wisconsin: R.R. tracks, Avoca, Iowa Co., May 29, 1929, Davis s.n. (UW); sandstone bluff along L. St. Croix, $6 \mathrm{mi}$. south of Hudson, Aug. 2, 1934, Fassett 16617 (MBG,UW).

Minnesota: Litchfield, June, 1892, Frost s.n. (FM,UM); Groveland Park, Ramsey Co., May, 1895, Sheldon s.n. (UM,US); Nicollet, June, 1892, Ballard s.n. (UM,US); Ft. Snelling, June 4, 1891, Mearns s.n. (US); Houston Co., June, 1912, Freiburg s.n. (MBG); near Windom, June, 1914, Nelson s.n. (MBG,US); sandy soil, near Perham, Ottertail Co., June 7, 1912, Chandonnet s.n. (D,UM,US); Bluffs, Winona Co., July, 1907, Holzinger s.n. (NY); Ft. Armstrong, June 18-July, 1888, Schuette s.n. 
(G); Rochester, June 8, 1913, Thompson s.n. (G); sandy soil, oak copses, 5 miles w. of Northfield, Rice Co., June 14, 1915, Rosendahl छ Butters 2905 (C,UM); Idlewild, Lincoln Co., June, 1891, Wickersheim s.n. (UM); Glenwood, July, 1891, Taylor 783 (UM); Cannon Falls, June, 1881, Sandburg s.n. (UM); Pipestone City, 1892, Menzel s.n. (UM); Chaska, June, 1891, Ballard 58 (UM); Helena, Scott Co., June, 1891, Ballard 368 (UM); Red River valley, east of Breckenridge, June 18, 1921, Butters Johnson E" Rosendahl 4060 (UM): Lake City, June 19, 1883, Manning s.n. (UM); prairies, bluffs and valleys, common, Montevideo, June 7, 1885, Moyer s.n. (UM); Minnesota Lake, June, 1891, Taylor 578 (UM); Janesville, June, 1891, Taylor 176 (UM); Sleepy Eye, July, 1891, Sheldon 247 (UM); Moorhead, June 11, 1901, collector unknown (UM).

Iowa: woods, lake shore sand, Turtles Lake, May 30, 1925, Wolden 1079 a (G); Sac Co., June 18, 1888, Fitch s.n. (PC); Council Bluffs, June 21, 1853, Engelmann s.n. (MBG); prairie roadside, Black Hawk Co., June 19, 1929, Burk 382 (MBG); Sioux City, 1904, Hawkins s.n. (Mich.); Rock Creek, Jasper Co., May 8, 1886, Wilson s.n. (MBG); fields, frequent, Shelby Co., May 17, 1894, Fitzpatrick s.n. (RM); Winnisheik Co., June 20, 1895, Bartsch s.n. (US); sandy bottom lands along Cedar River, Muscatine Co., June 12, 1892, Reppert 655 (NY,US); Ft. Dodge, May 30, 1909, Somes s.n. (US); Charles City, June 11, 1874, Arthur 21 (NY); waste places, prairies, Fayette, July, 1893, Fink s.n. (G); Ames, 1877, Burgess 16 (CM); alluvial prairie south of Amana, Iowa Co., May 30, 1927, Shimek s.n. (I); prairie, west of Lake Park, Dickinson Co., June 22, 1930, Shimek s.n. (I); open bank, east of Ottumwa, Wapello Co., May 12, 1932, Shimek s.n. (I); prairie along R.R. north of Emmelsburg, Palo Alto Co., June 18, 1921, Shimek s.n. (I); upland prairie, north of Ocheyedan Mound, Osceola Co., July 10, 1912, Shimek s.n. (I); prairie along R.R. east of Iowa City, Johnson Co., May 29, 1928, Shimek s.n. (I); prairie along C.M.\&St.P.Ry., opposite Canton, S.D., Lyon Co., June 6, 1925, Shimek s.n. (I); prairie openings, northeast side of Buffalo Slough, Mason City, Cerro Gordo Co., June 25, 1921, Shimek s.n. (I); prairie banks, north of Missouri Valley, Harrison Co., June 14, 1909, Shimek s.n. (I).

Missouri: Davis Farm, near Dover, Pike Co., date lacking, Davis 4436 (MBG); Watson, June 1, 1894, Bush 684 (MBG,NY); Cass Co., June, 1865, Broadhead s.n. (MBG); common on prairies, Levasey, May 18, 1902, Bush 1683 (MBG,NY,US); near Chain of Rocks, St. Louis Co., May 14, 1933, Hubricht s.n. (MBG); dry open woods, Antonia, Jefferson Co., April 30, 1930, Kellogg s.n. (MBG); along north fork of Fabius River, west of Memphis, Scotland Co., June 30, 1933, Palmer छ Steyermark 40989 (MBG); Henry Co., July 2, 1892, Link s.n. (Mo.).

North Dakota: Richland Co., July 9, 1908, Bell 115 (MBG); prairie, Morton Co., June 25, 1907, Bell 95 (O); Valley City, July 10, 1897, Perrine s.n. (RM).

South Dakota: Missouri Valley, Glenham, June 16, 1908, Moyer s.n. (NY); sandy soil, Cascade Valley, May 24, 1930, McIntosh 1377 (NY); low grounds, near Brookings, June, 1892, Thornber s.n. (MBG); Box Elder Creek, Black Hills, June, 1887, Rusby s.n. (NY, TYPE); moist places, near 
Vermillion, June, 1910, Visher 4069 (MBG); Hot Springs, alt. $3500 \mathrm{ft}$., June 31, 1913, Rydberg 1053 (NY); rocky open ground, near Deadwood, Lawrence Co., June 11, 1929, Palmer 37172 (MBG); field, near Pringle, alt. 4800 ft., Aug. 15, 1908, Murdoch 3013 (FM,NY); bluff of Bellefourche, Butte Co., alt. 900 m., June 11, 1916, Eggleston 12502 (US); Charles Mix Co., May, 1895, McArthur 2 (US); Little Forest Farm, Flandrau, June 28, 1895, Perley s.n. (US); near Ft. Meade, Black Hills, May 16, 1887, Forwood 360 (US); sandy soil on grassy hillsides, Bear Creek, Washabaugh Co., June 1, 1914, Over 2085 (US); clay soil on tables under Saddle Pass, Stanley Co., June 6, 1914, Over 6043 (US); sandy fertile situations Missouri Valley, near Fort Pierre, June 16, 1839, Geyer s.n. (US); Antelope Valley, Harding Co., June 10, 1912, Visher 421 (FM).

Nebraska: Hastings, June 23, 1888, Thomson s.n. (FM); Ewing, May 18, 1896, Bates 468 (NY); Minden, May 31, 1929, Hapeman s.n. (ANSP); Wahoo, June, 1890, Rydberg s.n. (NY); sandy ground, Bloomington, June, 1891, Morrow s.n. (MBG); Crete, date lacking, Swezey s.n. (NY); Bellevue, June 8, 1853, Hayden s.n. (MBG); Fort Niobrara, June 14, 1888, Wilcox s.n. (NY); Newcastle, June 21, 1893, Clements 2591 (US); moist sandy soil, Beatrice, May 16, 1899, Washburn s.n. (US); Kearney, July, 1889, Holms s.n. (US); Neligh, May 11, 1896, Bacon s.n. (G); Callaway, May 21, 1901, Bates s.n. (G); Genoa, May 20, 1903, Curtis s.n. (UO); Red Cloud, Webster Co., May 28, 1903, Bates s.n. (UN); Overton, May 19, 1925, Jones s.n. (PC).

Kansas: moist "draw" near Osborne City, May, 1894, Shear 26 (US); Emporia, May 19, 1890, Tyler s.n. (MBG); Cowley Co., April, 1898, Lute s.n. (MBG); open ground, Montgomery Co., May 9, 1897, Hitchcock 5266 (MBG,NY,US); dry open soil, Rosedale, Wyandotte Co., date lacking, Mackenzie s.n. (D); Topeka, May 23, 1898, Harper Eं Harper s.n. (FM); Wichita, May, 1903, Poole 367 (G); in grassy slopes about a stock pond, near Rosalia, Butler Co., May 19, 1934, Heinze s.n. (MBG); Ottawa, May 16, 1890, Jones s.n. (O); southwest of Wabaunsee, Wabaunsee Co., May 9, 1927, Maus 179 (O); Bloom Twp., Clay Co., May 14, 1906, Schaffner s.n. (OSU); Geary Co., June, 1896, Hitchcock s.n. (KSAC); Brown Co., 1896, Lands s.n. (KSAC); herb in parking in Manhattan, Riley Co., May 20, 1922, Gates 13315 (KSAC); common on prairies, south of Bavaria, Saline Co., May 23, 1930, Hancin 262 (KSAC); Edwards Co., May, 1933, Finch s.n. (KSAC); near Altamont, Labette Co., May 9, 1924, Nelson s.n. (KSAC); Ft. Scott, Bourbon Co., May 28, 1893, Bennett s.n. (KSAC); Kearney Co., May 17, 1898, Clothier s.n. (KSAC); Osage Co., June 5, 1899, Brown s.n. (KSAC); Rockport, Rooks Co., May 27, 1889, Bartholomew 1 (KSAC); Cloud Co., 1930, Fraser 59 (KSAC); NW of Linn, Washington Co., 1933, Dodd s.n. (KSAC).

This well-marked species is one of the most natural of the genus. It is the only diploid species in the north and its lower chromosome number serves as a partial barrier between it and the tetraploid species with which it is associated. The lower chromosome number is also partially responsible for the greater 
frequency with which pure pink-flowered individuals are found in this species. These pink-flowered plants have bright, greenishyellow foliage while in blue-flowered individuals the cast of the foliage is much less yellowish. After their rather brief period of bloom, the pedicels and calyx wither to a dark brown, the stems and leaves turn yellow, and the whole plant quickly disappears. Although characteristic of other species in varying degree, the short life of the shoot of $T$. bracteata is particularly noteworthy and aids in the identification of the species in a well kept garden.

\section{Tradescantia hirsuticaulis Small}

(Plate VI, fig. 8)

Roots relatively slender, slightly fleshy, inconspicuously and irregularly pilose to glabrate; stems erect or ascending, straight, not flexuose, rather slender and weak, branching rather infrequently, $1.4-3.5 \mathrm{~cm}$. long, densely puberulent or pilose to glabrate; nodes 2-4; internodes 5-13 cm. long; leaves membranaceous, dull green, not glaucous, the blade linear-lanceolate, longacuminate, $12-25 \mathrm{~cm}$. long, $0.6-1.4 \mathrm{~cm}$. broad, rather lax and flaccid, irregularly pilose or puberulent to glabrate, stomata scattering upon the upper surface, less numerous than upon the lower, the sheath $0.5-2.0 \mathrm{~cm}$. long, $0.7-1.5 \mathrm{~cm}$. broad, pilose to puberulent, rarely glabrate; cymes umbellate, few- to severalflowered, terminal, solitary, or very infrequently lateral and pedunculate at the uppermost nodes toward the end of the season; bracts foliaceous, $5-16 \mathrm{~cm}$. long, $0.8-2.0 \mathrm{~cm}$. broad, rather lax and flaccid, irregularly pilose or puberulent, particularly at the base; pedicels $2.0-3.5 \mathrm{~cm}$. long, pubescent with eglandular and glandular hairs interspersed, pale green, or more frequently more or less rose-colored, reflexed and somewhat accrescent in fruit; sepals broadly elliptic, acute to acuminate, $0.7-1.1 \mathrm{~cm}$. long, more or less petalaceous, more or less suffused with rose or purple, less frequently delicately foliaceous, uniformly pubescent with glandular and eglandular hairs interspersed; petals ovate, $1.2-1.6 \mathrm{~cm}$. long, bright blue or rose; filaments abundantly pilose, connective broadly trapezoid; ovary ovoid, pubescent with glandular and eglandular hairs interspersed as in the sepals; capsules obovoid-oblongoid, $0.5-0.6 \mathrm{~cm}$. long; seeds roughly compressed-oblongoid, the funicular scar linear, about as long as the seed.

Tradescantia hirsuticaulis Small in Bull. Torrey Bot. Club, 24: 233 (1897); Fl. Southeast. U.S. 239 (1903) 
Rocky and sandy woods, thickets, and ledges, apparently also spreading to fields, southern Appalachian Mountains and western extensions, North Carolina, Georgia, Alabama, and Arkansas.

MAP 12.

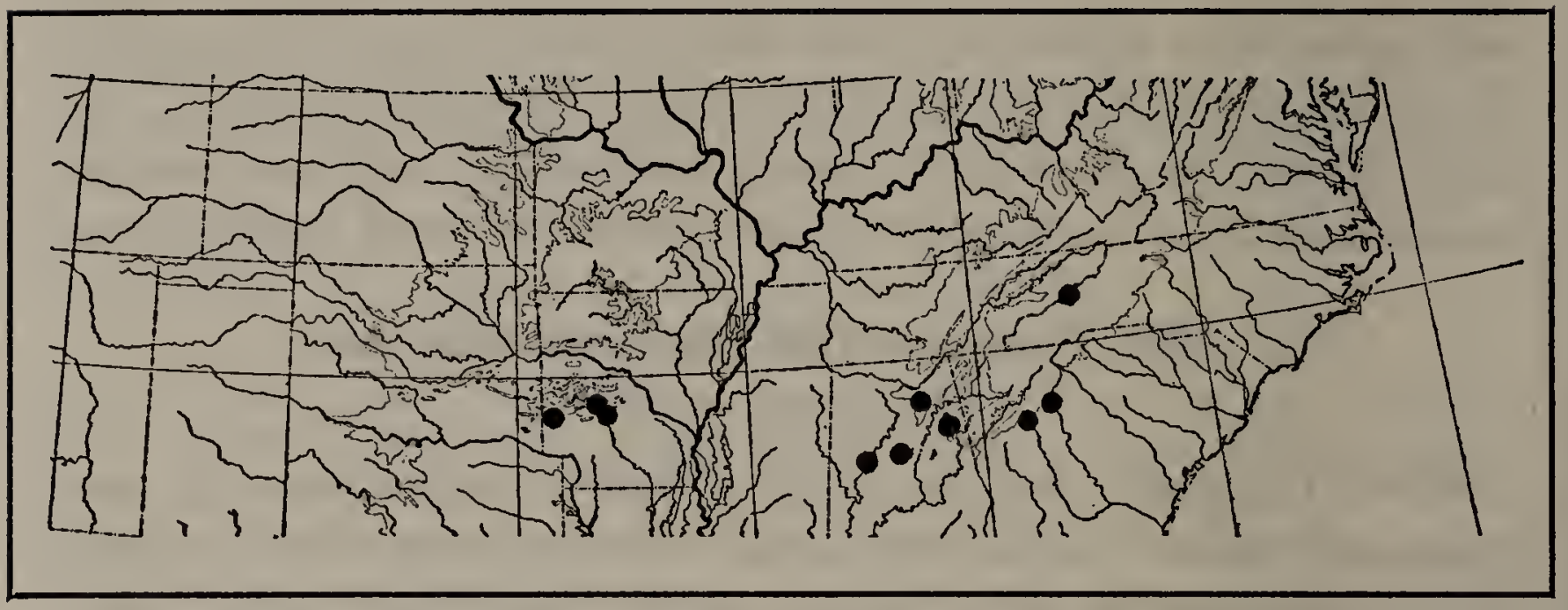

Map 12. Range of Tradescantia hirsuticaulis.

North Carolina: Hot Springs, May, 1889, Smith s.n. (ANSP); exact locality lacking, 1878, Vasey s.n. (US).

Georgia: Stone Mt., De Kalb Co., alt. 100-1500 ft., Small s.n. (FM, NY, TYPE); thin soil, and humus, along ledges, lower slopes of Stone Mountain, April 16, 1932, Palmer 39916 (N,Y); rocky field near Oconee River, Athens, alt. $600 \mathrm{ft}$. , May 15, 1897, Harper s.n. (NY).

Alabama: along rocky ledges, banks of creek, Shades Mountain, near Birmingham, Jefferson Co., April 19, 1931, Palmer 38963 (MBG); River Hills, n. slope, Tallapoosa Co., April 26, 1901, Earle s.n. (NY); wooded bank of stream on Sand Mountain, Albertsville, April 24, 1899, Hobden 1 (FM,NY); Jacksonville, Calhoun Co., May 4, 1933, Showalter s.n. (MBG).

Arkansas: dry woods near summit of West Mountain, alt. $1300 \mathrm{ft}$., about 3 miles west of Hot Springs, Garland Co., May 3, 1923, Harper 30 (ANSP,NY); moist ledges, rocky banks of Hot Springs Creek, near Hot Springs, Garland Co., April 22, 1924, Palmer 24461 (MBG); along clefts and ledges, porphyry bluffs of Cove Creek, Magnet Cove, Hot Springs Co., April 19, 1926, Palmer 29718 (P); Baker Springs, Howard Co., April 16, 1909, Kellogg s.n. (MBG).

This species is rather variable in the coloring of the petalaceous sepals. The suffusion of rose-color appears to be possibly more conspicuous in the Arkansas specimens than in those east of the Mississippi, although the tint has been found to vary among specimens from the same locality. The color also seems to be more intense in withering flowers which have failed to set seeds, the calyx of fertilized flowers becoming somewhat foliaceous for a short period during the early stages of seed-production. The 
texture of the petalaceous sepals of $T$. hirsuticaulis is somewhat more delicate than those of $T$. Tharpii and the following species. The geographical distribution of $T$. hirsuticaulis illustrates well the affinity of the flora of the southern Appalachian Mountains for that of their western extensions in the Ouachita Mountains of Arkansas and extreme eastern Oklahoma.

\section{Tradescantia longipes, sp. nov.}

(Plates V, fig. 10; VI, fig. 9; X)

Planta subacaulis T. Tharpii Anders. \& Woods. flore simulans; radicibus sat carnosis glabratis; caulibus erectis simplicibus $0.2-1.0 \mathrm{dm}$. longis, et planta saepe ut videtur subacaulis, longe pilosis villosissimisve; nodis $1-2$; internodiis $0.5-4.0 \mathrm{~cm}$. longis; foliis firme membranaceis atroviridibus haud glaucescentibus lamina lineari-lanceolata longe acuminata $14-22 \mathrm{~cm}$. longa $0.6-1.2 \mathrm{~cm}$. lata laxe irregulariterque pilosa patula vagina $0.1-$ $1.0 \mathrm{~cm}$. longa $1.0-1.9 \mathrm{~cm}$. lata ad basim caulis plerumque imbricata; cymis umbellatis pauci- vel multifloris terminalibus solitariis; bracteis foliaceis $16-25 \mathrm{~cm}$. longis $0.7-1.2 \mathrm{~cm}$. latis laxe ascendentibus vel paululo patulis; pedicellis gracillimis 4-6 $\mathrm{cm}$. longis purpureo-roseis laxe glanduloso-et eglanduloso-pilosis post maturitatem conspicue reflexis et paulo accrescentibus; sepalis late ellipticis acutis acuminatisve $0.8-1.0 \mathrm{~cm}$. longis aliquanto petalaceis purpureo-roseis margine hyalinis uniformiter laxeque glanduloso- et eglanduloso-pilosis; petalis late ovatis $1.0-1.5 \mathrm{~cm}$. longis roseis, caeruleis vel purpureis; filamentis pilosis connectivo late trapezoideo; ovario ovoideo uniforme glandulo- et eglandulo-pubescente quandoque fere glabrato; capsulis obovoideo-trigonalibus $0.4-0.6 \mathrm{~cm}$. longis; seminibus plane oblongoideis $0.2-0.3 \mathrm{~cm}$. longis funiculo lineari semen paene aequante.

Roots relatively fleshy, glabrate; stems erect, simple, and the plant often nearly acaulescent, $0.2-1.0 \mathrm{dm}$. tall, usually more or less buried in the substrate, long-pilose to villous; nodes $1-2$; internodes $0.5-4.0 \mathrm{~cm}$. long; leaves firmly membranaceous, deep green, not glaucous, the blade linear-lanceolate, long-acuminate, $14-22 \mathrm{~cm}$. long, $0.6-1.2 \mathrm{~cm}$. broad, laxly and irregularly pilose, stomata somewhat more numerous upon the lower than upon the upper surface, widely spreading, the sheath $0.5-1.0 \mathrm{~cm}$. long, $1.0-1.9 \mathrm{~cm}$. broad, usually more or less imbricated at the base of the stem; cymes umbellate, few- to many-flowered, terminal, 
solitary; bracts foliaceous, $16-25 \mathrm{~cm}$. long, $0.7-1.2 \mathrm{~cm}$. broad, laxly ascending or slightly spreading; pedicels very long and slender, $4-6 \mathrm{~cm}$. long, purplish-rose, conspicuously reflexed and somewhat accrescent after maturity; sepals broadly elliptic, acute to acuminate, $0.8-1.0 \mathrm{~cm}$. long, somewhat petalaceous, purplish-rose, margins hyaline, uniformly and laxly glandularand eglandular-pilose interspersed; petals broadly ovate, 1.0-1.5 $\mathrm{cm}$. long, rose, blue, or purplish; filaments abundantly pilose,

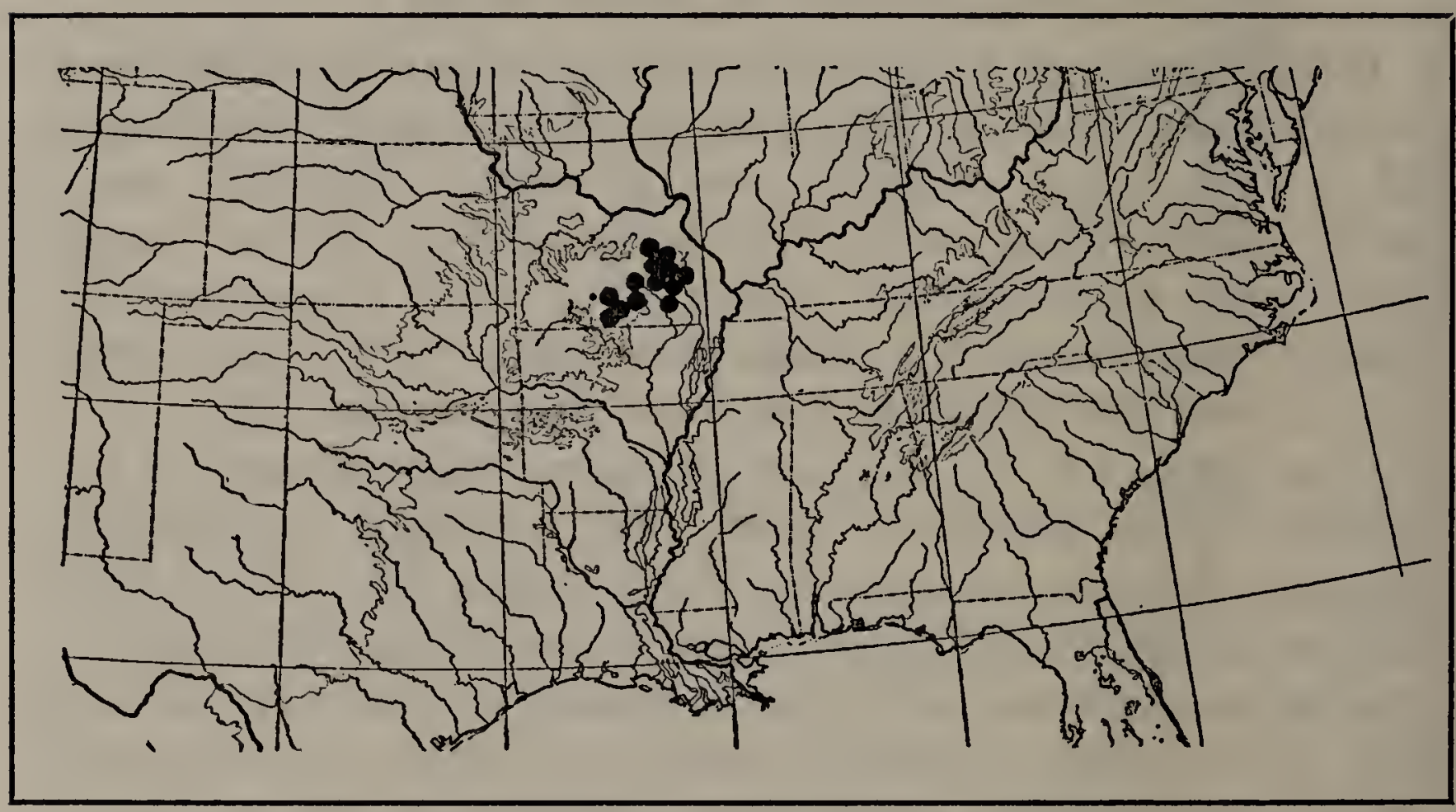

Map 13. Range of Tradescantia longipes.

connective broadly trapezoid; ovary ovoid, uniformly pubescent with glandular and eglandular hairs, sometimes almost glabrate; capsules obovoid-trigonal, $0.4-0.6 \mathrm{~cm}$. long; seeds roughly compressed-oblongoid, $0.2-0.3 \mathrm{~cm}$. long, the funicular scar linear, about as long as the seed.

Tradescantia brevicaulis Rafinesque according to Bush in Trans. Acad.

Sci. St. Louis, 14: 184 (1904) as to specimens cited, in part, not

Rafinesque.

Silicious and igneous hillsides, southeast-central Missouri. MAP 13.

Missouri: rich pockets of humus, rhyolitic hillsides at lower end of Lake Killarney, near Arcadia, Iron Co., May 3, 1933, Woodson E' Hubricht s.n. (ANSP,FM,G,MBG, TYPE, NY,US); same locality, May 8, 1925, Woodson 325 (MBG); rocky hills, Ironton, Iron Co., May 12, 1893, Eggert s.n. (FM,MBG,NY); woods, Grandin, Carter Co., May 6, 1905, Bush 2699 (G,MBG,US); exposed rocky banks, Gad's Hill, Wayne Co., April 25, 1898, Russell s.n. (MBG); sandy woods, Montier, Shannon Co., 
April 27, 1907, Bush 4350 (MBG); St. Francois River banks, near Silvermine, Madison Co., May 20, 1927, Larsen s.n. (MBG); Montauk State Park, Dent Co., May 13, 1933, McVeigh \& Kentner s.n. (Mo); dry porphyritic trachyte slopes, 3 miles east of Lesterville, Reynolds Co., May 13, 1934, Woodson Hubricht छீ Steyermark s.n. (MBG); wooded porphyritic trachyte slopes in "shut-in" along Cedar Creek, near Caledonia, Washington Co., May 13, 1934, Woodson Hubricht E๐ Steyermark s.n. (MBG); low cherty woods and slopes in County Hollow and along Eleven Point River, 5 mi. n.e. of Peace Valley, Howel Co., April 14, 1935, Steyermark 18626 (MBG); cherty upper slopes along Jacks Fork of Current River, $4 \mathrm{mi}$. s.e. of Arroll, Texas Co., April 13, 1935, Steyermark 18627 (MBG); Crawford Co., 11/2 mi. east of Steeleville, April 23, 1935, Shoop s.n. (MBG); rhyolitic hillsides between Doe Run and Iron Mountain, St. François Co., May 5, 1935, Woodson s.n. (MBG).

This beautiful little species apparently finds its closest affinities with $T$. Tharpii and $T$. hirsuticaulis, both of which have similar, petalaceous sepals. It differs from the former chiefly in the mixed glandular and eglandular pubescence of the pedicels, sepals, and ovary, and in the fact that the stem does not elongate appreciably in fruit, as in that species. From the latter relative it differs in its subacaulescent habit, laxly ascending bracts, and much longer pedicels, as outlined in the key to species.

As far as present records indicate, T. Tharpii is limited in Missouri to the limestone and chert prairies of the southwestern portion of the state (Green, Lawrence, and Jasper counties), while $T$. longipes is restricted to the interesting igneous-silicious plateau of the southeast-central (Washington, Crawford, Iron, Madison, Wayne, Carter, Dent, Reynolds, Howell, St. François, and Shannon counties). This species appears to be almost invariably associated with the extrusions of rhyolite, locally known as "porphyry," characteristic of the vicinity, and it has not been found by the writers elsewhere, although it evidently occurs upon the Roubidoux sandstone and Emminence chert as well. Upon several occasions this observation has been tested by deliberately locating horizons of rhyolite upon a state geological map and visiting them for the species, which was found with amusing regularity. Although intermediate stations in the seemingly distinct ranges of the two species are not known at present, it is scarcely improbable that they will be found. Tradescantia longipes is known to residents of the St. François Hills of southeast-central Missouri as "wild crocus."

Tradescantia longipes apparently hybridizes with $T$. canaliculata in the vicinity of Lake Killarney, Iron County, Missouri. 


\section{Tradescantia Reverchoni Bush}

(Plates I, fig. 4; V, fig. 14)

Roots rather stout and fleshy, densely ferruginous-tomentose; stems erect or ascending, straight or very slightly flexuose, simple, or branching infrequently, 3.0-10.5 dm. tall, densely arachnoid-villous, rarely glabrate; nodes 3-6; internodes $1-30$ $\mathrm{cm}$. long, the uppermost usually much abbreviated; leaves firmly membranaceous, deep green to somewhat subglaucous, the blade linear-lanceolate, long-acuminate, $10-35 \mathrm{~cm}$. long, $0.7-2.8 \mathrm{~cm}$. broad, arachnoid-villous, stomata somewhat more numerous upon the lower surface than upon the upper, the sheath 0.5-3.5 $\mathrm{cm}$. long, 0.9-3.0 cm. broad; cymes umbellate, few- to severalflowered, terminal, solitary, or infrequently accompanied by lateral, pedunculate inflorescences at the upper nodes; bracts foliaceous, somewhat saccate, widely divaricate, $2.5-7.0 \mathrm{~cm}$. long, $0.7-1.4 \mathrm{~cm}$. broad, arachnoid-villous as in the leaves; pedicels $1.5-2.3 \mathrm{~cm}$. long, pilose or villous, more or less reflexed and accrescent in fruit; sepals broadly elliptic, acute to acuminate, 0.9-1.2 cm. long, dull green, frequently somewhat suffused or edged with rose or purple, not inflated, pubescent with glandular and eglandular hairs interspersed; petals broadly ovate, 1.5-1.8 $\mathrm{cm}$. long, bright blue, rarely white; filaments abundantly pilose, connective broadly trapezoid; ovary ovoid, pubescent with glandular and eglandular hairs interspersed; capsules obovoidtrigonal, $0.6-0.8 \mathrm{~cm}$. long; seeds roughly compressed-oblongoid, $0.3-0.4 \mathrm{~cm}$. long, the funicular scar linear, about as long as the seed.

Tradescantia Reverchoni Bush in Trans. Acad. Sci. St. Louis, 14: 190 (1904).

Sandy soil, western Louisiana and eastern Texas. MAP 14.

Louisiana: sandy hillsides, Chopin, Natchitoches Parish, June 11, 1915, Palmer 7968 (MBG); Caddo Parish, date lacking, Dormon s.n. (MBG).

Texas: rocky woods, Lindale, June 9, 1902, Reverchon 2770 (MBG, TYPE); below McDade, May 29, 1923, Tharp 2186 (T,US); Dallas, date lacking, Reverchon s.n. (MBG,US); in an old convict grave-yard, vicinity of Huntsville, Walker Co., July 9-12, 1909, Dixon 328 (FM,NY); sands, Swan, June 3, 1903, Reverchon s.n. (MBG); near Houston, Harris Co., April 20, 1899, Eggert s.n. (MBG); sands, Sabine Pass, April 25, 1903, Reverchon s.n. (MBG); wet places, near Palestine, Anderson Co., June 8, 1899, Eggert s.n. (MBG); Henderson Co., May 21, 1931, Tharp s.n. (T); Nacogdoches Co., June 15, 1931, Whitehouse s.n. (T); Port O'Connor to Seadrift, March 29, 1930, Tharp s.n. (T). 
This species is one of the most conspicuous of the genus because of its size, and the character of its induments. The hairy roots, in particular, are noteworthy, and like those of no other known species, only being approached in quantity, but not in color and quality, by $T$. rosea var. ornata in Florida. It can scarcely be said that the dense, ferruginous indument of the roots is due to the sand in which they naturally grow, for plants cultivated in loam maintain it, and other species growing in similar sandy places, as T. canaliculata and T.occidentalis, are glabrate, or only irregularly and inconspicuously pilose.

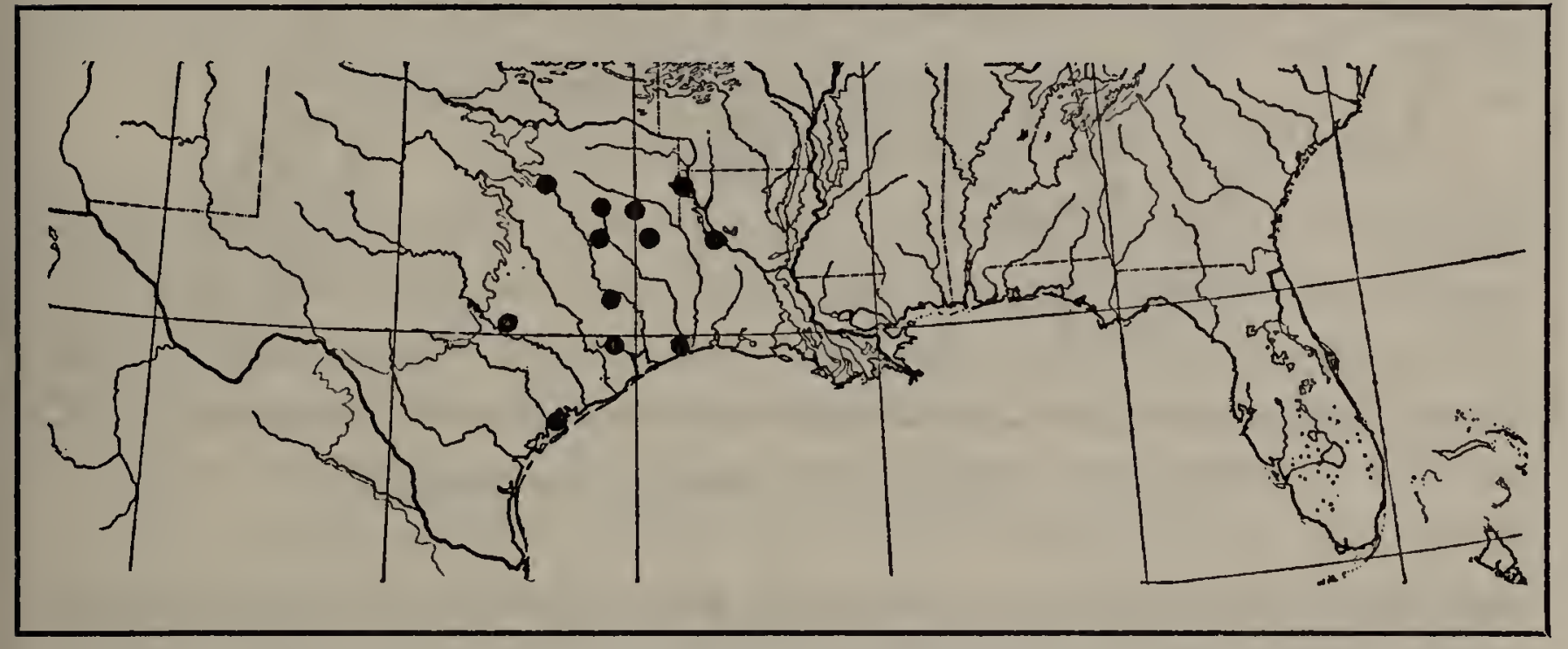

Map 14. Range of Tradescantia Reverchoni.

\section{Tradescantia humilis Rose}

(Plate V, fig. 18)

Roots stout and fleshy, usually somewhat short and tuberoid, at least in part, accompanied by more slender roots in varying quantity, irregularly pilose to glabrate; stems more or less diffuse and spreading, much branched, particularly at the base, $0.5-4.5$ $\mathrm{cm}$. long, densely and minutely puberulent or scabridulous to glabrate; nodes 2-7; internodes $3-12 \mathrm{~cm}$. long; leaves firmly membranaceous, deep green, or paler and somewhat subglaucous, minutely puberulent or scabridulous to glabrate the blade 11-20 $\mathrm{cm}$. long, 1.0-2.1 cm. broad, rather stiff and somewhat recurved or falcate, margins usually more or less crisped and tinged with rose or purple, stomata somewhat more numerous upon the lower surface than upon the upper, the sheath $0.5-1.5 \mathrm{~cm}$. long, 1.2-2.2 $\mathrm{cm}$. broad; cymes umbellate, few- to many-flowered, terminal, solitary, or more frequently accompanied by lateral pedunculate inflorescences at the upper nodes; bracts foliaceous, more or less 
recurved and crisped as in the leaves, minutely puberulent or scabridulous to glabrate, $3-15 \mathrm{~cm}$. long, $0.4-1.5 \mathrm{~cm}$. broad; pedicels $1.5-2.5 \mathrm{~cm}$. long, mixed-puberulent or -pilose, sharply spreading and slightly accrescent in fruit; sepals broadly elliptic, acute to acuminate, dull green, occasionally somewhat edged or suffused with purple, $0.9-1.1 \mathrm{~cm}$. long, pubescent with glandular and eglandular hairs interspersed; petals broadly ovate, 1.1-1.9

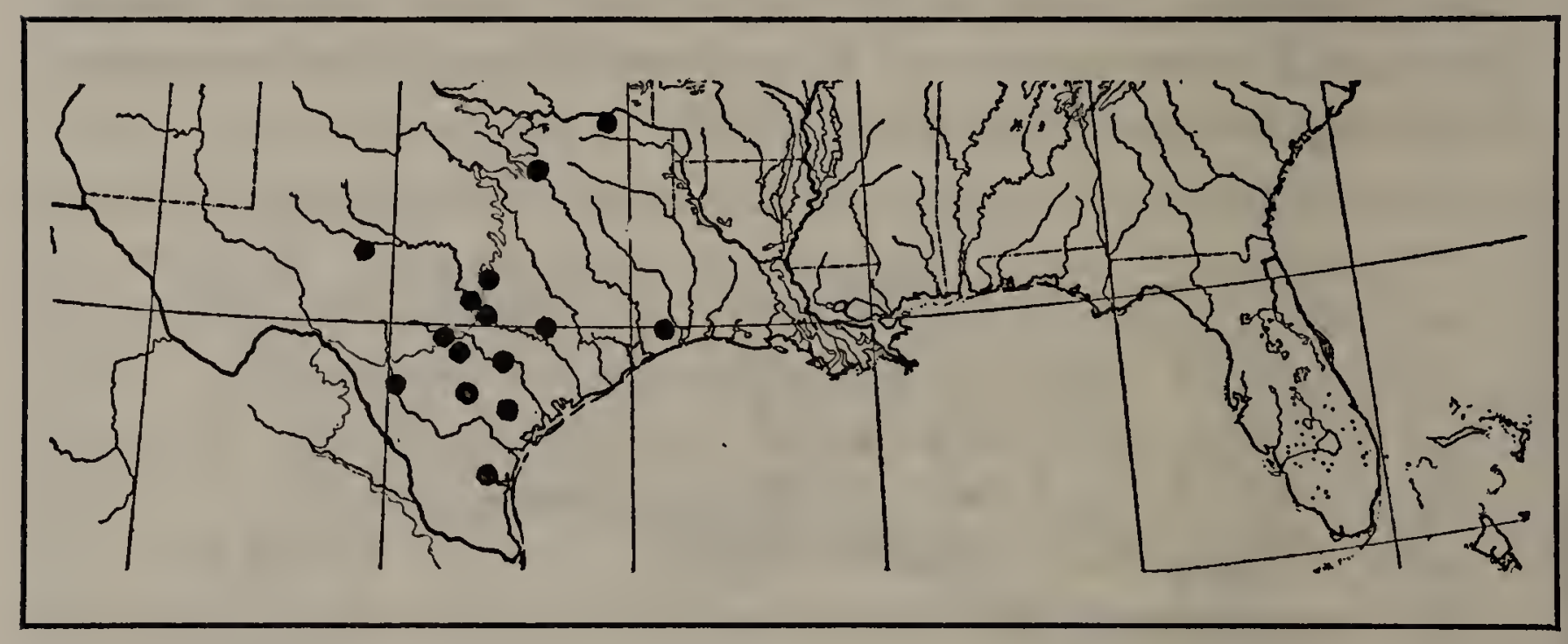

Map 15. Range of Tradescantia humilis.

$\mathrm{cm}$. long, bright blue, occasionally pink; ovary ovoid, pubescent with glandular and eglandular hairs as on the sepals, rarely glabrate; capsules obovoid-oblongoid, $0.6-0.7 \mathrm{~cm}$. long; seeds roughly compressed-oblongoid, $0.2-0.3 \mathrm{~cm}$. long, the funicular scar linear, about as ong as the seed.

Tradescantia humilis Rose in Contrib. U.S. Nat. Herb. 5: 204 (1899). Bush in Trans. Acad. Sci. St. Louis, 14: 192 (1904). - Small, Fl. Southeast. U.S. 239 (1903).

Tradescantia Virginica L. $\gamma$ Drummondii C. B. Clark in DC. Monogr. 3: 291 (1881).

Tradescantia intermedia Bush, loc. cit. 191 (1904).

Sandy and rocky soil, east-central and southern Texas.

MAP 15.

Texas: Industry, 1895, Wurzlow s.n. (US, TYPE); west of the Brazos, April, 1839, Lindheimer s.n. (MBG); rocky prairies, San Antonio, March 18, 1903, Reverchon 4055 (MBG); near Belknap, April 20, 1858, Hayes s.n. (FM); sandy soil in woods, Dallas, May 23, 1903, Bebb 1375 (FM); between Kerrville and San Antonio, April 23, 1931, Jones 18576 (MBG); uplands, calcareous soil, Cedar Park, Williamson Co., April 18, 1928, Palmer 33396 (MBG); sandy prairies, near Goliad, Goliad Co., April 9, 1900, Eggert s.n. (MBG); along R.R. tracks, Austin, May 8, 1915, Young 72 (MBG); shaded ledges, sandstone hills, Campbelton, Atascosa Co., 
March 9, 1917, Palmer 11233 (G,MBG); sandy soil, San Angelo, May 20, 1903, Reverchon 4053a (G,MBG); fine deep sand, Carrizo Springs, Dimmit Co., May 4, 1928, Palmer 33751 (MBG,NY); Gonzales Co., March 27, 1927, Bogusch 905 (US); exact date and locality lacking, Drummond 429 (G); Bastrop, April, 1928, Duval s.n. (T); Goose Creek, Spring, 1928, Tharp s.n. (T); prairie, Paris, April 23, 1927, McMullen s.n. (T); New Braunfels, alt. 750 ft., April, 1903, Pilsbry s.n. (ANSP).

A familiar plant of the eastern half of Texas, where it is commonly known as "grass violet." Because of its wide range and frequency, it appears to hybridize with other species. In spite of occasional intergradations, however, it is one of the most characteristic of the genus in the United States.

\section{Tradescantia subacaulis Bush}

(Plates I, fig. 3; V, fig. 11)

Roots stout and fleshy, usually somewhat short and tuberoid toward the distal end and there more or less ferruginous-tomentose, smaller, more slender roots also present in varying quantity; stems more or less diffuse and spreading, much branched, particularly at the base, 1-3 dm. long, densely arachnoid-villous, rarely nearly glabrate; nodes $1-3$; internodes $2-11 \mathrm{~cm}$. long; leaves firmly membranaceous, deep green, more or less arachnoidvillous as on the stems, the blade linear-lanceolate, long-acuminate, $10-18 \mathrm{~cm}$. long, $0.5-1.5 \mathrm{~cm}$. broad, relatively lax and flaccid, stomata somewhat more numerous upon the ower surface than upon the upper, the sheath $0.4-0.8 \mathrm{~cm}$. long, 0.9-1.4 $\mathrm{cm}$. broad; cymes umbellate, few- to several-flowered, terminal, solitary, or accompanied by lateral, pedunculate inflorescences at the upper nodes; bracts foliaceous, rather lax and flaccid as the leaves, arachnoid-villous, 3-11 cm. long, 0.7-2.0 cm. broad; pedicels $2-3 \mathrm{~cm}$. long, mixed-puberulent or -pilose, sharply spreading and somewhat accrescent in fruit; sepals broadly elliptic, acute to acuminate, $0.7-0.8 \mathrm{~cm}$. long, dull green, or occasionally somewhat petalaceous and more or less suffused with rose or purple, pubescent with glandular and eglandular hairs interspersed; petals broadly ovate, $1.3-1.4 \mathrm{~cm}$. long, bright blue; ovary ovoid, pubescent with glandular and eglandular hairs interspersed; capsules obovoid-trigonal, $0.5-0.6 \mathrm{~cm}$. long; seeds roughly compressed-oblongoid, $0.2-0.3 \mathrm{~cm}$. long, the funicular scar linear, about as long as the seed.

Tradescantia subacaulis Bush in Trans. Acad. Sci. St. Louis, 14: 185 (1904).

Tradescantia Texana Bush, loc. cit. 192 (1904).

Tradescantia Harbisoni Bush in Rep. Mo. Bot. Gard. 16: 100 (1905). 
Sandy soil, southeast-central Texas.

MAP 16.

TExas: Dawson, Navarro Co., April 16, 1903, Reverchon 4054 (MBG, TYPE); Austin, Travis Co., May 18, 1872, Hall 669 (FM,G,MBG,US); Bryan Brazos Co., April 11, 1903, Harbison 200 (MBG,US); Fentress, Caldwell Co., March 29, 1931, Mercer 22 (T); Pt. O'Connor, March 29, 1930, Tharp s.n. (T); Lee Co., Jan. 17, 1931, Knobloch s.n. (T); Smithville, May 12, 1930, Marrs s.n. (T); Bastrop, April 6, 1929, Tharp 5658 (T,US); Travis Co., April 6, 1924, Tharp 2879 (T); sand-hills, Caldwell Co., March 6, 1931, McBryde s.n. (T).

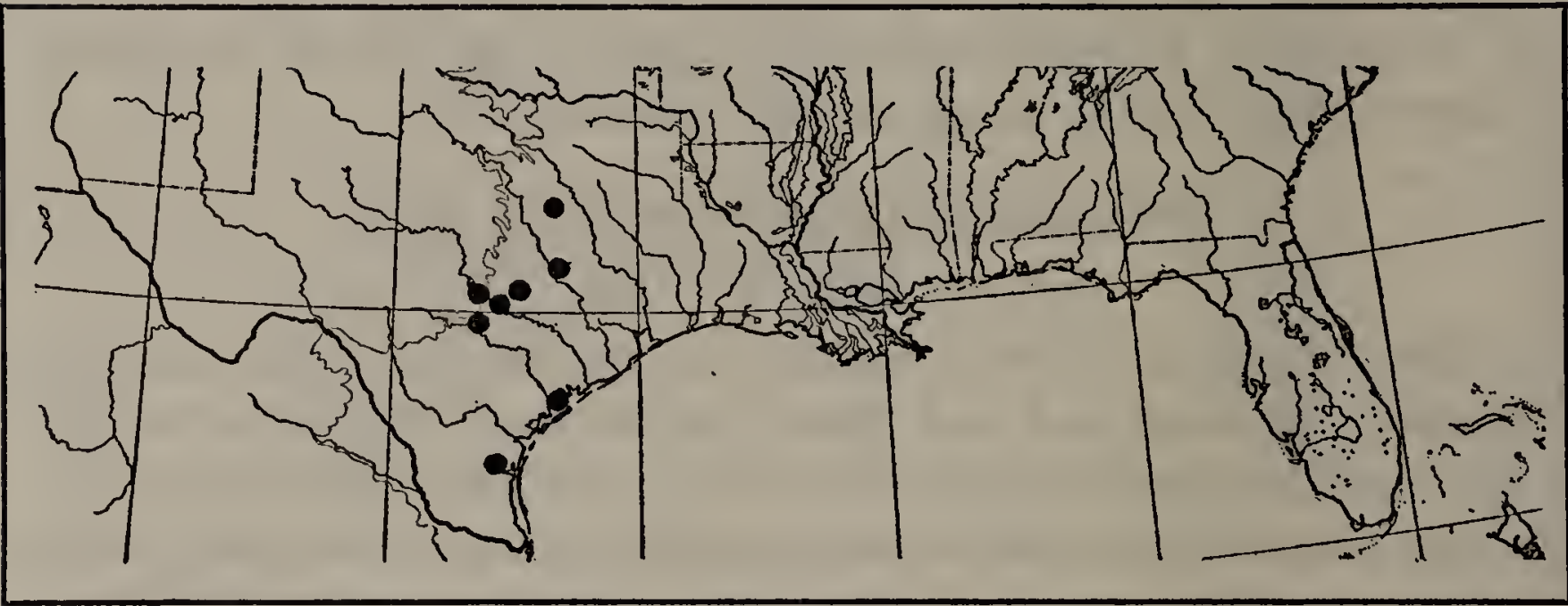

Map 16. Range of Tradescantia subacaulis.

Closely related to $T$. humilis, but differing in its appressed, arachnoid villosity, and more flaccid foliage. The tuberoid roots of this species are very interesting, being rather inverse-napiform to obfusiform in shape, slightly more fleshy at the distal ends, and there usually capped with an area of matted, brownish, persistent hairs. As in T. humilis, T. Reverchoni, and T. occidentalis, more slender, nearly fibrous, roots are interspersed among the fleshy. The flowers of $T$. subacaulis are very fragrant, recalling the perfume of violets.

\section{Tradescantia roseolens Small}

(Plates V, fig. 16; VI, fig. 3)

Roots relatively slender, only slightly fleshy, inconspicuously and irregularly pilose to glabrate; stems erect or ascending, straight, not flexuose, or only slightly so, $1.9-4.2 \mathrm{~cm}$. long, densely puberulent to pilose, infrequently glabrate or glabrous; nodes 2-6; internodes $2-21 \mathrm{~cm}$. long; leaves membranaceous, glaucous or subglaucous, densely puberulent or pilosulose, infrequently glabrate, the blade linear-lanceolate, long-acuminate, 
11 $-42 \mathrm{~cm}$. long, $0.5-1.6 \mathrm{~cm}$. broad, stomata about equally distributed upon the upper and the lower surface, the sheath 0.4 $1.5 \mathrm{~cm}$. long, $0.9-2.0 \mathrm{~cm}$. broad; cymes umbellate, few- to manyflowered, terminal, solitary, or not infrequently also lateral and pedunculate at the upper nodes; bracts foliaceous, $2-15 \mathrm{~cm}$. long, $0.5-1.5 \mathrm{~cm}$. broad, widely spreading or divaricate, puberulent as in the leaves, or rarely glabrate; pedicels $1.2-2.5 \mathrm{~cm}$. long, densely glandular-puberulent, reflexed and somewhat accrescent in fruit; sepals elliptic, acute to acuminate, $0.8-1.1 \mathrm{~cm}$. long,

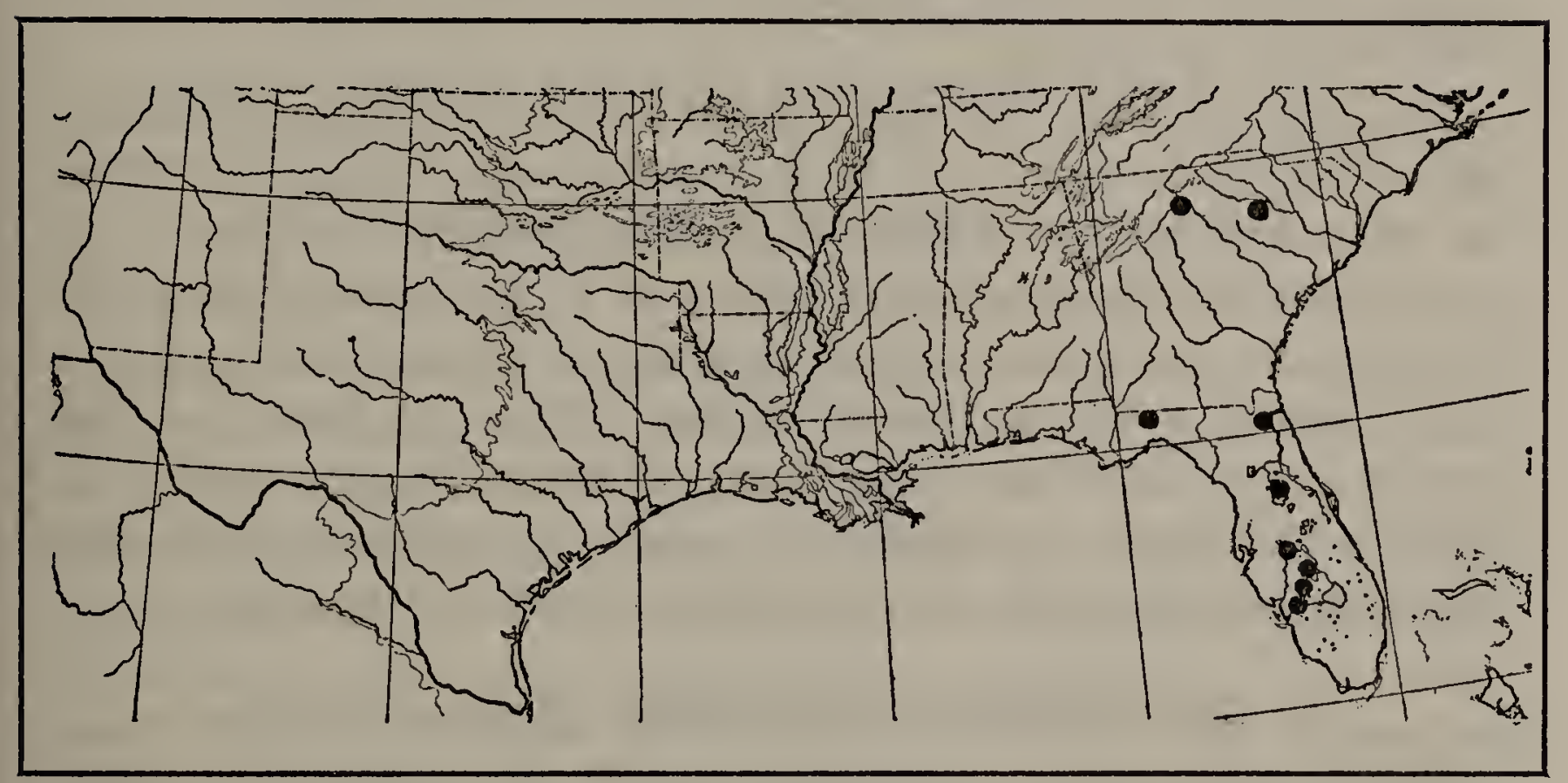

Map 17. Range of Tradescantia roseolens.

densely glandular-puberulent, glaucous, frequently edged or suffused with purplish-rose; petals broadly ovate, $1.2-1.4 \mathrm{~cm}$. long, deep blue, infrequently magenta; filaments abundantly pilose, connective broadly trapezoid; ovary ovoid uniformly glandular-puberulent; capsules obovoid-oblongoid, $0.5-0.7 \mathrm{~cm}$. long; seeds roughly compressed-oblongoid, $0.3-0.4 \mathrm{~cm}$. long, the funicular scar linear, about as long as the seed.

Tradescantia roseolens Small in Bull. Torrey Bot. Club, 51: 379 (1924).

Tradescantia longifolia Small in Bull. Torrey Bot. Club, 24: 233 (1897);

Fl. Southeast. U.S. 240 (1903) nec Mociño \& Sessé, nec Greenman.

Deep sand, inland peninsular Florida. Also known from one locality each in south-central South Carolina and southern Georgia.

MAP 17.

South Carolina: open woods, sandy soil, near Irmo, Lexington Co., April 19, 1932, Palmer 39963 (MBG).

Georgia: dry sand-clay bank, 7 miles south of Royston, Franklin Co., Aug. 19, 1927, Wiegand छ Manning 715 (C). 
Florida: sandhills e. of Sebring, May 1, 1919, Small \& De Winkeler 9083 (NY); ancient sand-dunes, s. of Avon Park, May 23, 1921, Small s.n. (NY,TYPE); ancient sand-dunes, n. of Kuhlman, April 25, 1921, Small छ De Winkeler 9962 (NY); common, dry soil, Polk Co., April 21, 1894, Ohlinger 47 (FM); in sand barrens east of Brighton, De Soto Co., May 30, 1930, Bright 4061 (D); dry sandy soil, high pine land, vicinity of Eustis, Lake Co., Aug. 1-15, 1894, Nash 1574 (MBG,NY); dry pine barrens, Winter Haven, June, 1900, Curtiss 6667 (ANSP,MBG,NY); dry thickets, Duval Co., June, year lacking, Curtiss 2996 (ANSP,MBG,NY); low open woods, near Jacksonville, May 29, 1896, Curtiss 5672 (FM,MBG,NY); pine barrens, near Jacksonville, April 3, 1894, Curtiss 4680 (MBG,NY); ancient sand dunes, Lake Jackson, April 15, 1923, Small Mosier छ० De Winkeler 10871 (NY).

Dr. Small reports that this species has a pronounced odor like that of tea-roses which can be detected at some distance. When the stem and leaves of this species are glabrate, the plants can scarcely be distinguished from plants of $T$. occidentalis, save that the glaucous bloom of the former is not as pronounced as in the latter species. The indument of the stem and leaves of this species is apparently as variable in quality and quantity as in $T$. hirsutiflora, purely glandular or purely eglandular pubescence occurring, or glandular and eglandular hairs interspersed.

\section{Tradescantia occidentalis (Britton) Smyth}

Roots rather stout and fleshy, usually accompanied by more slender, fibrous roots in varying quantity, inconspicuously and irregularly pilose to glabrate; stems erect or ascending, straight, more or less branching, $0.5-6.1 \mathrm{~cm}$. tall, glabrous, glaucous and somewhat subsucculent; nodes 2-6; internodes $1-25 \mathrm{~cm}$. long; leaves firmly membranaceous, glaucous, entirely glabrous, the blade linear-lanceolate, long-acuminate, $5-50 \mathrm{~cm}$. long, $0.2-2.0$ $\mathrm{cm}$. broad, stiff and widely divaricate or falcate, stomata about equally distributed upon the lower and upper surfaces, the sheath rather turgid and inflated, $0.4-3.0 \mathrm{~cm}$. long, $0.4-3.5 \mathrm{~cm}$. broad; cymes umbellate, few- to many-flowered, terminal, solitary, usually accompanied by one or more lateral, pedunculate inflorescences at the upper nodes; bracts foliaceous, glabrous, glaucous, sharply reflexed or divaricate, $1.5-21.0 \mathrm{~cm}$. long, 0.4 $2.0 \mathrm{~cm}$. broad; pedicels $1-2 \mathrm{~cm}$. long, glandular-puberulent, rarely glabrate or glabrous, reflexed and somewhat accrescent in fruit; sepals elliptic, acute to acuminate, $0.4-1.0 \mathrm{~cm}$. long, glaucous, or somewhat suffused with rose or.purple, uniformly glandular-puberulent, rarely glabrate or glabrous, very rarely 
with a terminal barb of weak, eglandular hairs in hybrid specimens; petals broadly ovate, $0.7-1.6 \mathrm{~cm}$. long, bright blue to rose and magenta; filaments abundantly pilose, connective broadly trapezoid; ovary ovoid, glandular-puberulent, very rarely glabrate or glabrous; capsules oblongoid-trigonal, $0.4-0.7 \mathrm{~cm}$. long; seeds roughly compressed-oblongoid, $0.2-0.4 \mathrm{~cm}$. long, the funicular scar linear, about as long as the seed.

Sepals and pedicels more or less uniformly glandular-puberulent, rarely approaching glabrate; Minnesota to Texas, and westward to Montana, Arizona, and southern Utah ............................var. typica.

Sepals and pedicels absolutely glabrous apparently limited to Arizona . . ........................ var. scopulorum

18a. Tradescantia occidentalis var. typica.

(Plates III, fig. 3; V, fig. 19; VI, fig. 10; VII, fig. 8)

Stems $0.5-6.1 \mathrm{dm}$. tall, usually rather stout; nodes $3-6$; internodes $1-25 \mathrm{~cm}$. long; leaf-blade $6-50 \mathrm{~cm}$. long, $0.2-2.0 \mathrm{~cm}$. broad, leaf-sheath $0.5-3.0 \mathrm{~cm}$. long, $0.8-3.5 \mathrm{~cm}$. broad; cymes few- to many-flowered; bracts $1.5-21.0 \mathrm{~cm}$. long, $0.4-2.0 \mathrm{~cm}$. broad; pedicels $1.2-2.1 \mathrm{~cm}$. long, more or less densely glandularpuberulent, rarely approaching glabrate; sepals $0.4-1.0 \mathrm{~cm}$. long, more or less densely glandular-puberulent, rarely nearly glabrate, very rarely with a few, weak, eglandular hairs interspersed at the tip in hybrid colonies; petals $1.2-1.6 \mathrm{~cm}$. long, bright blue to rose or magenta.

Tradescantia occidentalis (Britton) Smyth in Trans. Kans. Acad. Sci. 16: 163 (1899). - Bush in Trans. Acad. Sci. St. Louis, 14: 186 (1904) as T. occidentalis Britton. - Britton, Man. 241 (1901) as T. occidentalis Britton. - Robinson \& Fernald, in Gray, Man. ed. 7, 265 (1908). - Britton \& Brown, Ill. Fl. ed. 2, 1: 461 (1913). - Small, Fl. Southeast. U.S. 239 (1903), as T. occidentalis Britton.-Rydberg, Fl. Rocky Mts. ed. 2, 145 (1922); Fl. Prairies \& Plains, 199 (1932).

Tradescantia elata Loddiges, Bot. Cab. 1513 (1829) [?].

Tradescantia Virginiana L. var. occidentalis Britton, in Britton \& Brown, Ill. Fl. ed. 1. 1: 377 (1896).

Tradescantia Laramiensis Goodding in Bot. Gaz. 33: 68 (1902). Rydberg, Fl. Rocky Mts. ed. 2, 145 (1922) as T. larimiensis.

Tradescantia vaginata Bush, loc. cit. 189 (1904).

Tradescantia difforme Bush in Rep. Mo. Bot. Gard. 16: 101 (1904).

Tradescantia universitatis Cockerell in Nature, 75: 7 (1906). - Rydberg,

Fl. Rocky Mts. ed. 2, 145 (1922); Fl. Prairies \& Plains, 199 (1932).

Tradescantia ramifera Lunell in Am. Midl. Nat. 2: 124 (1911).

Tradescantia ramifera Lunell var. Chandonnetii Lunell, loc. cit. 159 (1912). 
Prairies and plains, mostly frequenting rather sandy soil, North Dakota to Texas, and westward to central Montana, Arizona, and southern Utah; also found on the local prairies of southern Minnesota and central Arkansas; rare in localities of western Wisconsin.

MAP 18.

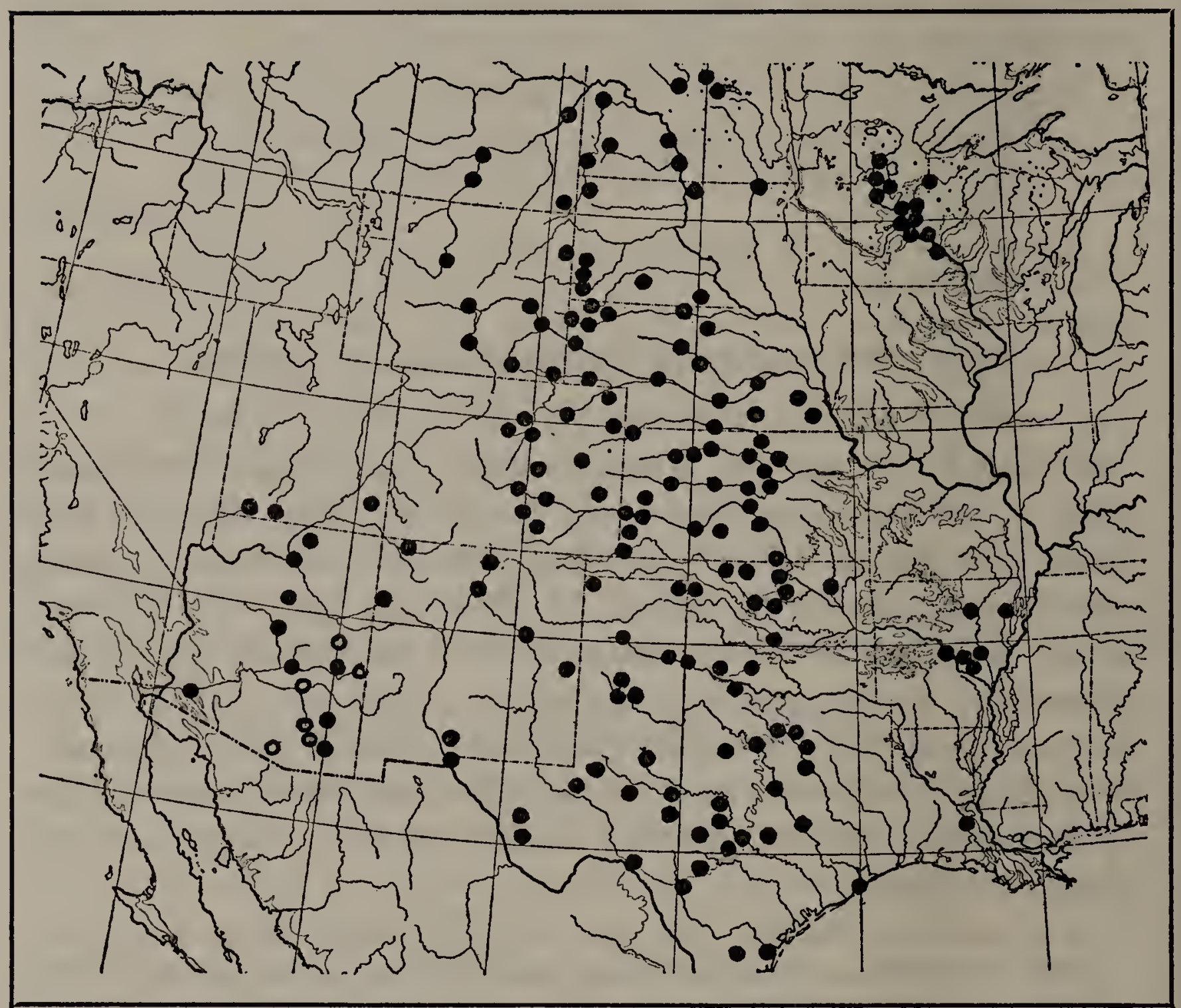

Map 18. Range of Tradescantia occidentalis var. typica ( $)$ and var. SCOPULORUM $(\mathrm{O})$.

Wisconsin: wooded sand scarp along brook, Pepin, Pepin Co., Aug. 27, 1927, Fassett 5110 (Mich.,UW); Danbury, Aug. 29, 1916, Baird s.n. (UW); sand terrace, Prescott, Pierce Co., Aug. 4, 1934, Fassett 16062 (MBG,UW).

Minnesota: sandy soils, Little Falls, June 17, 1910, Chandonnet s.n. (D); Ft. Snelling, June 19, 1891, Mearns s.n. (US); Lake Vadnais, Ramsey Co., Oct. 15, 1926, Rydberg s.n. (NY); St. Cloud, date lacking, Campbell s.n. (O); sandy gravel slope, along Miss. River, at Brainerd, July 9, 1918, Rosendahl E๐ Butters 3613 (UM); Center City, Chisago Co., July, 1892, Taylor 1424 (UM); sand blowout, so. Anoka Co., July 12, 1914, Butters Rosendahl छ Weiss 2812 (UM); on dry sandy slope, deep ravine at Pine Bend, Dakota Co., Sept. 19, 1928, Rosendahl 5749 (UM); Milaca, July, 1892, Sheldon 3087 (UM); dry dunes, sand prairie, Weaver, Wabash Co., Aug. 23, 1926, Fassett छे Hotchkiss 3303 (UW). 
Arkansas: flat prairies near Mesa, Prairie Co., May 22, 1924, Palmer 25067 (MBG); low sandy prairies, near Beebe, White Co., with T. canaliculata, with which it obviously hybridizes, May 3, 1933, Woodson छ Hubricht s.n. (MBG); Stuttgart, May 12, 1910, Howell 647 (US); common along R.R. 1/2 mi. N. of Waldenburg, Poinsett Co., April 30, 1935, Hubricht s.n. (MBG); Lonoke Co., April 20, 1921, Buchholz s.n. (Ark.); deserted field, Broadway and W. 24th St., Little Rock Polaski Co., April 27, 1935, Lodewyks 162 (MBG).

Louisiana: Opelousas, April, 1880, Langlois s.n. (NY).

North Dakota: sand hills, Rugby Junct., July 27, 1896, Rider 341 (FM); Mandan, 1915, Sarvis 61 (US); Dickinson, July 23, 1908, Holgate s.n. (US); in deep gravel on rolling prairie, Pleasant Lake, Benson Co., July 3-28, 1912, Lunell s.n. (D,MBG); sandy soil, Cannon Ball, June 28, 1912, Bergman 1851 (MBG); sand hills, McHenry Co., July 13, 1899, Lunell s.n. (G,UM); Little Missouri valley, 14 miles from Watford City, on grassy terrace between the buttes, July 2, 1927, Lakela 456 (UM); in talus, foot of bluff, Marmarth, June 7, 1914, Moyer 479 (UM).

South Dakota: Rapid City, July 22, 1912, Visher 1566 (NY); Hecla, July, 1925, Moore 402 (UM); sand hills, Mound City, June, 1925, Moore 404 (UM); sandy banks, Hot Springs, Fall River Co., June 10, 1914, Over 2662 (US); flood-plain, Keya Paha River, Tripp Co., July 9, 1924, Over 15904 (US); sand hills, Antelope Creek, July 26, 1896, Wallace 23 (NY); Valley, Harding Co., July 20, 1920, Over s.n. (US); Washabaugh, date lacking, Visher 2303 (NY); Custer, Aug. 22, 1908, Petersen s.n. (LSU).

Nebraska: Hershey, June 1, 1903, Mell 76 (NY,US); on Middle Loup River, near Thedford, Thomas Co., on sand hills, June 18, 1893, Rydberg 1380 (NY,US); Valentine, May 27, 1889, Bates 467 (NY); near Hay Springs, June 6-7, 1901, MacDougal 48 (NY); meadow, Scott's Bluff Co., Aug. 22, 1901, Baker s.n. (MBG); rich soil, prairie lowland, near Lincoln, June 10, 1900, Hedgcock s.n. (MBG); Anselmo, July 6, 1889, Webber s.n. (MBG); low grounds, Bloomington, June, 1891, Morrow s.n. (MBG); Minden, June 7, 1929, Hapeman s.n. (MBG); common, sandy prairies, Sioux Co., June-July, 1927, Kramer 180 (MBG); gravelly prairies, by stream, west of Sydney, Cheyenne Co., June 30, 1921, Wiegand 450 (C); Pine Ridge, Dawes Co., date lacking, Webber 4871 (UN); Long Pine, Brown Co., May, 1890, Bates s.n. (UN); Box Butte Co., July 6, 1892, Smith E Pound 221 (UN); Kearney, Buffalo Co., Aug., 1893, Smith छ Lee 7684 (UN); Central City, June 10, 1901, Thornber 10 (UN); Sterling, June 16, 1925, Jones s.n. (PC); Edgar, June 11, 1909, Clemens s.n. (PC).

Kansas: vicinity of South Haven, along the road, 4 miles west of town, July 4, 1929, Rydberg छ Imler 560 (MBG,NY); Haviland, 1904, Frame s.n. (US); on hillsides and slopes, especially on "gumbo," soil, Bloom Tp., Clay Co., May 14, 1906, Schaffner s.n. (OSU); Sheridan Co., 1931, Weber 179 (KSAC); Lincoln Co., July, 1895, Hitchcock s.n. (KSAC); Ellsworth Co., July, 1895, Hitchcock s.n. (KSAC); Cheyenne Co., June 28, 1897, Hitchcock s.n. (KSAC); Turon, Reno Co., July, 1892, Hitchcock s.n. 
(KSAC); Wichita Co., July 30, 1895, Hitchcock s.n. (KSAC); Stanton Co., Aug. 6, 1895, Hitchcock s.n. (KSAC); Ellis Co., July, 1895, Hitchcock s.n. (KSAC); a prairie herb along a road east of Lyons, Rice Co., May 29, 1928, Gates 15141 (KSAC); moist prairie, Gove Co., July 7, 1918, Ikenberry s.n. (KSAC); Rockport, Rooks Co., May 27, 1889, Bartholomew s.n. (KSAC); Courtland, Republic Co., June 26, 1892, Hitchcock s.n. (KSAC); Hamilton Co., Aug., 1895, Hitchcock s.n. (KSAC); Beloit, Mitchell Co., June 18, 1897, Hitchcock s.n. (KSAC); Morton Co., Aug., 1895, Hitchcock s.n. (KSAC); Graham Co., June 20, 1897, Hitchcock s.n. (KSAC); Kearney Co., May 17, 1898, Clothier s.n. (KSAC); Bucklin, Ford Co., July, 1892, Hitchcock s.n. (KSAC); dry sand bank eight miles northeast of Salina, May 19, 1921.

Oklahoma: Tonkawa, May 26, 1908, Mahoney 113 (FM); sandy loam, Frederick, July 5, 1903, Duncan 92 (MBG); Norman, June 4, 1915, Emig 435 (MBG,US); Huntsville, Kingfisher Co., May 6, 1896, Blankinship s.n. (MBG,US); Catoose, May 8, 1895, Bush 1264 (MBG,US); vicinity of Fort Sill, May 30, 1916, Clemens 11523 (MBG); Turkey Creek, S. of Buffalo Pasture, Wichita Forest, May 24, 1923, Rose 42883 (US); prairie, near A'va, Woods Co., May 23, 1913, Stevens 619 (NY,US); sandy valley, near Shattuck, Ellis Co., May 20, 1914, Clifton 3150 (NY); Ingersoll, May 7, 1902, Canby, Sargent छ Bush 123 (G); Guthrie, Logan Co., June 10, 1914, Stevens 3222 (G); Stillwater, June 12, 1896, Morris s.n. (OSU).

Texas: Cherokee, San Saba Co., April 19, 1931, Norton 14 (T); gravelly soil, Austin, date acking, Tharp 1256 (T,US); Canyon, Randall Có., June 7, 1931, Neelly s.n. (T); Whicita Falls, April 20, 1926, McKee s.n. (T); Childress Co., June, 1929, Tharp 20 (T); common in dry stony soil, Llano, May 13, 1899, Bray s.n. (T); Midland, May 9, 1902, Tracy 8046 (NY,T,US); Carbon, Eastland Co., April 28, 1930, Collector Unknown (T); Mertzon, Irion Co., April, 1932, White 5 (T); Lee Co., April 18, 1930, Woods s.n. (T); Ft. McKavett, Schleicher Co., May 1, 1931, Jones 32 (T); Uvalde Co., April 20, 1931, Tharp s.n. (T); gravelly ground, thickets, along Limpia Creek, near Ft. Davis, Jeff Davis Co., June 11, 1928, Palmer 34484 (MBG,NY); sands, Dallas, June 6, 1901, Reverchon 2482 (MBG,NY); Devil's River, Valverde Co., May, 1913, Orcutt 6072 (MBG); sandy soil, Brazos Co., April, 1903, Harbison 14791 (MBG,NY); sands, Corsicana, April 25, 1902, Reverchon s.n. (MBG); Palo Duro Canyon, May 30, 1902, Reverchon 2769 (MBG,NY,US); Waco, date lacking, Pace s.n. (MBG); sandy soil, San Angelo, May 20, 1903, Reverchon 4053 (MBG); valley land, Amarillo Creek, June 29, 1902, Reverchon s.n. (MBG); sands, Estelline, May 25, 1904, Reverchon 4280 (MBG,US); San Antonio, Bexar Co., April 19, 1911, Clemens $छ$ Clemens s.n. (MBG); prairies, near Granbury, (May 5, 1900, Eggert s.n. (MBG); near Lubbock, 1930, Demaree 7614 (MBG); prairies, near Colorado, Mitchell Co., June 9, 1900, Eggert s.n. (MBG); on rocks, at Canutillo, El Paso Co., July 12, 1911, Barlow s.n. (FM); in sandy field, Lake Worth, Tarrant Co., April 14, 1919, Ruth 705 (MBG,US); Robstown, April 13, 1905, Williamson s.n. (ANSP); roadside, Petersburg, May 10, 1930, Reid छ Demaree 7641 (US); Lipscomb, Lipscomb Co., July 1, 1903, Howell 24 (US); Brantley's tract, Monahan's, 
Ward Co., alt. 790 m., May 15, 1917, Clawson 13919 (US); Crabapple, Gillespie Co., date lacking, Jermy 344 (US); prairie above Marfa, Sept., 1883, Havard 80 (US); vicinity of Terrell, Kaufman Co., May 13, 1904, Tyler s.n. (US); Galveston, March 17, 1925, Tharp 3340 (US); Silver Falls, Crosbyton, May 14, 1926, Studhalter 1180 (US); San Diego Co., May, 1895, Nealley s.n. (US); San Marcos, Summer, 1897, Stanfield s.n. (NY); Dalhart, June 24, 1920, Jones 235 (G).

Montana: Custer, June 3, 1890, Blankinship 57 (MBG,US); Glendive, 1907, Butler 5012 (NY); Big Horn River, July, 1891, Tweedy s.n. (NY); Sioux Nat. Forest, Carter Co., May 28, 1917, Larson s.n. (NYSM).

Wyoming: Hartville, July 20, 1894, Nelson 492 (US); Fairbanks, July 14, 1894, Nelson 492 (MBG,NY); Platte River, near Ferris, July 19, 1898, Nelson 4904 (MBG,NY); rolling hills, Edgemont Road, 20 mi. s.w. Hot Springs, July 30, 1927, Hayward 2525 (RM); sandy ridges, Douglas, July $12,1901, N$ elson 8383 (RM); sandy river banks, Torrington, Laramie Co., June 28, 1901, Nelson 8293 (MBG,NY,US); Alcova, Natrona Co., hot, white sands, July 1, 1901, Goodding 175 (FM,G,MBG,NY,US); Newcastle, Weston Co., alt. $4319 \mathrm{ft}$. , date lacking, Pammell 168 (MBG); in moist rocky canyons, Halleck Canyon, Albany Co., July 4? 1900, Nelson 7455 (MBG,NY,US); Cambria Canyon, July 29, 1896, Nelson 2521 (US); Morse, June 15, 1912, Cary 745 (US).

Colorado: Custer Co., 1889, Cockerell s.n. (FM); prairie, alt. 5300 ft., Denver, July 1, 1917, Clokey 2817 (US); Colorado Springs, alt. 6000 ft., July-Aug., 1912, Brumback ש Davies 17 (FM); New Windsor, July 4, 1895, Osterhout s.n. (US); Wray, Yuma Co., alt. 1100 m., July 1-4, 1919, Eggleston 15194 (US); sandy soil, White Rock, 8 mi. east of Boulder, Boulder Co., June 5, 1913, Vestal s.n. (MBG); Canyon City, 1871, Brandegee 70 (MBG); Ft. Morgan, Morgan Co., June 23, 1896, Pammell 300 (MBG); along highway west of Fleming, June 19, 1929, Mathias 329 (MBG); Ft. Collins, alt. 5000 ft., July 10, 1897, Crandall 2480 (FM, MBG,NY,US); Eads, June 19, 1898, Baker Earle E' Tracy 1126 (MBG, NY); Hugo, June 11, 1906, Marsh s.n. (US); Walsenburg, alt. 1800 m., June 5, 1900, Rydberg छ Vreeland 6449 (NY); Baculite Mesa, 6 mi. n. e. of Pueblo, June 7, 1915, Pennell 5751 (NY); Central City, Gilpin Co., 1869, Scovell s.n. (Mich.).

New Mexico: Santa Fe, Sept. 4, 1929, Whitehouse s.n. (T); on sandy dunes, $5 \mathrm{mi}$. NE of Portales, alt. $3600 \mathrm{ft}$., June 14, 1930, Goodman $\boldsymbol{\xi}^{3}$ Hitchcock 1117 (MBG,NY); Organ Mts., alt. 4500 ft., Dona Ana Co., Sept. 1, 1897, Wooton 543 (MBG,US); Caliente, July 19, 1898, Earle s.n. (MBG,NY); elevated rocky region $12 \mathrm{mi}$. west of Vegas, Aug. 14, 1847, Fendler 862 (MBG); Ojo Caliente, Aug. 7, 1894, Smith s.n. (ANSP); Aztec, July 1, 1895, Griffin s.n. (US); vicinity of Santa Rosa, alt. 1400 m., Sept. 4, 1926, Arséne छ Benedict 17655 (US); Gallup, June 23, 1897, Herrick 817 (US); Agua Azule, July, 1874, Rothrock 118 (G).

Arizona: Oak Creek, June 23, 1883, Rusby s.n. (G,NY,US); Aztec, June 6, 1899, Diehl s.n. (PC); Johnson, June 20, 1890, Jones s.n. (PC); Moki Reservation and Little Colorado River, Aug. 1-Sept. 5, 1897, Hough 9 (US); Ft. Apache, 89 miles south of Holbrook, July 10, 1901, 
Hough 114 (NY,US); Flagstaff, July, 1891, MacDougal s.n. (US); 10 miles south of Navajo Spring, July 25, 1892, Wooton s.n. (US); Ft. Verde, Aug., 1887, Mearns 251 (NY); Roosevelt Dam, Gila Co., April 30, 1922, Wiegand E Upton 3029 (C); Fort Grant, July 16, 1917, Munz s.n. (C); Laguno Canyon, Painted Desert, July 10-11, 1920, Clute 11 (MBG,NY, US); Cornville, May 26, 1922, Jones s.n. (UC).

UTAн: Allen Canyon, southwest of Abajo Mts., alt. 1800-2000 m., July 30-31, 1911, Rydberg $छ$ Garrett 9314 (NY,US); Johnson, alt. 5000 ft., May 23, 1894, Jones 5289w (US); Zion Canyon, July 22, 1920, Garrett 2962 (NY); Silver Reef, May 3, 1894, Jones 5153 (MBG).

\section{8b. Tradescantia occidentalis var. scopulorum (Rose)} comb. nov.

Stems $14-35 \mathrm{~cm}$. tall, usually somewhat more slender than in the typical variety; nodes $2-5$; internodes $1-10 \mathrm{~cm}$. long; leafblade $5-45 \mathrm{~cm}$. long, $0.4-0.9 \mathrm{~cm}$. broad, leaf-sheath $0.4-3.0 \mathrm{~cm}$. long, $0.4-3.1 \mathrm{~cm}$. broad; cymes few- to several-flowered; bracts 4-15 cm. long, $0.8-0.9 \mathrm{~cm}$. broad; pedicels $1-2 \mathrm{~cm}$. long, glabrous; sepals $0.5-0.8 \mathrm{~cm}$. long, glabrous; petals $0.7-1.0 \mathrm{~cm}$. long, bright blue.

Tradescantia scopulorum Rose in Contrib. U.S. Nat. Herb. 5: 205 (1899) in part as to the type. - Bush in Trans. Acad. Sci. St. Louis, 14: 188 (1904); Rydberg, Fl. Rocky Mts. ed. 2, 145 (1922).

Moist canyons and stream-banks, Arizona.

MAP 18.

Arizona: by streams of the Santa Catalina Mts., alt. 2500-3500 ft., May 16, 1881, Pringle s.n. (FM,G,MBG,US,TYPE); Snowflake, Aug. 4, 1897, Zuck, s.n. (FM,MBG,NY,US); Oracle, alt. $5600 \mathrm{ft}$., Aug. 28, 1903, Jones s.n. (MBG,US); Camp Grant, alt. 4750 ft., July, 1874, Rothrock 372 (FM); "The Basin," Santa Catalina Mts., Aug. 5, 1916, Harris C16469 (US); Devil's Canyon, Oct. 10, 1926, Peebles Harrison छ Kearney 3177 (US); Canyon of the Blue River near Casper's Ranch, 15 miles below Blue P.O., Graham Co., June 14, 1905, Hough s.n. (US); Baboquivari Canyon, Aug. 15, 1926, Peebles Harrison छ Kearney 2794 (US); Pinal Mts., July 30, 1892, Toumey 439 (US); Bowie, Sept. 21, 1884, Jones s.n. (PC).

Variety scopulorum is not recognized as a proper species since its complete glabrism is apparently its only distinguishing character. Moreover, intergradations to the glandular induments of pedicels and sepals of var. typica are encountered in large numbers. It is maintained as a variety only because completely glabrous individuals appear to be confined to the extreme southwestern range of the species in Arizona. In the tendency toward glabrism of $T$. occidentalis var. typica, the pedicels and the very base of the sepals appear to be more conservative of the indument 
than are the tips of the sepals, and it is frequently possible to detect only a very few, glandular hairs upon the place of attachment of the sepals to the pedicel upon an otherwise absolutely glabrous specimen.

The relationship of the habitally very similar $T$. canaliculata to $T$. occidentalis var. typica in the regions where the distributions of the two species coincide is very interesting, for they appear to hybridize quite readily in nature. On the Grand Prairie of east-central Arkansas, the junior author was able to observe the effects of obvious hybridization of $T$. canaliculata and $T$. occidentalis var. typica at first hand. In this colony, as in other similar swarms of hybridizing species of Tradescantia, notably $T$. virginiana and $T$. canaliculata, superficially typical individuals of either species are difficult to find, and must be searched for in particular. The intermediate individuals, however, in the case of $T$. canaliculala and $T$. occidentalis are exceedingly numerous, and are easily detected by a tuft of weak, eglandular hairs at the tips of the otherwise uniformly glandular-puberulent sepals. Such individuals are easily interpreted by comparison with typical plants of $T$. canaliculata having eglandular-barbate sepals.

After having compared numerous, interrupted colonies for a distance of many miles in central Arkansas another observation may be offered. In the largest swarm colony visited, typical individuals of both $T$. canaliculata and $T$. occidentalis could be detected. The intermediate, however, were far in the majority. In smaller colonies, on the other hand, apparently only intermediates were present, and one might suppose the population to represent a distinct species in the absence of experience with the larger colonies. It might be guessed from this observation that the hybrid clones, through their greater vigor, are able to survive the parent clones of the proper species, eventually losing all direct evidence of their origin.

Such observations upon the behavior of $T$. canaliculata and $T$. occidentalis var. typica in central Arkansas, has admittedly had much weight in the relegation to synonymy of $T$. vaginata and $T$. difforme, both of which have glandular-puberulent sepals tufted with a few, weak, eglandular hairs in the familiar fashion. The type specimens of both are otherwise quite as in $T$. occidentalis var. typica. It is furthermore a fact that in the eastern half of Texas, where both species are common, absolutely typical, 
uniformly glandular specimens of the latter are actually the exception, and eglandular-barbate individuals similar to the supposed hybrids of central Arkansas, in the majority. The case has been discussed in detail on pages 37 to 38 .

The status of $T$. elata Lodd. must be left in a rather unsatisfactory state. From the colored plate published in the 'Botanical Cabinet' for 1829 , it is not quite possible to identify the plant in question, reported evasively as from "western United States," from among $T$. occidentalis, $T$. canaliculata, and $T$. bracteata. The first has been chosen provisionally to receive it under synonymy.

\section{Tradescantia Wrightii Rose \& Bush}

\section{(Plate VII, fig. 3)}

Roots relatively slender, somewhat fleshy, irregularly and inconspicuously pilose to glabrate; stems erect or ascending, straight, simple, $0.8-1.8 \mathrm{~cm}$. tall, glabrous, glaucous or glaucescent, somewhat subsucculent; nodes 1-3; internodes $1-15 \mathrm{~cm}$. long; leaves firmly membranaceous or somewhat subsucculent, glabrous, glaucous or glaucescent, the blade linear-lanceolate, long-acuminate, $4-10 \mathrm{~cm}$. long, $0.2-0.5 \mathrm{~cm}$. broad, spreading or ascending, stomata about equally distributed upon the lower and upper surfaces, the sheath $1-2 \mathrm{~cm}$. long, $0.4-1.0 \mathrm{~cm}$. broad; cymes umbellate, few- to several-flowered, terminal, solitary; bracts foliaceous, glabrous, glaucous or glaucescent, spreading or ascending, $1-7 \mathrm{~cm}$. long, $0.3-0.6 \mathrm{~cm}$. broad; pedicels $1.2-1.7$ $\mathrm{cm}$. long, glabrous, or rarely with a very few glandular hairs, reflexed and somewhat accrescent in fruit; sepals elliptic, acute to acuminate, $0.5-0.6 \mathrm{~cm}$. long, glaucous or glaucescent, glabrous, or rarely with a few glandular hairs at the base; petals broadly ovate, about $1 \mathrm{~cm}$. long, rose to magenta and purple; filaments abundantly pilose, connective broadly trapezoid; ovary ovoid, glabrous, or rarely with a very few glandular hairs at the base of the style; capsules obovoid-trigonal, $0.3-0.4 \mathrm{~cm}$. long; seeds broadly compressed-oblongoid to oblongoid-trigonal, $0.2-0.25 \mathrm{~cm}$. long, the funicular scar linear, much shorter than the seed.

Tradescantia Wrightii Rose \& Bush in Bush in Trans. Acad. Sci. St. Louis, 14: 188 (1904). 


\section{Tradescantia pinetorum Greene}

(Plates I, fig. 2; V, fig. 12; VI, fig. 2; VII, fig. 2)

Roots slender and fibrous, glabrate, or very inconspicuously and irregularly puberulent, bearing occasional, napiform-fusiform tubers $1-3 \mathrm{~cm}$. long, and $0.5-1.0 \mathrm{~cm}$. in diameter; stems erect or ascending, straight, or slightly flexuose branching rather infrequently, 0.8-3.9 dm. tall, minutely scabridulous, very rarely glabrate, glaucous and somewhat subsucculent; nodes 1-6; internodes 2-10 cm. long; leaves firmly membranaceous, glaucous, the blade linear-lanceolate, long-acuminate, $1-10 \mathrm{~cm}$. long, $0.15-0.8 \mathrm{~cm}$. broad, ascending to somewhat falcate, glabrous, or essentially so, stomata about equally distributed upon the lower and upper surfaces, the sheath $0.3-1.0 \mathrm{~cm}$. long, 0.4 $1.4 \mathrm{~cm}$. broad, minutely scabridulous to glabrate above; cymes umbellate, few- to several-flowered, terminal, solitary, or more frequently accompanied by 1-3 lateral inflorescences at the upper nodes, the uppermost sessile or subsessile, and the successively lower with increasingly evident peduncles; bracts foliaceous, $0.3-6.0 \mathrm{~cm}$. long, widely divaricate or reflexed, glabrous, glaucous, pedicels $0.8-1.0 \mathrm{~cm}$. long, minutely glandular-puberulent, somewhat reflexed and accrescent in fruit; sepals elliptic, acute to acuminate, $0.4-0.6 \mathrm{~cm}$. long, delicately membranaceous, glaucous, frequently more or less suffused with rose, minutely glandular-puberulent; petals ovate, $0.9-1.2 \mathrm{~cm}$. long, bright blue to rose and purple; filaments abundantly pilose, connective trapezoid; ovary minutely glandular-puberulent; capsules obovoid-trigonal, $0.3-0.4 \mathrm{~cm}$. long; seeds roughly compressed-oblongoid, $0.15-0.2 \mathrm{~cm}$. long, the funicular scar linear, much shorter than the seed.

Tradescantia pinetorum Greene in Erythea, 1:247. 1893; Wooton \&

Standley in Contrib. U.S. Nat. Herb. 19: 126 (1915). - Brückner in

Engler \& Prantl, Nat. Pflanzenfam. 15a: 166 (1930).

Tradescantia tuberosa Greene in Bot. Gaz. 6: 185 (1881), non Roxb.

Moist canyons and stream-banks, extreme southwestern New Mexico and adjacent Arizona.

MAP 20.

New Mexico: East Canyon, Grant Co., Aug. 27-Sept. 12, 1911, Holzinger s.n. (MBG,US); vicinity of Cloudcroft, Otero Co., Aug. 8, 1899, Wooton s.n. (US); along Apache Creek, valley of the Tularosa River, Catron Co., Aug. 25, 1905, Hough s.n. (US); Gila Hot Springs, Aug.21, 1900, Wooton s.n. (US); sandy places, Mogollon Mts., Catron Co., Aug. 1881, Rusby 414 (G,MBG,NY,US); Pinos Altos Mts., Aug. 23, 1880 , Greene s.n. (MBG, ISOTYPE); Ft. Wingate, 1887, Mathews 24 (G). 
Arizona: Rincon Mts., alt. 7500 ft., 1891, Nealley 151 (US); Stone Cabin Canyon, Sept. 19, year lacking, Thornber छ Griffiths 184 (UA); about rocks, Wilgus Ranch, Chiricahua Mts., alt. 5600 ft., Aug. 31, 1907, Blumer U104 (US); moist sheltered places, Miller Peak, Huachuca Mts., alt. 10000 ft., Aug. 22, 1907, Goodding 2405 (MBG); rocky slopes, Ramsey Canyon, Huachuca Mts., Aug. 22, 1918, Goodding 733 (G,NY); Soldiers' Camp, Santa Catalina Mts., Aug. 7, 1908, Livingston Eे Thornber s.n. (UA).

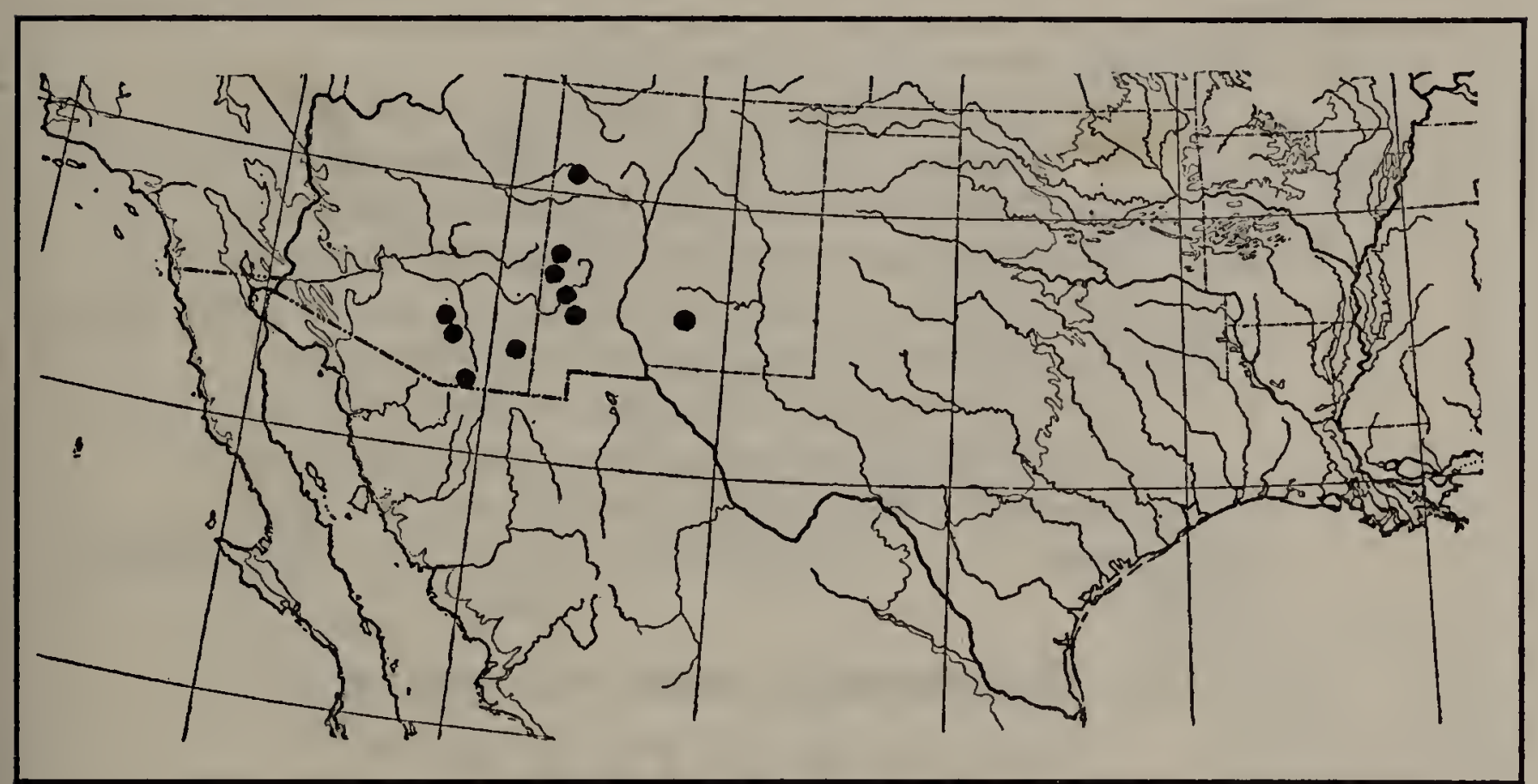

Map 20. Range of Tradescantia pinetorum.

One of the most characteristic and constant species of the genus. As has already been explained, $T$. pinetorum and $T$. Wrightii appear to constitute a minor sub-group in the genus on the basis of similarity of the seeds.

\section{Tradescantia rosea Ventenat}

Roots slender and fibrous, yellowish gray, glabrate to very conspicuously and persistently lanate; stems erect or ascending, straight or more or less flexuose, simple or branching rather frequently slender and rather weak, pale green or yellowish green; leaves membranaceous, pale green, the blade linear to linearlanceolate, spreading or rather laxly ascending, acuminate, stomata essentially restricted to the lower surface, glabrous, or occasional somewhat pilosulose toward the base; cymes fewto several-flowered, terminal, solitary, or accompanied by lateral, pedunculate inflorescences at the upper nodes; bracts extremely inconspicuous, much smaller than the foliage leaves, scarious or only slightly foliaceous; pedicels glabrous, $0.8-1.5 \mathrm{~cm}$. long, 
somewhat accrescent in fruit; sepals elliptic, acute to acuminate, $0.4-0.6 \mathrm{~cm}$. long, pale green, glabrous; petals ovate, bright rose or pink; filaments laxly pilose, connective trapezoid; ovary glabrous; capsules obovoid- to subglobose-trigonal; seeds roughly compressed-spherical, $0.15-0.2 \mathrm{~cm}$. long, the funicular scar punctiform.

Leaf-blade about as broad as the sheath or somewhat broader............................ typica.

Leaf-blade much narrower than the sheath.

Plants not caespitose, or scarcely so; stems simple or branching infrequently; inflorescence usually held well above the foliage; bracts essentially scarious, scarcely distinguishable; roots more or less persistently lanate.......... var ornata

Plants caespitose; stems usually much branched; inflorescence usually equalled or somewhat surpassed by the folliage; bracts clearly manifest, somewhat foliaceous; roots glabrous or glabrate .......................... graminea

\section{1a. Tradescantia rosea var. typica.}

(Plates V, fig. 15; VII, fig. 4)

Roots irregularly puberulent to glabrate; stems branching rather frequently, $2.5-4.0 \mathrm{dm}$. tall, pale green, glabrous, or very inconspicuously and sparsely pilosulose; nodes $2-4$; internodes 3-15 cm. long; leaf blade linear-lanceolate, $12-20 \mathrm{~cm}$. long, $0.4-1.4 \mathrm{~cm}$. broad; leaf sheath $0.2-1.2 \mathrm{~cm}$. long, $0.4-1.2 \mathrm{~cm}$. broad, more or less inflated, laxly pilose or pilosulose to glabrate; bracts extremely reduced, $0.1-0.3 \mathrm{~cm}$. long, scarious, or only slightly foliaceous, ascending; pedicels $0.8-1.2 \mathrm{~cm}$. long; petals $0.7-0.9 \mathrm{~cm}$. long; ovary obovoid; capsules obovoid-trigonal, $0.2-0.25 \mathrm{~cm}$. long.

Tradescantia rosea Ventenat, Jard. Cels. pl. 24 (1800). - Britton, Man. ed. 2, 241 (1905). - Robinson \& Fernald in Gray, Man. ed. 7, 264 (1908). - Britton \& Brown, Ill. Fl. 1: 378 (1897). - Brückner in Engler \& Prantl, Nat. Pflanzenfam. 15a: 167 (1930).

Tradescantia graminifolia Rafinesque Atl. Jour. 1: 148 (1832).

Tradescantia rosea Vent. var. pauciflora Rafinesque, New Fl. 2: 88 (1836).

Cuthberthia rosea (Vent.) Small, FI. Southeast. U.S. 237 (1903).

Sandy soil, coastal North Carolina to northeastern Florida.

MAP 21. 
21b. Tradescantia rosea var. ornata (Small), comb. nov.

(Plates I, fig. 1; V, fig. 17)

Roots more or less persistently and conspicuously whitelanate; stems simple, or branching infrequently, not caespitose, or scarcely so, $2.0-4.7 \mathrm{dm}$. tall, pale green, glabrous, or essentially so; nodes $3-4$; internodes $5-18 \mathrm{~cm}$. long; leaf blade linear, 2-26 cm. long, $0.1-0.4 \mathrm{~cm}$. broad; leaf sheath $0.3-2.0 \mathrm{~cm}$. long, $0.3-1.2 \mathrm{~cm}$. broad, more or less inflated, laxly pilose or pilosulose to glabrate; bracts extremely reduced, scarcely distinguishable from the bracteoles, $0.1-0.2 \mathrm{~cm}$. long; pedicels $1.0-1.5 \mathrm{~cm}$. long; petals ovate, the margins somewhat erose or fringed, $0.9-1.3$ $\mathrm{cm}$. long; ovary obovoid; capsules obovoid-trigonal, $0.3-0.35$ $\mathrm{cm}$. long.

Cuthbertia ornata Small, Man. Southeast. Fl. 259 (1933).

Sandy "scrub," Florida.

MAP 21.

Florida: in dry sandy pineland, Fort Myers, Lee Co., April 8, 1930, Moldenke 899 (MBG,NY); Mullock Creek district, about 8 miles southeast of Fort Myers, Lee Co., May-June, 1917, Standley 431 (FM,MBG,US); common, Tampa, Aug. 1, 1898, Ferguson s.n. (MBG); Tampa, May, 1876, Garber s.n. (FM,NY,US); pine barrens, Dunedin, April 14, 1900, Tracy, 6755 (FM,MBG,US); pine clearing near bay, near St. Petersburg, April 15, 1908, Deam 4065 (D,MBG,US); dry sandy soil, Orange City, May 5, 1910, Hood s.n. (MBG); pinelands, St. Leo, April 23, 1927, O'Neil s.n. (MBG); in low sandy woods, Lake Helen, April 28, 1906, Deam s.n. (MBG); low pinelands, Merritt's Island, Jan. 8, 1923, Small, Small E De Winkeler 10784 (NY); low pinelands, Ft. Lauderdale to Miami, Febr., 1911, Small Carter \& Small 3387 (NY); Kissimmee, Osceola Co., May 7, 1901, Mearns s.n. (US); Clarcona, Orange Co., Jan. 2, 1900, Meislahn 146a (US); Sebring, April 26, 1923, Howell 1076 (US); Melbourne Beach, July 14, 1896, Hopkins s.n. (US); Fort Meade, Polk Co., March, 1880, Smith s.n. (US); pine barrens, St. Augustine, June-Aug., 1875, Reynolds s.n. (FM); dry ground, Polk Co., April 12, 1894, Ohlinger 1401 (FM); Gainesville, March, 1876, Garber s.n. (FM).

21c. Tradescantia rosea var. graminea (Small), comb. nov. (Plates I, fig. 5; V, fig. 13)

Roots glabrate or glabrous, rarely very slightly and irregularly puberulent; stems much branched, caespitose, $0.4-3.9 \mathrm{~cm}$. tall, pale yellowish green, glabrous above, irregularly pilose or pilosulose below; nodes 3-6; internodes 1-12 $\mathrm{cm}$. long; leaf blade linear, 5-16 cm. long, $0.1-0.5 \mathrm{~cm}$. broad; leaf sheath $0.3-1.0 \mathrm{~cm}$. long, $0.3-1.0 \mathrm{~cm}$. broad, more or less inflated, laxly pilose or 
pilosulose to glabrate; bracts clearly manifest, somewhat foliaceous, $0.2-0.7 \mathrm{~cm}$. long; pedicels $1.2-1.5 \mathrm{~cm}$. long; petals $0.8-1.0$ $\mathrm{cm}$. long; ovary subglobose; capsules subglobose-trigonal, $0.2-0.3$ $\mathrm{cm}$. long.

Cuthbertia graminea Small, Fl. Southeast. U. S. 237 (1903); ed. 2, 237 (1913). - Britton \& Brown, Ill. Fl. ed. 2, 1: 459 (1913).

Sandy "hammocks", coastal North Carolina to Florida.

MAP 21.

North Carolina: near Wilmington, May, 1867, Canby 8475 (FM,G,MBG,US); sandy soil near Southern Pines, May 13, 1904, Biltmore 14928 a (G,MBG,NY,US); Hamlet, May, 1897, Ashe s.n. (NY); coastal plain at White Lake, in sand, Bladen Co., July 16, 1926, Heller 14093 (MBG); dry sandy soil, open scrubland, Kinston, July 9, 1922, Randolph छ Randolph 559 (C,G); sandy bank, west of Laurel Hill, Scotland Co., July 3, 1927, Wiegand छे Manning 720 (C); Red Springs, Oct. 16, 1932, Vardell s.n. (NC).

South Carolina: woods, outskirts of Columbia, Lexington Co., April 27, 1932, Weatherby 6116 (G,NY); sandy woods, near Graniteville, Aiken Co., May 21, 1899, Eggert s.n. (MBG); near Big Cedar Creek, Chesterfield Co., June 26, 1895, Ward s.n. (NY); Orangeburg, April, 1911, Huger 19 (MBG); Kershaw Co., May, 1895, Huger s.n. (NY); Lancaster Co., near Kershaw, July 26, 1906, House, 2591 (MBG,NY,US); low sandy flats near Black Creek Pond, Hartsville, July 28, 1920, Norton s.n. (US); sandy oak and pine woods, Nichols, Marion Co., July 7, 1927, Wiegand छั Manning $721(\mathrm{C}, \mathrm{G})$.

Georgia: in open scrub woods, sand hills, Augusta, April 30, 1902, Cuthbert 667 (NY); dry pine barrens, near Graymont, Emanuel Co., June 6, 1901, Harper 817 (MBG,NY,US); about Augusta, Richmond Co., June 27-July 1, 1895, Small s.n. (NY,TYPE); dry sand hills along Big Lot's Creek, Bulloch Co., June 17, 1901, Harper 913 (G,NY,US).

Florida: St. Nicholas, Duval Co., July 16, 1896, Lighthipe s.n. (NY); Lake Alfred, July 11, 1922, Armstrong \& Armstrong s.n. (MBG); Levy Co., June-July, 1898, Hitchcock 1939 (FM,MBG); high pine land, vicinity of Eustis, Lake Co., June 15, 1894, Nash 879 (FM,MBG,NY,US); high pineland near Apopka, April 25, 1930, Blanton s.n. (MBG); dry sandy soil, Palatka, June 24, 1910, Hood s.n. (MBG); Hibernia, March, 1869, Canby s.n. (US); pinelands, Hawthorne, May 3, 1925, O'Neil 570 (US); Lake Astachula, Sumter Co., March, 1879, Smith s.n. (US); Sanford, July 20, 1894, Bitting 49 (FM); Bradentown, May, 1924, Wheeler s.n. (FM); Marco, July-Aug., 1900, Hitchcock s.n. (FM).

This pretty variety appears to be worthy of cultivation. It is low-growing, with clean, attractive foliage, and bright rose or pink flowers in close umbels. Taxonomically, it is distinctive because of its narrow leaves, nearly glabrous roots, and somewhat foliaceous bracts, indicating a transition from Cuthbertia 
to such species of Tradescantia as the southwestern $T$. Wrightii and $T$. pinetorum.

Although an old species, and of a striking and peculiar element of the genus, $T$. rosea has long been credited with a very mistaken geographical distribution. The seventh edition of Gray's Manual gives the range of the species as "Md. to Fla., w. to Mo. and 'Tex.'", an evident repetition of similarly erroneous citations contained in several of the older manuals and floras.

\section{Tradescantia micrantha Torrey}

(Plate VI, fig. 11)

Roots slender and fibrous, glabrate or very minutely puberulent; stems creeping or trailing, branching rather frequently, rooting at the nodes, at least in part, somewhat fleshy and subsucculent, 0.3-3.0 dm. long, glabrous, nodes 3-10; internodes $0.5-5.0 \mathrm{~cm}$. long; leaves somewhat subsucculent, deep green, the blade oblong-elliptic, acute to acuminate, $1.0-3.5 \mathrm{~cm}$. long, $0.3-0.8 \mathrm{~cm}$. broad, sharply spreading, or slightly falcate, margins ciliolate, otherwise glabrous or essentially so, stomata restricted to the lower surface, the sheath $0.2-0.4 \mathrm{~cm}$. long, $0.2-0.5$ $\mathrm{cm}$. broad, papery, more or less pilosulose or scabridulous; cymes umbellate, few- to several-flowered, terminal, solitary; bracts foliaceous, similar to the leaves, $0.9-1.7 \mathrm{~cm}$. long, $0.4-0.7$ $\mathrm{cm}$. broad; pedicels $0.8-1.2 \mathrm{~cm}$. long, very slender, glabrous or essentially so, spreading and slightly accrescent in fruit; sepals ovate-lanceolate, acuminate, $0.4-0.5 \mathrm{~cm}$. long, hyaline, keeled minutely scabridulous; petals ovate, $0.5-0.7 \mathrm{~cm}$. long, bright rose or pink; ovary ovoid, glabrous; filaments rather sparsely pilose, connective trapezoid; capsules and seeds unknown.

Tradescantia micrantha Torrey in Bot. Mex. Bound. 224 (1859). Bush in Trans. Acad. Sci. St. Louis, 14: 193 (1904). - Small, Fl. Southeast. U.S. 240 (1903).

Moist soil, southeastern coastal Texas. MAP 22.

Texas: Rio Hondo, Cameron Co., Sept., 1913, Chandler 7061 (US); mud near windmill, King's Ranch, Kleburg Co., May 8, 1919, Schulz 63 (US); Brownsville, Oct. 2, 1924, Runyon 677 (US); along Corpus Christi Bay, Nueces Co., alt. sea level to $40 \mathrm{ft.}$, April 9-12, 1894, Heller 1564 (NY,US); Green Island, June 23-29, 1922, Tharp 1134 (T,US); sandy oak woods, west of San Antonio Bay, Sept. 7, 1929, Tharp s.n. (T); at edge of mesquite woods, 8 miles west of Mission, Hidalgo Co., July 21, 1932, Clover 176 (MBG). 
This species makes a curious and rather pretty plant for cultivation in hanging baskets in greenhouses. It easily propagates itself vegetatively which is perhaps an explanation of its failure to set seed. No fruit has been discovered upon the specimens examined. It may be that individual clones cover large areas and that seeds are only produced in those occasional spots where two or more clones are growing together. Tradescantia micrantha

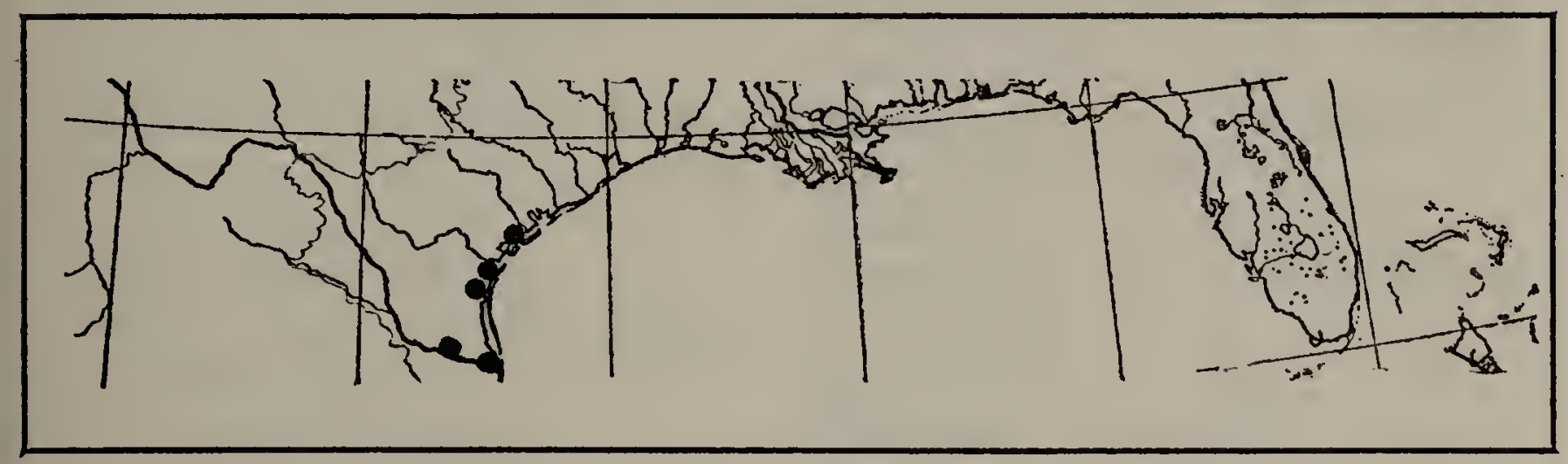

Map 22. Range of Tradescantia micrantha.

is apparently most closely related to $T$. brachyphylla Greene, of northeastern Mexico. The seeds of $T$. brachyphylla are compressed-subspherical with a prominent pit and a linear funicular scar about as long as the seed.

\section{EXCLUDED SPECIES}

Callisia cordifolia (Sw.) Anderson \& Woodson, comb. nov.

Tradescantia cordifolia Swartz, Prodr. Veg. Ind. Occ. 57 (1783); Fl.

Ind. Occ. 1: 601 (1797). - Brückner in Engler \& Prantl, Nat.

Pflanzenfam. 15a: 167 (1930).

Leiandra cordifolia (Sw.) Rafinesque Fl. Tell. 2:16.18-.

Tradescantia Floridana S. Watson in Proc. Amer. Acad. 17: 381 (1882).

Tradescantella Floridana (S. Wats.) Small, Fl. Southeast. U.S. 238 (1903); ed. 2, 238 (1913).

The genus Callisia is a transitional group between the Hexandrae and Triandrae of the Commelinaceae-Tradescantieae, having one to six stamens, bi- or trilocular ovary, and regular flowers. The natural affinity of $C$. cordifolia with Callisia will appear obvious to anyone who has tried to distinguish it from C. umbellulata Lam. of the Antilles and adjacent Central and South America. The habit of the two species is closely similar, and it would appear almost impossible to distinguish sterile specimens. The shape, venation, and texture of the foliage, and also its relation to the stem, is almost identical. In both species 
the foliage becomes sharply reduced toward the inflorescence. The small white flowers of $C$. umbellulata are only somewhat smaller than in $C$. cordifolia, and the structure of the stamens is essentially alike. Furthermore the seeds of $C$. cordifolia are similar to those of other species of Callisia, and differ notably from seeds of known species of Tradescantia, being very small $(0.1 \mathrm{~cm}$. or somewhat less in diameter), with a peculiar punctiform funicular scar subtended by an inconspicuous, decurrent ridge. 


\section{LIST OF EXSICCATAE}

The distribution numbers are printed in italics. Unnumbered collections are indicated as s.n. (sine numero). The numbers in parentheses are the species numbers used in this treatment.

Ainslie, G. G. s.n. (5); s.n. (11).

Alexander, E. J. s.n. (1b).

Allard, H. A. 25 (9).

Allison, A. $316(10)$.

Anderson, J. A. s.n. (9).

Anderson, J. P. s.n. (9).

Andrews, s.n. (5).

Armstrong, G. M. \& J. K. Armstrong s.n. (21c).

Arséne, Bro. 12173 (6).

Arséne, Bro. \& Bro. Benedict 17655 (18a).

Arthur, J. C. 21 (11).

Ashe, W. W. s.n. (1b); s.n. (21c).

Bachmann, F. A. \& J. Patrick s.n. (9).

Bacon, E. S. s.n. (11).

Baird, E. A. s.n. (18a).

Baker, C. F., F. S. Earle \& S. M. Tracy 1126 (18a).

Baker, H. P. s.n. (18a).

Ball, J. 525 (6).

Ballard, C. A. s.n., 58, 368 (11).

Barlow, B. s.n. (18a).

Bartholomew, E. 1 (11); s.n. (18a).

Bartlett, H. H. s.n. (5).

Bartley, F. \& L. L. Pontius s.n. (1a); s.n. (9).

Bartram, E. B. s.n. (9).

Bartsch, P. s.n. (11).

Bates, J. M. s.n. (4); s.n., 468 (11); s.n., 467 (18a).

Beal, W. J. s.n. (9).

Bebb, R. 1375 (15).

Beck, J. 26980 (9).

Bell, W. B. 95, 115 (11).

Benke, H. C. 5522 (9).

Benner, W. M. s.n. (5).

Bennett, J. s.n. (9); s.n. (11).

Berg, N. K. s.n. (6).

Bergman, H. F. 1851 (18a).

Bicknell, E. P. s.n. (1a); 246 (9).

Biltmore, Herb. $1037 b$ (1b); $5745 a$, $5745 d(9) ; 14928 a(21 \mathrm{c})$.
Birge, $\quad 3031$ (8).

Bitting, 49 (21c).

Blakley, O. W. 3440 (3); 1490 (9).

Blankinship, L. A. s.n. (18a).

Blankinship, J. W.s.n. (7); 57 (18a).

Blanton, F. S. s.n. (21c).

Blewitt, A. E. s.n. (5); 1350 (9).

Blumer, J. C. U104 (20).

Bodin, J. E. s.n. (7); s.n. (9).

Bogusch, E. R. s.n. (6); 547 (8); 905 (15).

Bower, R. E. s.n. (5).

Boynton, F. E. s.n. (5).

Brandegee, T. S. 70 (18a).

Bray, W. L. s.n. (18a).

Breakey, E. P. s.n. (9).

Bright, J. 4061 (17).

Brinton, J. B. s.n. (5).

Britton, N. L., E. G. Britton, \& A. M. Vail s.n. (1b).

Broadhead, G. C. s.n. (11).

Brown, A., A. T. Hogg, A. M. Vail, M. Timmerman, N. L. Britton, \& E. G. Britton, s.n. (5).

Brown, C. A. 5203, 3972 (6); 915 (10).

Brown, Z. D. E. s.n. (11).

Brumback \& Davies 17 (18a).

Buchholz, s.n. (9); s.n. (18a).

Bullard, s.n. (5).

Burgess, A. B. 779 (9).

Burgess, R. 16 (11).

Burk, M. 278 (9); 382 (11).

Bush, B. F. 194 (3); 1526, 2939 (4); 355, 2707 (5); 2391 (6); $578,1608,10467(7) ; 135,472$, $551,1527,2568,4547$ (9); 684, 1683 (11); 2699, 4350 (13); 1264 (18a).

Butler, B. T. 5012 (18a).

Butters, F. K., A. M. Johnson \& C. O. Rosendahl, s.n. (11).

Butters, F. K., C. O. Rosendahl \& Weiss, 2812 (18a). 
Bynum, Ingraham \& Jaynes s.n. (10).

Campbell, E. V. s.n. (18a).

Canby, W. M. s.n., 8475 (21c).

Canby, W. M., C. S. Sargent, \& B. F. Bush, 123 (18a).

Carpenter, M. s.n. (6).

Carter, Mrs. J. J. s.n. (9).

Cary, M. 745 (18a).

Chalmot, G. de, s.n. (5).

Chamberlain, E. B. s.n. (5).

Chandler, H. P. 7061 (22).

Chandonnet, Z. L. s.n. (11); s.n. (18a).

Chaney, M. 387 (10).

Chapman, A. W. s.n. (1b); s.n. (9); s.n. (21a).

Chase, V. H. 645 (9).

Cheney, L. S. 4203, 3569 (9).

Churchill, J. R. s.n. (1b); s.n. (9).

Clark, O. M. 2697 (9).

Clawson, A. B. 13919 (18a).

Cleborne, W. s.n. (1a).

Clemens, J. E. \& Mrs. J. E. Clemens, s.n. (18a).

Clemens, Mrs. J. E. 11521 (9); s.n., 11523 (18a).

Clements, F. E. 2591 (11).

Clifton, R. L. 3150 (18a).

Clokey, I. W. 2817 (18a).

Clothier, G. L. s.n. (11); s.n. (18a).

Clothier, G. L. \& N. N. Whitford, s.n. (9).

Clover, E. U. 176 (22).

Clute, I. M. 8 (6).

Clute, W. N. 11 (18a).

Cockerell, T. D. A. s.n. (18a).

Cocks, R. S. s.n. (6); s.n. (9); s.n. (10).

Coker, W. C. s.n. (1b).

Coker, W. C., H. R. Totten \& T. G. Harbison, s.n. (6).

Collins, J. F. 3674 (5); s.n. (9).

Commons, A. s.n. (5).

Cook, F. A. s.n. (9).

Core, E. L. s.n. (1b); s.n. (9).

Crampton, C. C. 139 (9).

Crandall, C. S. 2480 (18a).

Crocket, G. L. s.n. (6).
Curtis, L. B. s.n. (11).

Curtiss, A. H. s.n. (5); 2996, 4680, $5672,6667,(17) ; 4145,4748$ (21a).

Cuthbert, A. 667 (21c).

Daniels, F. s.n. (9).

Davis, J. 3604 (1a); s.n., 1240, $1665,4403,7360$ (5); 1270, $2358,4402,5713(9) ; 4436(11)$.

Davis, J. J. s.n. (11); s.n. (9).

Deam, C. C. s.n. 19, 1377, 2234, $6873,11193,11570,13534$, $13885,16630,16827,17308$, $17880,17893,41902,44823$ (1a); s.n., 5869, 27328, 33860, 40334, 40645, 41292, 42938, 44364, 46540, 46553 (5); s.n., $1138,1266,11049,11845$, 16812,31920 (9).

Deam, Mrs. C. C. s.n., 4065 (21b).

Deckard, W. W. s.n. (5).

Demaree, D. 7614 (18a).

Detwiller, s.n. (5).

Dewart, F. W. 88 (5); s.n. (9).

Dick, W. M. s.n. (9).

Diehl, I. E. s.n. (18a).

Dietz, H. s.n. (9).

Dimmit, R. 339 (9).

Dixon, R. A. 328 (14).

Dodd, T. C. Jr., 32 (7); s.n. (11).

Dodge, C. K. s.n. (9).

Dormon, C. 5 (6); s.n. (14).

Dorner, H. B. s.n. (9).

Dreisbach, R. R. 1461 (5).

Drummond, T. 429 (15).

Drushel, J. A. 3684 (1a); 6565 (5).

Duncan, T. J. 92 (18a).

Duval, H. H. s.n. (9); s.n. (15).

Eames, E. H. s.n. (5).

Earle, F. S. s.n. (1b); 742 (5); s.n., 2201 (9); s.n. (12); s.n. (18a).

Earle, F. S. \& C. F. Baker 565 (9).

Earle, F. S. \& E. S. Earle 7 (1b).

Eggert, H. s.n. (1a); s.n. (1b); s.n.

(5); s.n. (6); s.n. (9); s.n. (13);

s.n. (14); s.n. (15); s.n. (18a);

s.n. (21c). 
Eggleston, W. W. 4562 (1a); 4578 (9); 12502 (11); 15194 (18a).

Ehrler, E. s.n. (9).

Emig, W. H. 215 (1a); 573 (9); 435 (18a).

Engelmann, H. s.n. (9); s.n. (11).

Evermann, B. W. $696(9)$.

Fassett, N. C. 3300, 5107, 15107 (9); 16617 (11); 5110, 16062 (18a).

Fassett, N. C. \& N. Hotchkiss 3303 (18a).

Favor, E. H. s.n. (1a); s.n. (5).

Faxon, C. E. s.n. (1b).

Fendler, A. s.n. (6); 862 (18a).

Ferguson, A. M. s.n. (21b).

Fernald, M. L. 16514 (5).

Finch, O. s.n. (11).

Fink, B. s.n. (11).

Finkelnburg, W. A. s.n. (5).

Fitch, M. H. s.n. (11).

Fitzpatrick, T. J. s.n. (9); s.n. (11).

Flint, W. F. s.n. (7).

Forwood, W. H. 360 (11).

Frame, N. s.n. (18a).

Fraser, S. V. 58 (7); 60 (9); 59 (11).

Fredholm, A. 5040 (9).

Freiberg, G. W. s.n. (9); s.n. (11).

French, G. H. s.n. (1a).

Frost, W. D. s.n. (11).

Gamble, s.n. (5).

Garber, A. P. s.n. (21b).

Garesche, E. F. s.n. (9).

Garrett, A. O. 2962 (18a).

Gates, F.C. $1465,1507.1$ (5); 3022, 8847 (9); 13315 (11); 15141 (18a).

Gattinger, A. s.n. (5).

Geyer, C. A. s.n. (11).

Gibbes, L. R. s.n. (1b); s.n. (9); s.n. (21a).

Gilbert, A. H. 980 (5).

Gilbert, F. A. 101 (5).

Gleason, H. A. s.n. (1a); s.n. (9).

Goodding, L. N. 175 (18a); 733, 2405 (20).

Goodman, G. J. \& C. L. Hitchcock, $1117(18 \mathrm{a})$.
Gough, L. C. s.n. (7).

Gould, L. s.n. (7).

Graves, E. W. 2139 (5); 1940 (6); 1941 (9).

Green, T. s.n. (5).

Greene, E. L. s.n. (20).

Greene, F. C. s.n. (9).

Greenman, J. M. s.n., 1954 (9).

Griffin, s.n. (18a).

Grover, F. O. s.n. (9).

Haas, A. s.n. (10).

Hall, E. s.n. (6); 669 (16).

Haller, W. H. s.n. (9).

Hancin, J. 189 (7); 262 (11).

Hanson, D. F. s.n. (9).

Hapeman, H. s.n. (11); s.n. (18a).

Harbison, T. G. s.n. (6); 200 (16);

14791 (18a).

Harger, s.n. (5).

Harper, E. T. \& S. A. Harper, s.n. (11).

Harper, R. M. s.n., 42, 1296, 1907 (1b); s.n., 1370 (9); 21 (10); s.n., 30 (12); 771, 1314, 1331 (21a); 817, 913 (21c).

Harr, W. H. s.n. (9).

Harris, J. A. C2188 (9); C16469 (18b).

Harshberger, J. W. 9 (1b).

Havard, V. 80 (18a); s.n. (19).

Hawkins, L. A. s.n. (11).

Hayden, F. V. s.n. (9); s.n. (11).

Hayward, H. E. 2525 (18a).

Hayes, S. s.n. (15).

Heacox, s.n. (9).

Hedgcock, G. G. s.n. (18a).

Heinze, A. A. s.n. (3); s.n. (4); s.n. (7); s.n. (9); s.n. (11).

Heller, A. A. 179 (1b); s.n. (9); 14093 (21c); 1564 (22).

Herrick, C. L. 817 (18a).

Hexamer, A. C. 524 (21a).

Hexamer, A. C. \& Maier, s.n. (5); s.n. (21a).

Hicks, L. E. s.n. (1a); s.n. (5); s.n. (9).

Hill, s.n. (5). 
Hitchcock, A. S. s.n., 12652 (5); s.n. (9); s.n., $526 b$ (11); s.n. (18a); s.n., 1939 (21c).

Hobden, J. B. 1 (12).

Holgate, W. R. s.n. (18a).

Hollister, N. $36(9)$.

Holm, T. s.n. (5).

Holms, J. H. s.n. (11).

Holton, J. F. 10707 (1a); s.n. (9).

Holzinger, J. M. s.n. (11); s.n. (20).

Hood, S. C. s.n. (9); s.n. (21b); s.n. (21c).

Hopkins, M. H. s.n. (21b).

Horlacher, S. E. s.n. (1a); s.n. (5).

Hough, W. 9, 114 (18a); s.n. (18b); s.n. (20).

House, H. D. 3659, 4612 (1b); 2006, 3331 (9); 2509 (21a); 2591 (21c).

Howell, A. H. 330, 1149, 1153 (6); 669 (9); 24, 647 (18a); 1076, (21b).

Hubricht, L. s.n. (5); s.n. (11); s.n. (18a).

Huger, A. M. s.n., 19 (21c).

Hyams, C. W. s.n. (21a).

Hynes, M. s.n. (7).

Ikenberry, G. J. s.n. (7); s.n. (18a).

Imler, R. H. s.n. (9).

Jacobs, A. A. 56 (9).

James, J. F. s.n. (1a); s.n. (5).

Jaske, H. s.n. (5).

Jeffs, R. E. s.n. (9).

Jensen, M. C. s.n. (5).

Jermy, G. s.n. (6); s.n. (8); 344 (18a).

Jones, H. L. s.n. (11).

Jones, M. E. s.n. (11); 18576 (15); s.n., 5153, 5289w (18a); s.n. (18b).

Jones, W. W. s.n., 235 (18a).

Jones, Y. 32 (18a).

Kauffman, C. H. 170 (5).

Kayser, W. s.n. (5).

Kearney, T. H. Jr. s.n. (1a); 922 (1b); s.n. (5).

Kellerman, W. A. s.n. (9).
Kellogg, J. H. 542, 1650 (9); s.n. (11); s.n. (12).

Kennedy, G. G. s.n. (5).

Kincaid, R. R. s.n. (9).

King, A. 66 (1a); 437 (9).

King, H. F. 50 (9).

Knobloch, M. s.n. (16).

Kolthoff, I. s.n. (9).

Kramer, J. 180 (18a).

Krause, P. s.n. (9).

Lakela, O. 456 (18a).

Lands, M. E. s.n. (11).

Langlois, A. B. 362 (6); s.n. (18a).

Lansing, O. E. Jr. 3121, 3405, 4094 (9).

Lapham, I. A. s.n. (5).

Larson, A. H. s.n. (18a).

Larson, E. s.n. (13).

Lassiter, W. L. s.n. (9).

Laughlin, E. E. s.n. (9).

Lechner, C. D. s.n. (7).

Leeds, A. N. 1257 (1a).

Leonard, F. E. s.n. (9).

Lighthipe, L. H. s.n. (9); s.n. (21c).

Lindheimer, F. 174 (9); s.n. (15).

Link, E. S. s.n. (11).

Lippencott, C. D. s.n. (5).

Little, E. L. 590 (4); 593 (9).

Livingston, \& J. J. Thornber, s.n. (20).

Lloyd, C. G. s.n. (1a); s.n. (5).

Locke, O. s.n. (8).

Lodewyks, M. 162 (18a).

Long, B. s.n., 16362, 30393, 30632 (5).

Lough, W. s.n. (9).

Lunell, J. s.n. (18a).

Lute, M. W. s.n. (11).

Lynch, L. W. s.n. (1b).

Lyon, M. W. Jr. s.n. (9).

MacDougal, D. T. s.n. (1a); 1 (9); s.n., 48 (18a).

MacElwee, A. 208 (5).

MacFarlane, J. M. \& M. E. Davis s.n. (9).

Mackensen, B. 149 (8).

Mackenzie, K. K. s.n. (5); s.n. (11).

Mahoney, R. 113 (18a). 
Manning, S. M. s.n. (11).

Mansfield, I. F. s.n. (9).

Marrs, D. s.n. (16).

Marsh, C. D. s.n. (18a).

Mason, N. s.n. (11).

Matthews, W. 24 (20).

Mathias, M. E. 329 (18a).

Maus, P. s.n. (9); 179 (11).

McArthur, D. D. 2 (11).

McAtee, W. L. 3252 (9).

McBryde, J. B. s.n. (6); s.n. (16).

McCarthy, G. s.n. (1b); s.n. (21a).

McIntosh, A. C. 1377 (11).

McKee, L. s.n. (18a).

McLouth, C. D. s.n. (9).

McMullen, E. s.n. (15).

McVeigh, I. \& R. Kentner, s.n. (13).

Mearns, E. A. s.n. (5); s.n. (9). s.n. (11); s.n., 251 (18a); s.n. (21b).

Meehan, T., T. C. Porter, J. Leidy, \& J. Wilcox, s.n. (1b).

Meeker, G. s.n. (6).

Meislahn, M. 146a (21b).

Mell, C. D. 76 (18a).

Menzel, M. s.n. (11).

Mercer, E. 22 (16).

Meredith, s.n. (5).

Merriam, C. H. s.n. (9).

Merrill, F. J. H. s.n. (9).

Merrill, G.M. 210 (7).

Miller, G. S., Jr. S.n. (5); 385, 510 (9).

Milligan, Mrs. J. M. s.n. (11).

Millspaugh, C. F. s.n. (1a).

Moffatt, W. S. s.n. 1551/2, 302, 467 (9).

Mohr, C. s.n. (1a); s.n. (6); s.n. (9); s.n. (10).

Moldenke, H. N. 1135a (6); 166, $1078(9) ; 899$ (21b).

Moore, J. A. \& J. A. Steyermark, 3578 (19).

Moore, J. W. 3238 (9); 402, 404 (18a).

Morris, O. M. s.n. (18a).

Morrow, J. W. s.n. (11); s.n. (18a).

Moyer, L. R. 479 (18a); s.n. (11).

Munz, P. A. s.n. (18a).
Murdoch, J. Jr. 3013 (11).

Nash, G. V. 610 (9); 1574 (17); 879 (21c).

Nealley, G. C. s.n. (18a); 151 (20).

Neelly, E. s.n. (18a).

Nelson, A. 492, 2521, 7455, 8293, 8383 (18a).

Nelson, D. s.n. (9); s.n. (11).

Nelson, E. 4904 (18a).

Nelson, J. C. s.n. (11).

Norton, J. B. s.n., 526 (9); 14 (18a); s.n. (21c).

Nuttall, L. W. s.n. (1b).

Oberly, T. J. 2996 (9).

Oelmiller, A. s.n. (9).

Ohlinger, L. B. 47 (17); 1401 (21b).

O’Neil, H. s.n. (21b); 570 (21c).

Orcutt, C. R. 6072 (18a).

Osterhout, G. E. S.n. (18a).

Over, W. H. 2085, 6043 (11); s.n. 2662,15904 (18a).

Overholts, L. O. s.n. (1a).

Pace, L. s.n. (2); s.n. (18a).

Painter, J. H. 582 (5).

Painter, M. H. s.n. (7).

Palmer, E. J. 15508, 34802 (1a); 11475 (2); 20962, 27066 (3); $17431,21706,24763(4) ; 14972$, 30291 (5); 574, 5317, 7249, $7657 a, 12065,29671(6) ; 11792$ (8); s.n. 657, 7803, 29697, $34712,39831,40509,40564$ (9); 37172 (11); 24461, 29718, 38963, 39916 (12); 7968 (14); $11233, \quad 33396,33751$ (15); 39963 (17); 25067, 34484 (18a).

Palmer, E. J. \& J. A. Steyermark, $40763,40685,41757$ (1a); 40790, 41227, 41337 (9); 40989 (11).

Palmer, W. s.n. (21a).

Pammell, L. H. 168, 300 (18a).

Patterson, B. H. s.n. (9).

Patterson, H. N. s.n. (9).

Pease, A. S. 13062 (1a); 11940 (9).

Peattie, D. C. 1465 (1b).

Peckham, T. s.n. (9). 
Peebles, R. H., G. J. Harrison \& T. H. Kearney, 2794, 3177 (18b).

Pennell, F. W. 1387 (5); 6460 (9); 5751 (18a).

Pepoon, H. S. 542 (9).

Perley, G. A. s.n. (11).

Perrine, L. L. s.n. (11).

Peter, R. s.n. (5).

Petersen, N. F. s.n. (18a).

Pilsbry, H. A. s.n. (15).

Pitcher, Dr. s.n. (4).

Pollard, C. L. \& W. R. Maxon, 424 (1b).

Poole, C. F. 367 (11).

Pretz, H. W. 8147 (5); 6910 (9).

Price, S. F. s.n. (1a); s.n. (5).

Pringle, C. G. s.n. (18b).

Pyle, 625 (9).

Randolph, L. F. \& F. R. Randolph, 559 (21c).

Reid, E. L. \& D. Demaree, 7641 (18a).

Reppert, F. 655 (11).

Reverchon, J. s.n., 2479, 2480, $2481,4051,4052$ (6); 2771, 4049 (7); s.n. 2188, 2483, 2768, 4050 (9); s.n., 2770 (14); 4053a, 4055 (15); 4054 (16); s.n., $2482,2769,4053,4280$ (18a).

Reynolds, M. C. s.n. (21b).

Rich, s.n. (9).

Rider, S. 341 (18a).

Ridgway, R. s.n. (1a); s.n. (5); s.n. (9).

Roads, K. M. s.n. (1a); s.n. (5).

Rogers, Mrs. O. E. 31 (9).

Roofe, P. G. s.n. (9).

Rose, J. N. s.n. (1a); 42883 (18a).

Rosendahl, C. O. 5749 (18a).

Rosendahl, C. O. \& F. K. Butters, 2978 (9); 2905 (11); 3613 (18a).

Rothrock, J. T. 118 (18a); 372 (18b).

Ruddick, 264 (4).

Rugel, F. s.n. (1b).

Runyon, R. 677 (22).
Rusby, H. H. s.n. (1b); s.n. (18a); $414(20)$.

Rusby, W. S. s.n. (11).

Russell, C. s.n. (13).

Ruth, A. 265, 265 bis. (7); 766 (9); 705 (18a).

Rutter, C. s.n. (5).

Rydberg, P. A. 8234 (1b); s.n., 1053 (11); s.n., 1380 (18a).

Rydberg, P. A. \& A. O. Garrett, 9314 (18a).

Rydberg, P. A. \& R. Imler, 111, 339 (9); 560 (18a).

Rydberg, P. A. and F. R. Vreeland, 6449 (18a).

St. John, H. \& B. Long, 8053 (5).

Samples, J. s.n. (9).

Sandburg, J. H. s.n. (11).

Sarvis, J. T. 61 (18a).

Schaffner, J.H. s.n. (11); s.n. (18a).

Schaupp, F. G. s.n., 19 (8).

Schuette, J. H. s.n. (9); s.n. (11).

Schulz, E. D. 63 (22).

Scovell, J. T. s.n. (18a).

Scully, $\quad 90$ (4).

Sears, P. B. 1436 (9).

Selby, F. B. s.n. (9).

Shaddick, J. \& H. C. Skeels, s.n. (9).

Sharpe, Mrs. K. D. s.n. (5).

Shear, C. L. 26 (11).

Sheldon, C. S. s.n. (5).

Sheldon, E. P. s.n., 247 (11).

Shimek, B. s.n. (9); s.n. (11).

Shoop, s.n. (13).

Short, C. W. s.n. (1a).

Showalter, H. s.n. (12).

Shriver, H. s.n. (5); s.n. (9).

Skeels, H. C. 364 (9).

Skehan, J. s.n. (6).

Small, J. K. s.n. (1b); s.n. (9); s.n. 12 ; s.n. (17); s.n. (21a); s.n. (21c).

Small, J. K., E. Anderson, \& R. E. Woodson, Jr. s.n. (10).

Small, J. K., J. J. Carter, \& G. K. Small, 3387 (21b). 
Small, J. K. \& J. B. deWinkeler, Thornber, J. J. \& D. Griffiths, 184 9083; $9962(17)$.

(20).

Small, J. K. \& A. A. Heller s.n. (1b). Thurber, G. s.n. (9).

Small, J. K. \& C. A. Mosier, \& Tims, E. C. s.n. (6).

J. B. deWinkeler, 10871 (17). Toumey, J. W. 439 (18b).

Small, J. K., K. W. Small, \& J. B. Tracy, S. M. 3219, 5123, 5125, deWinkeler, 10784 (21b).

Small, J. K. \& E. T. Wherry, 11700 (6).

Smith, B. H. s.n. (18a).

Smith, C. E. s.n. (12).

Smith, E. s.n. (5).

Smith, G. W. s.n. (5).

Smith, H. H. 5956, 6872, 7228 (9).

Smith, J. D. s.n. (21b); s.n. (21c).

Smith, J. G. \& Lee, 7684 (18a).

Smith, J. G. \& R. Pound, s.n. (18a).

Snow, F. H. 2997 (7); s.n. (9).

Somes, M. P. s.n. (11).

Standley, J. P. 431 (21b).

Standley, P. C. s.n. (7); 9138 (9); 40539 (19).

Stanfield, S. W. s.n. (18a).

Steele, E. S. s.n. (5); 27, 43 (9).

Stevens, G. W. $1381(6) ; 619,3222$ (18a).

Steyermark, J. A. s.n., 13076, $13196,14276,15527,16335$, 18820 (1a); 18542 (4); 15778 (5); 18626,18627 (13).

Straub, F. C. 64 (9).

Studhalter, R. A. 1180 (18a).

Sullivant, E. 81 (9).

Swezey, G. D. s.n. (11).

Taylor, Mrs. B. s.n. (9). 5126, 7488 (6); 3086, 3229, 5127,6387 (9); 8046 (18a); 6755 (21b).

Tweedy, F. s.n. (18a).

Tyler, E. E. s.n. (11).

Tyler, F. J. s.n. (18a).

Umbach, L. M. s.n. (9).

Univ. Nebr. Herb. 457 (9).

van Cleve, s.n. (9).

van Pelt, S. S. s.n. (5).

van Vleet, A. H. s.n. (9).

Vardell, M. L. s.n. (21c).

Vasey, G. R. s.n. (12).

Vestal, A. G. s.n. (18a).

Vickers, Mrs. W. H. s.n. (9).

Visher, S. S. 421, 4069 (11); 1566, 2303 (18a).

Waite, M. B. s.n. (9).

Walker, G. H. s.n. (9).

Wallace, E. J. 23 (18a).

Waller, A. E..s.n. (9).

Walpole, B. A. s.n. (5).

Ward, L. F. s.n. (5); s.n. (21c).

Warner, S. B. s.n. (6).

Washburn, E. W. s.n. (11).

Weatherby, C. A. 5177 (5); 6116 (21c).

Webb, T. N. s.n. (1b).

Taylor, B. C. 176, 578, 783 (11); 1424 (18a).

Taylor, K. A. s.n. (5).

Tharp, B. C. s.n. (2); s.n. (6); s.n., 2187 (8); s.n. (9); s.n., 2186 (14); s.n., (15); s.n., 2879, 5658 (16); s.n., 20, 1256, 3340 (18a); s.n., 1134 (22).

Webber, H. J. s.n., 4871 (18a).

Weber, C. 179 (18a).

W. V. U. (West Virginia Botanical Expedition) 1401 (9); 972 (1b).

Wetzstein, A. s.n. (9).

Wheeler, C. P. s.n. (9).

Wheeler, H. E. s.n. (21c).

Wheeler, W. A. 410 (9).

Tharp, B. C. \& E. Anderson, s.n. (2).

Thompson, E. J. s.n. (11).

White, B. J. s.n. (7); 5 (18a).

Whitehouse, E. s.n. (14); s.n. (18a).

Wichita Univ. s.n. (9).

Thomson, H. s.n. (11).

Wickersheim, W. J. s.n. (11).

Thornber, J. J. s.n. (11); 10 (18a). Wiegand, K. M. 450 (18a). 
Wiegand, K. M. \& W. E. Manning, Woodson, R. E. Jr. \& L. Hubricht, 714 (1b); 717 (9); 715 (17); $\quad$ s.n. (4); s.n. (6); s.n. (7); s.n. $722(21 \mathrm{a}) ; 720,721(21 \mathrm{c})$.

Wiegand, K. M. \& G. B. Upton, Woodson, R. E. Jr., L. Hubricht \& 3029 (18a).

Wilcox, T. E. s.n. (11).

Wilkinson, E. 10601 (9).

Williams, E. F. s.n. (5).

Williamson, C. S. s.n. (1b); s.n (18a).

Williamson, E. B. s.n. (9).

Willis, J. G. s.n. (5).

Wilson, H., s.n. (11).

Wimpey, P. H. s.n. (9).

Winchell, N. H. s.n. (9).

Wislizenus, F. 422 (5).

Wolden, B. O. $1079 a$ (11).

Woods, P. O. s.n. (18a).

Woodson, R. E. Jr. 3300 (5); 195, 326 (9); s.n. 325 (13). J. A. Steyermark, s.n. (3); s.n. (4); s.n. (13).

Woodson, R. E. Jr. \& J. A. Steyermark s.n. (5).

Wooton, E. O. s.n., 543 (18a); s.n. (20).

Wright, A. H. 118 (21a).

Wright, C. s.n. (2); 701 (19).

Wurzlow, H. s.n. (9); s.n. (15).

Young, M. S. s.n. (1a); s.n., $33(6)$; s.n. (9); $72(15)$.

Yuncker, T. G. 197 (5).

Zuck, M. s.n. (18b). 


\section{EXPLANATION OF PLATES}

\section{PLATE I}

Root systems of representative species of Tradescantia (all $\times 2 / 3$ ).

Fig. 1. Tradescantia rosea Vent. var. ornata (Small) Anderson \& Woodson, from H. N. Moldenke 899 (in herb. Missouri Botanical Garden), collected in dry sandy pineland, Fort Myers, Lee County, Florida.

Fig. 2. Tradescantia pinetorum Greene, from L. N. Goodding 2405 (in herb. Missouri Botanical Garden), collected in moist sheltered places, Miller Peak, Huachuca Mts., Arizona.

Fig. 3. Tradescantia subacaulis Bush, from H. Eggert s. n. (in herb. Missouri Botanical Garden), collected in sandy prairies, Victoria County, Texas.

Fig. 4. Tradescantia Reverchoni Bush, from J. Reverchon s. n. (in herb. Missouri Botanical Garden), collected in sands, near Swan, Texas.

Fig. 5. Tradescantia rosea Vent. var. graminea (Small) Anderson \& Woodson, from A. A. Heller 14093 (in herb. Missouri Botanical Garden collected in sand, on Atlantic Coastal Plain, White Lake, Bladen County, North Carolina.

\section{PLATE II}

Leaf surfaces of representative species of Tradescantia from living specimens (all $\times 35$ ), photographed with reflected illumination. Lower and upper surfaces of identical leaves to left and right respectively.

Fig. 1. Tradescantia subaspera Ker-Gawl. var. typica, from plants collected in Saint Louis County, Missouri.

Fig. 2. Tradescantia virginiana L., from plants collected in Saint Louis County, Missouri.

Fig. 3. Tradescantia canaliculata Rafinesque, from plants collected in Jefferson County, Missouri.

Fig. 4. Tradescantia paludosa Anderson \& Woodson, from plants collected in Orleans Parish, Louisiana.

\section{PLATE III}

Flower buds of representative species of Tradescantia from living specimens $($ all $\times 5)$.

Fig. 1. Tradescantia bracteata Small, from plants collected in Saint Charles County, Missouri.

Fig. 2. Tradescantia virginiana L., from plants collected in Jefferson County, Missouri.

Fig. 3. Tradescantia occidentalis (Britton) Smyth, var. typica, from plants collected in Tarrant Councy, Texas.

Fig. 4. Tradescantia canaliculata Rafinesque, from plants collected in Saint Louis County, Missouri.

Fig. 5. Tradescantia canaliculata Rafinesque, from plants collected in Saint Louis County, Missouri. 


\section{PLATES IV AND V.}

Calyces of Tradescantia and Callisia species from herbarium specimens $($ all $\times 5)$. Names and numbers, in parentheses refer to collector and collector's number.

Fig. 1. Tradescantia subaspera var. typica (Rose s.n.).

Fig. 2. Tradescantia edwardsiana (Anderson 6).

Fig 3. Tradescantia hirsutiflora (Fisher 307).

Fig. 4. Tradescantia gigantea (Tharp 2187).

Fig. 5. Tradescantia Ernestiana (Palmer 21706).

Fig. 6. Tradescantia paludosa (Small, Anderson, \& Woodson s.n.).

Fig. 7. Tradescantia canaliculata (Yuncker s.n.).

Fig. 8. Tradescantia virginiana (Seaman s.n.).

Fig. 9. Tradescantia Tharpii (Ruth 265).

Fig. 10. Tradescantia longipes (Bush 2781).

Fig. 11. Tradescantia subacaulis (Reverchon 4054).

Fig. 12. Tradescantia pinetorum (Jones s.n.).

Fig. 13. Tradescantia rosea var. graminea (Biltmore Herbarium 3632-b).

Fig. 14. Tradescantia Reverchoni (Reverchon 1905).

Fig. 15. Tradescantia rosea var. typica (Harper 1314).

Fig. 16. Tradescantia roseolens (Nash 1574).

Fig. 17. Tradescantia rosea var. ornata (Mearns s.n.).

Fig. 18. Tradescantia humilis (Wurzlow s.n.).

Fig. 19. Tradescantia occidentalis var. typica (Clokey 2817).

Fig. 20. Callisia cordifolia (Anderson s.n.).

\section{PLATE VI}

Calycine pubescence of representative species of Tradescantia from herbarium specimens $($ all $\times 100)$.

Fig. 1. Tradescantia bracteata Small, from G. W. Freiberg s. n. (in herb. Missouri Botanical Garden), collected in Houston County, Minnesota.

Fig. 2. Tradescantia pinetorum Greene, from $L$. N. Goodding 2405 (in herb. Missouri Botanical Garden), collected in moist, sheltered places, Miller Peak, Huachuca Mts., Arizona.

Fig. 3. Tradescantia roseolens Small, from $A$. H. Curtiss 5672 (in herb. Missouri Botanical Garden), collected in low, open woods, near Jacksonville, Florida.

Fig. 4. Tradescantia canaliculata Rafinesque (barbate specimen), from J. B. Norton 526 (in herb. Missouri Botanical Garden), collected in sandy soil, Riley County, Kansas.

Fig. 5. Tradescantia virginiana L., from $H$. Eggert s. n. (in herb. Missouri Botanical Garden), collected on hills, near Victoria, Jefferson County, Missouri.

Fig. 6. Tradescantia gigantea Rose, from G. Jermy s. n. (in herb. Missouri Botanical Garden), collected in Gillespie County, Texas. 
Fig. 7. Tradescantia hirsutiflora Bush, from G. W. Stevens 1381 (in herb. Missouri Botanical Garden), collected near Page, Leflore County, Oklahoma.

Fig. 8. Tradescantia hirsuticaulis Small, from E. J. Palmer 24461 (in herb. Missouri Botanical Garden), collected near Hot Springs, Garland County, Arkansas.

Fig. 9. Tradescantia longipes Anderson \& Woodson, from Woodson छ Hubricht s. n. (in herb. Missouri Botanical Garden), collected in Iron County, Missouri.

Fig. 10. Tradescantia occidentalis (Britton) Smyth var. typica, from M. E. Mathias 329 (in herb. Missouri Botanical Garden), collected west of Fleming, Colorado.

Fig. 11. Tradescantia micrantha Torr., from H. P. Chandler 7061 (in herb. Missouri Botanical Garden), collected at Rio Hondo, Cameron County, Texas.

\section{PLATE VII}

Seeds of representative species of Tradescantia $($ all $\times 9$ ). Micropylar and funicular surfaces to left and right respectively.

Fig. 1. Callisia cordifolia (Sw.) Anderson \& Woodson, from A. S. Hitchcock 361 (in herb. Missouri Botanical Garden), collected near Fort Myers, Lee County, Florida.

Fig. 2. Tradescantia pinetorum Greene, from J. M. Holzinger s.n. (in herb. Missouri Botanical Garden), collected in East Canyon, Grant County, New Mexico.

Fig. 3. Tradescantia Wrightii Rose \& Bush, from C. Wright 701 (in herb. New York Botanical Garden), collected probably in the Guadelupe Mts., Culberson County, Texas.

Fig. 4. Tradescantia rosea Vent. var. typica, from $R$. M. Harper 1314 (in herb. Missouri Botanical Garden), collected in imperfectly developed sand-hills, between Groveton and Bel Air, Georgia.

Fig. 5. Tradescantia bracteata Small, from $M$. Burk 382 (in herb. Missouri Botanical Garden), collected along prairie roadsides, Black Hawk County, Iowa.

Fig. 6. Tradescantia canaliculata Rafinesque, from J. B. Norton s.n. (in herb. Missouri Botanical Garden), collected near Manhattan, Kansas.

Fig. 7. Tradescantia virginiana L., from J. Davis 7360 (in herb. Missouri Botanical Garden), collected along damp bluffs, near Foristell, Saint Charles County, Missouri.

Fig. 8. Tradescantia occidentalis (Britton) Smyth var. typica, from E. J. Palmer 34484 (in herb. Missouri Botanical Garden), collected along Limpia Creek, near Fort Davis, Jeff Davis County, Texas. (All seeds from the same capsule).

\section{PLATE VIII}

Tradescantia Ernestiana, habit $(\times 1 / 3)$, from a living specimen collected at the type locality near Wilson's Spring Creek, Jasper County, Missouri. 


\section{PLATE IX}

Tradescantia Tharpii, habit $(\times 1 / 3)$ in bloom and in fruit, from living specimens collected at the type locality, near Carthage, Jasper County, Missouri.

\section{PLATE X}

Tradescantia longipes, habit $(\times 1 / 3)$, from a living specimen collected at the type locality, near Arcadia, Iron County, Missouri.

\section{PLATE XI}

Tradescantia paludosa, habit $(\times 1 / 3)$, from a living specimen collected at the type locality, near Gentilly, Orleans Parish, Louisiana.

\section{PLATE XII}

Tradescantia ozarkana, habit $(\times 1 / 3)$, from a living specimen collected at the type locality, near Roaring River Spring, Barry County, Missouri. 


\section{INDEX}

Synonyms are printed in italics; new names in bold-face type.

Acremonium, 21

Allium sive Moly Virginianum, 8

Bartram, John \& William, 31

Bauhin, Caspar, 8

Bush, B. F., 12

Callisia cordifolia, 117

- umbellulata, 118

Calyx, discussion of, 20

Chromosome number, 30, 35, 36, 88

Clarke, C. B., 11

Corolla, Discussion of, 22

Crocus, Wild, 93

Cuthbertia, 19

- graminea, 115

- ornata, 114

- rosea, 112

Cytology, 30

Darker, G. D., 21

Ephemerum congestum, 61

Ephemerum phalangiodes tripetalon Virginianum gramineum, 9

Fassett, N. C., 67

Grass violet, 97

Haas, Anna L., 42

Habit, Discussion of, 13

Hemerophytes, 30

Hybridization, Diagram illustrating intra-specific and inter-specific, 36, fig. 2

- Map showing effect of, 38, fig. 3

Hybrids, experimental, 32,33

- natural, 32

Indument, Discussion of, 24

Inflorescence, Discussion of, 19

Leaf, Figure showing shape of, 16, fig. 1

Leaves, Discussion of, 15

Leiandra cordifolia, 117

Linnaeus, C., 10

Micropyle, 28

Morison, Robert, 9

Palmer, Ernest J., 60

Parkinson, John, 8

Pedicels, Discussion of, 20

Phalangium Ephemerum Virginianum Iohannis Tradescant, 8

Piper, C. V., 18

Polyploidy, 30

Primitive element, 54

Rafinesque, C., 10, 65

Relict species, 54

Root hairs, 14, 95

Roots, Discussion of, 13

Rose, J. N., 12

Ruppius, H. B., 10

Seeds, Discussion of, 27

Self-sterility, 29

Showalter, H. M., 41
Small, John K., 11, 82

Spiderwort, 9

Stamens, Discussion of, 23

Stomata, Discussion of, 17

Tharp, B. C., 42, 72

Tradescant, John, 8

Tradescantella Floridana, 117

Tradescantia, 44

- albida, 61

- australis, 68

- axillaris, 50

- flexuosa, 50

- barbata, 75

- - pumila, 75

- trachiloma, 75

- bracteata, 47, 48, 85, 86, map 11

- $X$ canaliculata, 41

- $\times$ Tharpii, 42

- brevicaulis, $61,65,71,92$

- canaliculata, 46, 74, 75, 76, map 9

- $\times$ gigantea, 40

- $\times$ hirsutiflora, 40

$-\infty$ humilis, 32

- $\times$ longipes, 41

- $X$ occidentalis, 35

- $\times$ rosea, 41

- $X$ subaspera, 40

- $X$ virginiana, 40

- caricifolia, 75

- ciliata, 61

- comata, 52

- congesta, 61

- cordifolia, 117

- cristata, 49

- difforme, 101

- discolor, 61

- - ramosa, 61

- divaricata, 75

- edwardsiana, 45, 54, 55, map 2

- eglandulosa, 68

- elata, 101, 108

- Ernestiana, 45, 58, 59, map 4

- $X$ ozarkana, 40

- flexuosa, 50

- Floridana, 117

- foliosa, 75

- gigantea, 46, 73, 76, map 8

- glabra, 61

- graminifolia, 112

- Harbisoni, 97

- hirsuticaulis, 47, 89, 90, map 12

- $X$ virginiana, 41

- hirsutiflora, 46, 47, 67, 68, map 6

- $\times$ paludosa, 42

- humilis, 47, 95, 96, map 15

- $X$ occidentalis, 42

- incarnata, 75 
Tradescantia intermedia, 96

- laevigata, 75

- - incarnata, 75

- Laramiensis, 101

- linearis, 109

- longifolia, 99

- longipes, 47, 91, 92, map 13

- Lyonii, 75

- micrantha, 48, 116, 117, map 22

- montana, 52

- occidentalis, 48, 101, 102, map 18

- - scopulorum, 101, 102, 106, map 18

- - typica, 101, 102, map 18

- X canaliculata, 38,107 , fig. 3

-Ohioensis, 75

- ozarkana, 45, 56, 57, map 3

- paludosa, 46, 83, 84, map 10

- pilosa, 49,53

- pinetorum, 48, 110, 111, map 20

- pumila, 61

- ramifera, 101

- Chandonnetii, 101

- reflexa, 75, 82

- - albiflora, 75

- - drepisia, 75

- Lesteri, 75

- - Mariae, 75

- Reverchoni, 47, 94, 95, map 14

- riparia, 75

- rosea, 48,111

- - graminea, 112, 113, 114, map 21

- - ornata, 112, 113, 114, map 21

- - pauciflora, 112

- - typica, 112, 113, map 21

- roseolens, 48, 98, 99, map 17
Tradescantia rupestris, 61

- scopulorum, 106

- sive Ephemerum Virginiana, 10

- Speciosa, 61

- subacaulis, 47, 97, 98, map 16

- subaspera, 45, 49, 50, map 1

- montana, 49, 50, 52, map 1

- typica, 49, 50, map 1

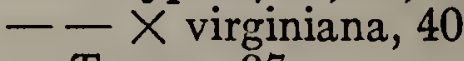

- Texana, 97

- Tharpii, 42, 46, 70, 72, map 7

- trachyloma, 75

- tuberosa, 110

- universitatis, 101

- vaginata, 101

- villossima, 50

- virginiana, 45, 46, 60, 61, 62, map 5

- Virginiana occidentalis, 101

— virginica, 61

- Virginica alba, 61

- - albiflora, 62

- - angustifolia, 61

- - barbata, 61

- Drummondii, 96

- flexuosa, 50

- pilosa, 50

- - purpurea, 61

- - ramosa, 61

- - villosa, 62

- Wrightii, 48, 108, 109, map 19

Vegetative propagation, 27, 117

Violet, Grass, 97

Watson, Sereno, 11

Widow's tears, 22

Wild crocus, 93 


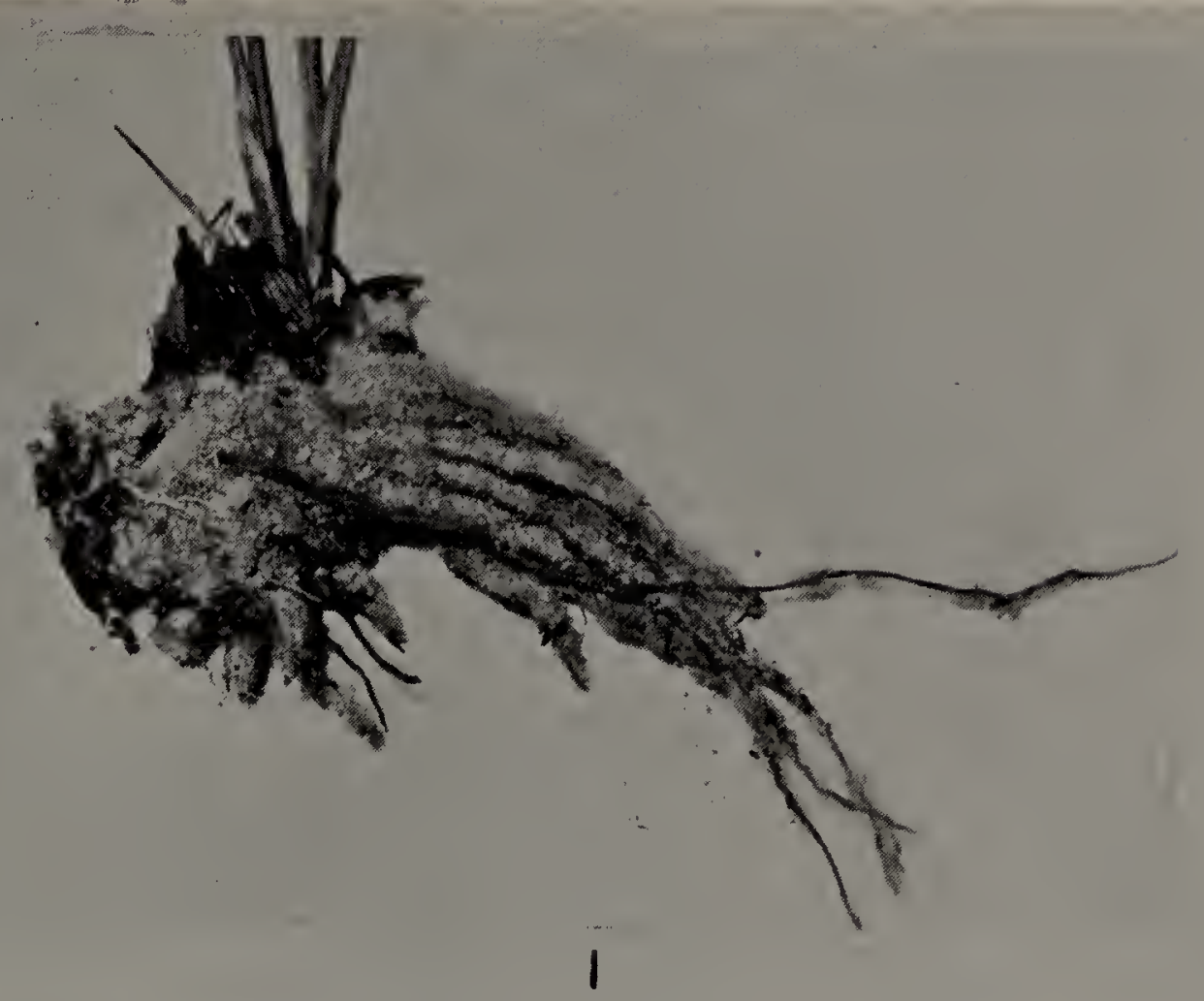

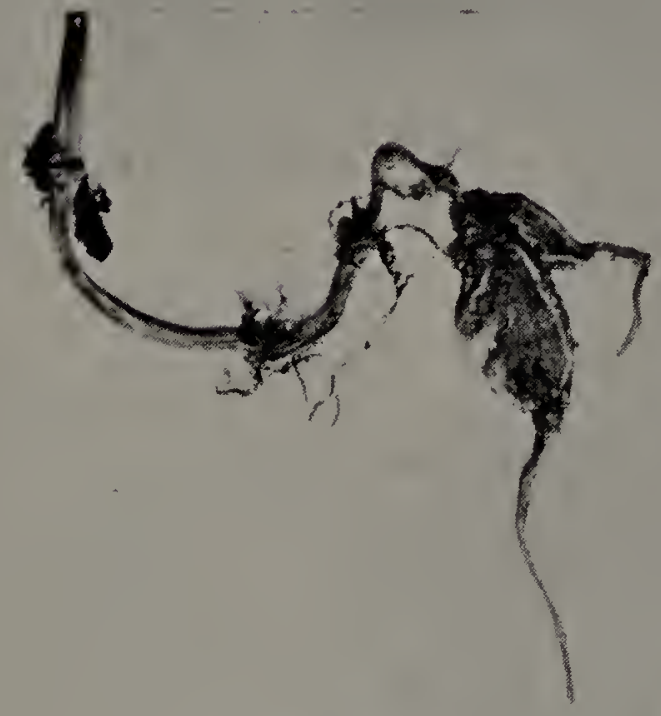

2

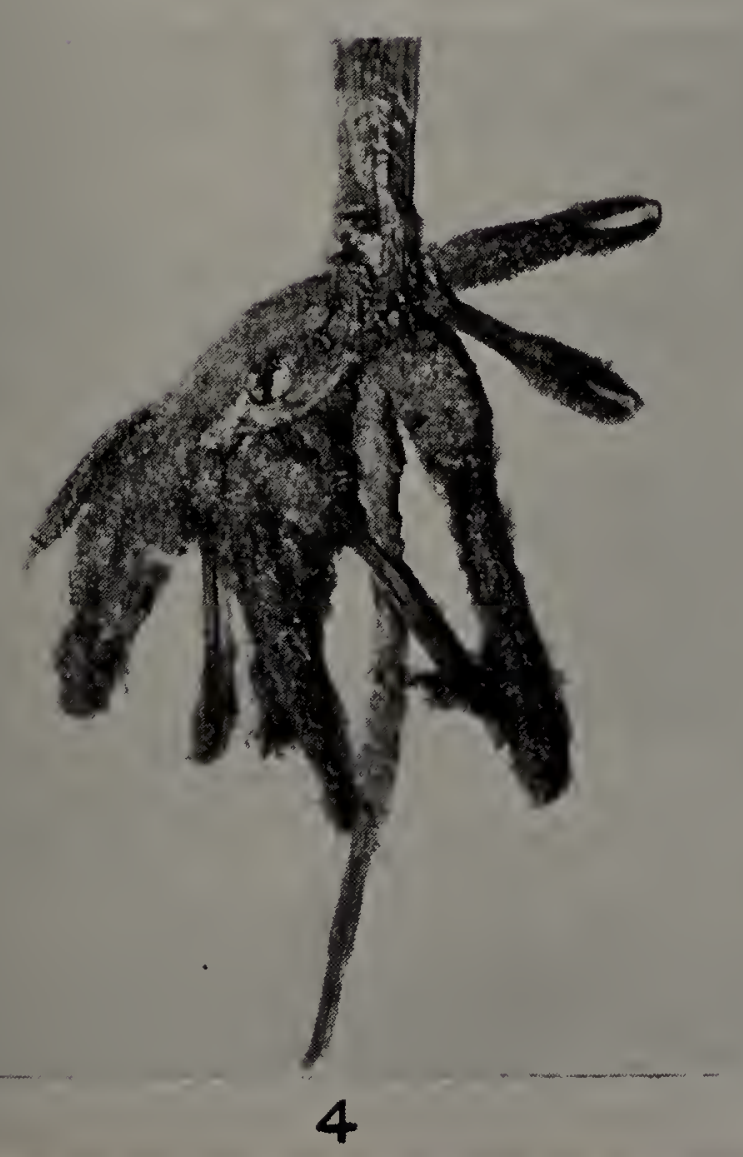

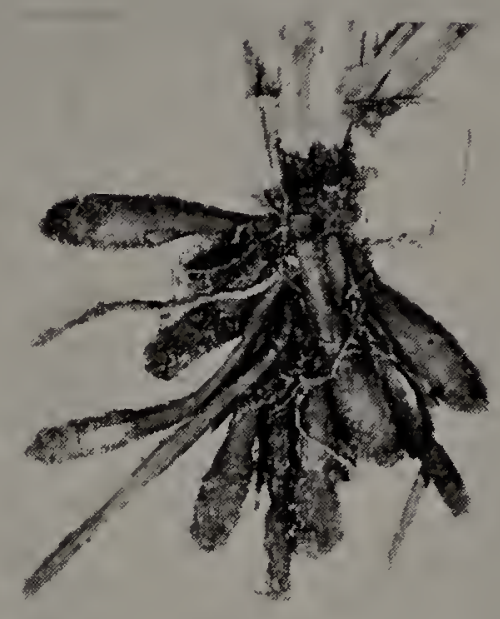

3

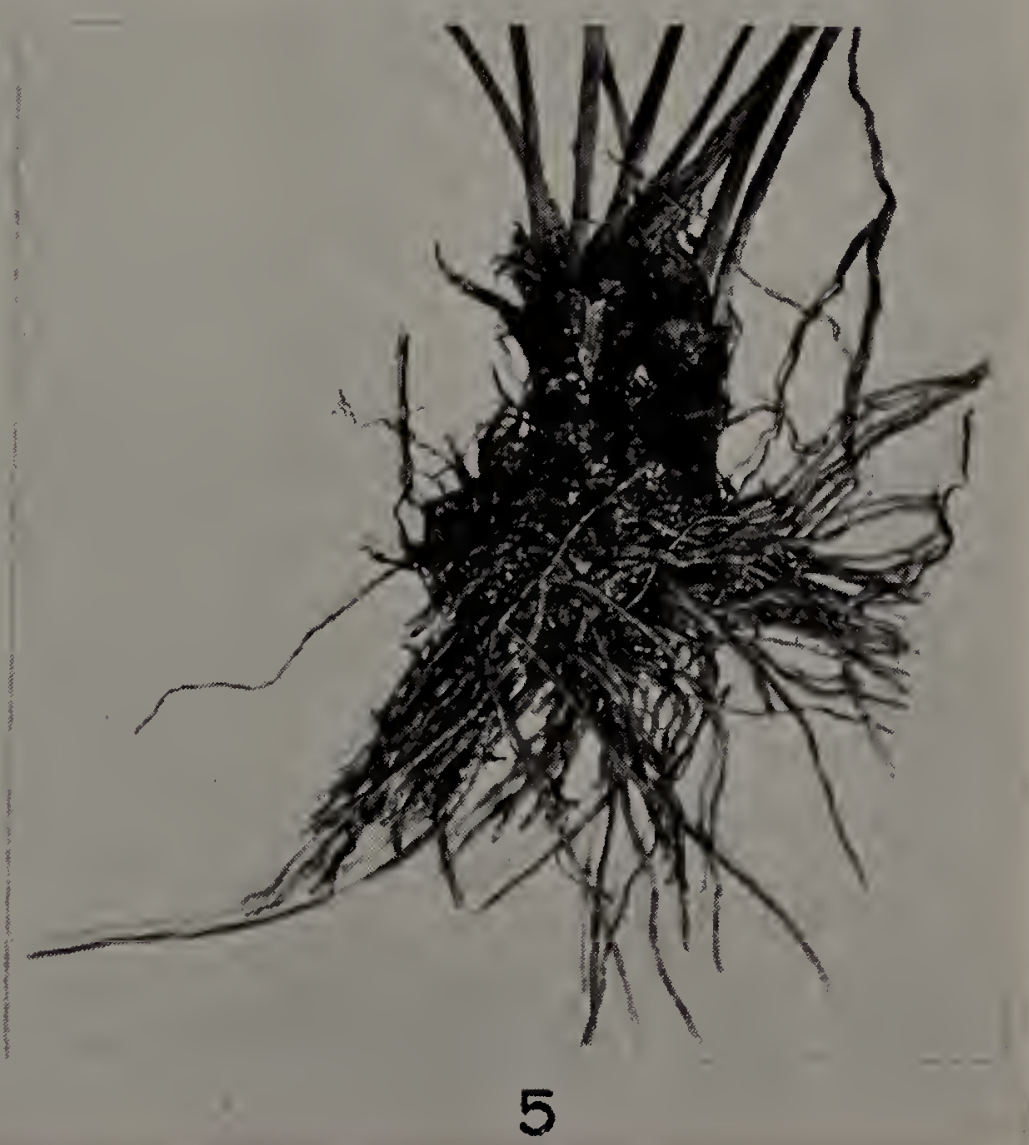

Root Systems of Representative Species of Tradescantia. 


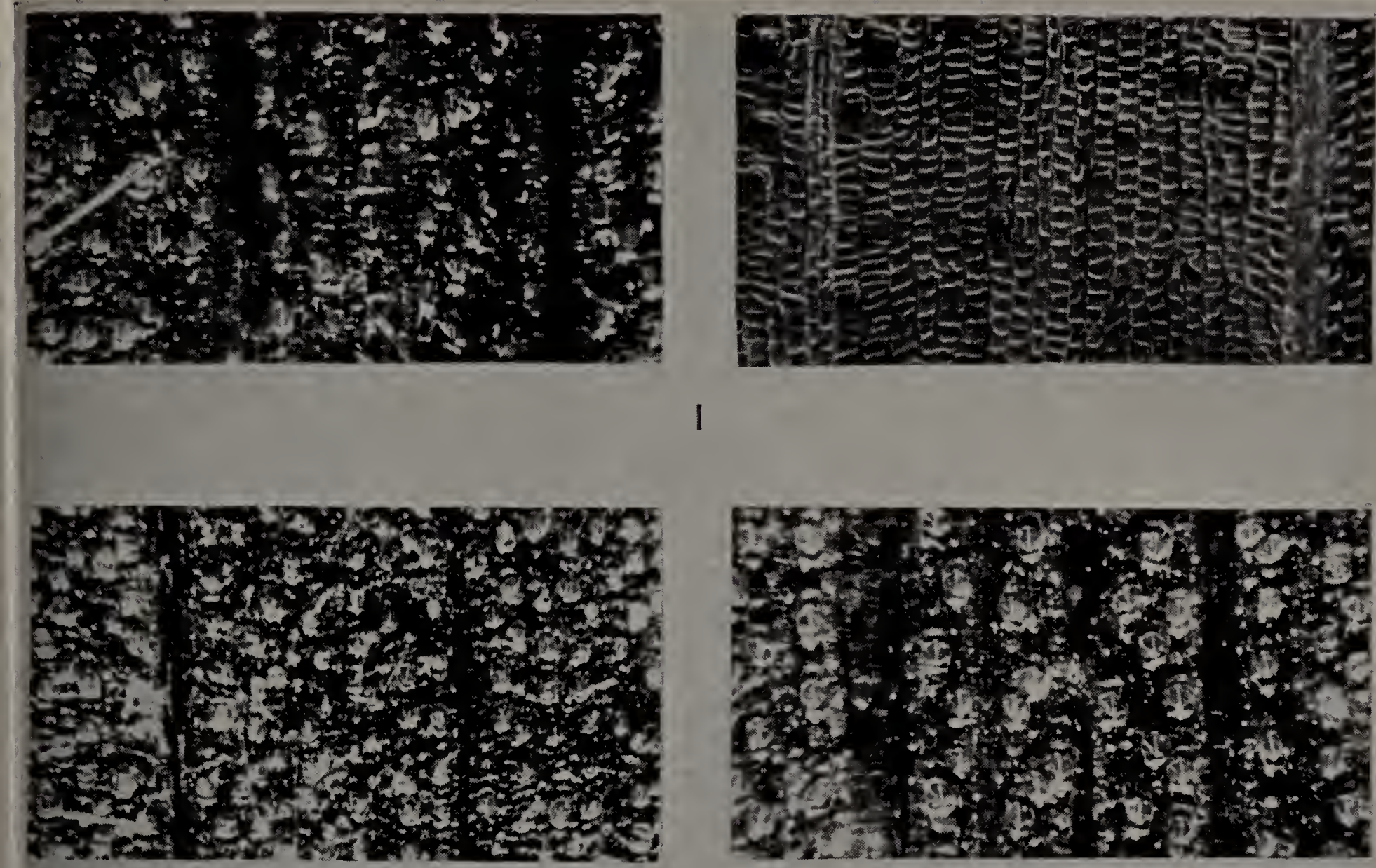

2
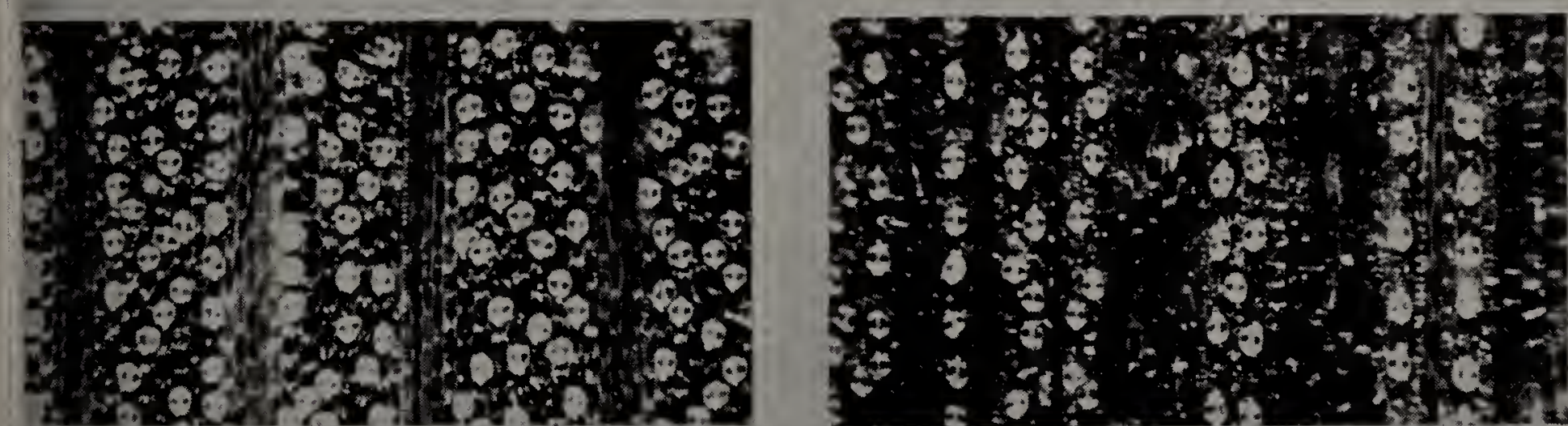

3
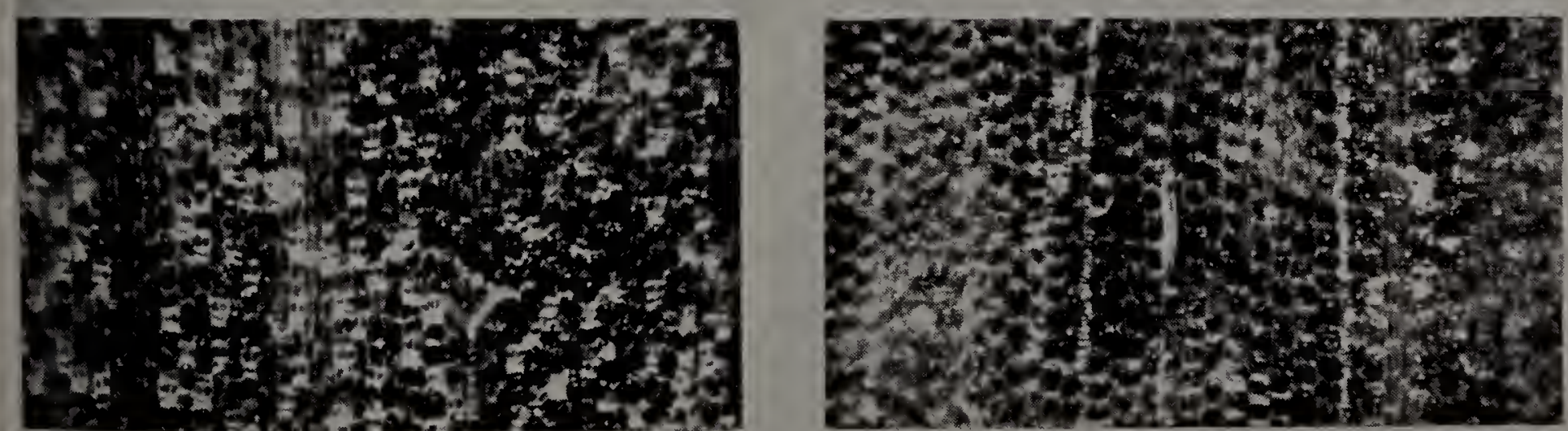

4

Leaf Surfaces of Representative Species of Tradeșcantia, 


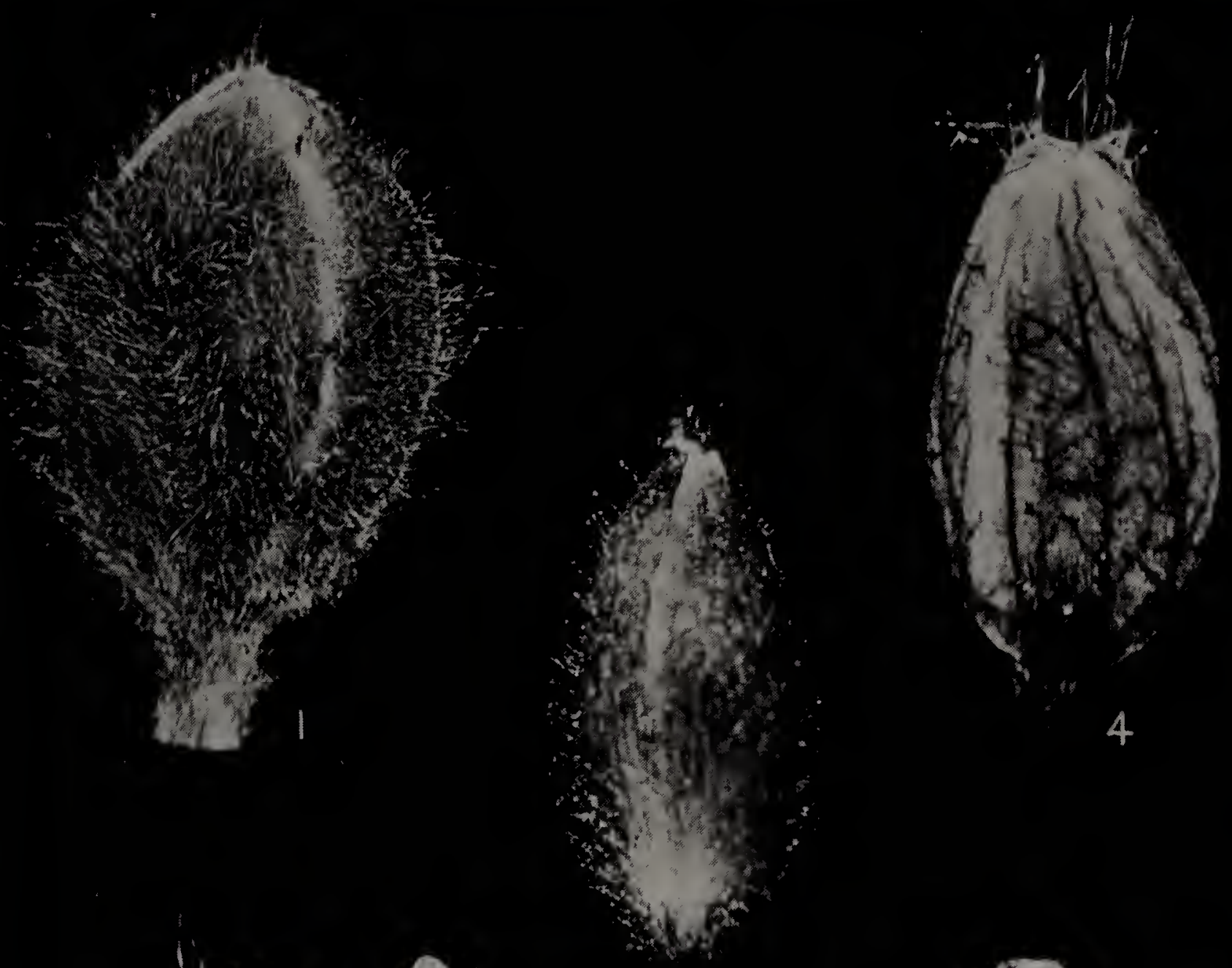

4

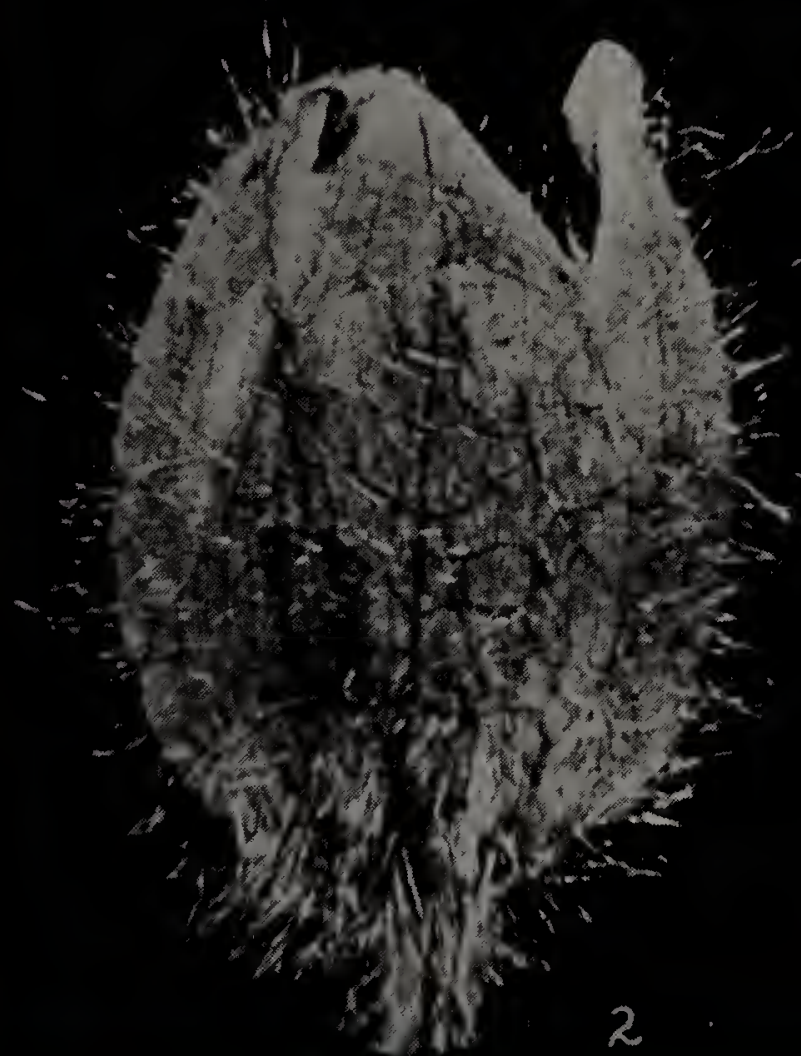

3

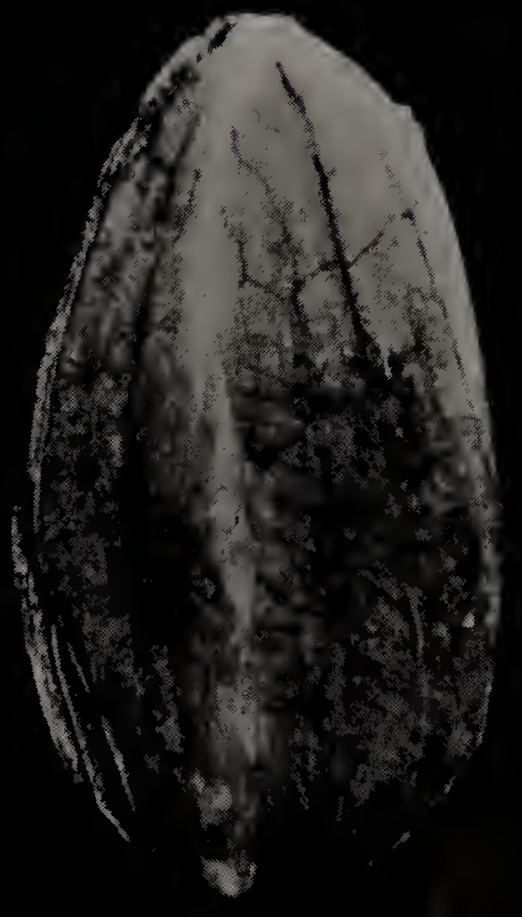

5

Flower Buds of Representative Species of Tradescantia. 



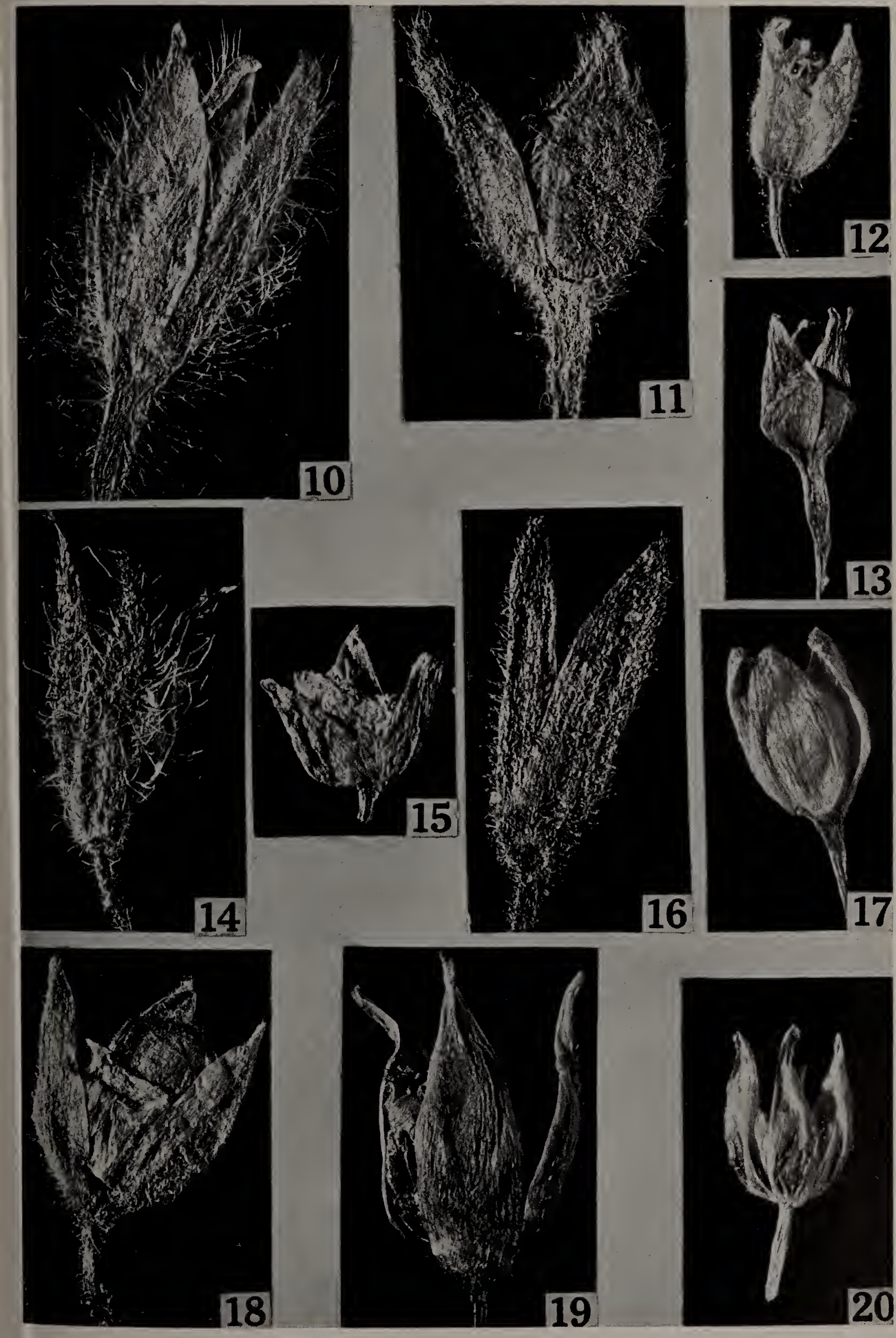

Calyces of Tradescantia and Callisia Species. 


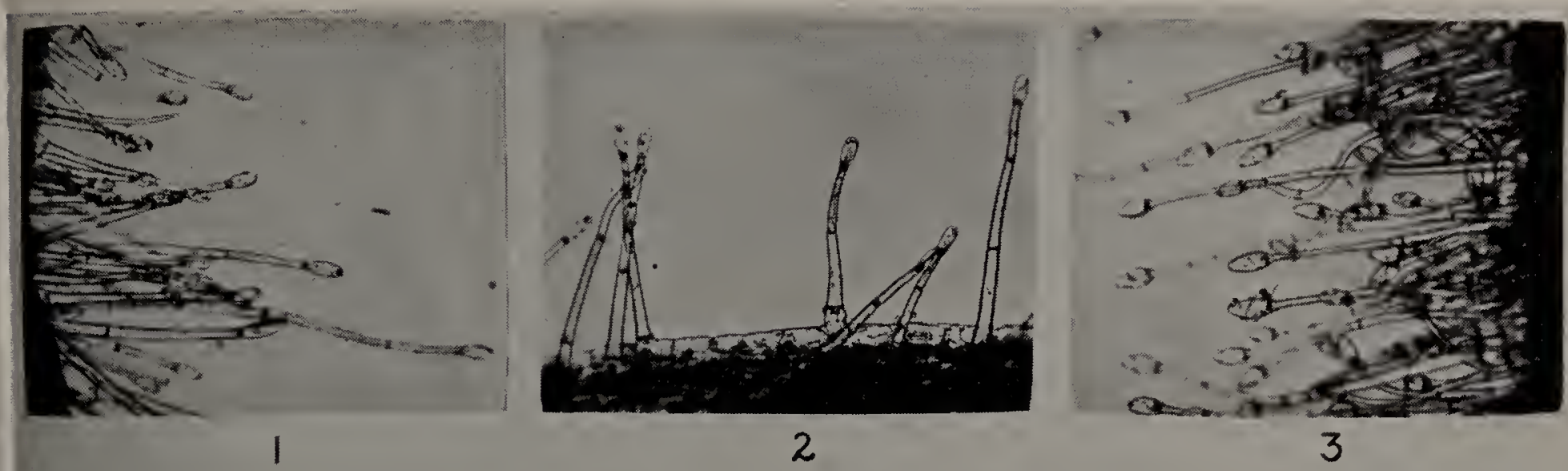

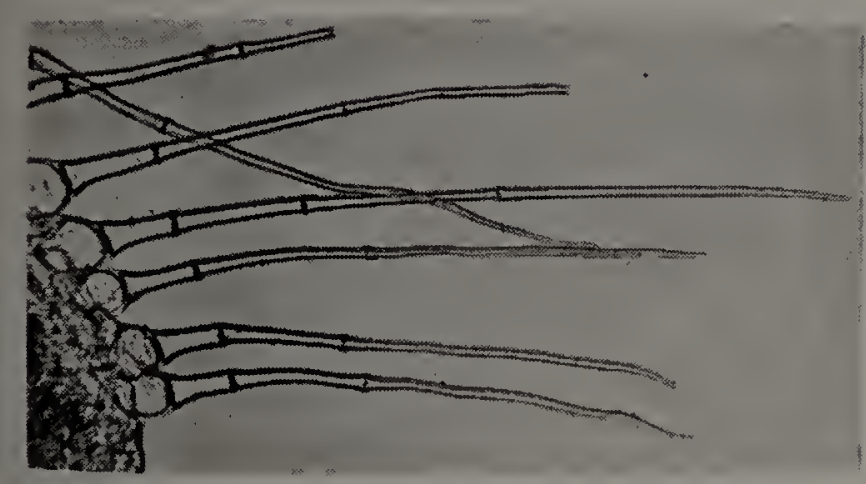

4

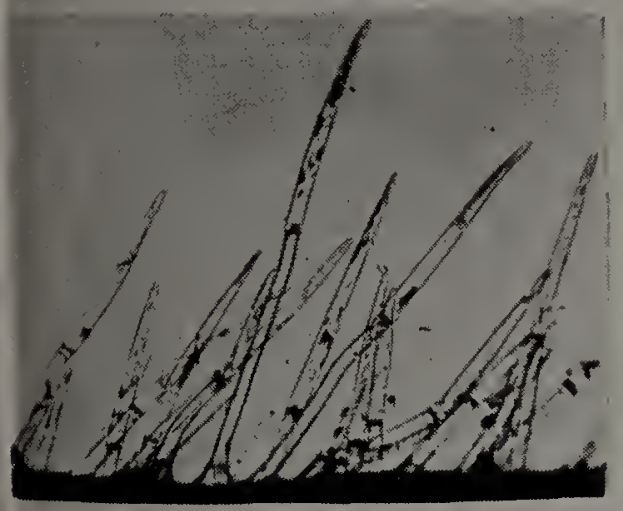

6

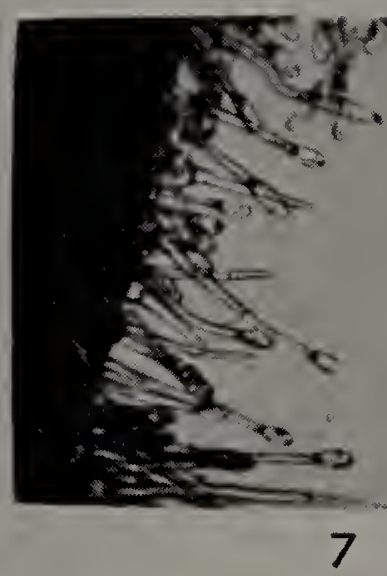

7

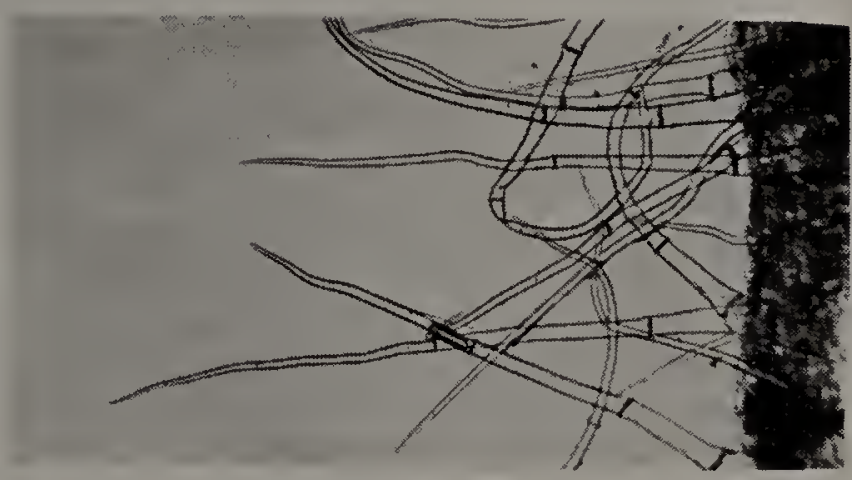

5

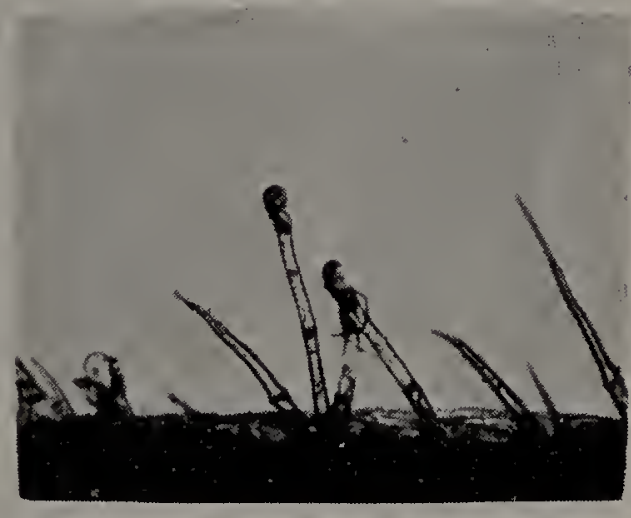

8

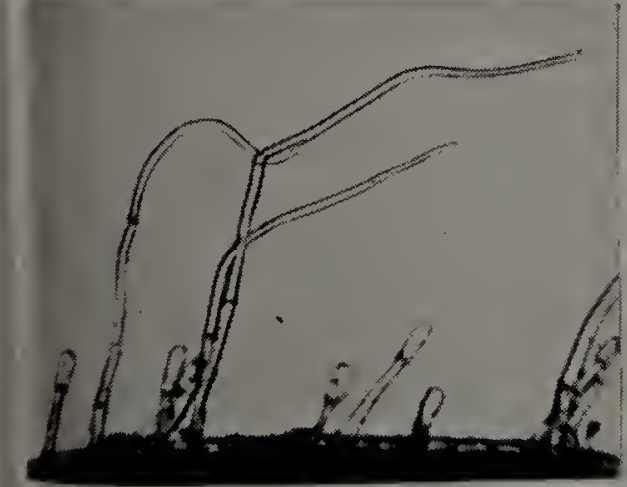

9

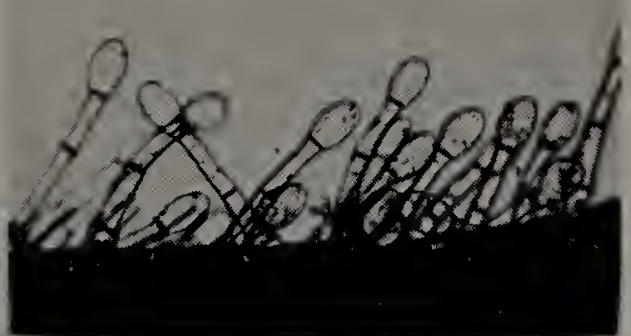

10

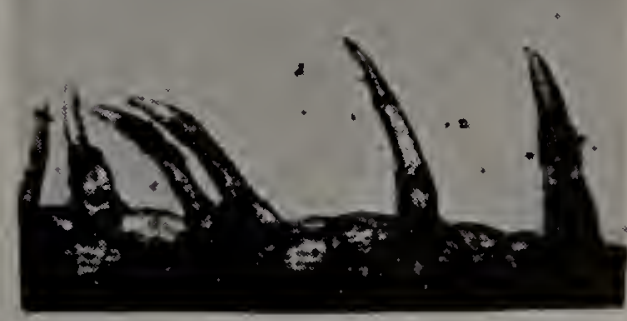

11

Calycine Pubescence of Representative Species of Tradescantia. 



\section{ing (4)}
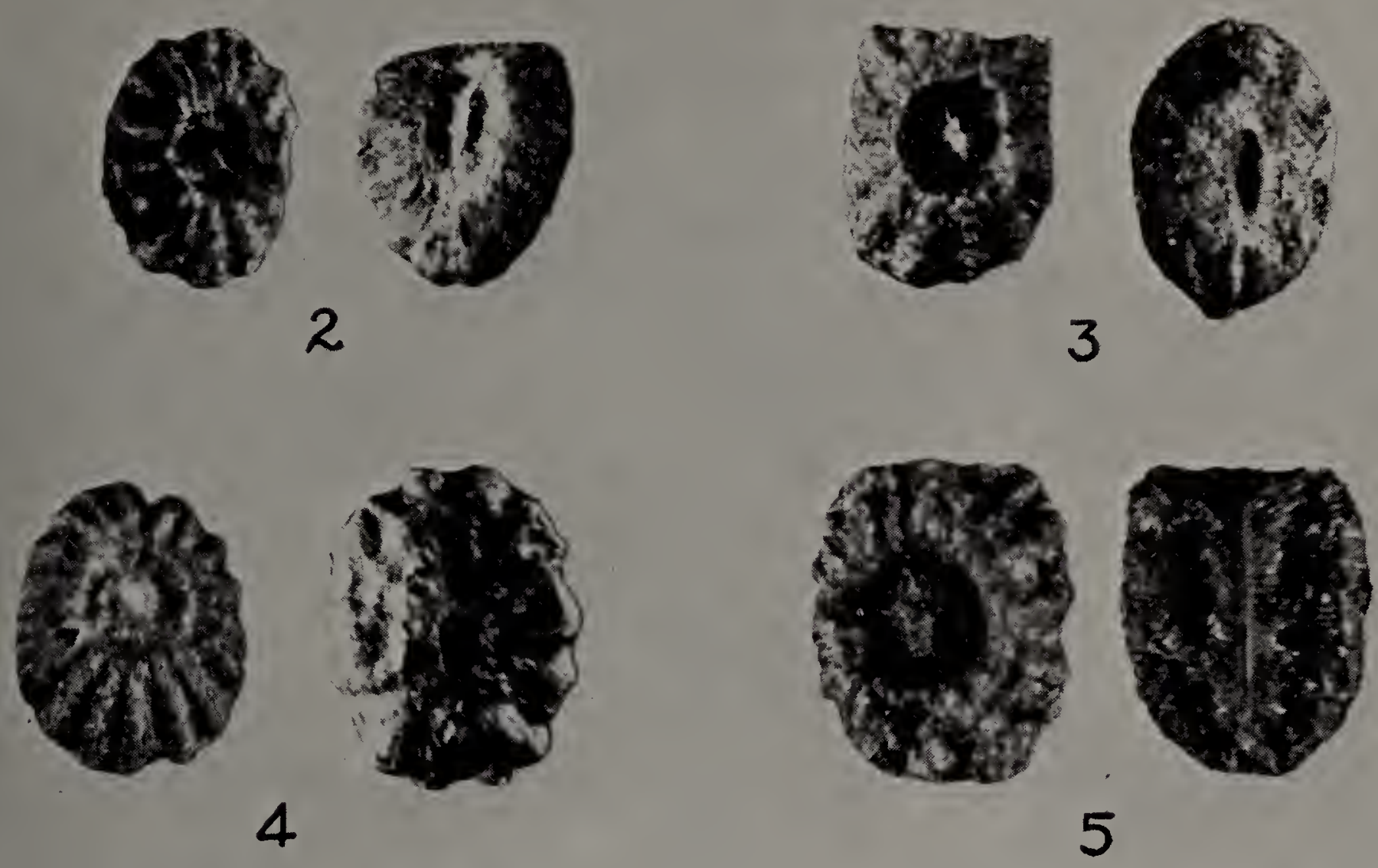

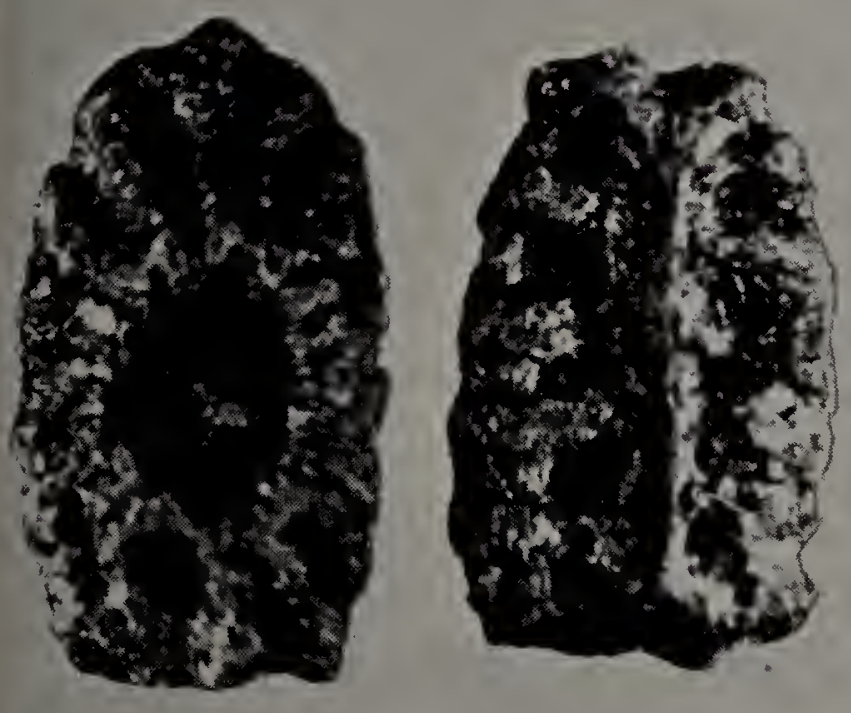

6

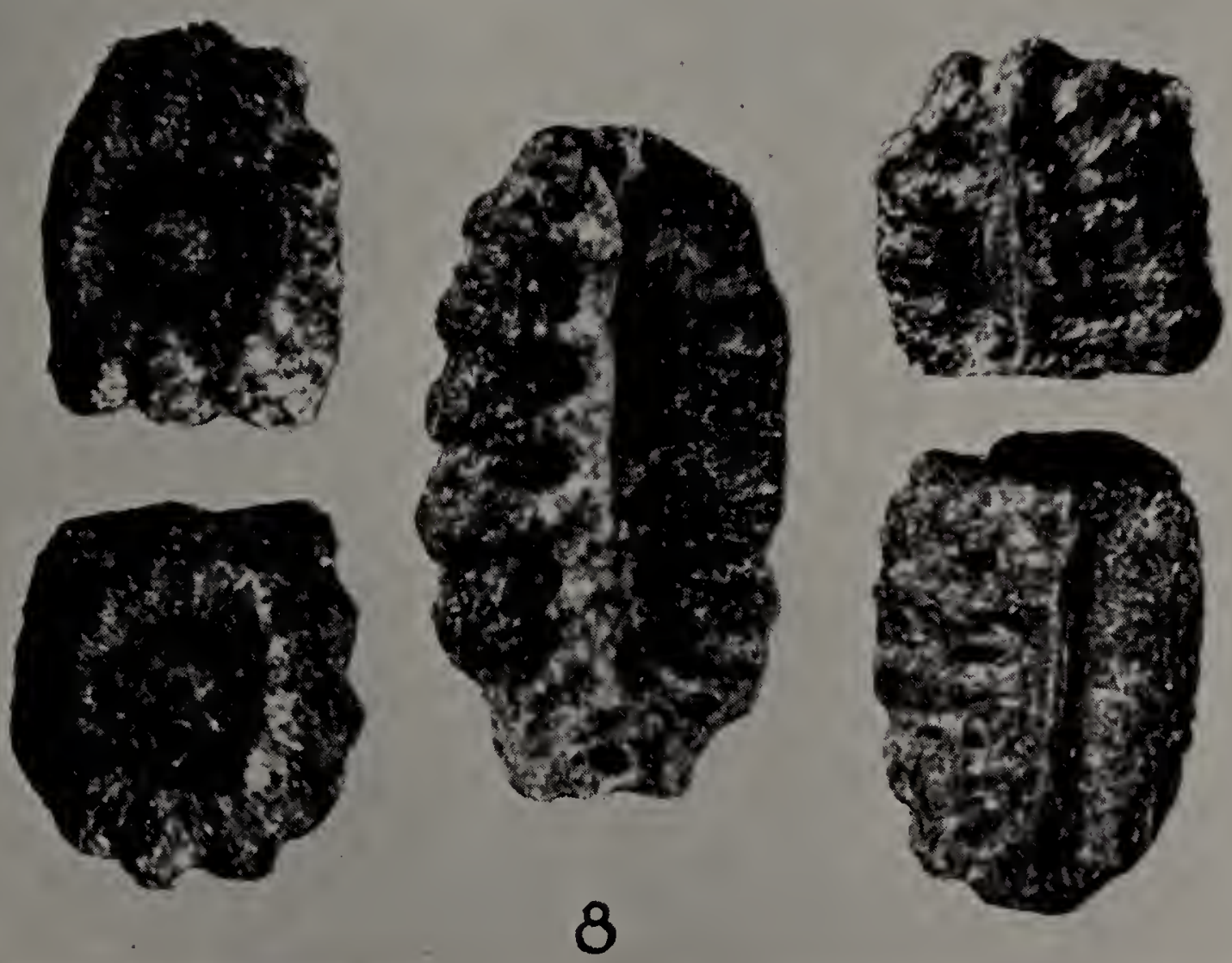





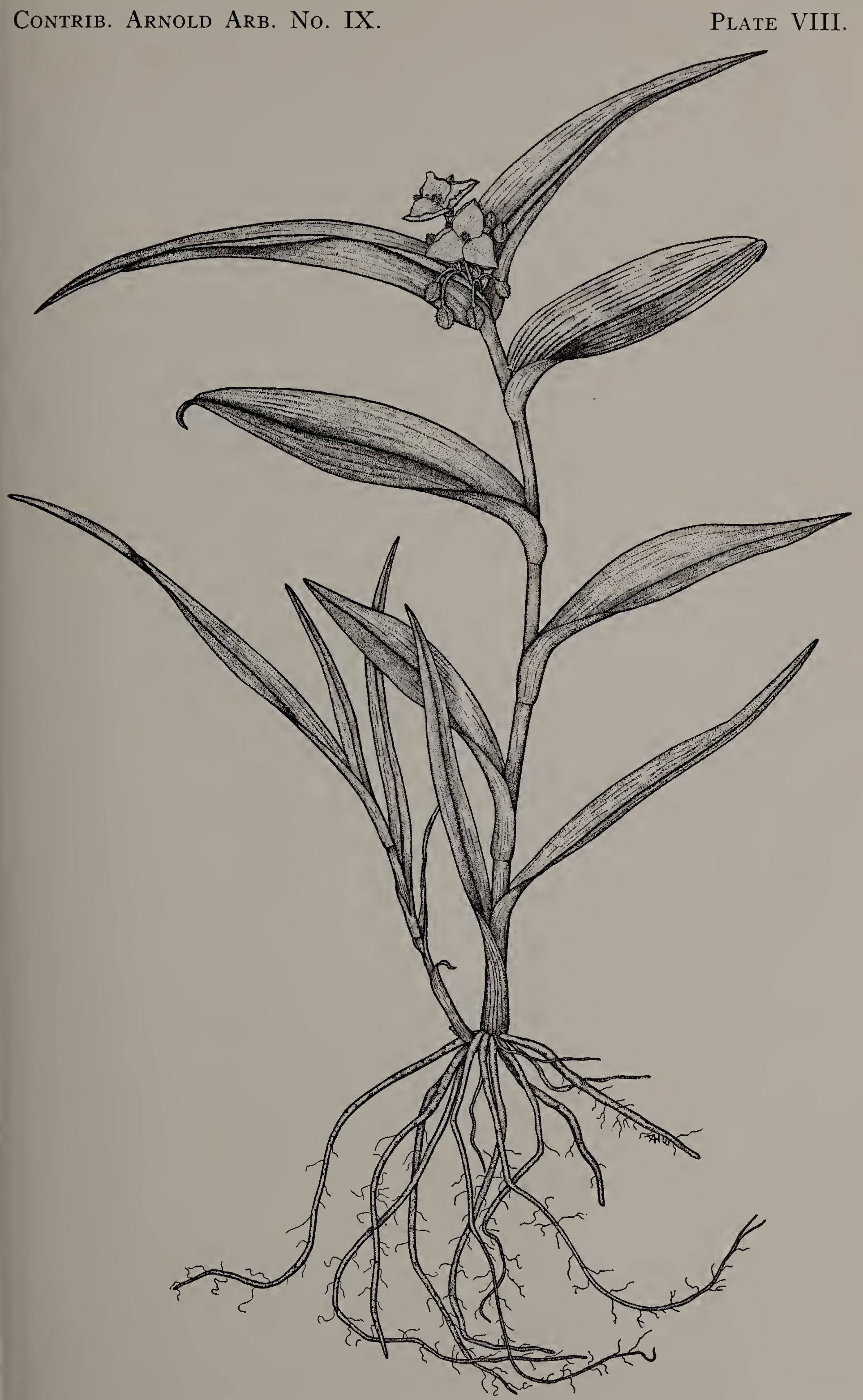

Tradescantia Ernestiana Anderson \& Woodson. 



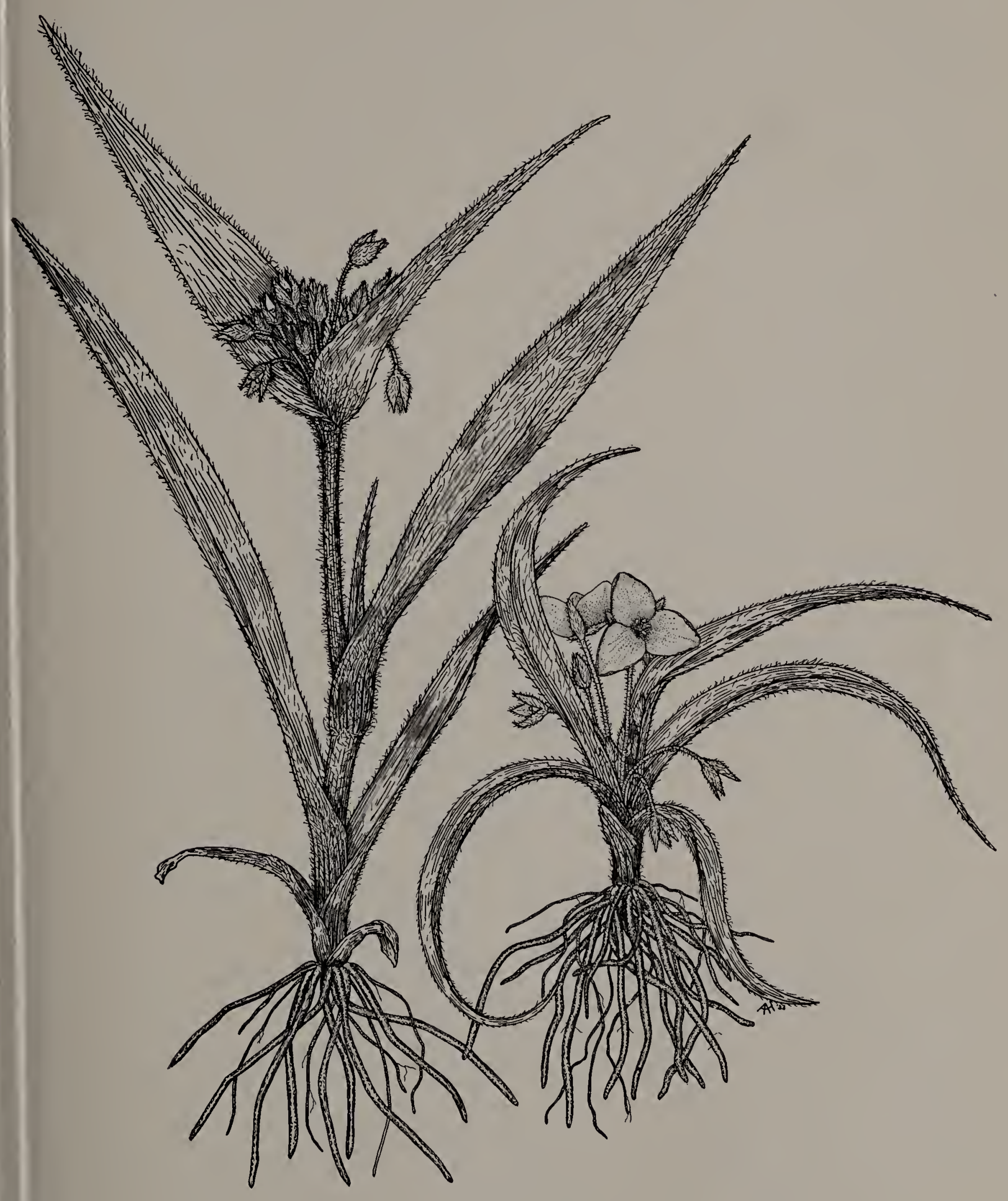

Tradescantia Tharpil Anderson \& Woodson. 



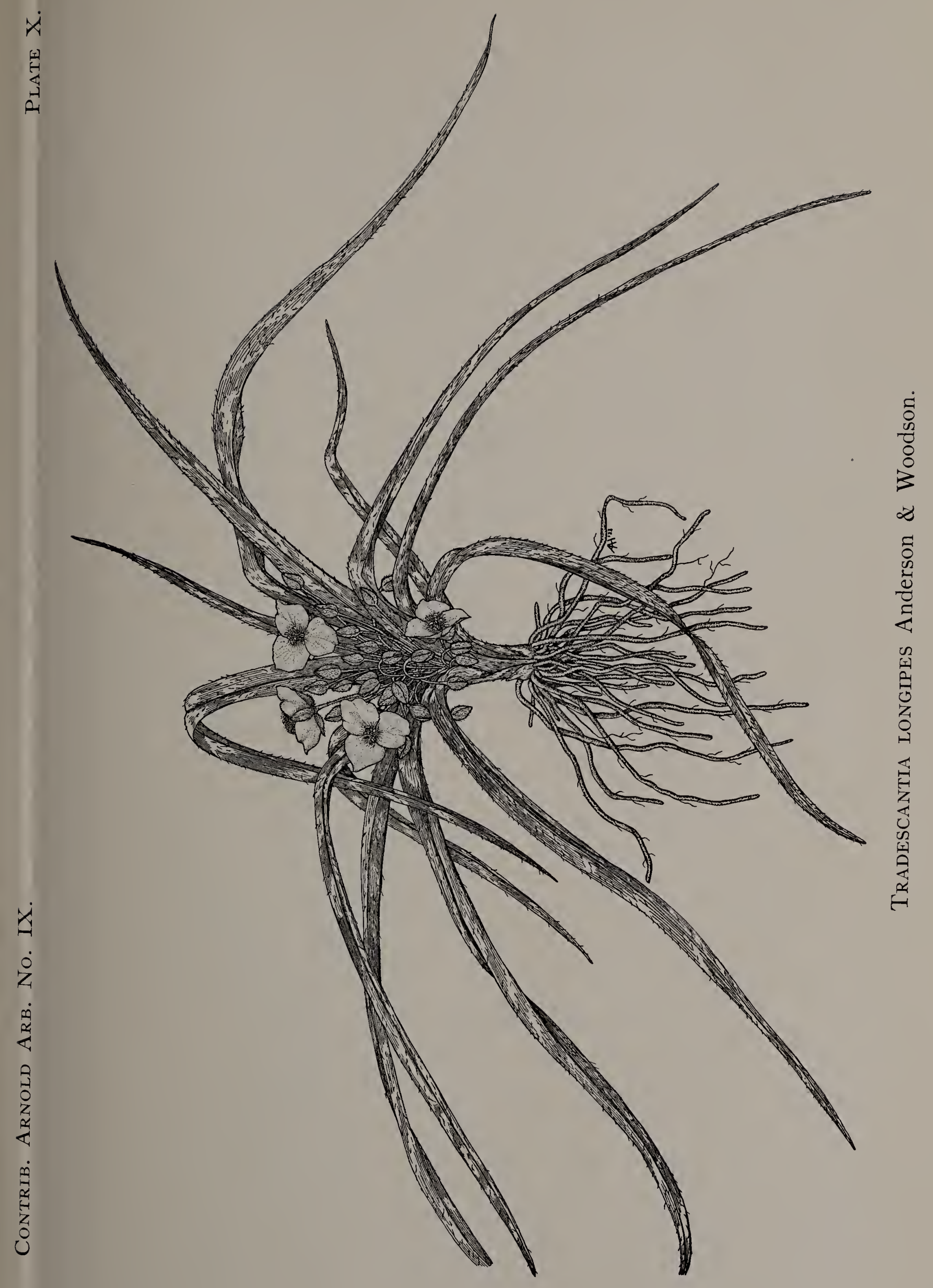





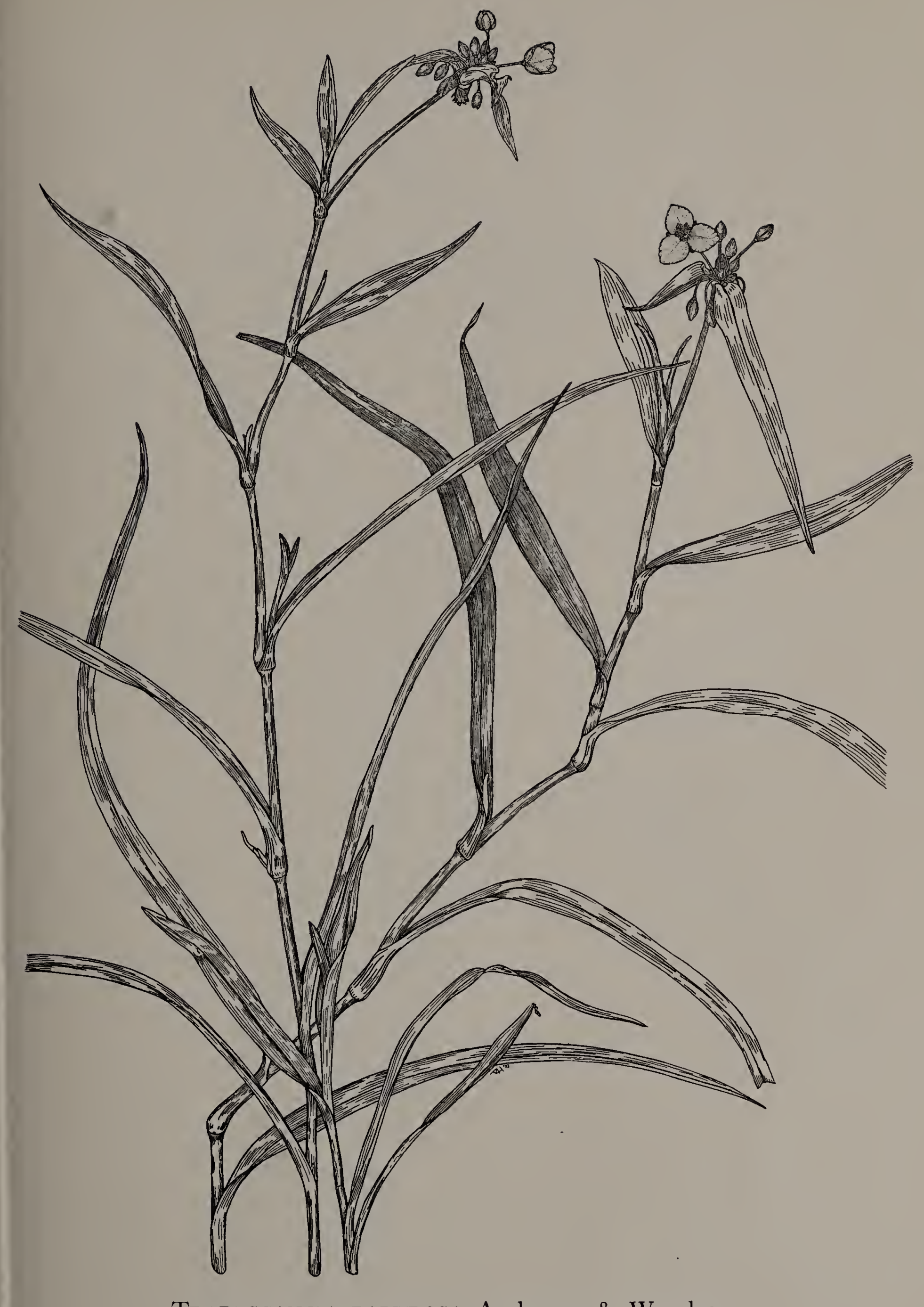

Tradescantia paludosa Anderson \& Woodson. 



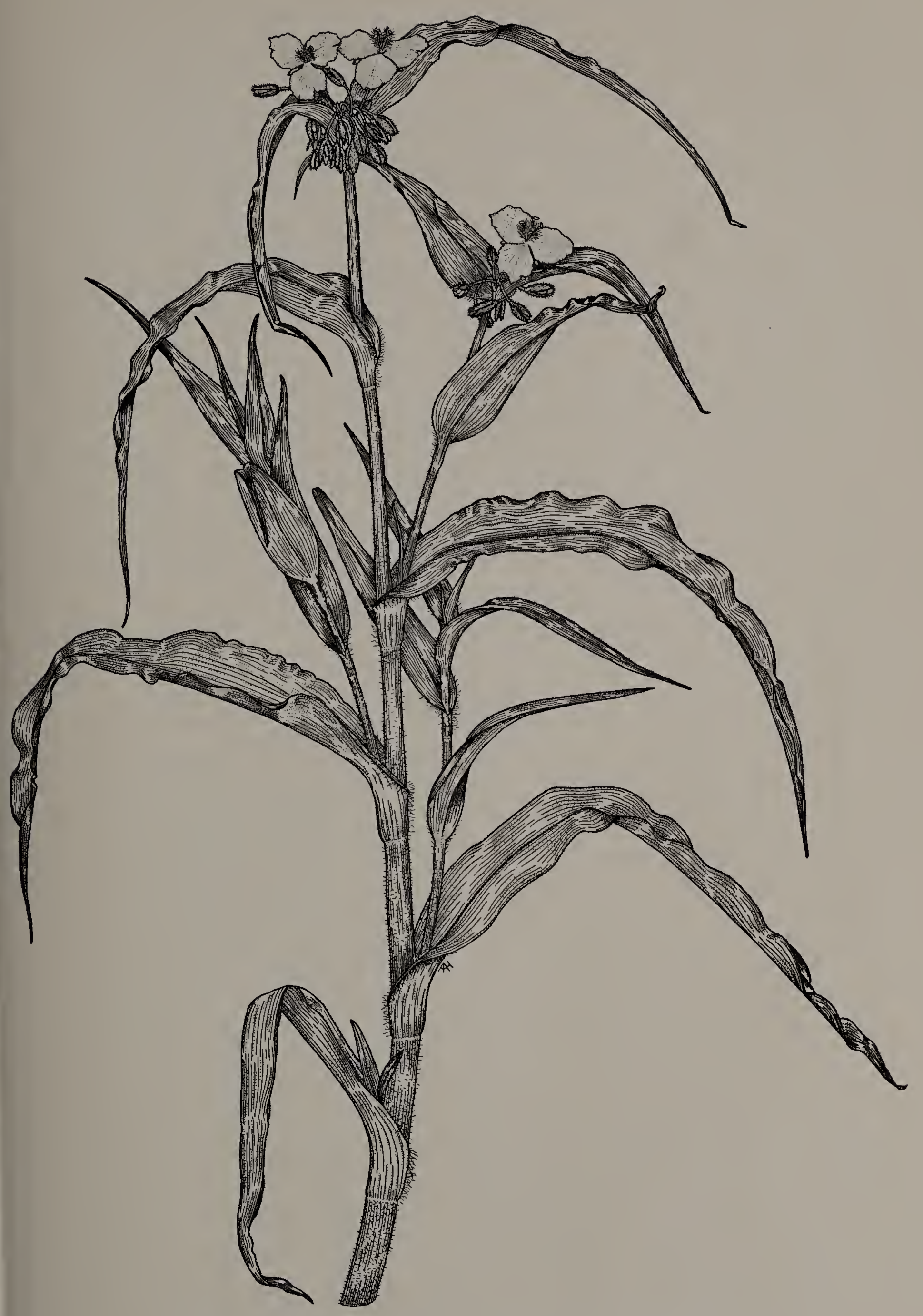

Tradescantia ozarkana Anderson \& Woodson. 

PUBLICATIONS PREPARED AT THE ARNOLD ARBORETUM

Of the following publications, the first and fifth can be obtained from the Arnold Arboretum, the second and third from Houghton Mifflin ComPANY, Boston and New York, and the fourth from the Macm Illan Company, New York.

The Silva of North America; A Description of the Trees which grow naturally in North America exclusive of Mexico. By Charles Sprague Sargent. With 740 plates drawn from nature by Charles Edward Faxon. 14 vols. $f^{\circ}$. Boston and New York, 1891-1902. Price $\$ 350.00$ The same. Broken sets. Number of volumes and prices on request. Complete sets of the 740 plates drawn for the "Silva." Price $\$ 100.00$ Selected plates (according to number selected)

Price each $\$ 0.50$ to $\$ 1.00$

TREES AND ShruBS. Illustrations of new or little known ligneous plants. Prepared chiefly from material at the Arnold Arboretum and edited by Charles Sprague Sargent. With 200 plates drawn by Charles Edward Faxon. 2 vols. $f^{\circ}$. Boston, 1905-1913.

Price $\$ 40.00$

A Manual of the Trees of North America exclusive of Mexico. By Charles Sprague Sargent. With 783 illustrations from drawings by Charles Edward Faxon and Mary W. Gill. Second edition reprinted with corrections. 910 pp. $8^{\circ}$. Boston and New York, 1926.

Price $\$ 5.00$

Manual of Cultivated Trees and Shrubs Hardy in North America exclusive of Subtropical and Warmer Temperate Regions. By Alfred Rehder. $37+930$ pp. $8^{\circ}$. New York, 1927.

Price $\$ 5.00$

Corrections and Emendations of Rehder's Manual of Cultivated Trees and Shrubs. By Alfred Rehder. 19 pp. 1935.

Price $\$ 0.10$

\section{COLLECTIONS OF PHOTOGRAPHS TAKEN BY E. H. WILSON}

THESE pictures represent trees and shrubs and different types of vegetation found in eastern Asia, Africa, India and in Australasia; they have been taken by Wilson with a full knowledge of his subjects and their scientific importance. They may be obtained from the Arnold Arboretum, Jamaica Plain, Mass.

\section{Chinese Photographs taken 1907-1910}

Series 1. 500 photographs (each $81 / 2 \times 61 / 2$ inches) taken 1907-1909, with typewritten index

Price $\$ 250.00$

Series 2. 350 photographs (size as above, numbered 01-0350) taken 1910, with typewritten index

Price $\$ 175.00$

\section{Japanese Photographs taken 1914}

A series of 600 photographs (size as above, numbered $x 1-x 600$ ) with typewritten index

Price $\$ 300.00$

Photographs of the Expedition to Eastern Asia 1917-1918

A series of 700 photographs (size as above, numbered N 1-N 700) with typewritten index

Price $\$ 350.00$

This series consists of the following sets: Liukiu Islands (60 photographs) Price $\$ 30.00$.-Bonin Islands (30 photographs) Price $\$ 15.00$.Japan (50 photographs) Price $\$ 25.00$ - - Korea (310 photographs) Price $\$ 155.00$. - Formosa (250 photographs) Price $\$ 125.00$.

Photographs of the Expedition to Australasia, Indo-Malaya and AfricA, 1920-1922

A series of 522 photographs (size as above, numbered y 1-y 522) with typewritten index

Price $\$ 261.00$

This series consists of the following sets: Australasia (245 photographs) Price $\$ 123.00$. - Indo-Malaya (93 photographs) Price $\$ 47.00$.Africa (184 photographs) Price $\$ 92.00$.

Postage not included in the prices quoted above.

Selections from these photographs will be furnished at an advanced price. 


\section{PUBLICATIONS OF THE ARNOLD ARBORETUM}

The following publications can be obtained from the ArNold ARBoswomy Jamaica Plain, Mass.

The Bradley Bibliography. A guide to the literature of woody plants, including books and articles in the proceedings of learned societies and in scientific and popular journals, published in all languages to the end of the nineteenth century. Compiled under the direction of Charles Sprague Sargent by Alfred Rehder. $4^{\circ}$. 5 vols. Cambridge, 1911-1918.

Bound Price $\$ 40.00$

Unbound Price $\$ 30.00$

The Genus Pinus. By George Russell Shaw. f․ 96 pp. 39 pl. Cambridge, 1914.

Price $\$ 10.00$

Catalogue of the Library of the Arnold Arboretum. Compiled undethe direction of Charles Sprague Sargent by Ethelyn Maria Tucker. $f^{\circ} .2$ vols. Cambridge, 1914-1917.

Vol. I. Serial publications-Authors and titles. Unbound Price $\$ 7.50$

Vol. II. Subject catalogue. “ Price $\$ 7.50$

Vol. III. Authors and titles. Supplement 1917-1933. Bound Price $\$ 10.00$

Unbound Price $\$ 8.50$

The Conifers and Taxads of Japan. By Ernest Henry Wilson. 4* 91 pp. 59 pl. Cambridge, 1916.

Price $\$ 5.00$

The Forest Trees of New England. By Robert Greenleaf Leavit. viii +179 pp. 1 pl. 2 maps, $78+1$ figs. sm. $8^{\circ}$. Jamaica Plain, Mass., 1932

Postage not included in the prices quoted above.

Price $\$ 2.00$

Through the Arnold Arboretum. $8^{\circ} .48$ pp. 16 ill. 1 map. Price $\$ 0.2^{2}$

De Luxe edition. Price $\$ 0.50$

Journal of the Arnold Arboretum. A quarterly journal published by the Arnold Arboretum. Subscription $\$ 4.00$ per year. Price of single copie: $\$ 1.25$. Back numbers on hand of Vols. VI-XIII except No. 3 of Vol. X.

Bulletin of Popular Information, Series 3, illustrated. Issued during spring and autumn, about 12 numbers per year, together with index and title page. Subscription $\$ 1.00$ per annum.

A limited number of series 2, Vols. I-II (1915-16), VII (1921), X-Xat (1924-26), and of Series 3, Vols. I-VII (1927-33) can be obtained at $\$ 1.0$ each.

Reprints from the Journal of the Arnold Arboretum:

Northern Trees in Southern Lands. By Ernest H. Wilson. 20 pe 1923.

Price $\$ \mathrm{~J}$.00

Enumeration of the Ligneous Plants of Northern China. By Ajfred Rehder.-Parts I-III (Ginkgoaceae to Sapindaceae) $76+88+77$ 1 pl. 1923-26.

Price का.'?

Corrections and Emendations of the Second Edition of Sargero? Manual of the Trees of North America. By C. S. Sargent. 21 pp 1926.

Price solio

The Spontaneous Flora of the Arnold Arboretum. By Ernest I. Palmer. 57 pp. 1 pl. 1930.

Price \$0 511

Contributions to the Flora of the New Hebrides; Plants Colizetia BX S. F. KaJEwski in 1928 And 1929. By A. Guillaumin. 118 pp. 5 fie: 1 pl. 1931-1932. 

